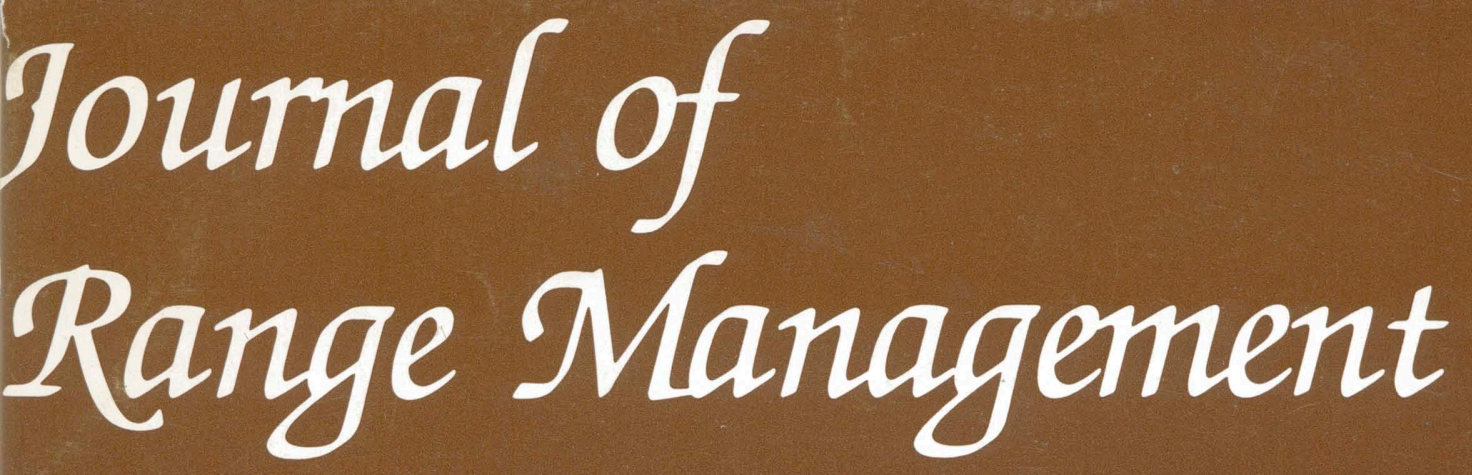

TABLE OF CONTENTS: VOL. 54, NO. 6, November 2001

FEATURE ARTICLE

630 Adoption of Brush Busters: Results of Texas county extension survey by Urs

P. Kreuter, Heidi E. Amestoy, Darrell N. Ueckert, and W. Allan McGinty

Grazing Management

640 Nutritional dynamics of 7 northern Great Basin grasses by Dave Ganskopp and Dave Bohnert

648 Influence of off-stream supplements on streambanks of riparian pastures by Michael L. McInnis and James McIver

Measurement/Sampling

653 Frequency grid-a simple tool for measuring grassland establishment by Kenneth P. Vogel and Robert A. Masters

Plant/Animal

656 Suppression of annual bromes impacts rangeland: Vegetation responses by Marshall R. Haferkamp, R.K. Heitschmidt, Elaine E. Grings, Michael D. MacNeil, and Michael G. Karl

663 Suppression of annual bromes impacts rangeland: Animal responses by Marshall R. Haferkamp, Elaine E. Grings, R.K. Heitschmidt, Michael D. MacNeil, and Michael G. Karl

Plant Ecology

669 Chemical composition and livestock ingestion of carob (Ceratonia siliqua L.) seeds by Moh'd Khair J. El-Shatnawi, and Khalil I. Ereifej

674 Adaptation of perennial triticeae to the eastern Central Great Plains by Kenneth P. Vogel and Kevin J. Jensen

680 Mesquite and grass interference with establishing redberry juniper seedlings by W.R. Teague, S.L. Dowhower, S.G. Whisenant, and E. FloresAncira

685 Effects of prescribed fire on sand shinnery oak communities by Wade C. Harrell, Samuel D. Fuhlendorf, and Terrence G. Bidwell

691 Juniper encroachment into aspen in the Northwest Great Basin by Travis G. Wall, Richard F. Miller, and Tony J. Svejcar

699 Climatic influences on recruitment of 3 subspecies of Artemisia tridentata by Aaron M. Maier, Barry L. Perryman, Richard A. Olson, and Ann L. Hild 
Published bimonthly_January, March, May, July, September, November

Copyright 2001 by the Society for Range Management

INDIVIDUAL SUBSCRIPTION is by membership in the Society for Range Management.

LIBRARY or other INSTITUTIONAL SUBSCRIP. TIONS on a calendar year basis are $\$ 95.00$ for the United States postpaid and $\$ 112.00$ for other countries, postpaid. Payment from outside the United States should be remitted in US dollars by international money order or draft on a New York bank.

BUSINESS CORRESPONDENCE, concerning subscriptions, advertising, reprints, back issues, and related matters, should be addressed to the Managing Editor, 445 Union Blvd., Suite 230, Lakewood, Colorado 80228.

EDITORIAL CORRESPONDENCE, concerning manuscripts or other editorial matters, should be addressed to the Editor, Gary Frasier, 7820 Stag Hollow Road, Loveland, Colorado 80538. Page proofs should be returned to the Production Editor, 3059A Hwy 92, Hotchkiss, CO 81419-9548.

INSTRUCTIONS FOR AUTHORS appear on the inside back cover of most issues. THE JOURNAL OF RANGE MANAGEMENT (ISSN 0022-409X) is published bimonthly for $\$ 56.00$ per year by the Society for Range Management, 445 Union Blvd. Ste 230, Lakewood, Colorado 80228. SECOND CLASS POSTAGE paid at Denver, Colorado and additional offices.

POSTMASTER: Return entire journal with address change-Address Service Requested to Society for Range Management, 445 Union Blvd., Suite 230, Lakewood, Colorado 80228.

\section{PRINTED IN USA}

Editor-In-Chief

SAM ALBRECHT

445 Union Blvd., Ste 230

Lakewood, Colorado 80228

(303) 986-3309

Fax: (303) 986-3892

e-mail address:

sam_albrecht@ix.netcom.com

\section{Editor/Copy Editor}

GARY FRASIER/JO FRASIER

7820 Stag Hollow Road

Loveland, Colorado 80538

e-mail address:

gfrasier@lamar.colostate.edu

Production Editor

PATTY RICH

Society for Range Management

3059A Hwy 92

Hotchkiss, Colorado 81419-9548

e-mail address:

prich@starband.net

\section{Book Review Editor}

DAVID L. SCARNECCHIA

Dept of Natural Res. Sci.

Washington State University

Pullman, Washington 99164-6410

e-mail address:

scarneda@mail.wsu.edu

Electronic JRM Editor

M. KEITH OWENS

Texas A\&M University

Research Center

1619 Garner Field Road

Ulvade, Texas

e-mail address:

m-owens@tamu.edu
Soils

704 Grazing impacts on soil nitrogen and phosphorus under Parkland pastures by V.S. Baron, A.C. Dick, E. Mapfumo, S.S. Malhi, M.A. Naeth, and D.S. Chanasyk

711 Tracked vehicle impacts to vegetatation structure and soil erodibility by William P. Grantham, Edward F. Redente, Calvin F. Bagley, and Mark W. Paschke

Reclamation

717 Long-term plant community development as influenced by revegetation techniques by Gregory J. Newman and Edward F. Redente

Book Reviews

725 The View From Bald Hill: Thirty Years in an Arizona Grassland. by Carl E. Bock and Jane H. Bock

Indexes

726 JRM Table of Contents, Vol. 54, 2001

727 JRM Index, Volume 54, 2001
MICHAEL H. RALPHS

USDA-ARS

Poisonous Plant Lab

1150 E $1400 \mathrm{~N}$

Logan, Utah 84341-2881

Miles City, Montana 59301

USDA-ARS

920 Valley Road

Reno, Nevada 89512

KLAAS BROERSMA

Agriculture and Agri-Food Canada 3015 Ord Rd.

Kamloops, British Columbia

V2B 8A9 CANADA

JOE E. BRUMMER

Mt. Meadows Res. Ctr.

P.O. Box 598

Gunnison, Colorado 81230

DAVID GANSKOPP

USDA-ARS

HC-71 4.51 HWY 205

Burns, Oregon 97720

ROBERT GILLEN

USDA-ARS

Southern Plains Range Res. Sta.

2000 18th Street

Woodward, Oklahoma 73801
MARSHALL HAFERKAMP

USDA-ARS

Fort Keogh-LARRL

Route 1, Box 2021

Miles City, Montana 59301

CAROLYN HULL SIEG

S.W. Science Complex

2500 South Pine Knoll

Flagstaff, Arizona 86001

FAISAL K. TAHA

Director of Technical Programs

Biosaline Agriculture Center

P.O. Box 14660

Dubai, U.A.E.

\section{ALLEN TORELL}

New Mexico State University

Agricultural Economics

Box 3169

Las Cruces, New Mexico 88003

PAUL OHLENBUSCH

Kansas State University

Department of Agronomy

Throckmorton Hall

Manhattan, Kansas 66506

MIMI WILLIAMS

USDA-ARS

22271 Chinsegut Hill Rd

Brooksville, Florida 34601-4672

\section{ROBERT PEARCE}

Shepherd Miller, Inc.

311 Vista Road

Bishop, California 93514 


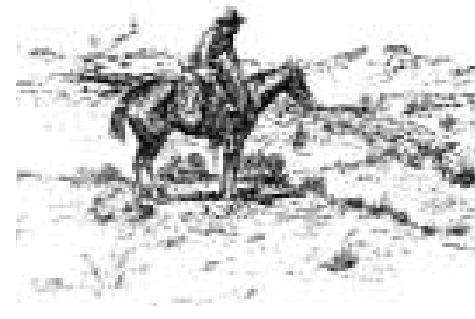

President

JAMES T. O'ROURKE

Chadron State College

61 Country Club Road

Chadron, Nebraska 69337

1st Vice-President

RODNEY K. HEITSCHMIDT

USDA-ARS

Ft. Keogh LARRL

Rt 1, Box 2021

Miles City, Montana 59301-9801

\section{2nd Vice-President \\ BOB BUDD \\ Red Canyon Ranch \\ 350 Red Canyon Rd \\ Lander, Wyoming 82520-9417 \\ Executive Vice-President \\ SAM ALBRECHT \\ 445 Union Blvd. Suite 230 \\ Lakewood, Colorado 80228-1259 \\ (303) 986-3309 \\ Fax: (303) 986-3892 \\ e-mail address: \\ sam_albrecht@ix.netcom.com}

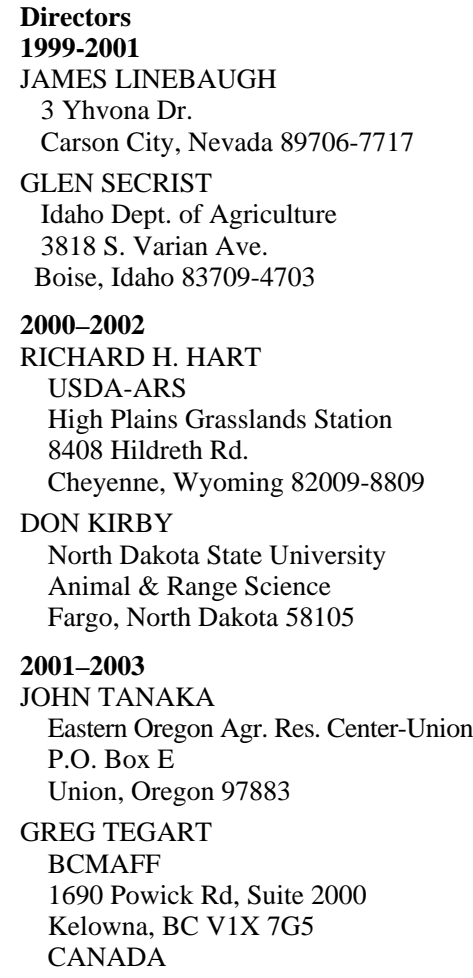

The term of office of all elected officers and directors begins in February of each year during the Society's Annual Meeting.
The Society For Range Management, founded in 1948 as the American Society of Range Management, is a nonprofit association incorporated under the laws of the State of Wyoming. It is recognized exempt from Federal income tax, as a scientific and educational organization, under the provisions of Section 501(c)(3) of the Internal Revenue Code, and also is classed as a public foundation as described in Section 509(a)(2) of the Code. The name of the Society was changed in 1971 by amendment of the Articles of Incorporation.

The objectives for which the corporation is established are:

-to properly take care of the basic rangeland resources of soil, plants, and water;

-to develop an understanding of range ecosystems and of the principles applicable to the management of range resources;

— to assist all who work with range resources to keep abreast of new findings and techniques in the science and art of range management;

-to improve the effectiveness of range management to obtain from range resources the products and values necessary for man's welfare;

-to create a public appreciation of the economic and social benefits to be obtained from the range environment;

- to promote professional development of its members.

Membership in the Society for Range Management is open to anyone engaged in or interested in any aspect of the study, management, or use of rangelands. Please contact the Executive VicePresident for details.

The Journal of Range Management is a publication of the Society for Range Management. It serves as a forum for the presentation and discussion of facts, ideas, and philosophies pertaining to the study, management, and use of rangelands and their several resources. Accordingly, all material published herein is signed and reflects the individual views of the authors and is not necessarily an official position of the Society. Manuscripts from anyone-nonmembers as well as members-are welcome and will be given every consideration by the editors. Editorial comments by an individual are also welcome and, subject to acceptance by the editor, will be published as a "Viewpoint."

In Cooperation With: Some of the articles appearing in The Journal of Range Management (JRM) are presented in cooperation with The American Forage and Grassland Council (AFGC). This cooperation consists of $J R M$ acceptance of professional papers in forage grazing management and related subject areas from AFGC members and the appointment of 2 AFGC affiliated associate editors to JRM's Editorial Staff. The American Forage and Grassland

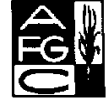
Council Offices: P.O. Box 94, Georgetown, Texas 78627; Larry Jeffries, President; Dana Tucker, Executive Secretary.

Contribution Policy: The Society for Range Management may accept donations of real and/or personal property subject to limitations set forth by State and Federal law. All donations shall be subject to management by the Executive Vice President as directed by the Board of Directors and their discretion in establishing and maintaining trusts, memorials, scholarships, or other types of funds. Individual endowments for designated purposes can be established according to Society policies. Gifts, bequests, legacies, devises, or donations not intended for establishing designated endowments will be deposited into the SRM Endowment Fund. Donations or requests for further information on Society policies can be directed to the Society for Range Management, Executive Vice-President, 445 Union Blvd., Suite 230, Lakewood, Colo. 80228-1259. We recommend that donors consult Tax Advisors in regard to any tax consideration that may result from any donation. 


\title{
Adoption of Brush Busters: Results of Texas county exten- sion survey
}

\author{
URS P. KREUTER, HEIDI E. AMESTOY, DARRELL N. UECKERT, AND W. ALLAN MCGINTY
}

Authors are assistant professor and graduate research assistant, Dept. of Rangeland Ecology and Management, Texas A\&M University, College Station, Tex. 77843; professor, Texas Agr. Exp. Sta., US Hwy. 87 North, San Angelo, Tex. 76901; and professor, Texas Agr. Ext. Service, US Hwy. 87 North, San Angelo, Tex. 76901

Abstract

Changing landowner demographics and the increasing recognition that some quantity of woody plants is valuable for certain rangeland management objectives has led to increasing interest in selective brush management practices. Brush Busters is a collaborative extension/research program developed in response to this growing interest. A survey of Texas County Extension Agents-Agriculture was conducted in 1999 to determine their perceptions about the interest in and adoption of Brush Busters practices. Using 3 threshold photographs, Extension Agents representing almost $50 \%$ of the counties in the 9 Extension Districts surveyed estimated that 44,34 , and $49 \%$ of the total area of mesquite, juniper and pricklypear, respectively, could be treated using Brush Busters. They also indicated that over 405,000 ha (78\% mesquite) were treated with Brush Busters methods between 1995 and 1998, but that this represented less than $7 \%$ of the potentially treatable area. In most Extension Districts, more time was spent disseminating information about Brush Busters methods than any other brush management method since 1995. Extension Agents indicated that Brush Busters has become popular because it is perceived to be an inexpensive, convenient, safe, effective and predictable method for controlling brush, and because user-friendly information is widely available. Our findings suggest that increasing the adoption rates of ecologically sound rangeland management technologies requires: (1) greater emphasis on developing and disseminating user-friendly messages to rangeland managers and Extension Agents; and (2) greater emphasis on short-term efficacy rather than the long term advantages of new technologies.

Key Words: agency and industry partnerships, brush management, collaborative marketing, information dissemination, technology adoption

The assumption that ranchers are profit maximizers and that good managers can adopt technology are common among technology developers (White 1987, Workman 1986). However, the adoption of new technology by land managers is affected by many factors other than productivity including perceived risk and uncertainty (Zepada 1994). Fliegel (1993) proposed a technology adoption model for land managers in which the interaction of community characteristics (age, education, income, size of farm

Research was funded through a gift from Dow AgroSciences LLC and a Texas A\&M University Faculty Mini-Grant.

Manuscript accepted 3 Feb. 2001.

\section{Resumen}

El cambio demográfico de la propiedad de la tierra y el mayor reconocimiento de que alguna cantidad de plantas leñosas es valiosa para ciertos objetivos de manejo de pastizales ha conducido a aumentar el interés de practicas selectivas de manejo de arbustos. Los Quebradores de Arbustos es un programa colaborativo de extensión/investigación desarrollado en respuesta de este creciente interés. En 1999 se condujo un muestreo entre los agentes agrícolas municipales de extensión de Texas para determinar sus percepciones acerca del interés en y la adopción de prácticas de quebrado de arbustos. Utilizando 3 fotografías de umbral, los Agentes de Extensión representaron casi el 50\% de los municipios en los 9 Distritos de Extensión muestreados, estimando que 44, 34 y 49\% del área total de "Mesquite", "Juniper" y "Pricklypear", respectivamente, pudieran ser tratados utilizando quebradores de arbustos. Ellos también indicaron que entre 1995 y 1998 más de 405,000 ha (78\% "Mesquite") fueron tratadas con métodos de quebrado de arbustos, pero que esta superficie representó menos del $7 \%$ del área potencialmente tratable. Desde 1995, en la mayoría de los Distritos de Extensión, se gastó mas tiempo diseminando información acerca de los métodos de quebrado de arbustos que cualquier otro método de manejo de arbustos. Los agentes de extensión indicaron que los quebradores de arbustos han venido a ser más populares porque se percibe que es un método barato, conveniente, seguro, efectivo y predecible para controlar arbustos, y porque hay disponible mucha información de fácil comprensión respecto a ellos. Nuestros hallazgos sugieren que para incrementar las tasas de adopción de tecnologías que facilitan el manejo de los pastizales con sentido ecológico se necesita: (1) un mayor esfuerzo en desarrollar y diseminar mensajes de fácil comprensión para los manejadores de pastizales y Agentes de Extensión y (2) Se debe enfatizar en la eficacia de las nuevas tecnologías a corto plazo en lugar de las ventajas a largo plazo.

and tenure status) social participation in farm and/or community organizations, and communication factors (extension contact, print media contact, and radio contact) affect the rate of technology adoption. Yet, Barao (1992) pointed out that psychological and behavioral aspects of technology adoption are often less tangible than physical or economic constraints to technology adoption. For example, while it is often assumed that level of education positively impacts the rate of adoption of new technology, Rowan and White (1994) did not find this relationship in a survey of Texas ranchers. A 1989 survey of South Texas Ranchers, identified range condition, forage quantity, and past experience as being the most important factors affecting decisions about live- 
stock stocking rates, while economics was moderately important and agency personnel and neighbors were generally of low importance (Hanselka et al. 1991).

Rowan et al. (1994) found that land managers' decisions about adopting weed and brush management technologies were often negatively affected by neighbors' attitudes and fear of treatment methods, especially the use of fire. They also found that the amount of brush control was negatively correlated with the proportion of offranch income but positively correlated with the proportional income from livestock. In addition, Hanselka et al. (1990) reported that quality and quantity of herbage production, amount of rainfall (which affects the success of weed and brush control treatments), livestock management considerations, and projected economic efficacy were major factors affecting landowners' decisions about initiating weed and brush management. Once the decision is made to implement a treatment, factors influencing which weed or brush management technique is to be used include, plant community structure, plant size and density, treatment costs, projected economic returns, and personal experience.

Intensified livestock grazing and reduced fire frequency on US rangelands has resulted in a change in the grasswoody plant interaction (Scifres 1980, Archer and Stokes 2000), which has led to widespread transformation of grasslands to shrublands, savannas and woodlands (Archer 1989, 1994, Schlessinger et al. 1990), and a decline in water yield from rangelands (Douglass 1983, Jofre and Randal 1993, Thurow et al. 2000). The resulting decline in rangeland productivity has led to significant investment in brush removal on US rangelands, especially since the 1960s (Bovey 1998). However, since the 1980s, increasing recognition of the potential value of some quantity of woody plants on rangelands has resulted in increasing emphasis on the use of integrated brush management systems to achieve diverse management goals (Scifres et al. 1983, Hanselka et al. 1996). While there has been a shift in brush control emphasis, economic analyses of alternative brush management practices have, with few exceptions (Kreuter et al. 1996), ignored the opportunity cost of not controlling brush (Teague et al. 2001, Kreuter et al. 1999). The increasing interest since the mid-1980s in wildlife as a source of revenue on Texas rangelands has led to a greater focus on more selective, and less costly brush management techniques that enhance wildlife habitat (see for example Fulbright 1997).
One such program is Brush Busters which was developed in 1995 as a collaborative program of the Texas Agricultural Experiment Station (TAES) and the Texas Agricultural Extension Service (TAEX) at San Angelo. The purpose of this program was to expedite the adoption of select "individual plant treatments" (IPT) for controlling brush by using environmentally friendly herbicides, and by targeting younger, more susceptible plants in order to increase the effectiveness and decrease the cost of herbicide applications (Ueckert 1997, Ueckert et al. 1999). Specific Brush Busters programs have been developed for mesquite (Prosopis glandulosa Torr.) in 1995, juniper (Juniperus ashei Buchh. and J. pinchotii Sudw.) in 1996, prickly pear (Opuntia spp.) and other cactus species in 1997, and for huisache (Acacia smalii (L.) Willd.) in 2000. To date, Brush Busters has received wide interest among Texas landowners, but the specific reasons for its popularity have not been explicitly addressed. The high adoption rate of the Brush Busters approach to IPT provides a timely opportunity to identify those factors that enhance the adoption of technologies aimed at improving rangeland conditions.

In the summer of 1999 , we conducted a survey of TAEX County Agricultural Extension Agents-Agriculture to take advantage of this opportunity. The objectives of the study were: (1) to obtain general information about brush management in Texas; (2) to estimate the area in Texas of mesquite, juniper, and pricklypear potentially treatable with Brush Busters methods; and (3) to determine Extension Agents' perceptions about the level of adoption of Brush Busters by landowners relative to other brush management practices, and the factors affecting landowners' interests in this approach to brush management. This paper reports the survey result from which we were able to draw conclusions not only about the potential for individual plant brush control in Texas, but also about the lessons that Brush Busters provides for the adoption of other rangeland management practices.

\section{Methodology}

The objectives of the study were achieved through the analysis of survey data obtained from County Extension Agents-Agriculture (hereafter referred to as Extension Agents) throughout Texas. A self-completion mail survey questionnaire was used to gather information about the county, extension-related activities, general brush management issues in each respondent's county, and about the use of Brush Busters. Three photographic images showing threshold conditions for mesquite, juniper and pricklypear were appended to the questionnaire to provide survey participants the same point of reference in answering questions about the density of these 3 species. The threshold conditions were based on estimated maximum plant height and/or plant density that is treatable using Brush Busters.

The survey questionnaire was mailed in April 1999 to 250 Extension Agents serving all 254 Texas Counties. The survey was administered using the multiple follow-up procedures of the "Total Design Method" popularized by Dillman (1978). The 4-stage procedure consisted of: (1) Day 1 - mail questionnaire and cover letter explaining the purpose of the survey; (2) Day 10 - mail reminder card to nonrespondents; (3) Day 21 - mail reminder letter with a second copy of the questionnaire to non-respondents; and (4) Day 28, mail final reminder card.

To compare data from different parts of the State, counties were categorized according to the 12 Texas Agricultural Extension Districts. Numerous Extension Agents from counties east of Highway I35 reported that mesquite, juniper, and pricklypear management was not applicable in their areas. Because our survey focused on the management of brush species that have been incorporated into Brush Busters by 1999, we excluded the counties in the North, East, and Southeast Extension Districts from the analysis. A total of 192 counties in the remaining 9 Extension Districts were thus included in the analysis.

In a few areas of inquiry, some the Extension Agents were internally inconsistent in answering replicate questions. We excluded from the analysis responses to replicate questions that differed by more than $10 \%$ because of uncertainty about which response was correct. Thus the sample size (n) was not constant for all the areas of inquiry. Simple descriptive statistics were used to compare data from the Extension Districts.

\section{Results}

Of the 192 Texas counties in the 9 Extension Districts included in the study (Fig.1), we received 164 responses. While the overall response rate was $85.4 \%$, response rates varied ranging from a high of $100 \%$ in the Southwest district, to a low of $68 \%$ in the Rolling Plains district. The results of the study are represented in 3 


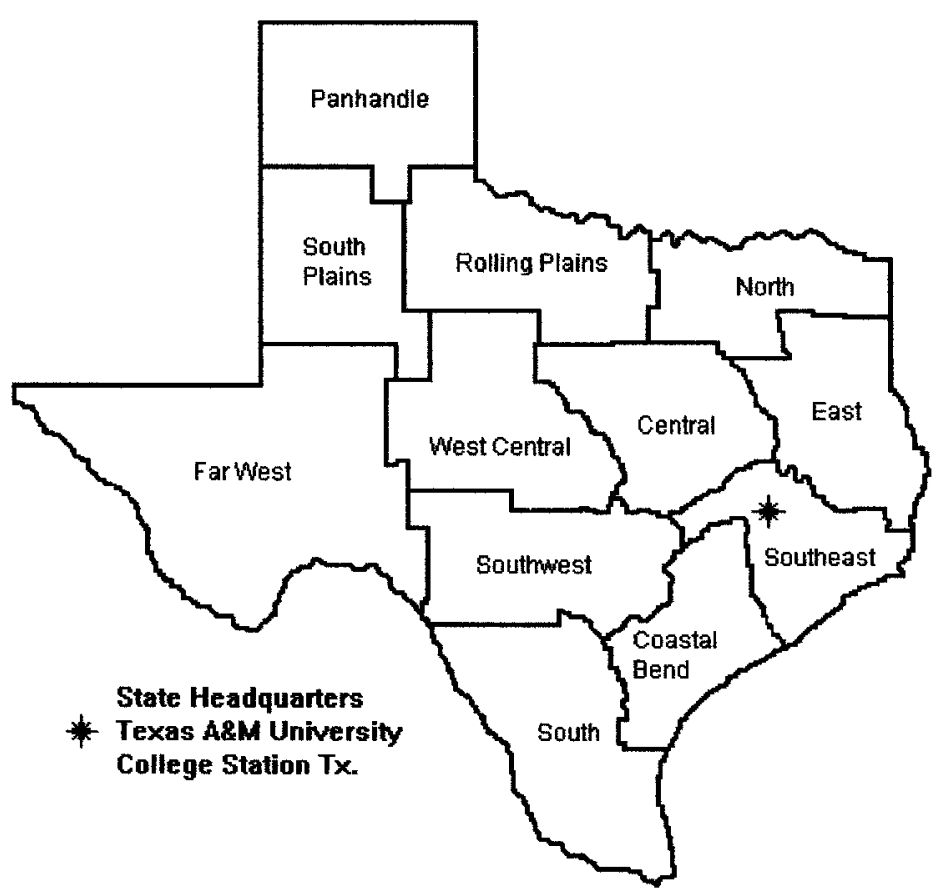

Fig. 1. Texas Agricultural Extension Districts

parts: (1) ranch demographic information, (2) general brush management, and (3) Brush Busters.

\section{Ranch Demographic Information}

Across all 9 Extension Districts included in the analysis, the greatest proportion of landholdings occurred in the 10 to 40ha $(34 \%)$ and 41 to 404 -ha $(33 \%)$ size categories. While the proportional representation in these size categories was substantially greater in the Central, Southwest, Coastal Bend, and South districts and lower in the Panhandle and Far West districts, the responding Extension Agents indicated that the number of ranches in these categories increased in all 9 districts since 1990. By contrast, ranches greater than 404 ha in size were proportionately fewer across all 9 Extension Districts $(405-1,215$ ha $=13 \%, 1,216-4,045$ ha $=$ $10 \%$, and $>4,045 \mathrm{ha}=10 \%$ ), except in the Far West district where ranches exceeding 4,045 ha were most numerous $(47 \%)$. In virtually every district the proportion of ranches greater than 405 ha in size has decreased over the last 10 years. This demographic shift towards landholdings of less than 405 ha suggests a potential overall shift in land use and management objectives. For example, based on anecdotal information about the amount of time spent by Extension Agents in disseminating rangeland-related information, the decline in the size of landholdings appears to be associated with a shift in management emphasis from livestock to wildlife in the Edwards Plateau and South Texas burning, aerial herbicide applications, biological methods, and other treatments. In each Extension District, we then ranked the average time spent on each of the 7 brush management categories; 1 and 7 being assigned to the categories to which the most and least amount of time was allocated, respectively. In all but 2 of the 9 Extension Districts analyzed (South Plains and Coastal Bend) most time was spent on disseminating information about Brush Busters methods. There was greater variation in the proportional amount of time spent disseminating information about other brush management methods. Across all 9 Extension Districts, the average rank values for brush treatment methods were: 1.3 for Brush Busters, 2.2 for other IPTs, 3.2 for mechanical treatments, 4.3 for prescribed burning, 4.8 for aerial herbicide applications, 5.8 for biological methods, and 6.3 for other treatments.

Extension Agents were subsequently asked to rank their perceptions of the interest among landowners in various brush control techniques (Fig. 2), and to indicate how interest in these techniques have changed since 1995. Although, on average, the Extension Agents did not perceive there to be a strong interest (i.e., > 4) by landowners in any brush control technique, the survey did indicate above average interest in Brush Busters for all 3 species, and somewhat above average interest in dozing/grubbing for mesquite and juniper, and average interest in prescribed burning for all 3 species. Mean values of $>4$ (i.e., above average-to-great landowner interest) were recorded for the

\section{General Brush Management}

Extension Agents were asked to indicate the amount of time that they spend disseminating information about Brush Busters, other individual plant treatments (IPT), mechanical treatments, prescribed
Plains areas (West Central, Southwest, and implications for rangeland ma practices implemented by landowners, including brush management.

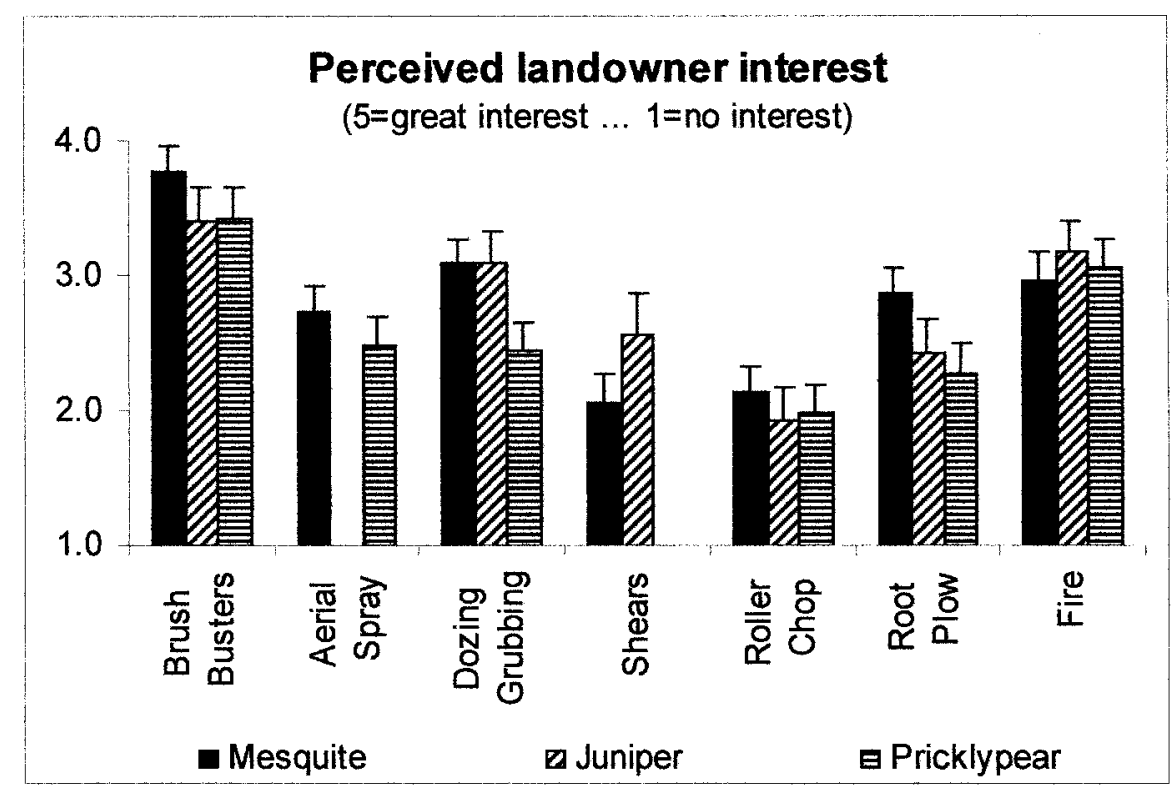

Fig. 2. Average of Extension Agents' perceptions regarding landowners' interests in various brush control techniques. (Data dispersion bars represent $95 \%$ confidence limits.) 

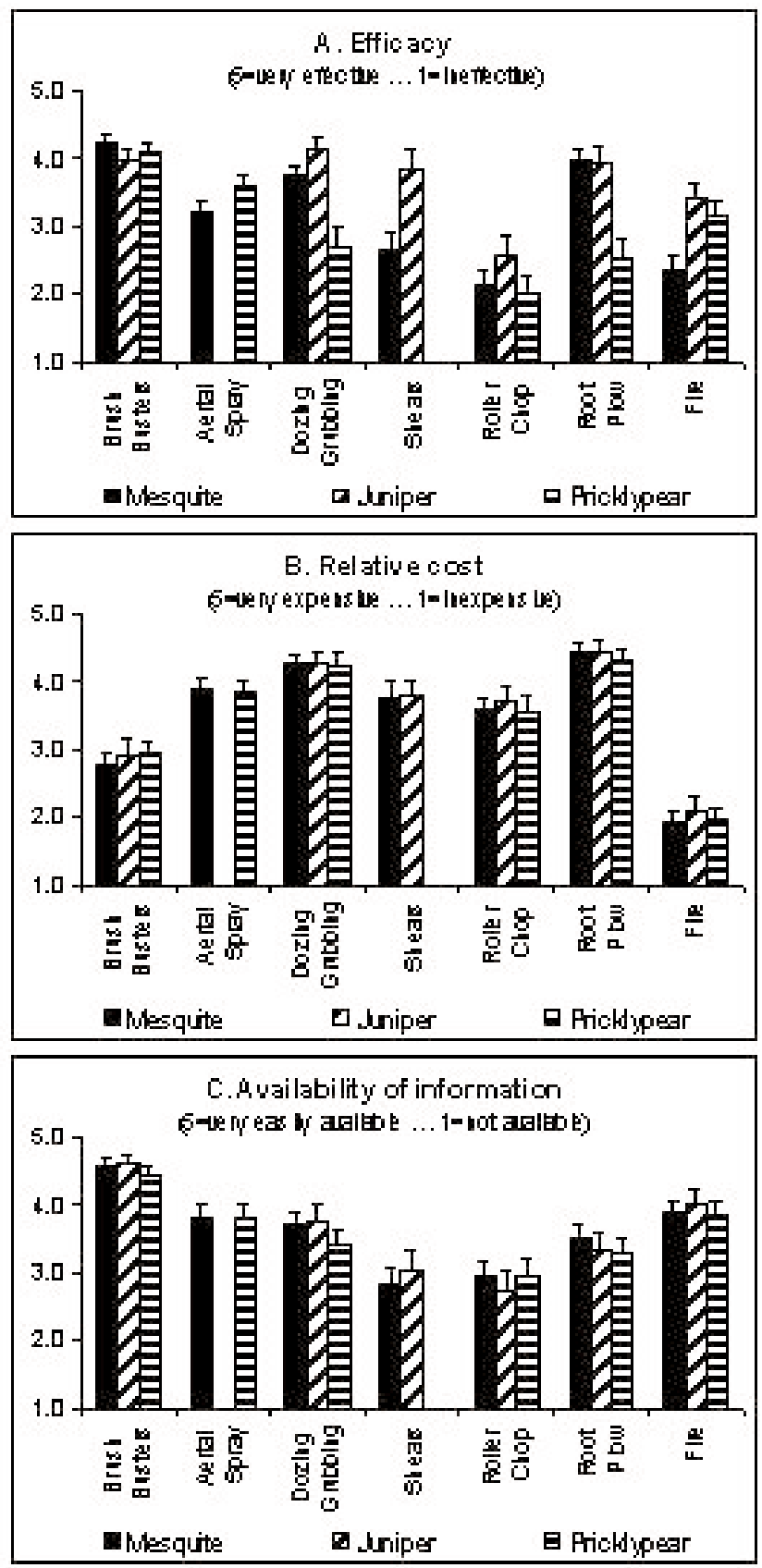

Fig. 3. Perceived comparative efficacy, cost effectiveness, and availability of information about specific brush control techniques for mesquite, juniper, and pricklypear. (Data dispersion bars represent $95 \%$ confidence limits.)

use of Brush Busters on all 3 species in the West Central Extension Districts, and for the use of Brush Busters for mesquite and juniper in the Central Extension District. The other treatment types were, almost without exception, valued at $<4$ (and in many cases at $<3$, i.e., below average interest) in virtually all Extension Districts. However, on average, Extension Agents also reported that there has been an increase in landowner interest in Brush Busters and the use of prescribed fire for controlling all 3 species, as well as in the use of dozing/grubbing, hydraulic shears, and root plowing for controlling juniper.

In the same series of questions about various types of brush management, Extension Agents were also asked to rank on a scale of 1 to 5 their impressions about the efficacy, cost effectiveness, and availability of information on specific brush control techniques (Fig. 3). On average, the Extension Agents ranked Brush Busters as high or higher in terms of effi- cacy than any other brush control technique for mesquite and prickly pear, and almost as high as dozing/grubbing for juniper (Fig. 3, panel A). Root plowing was also considered to be effective for mesquite and juniper as was the use of hydraulic shears for juniper. Prescribed fire was considered to be of average efficacy for juniper and prickly pear. While hydraulic shears are an effective control method for $J$. ashei, this method is often ineffective for $J$. pinchotii unless the shearing is accompanied by herbicide treatment on the cut stump. The high rank value assigned to the hydraulic shears for juniper may be because Extension Agents addressed the question only in terms of $J$. ashei, which dominates in many areas, or it may reflect a lack of knowledge among the respondents about the resprouting characteristics of $J$. pinchotii when it is cut.

Extension Agents also considered Brush Busters to be substantially less expensive than the other treatment types, except fire, for all 3 species (Fig. 3, panel B). Combining efficacy and cost effectiveness, therefore, appears to place Brush Busters considerably ahead of alternative brush control techniques in the eyes of the Extension Agents, especially for mesquite.

They also indicated that information was more readily available about Brush Busters than other techniques, although information about prescribed fire also seemed to be readily available (Fig. 3, panel C).

\section{Brush Busters}

From the preceding results, it is apparent that Brush Busters has attracted considerable interest and, compared to other brush management approaches. It is positively regarded by many of the Extension Agents, in terms of its efficacy, relatively low cost, and availability of information.

The survey participants were asked to estimate the total area of mesquite, juniper and pricklypear in their county, and using 3 photographs that showed threshold vegetation conditions for the use of Brush Busters methods, to estimate the potential area suitable for Brush Busters applications in each county. The cumulative responses from the counties that submitted useable responses are presented in Table 1 , while the total size of each district and the combined area of the counties with useable responses are included in Table 2. The estimates provided by some Extension Agents were excluded from the analysis because of inconsistencies between 2 replicate questions. Thus, the number of counties $(\mathrm{N})$ used to derive the area esti- 
Table 1. Estimated total area of mesquite, juniper and pricklypear, and Brush Busters (BB) treatable area of each species.

\begin{tabular}{|c|c|c|c|c|c|c|c|c|c|}
\hline \multirow{3}{*}{ District name } & \multicolumn{3}{|c|}{ Mesquite } & \multicolumn{3}{|c|}{ Juniper } & \multicolumn{3}{|c|}{ Pricklypear } \\
\hline & \multirow{2}{*}{$\begin{array}{c}\text { Area } \\
\left(\text { ha } \times 10^{6}\right)\end{array}$} & \multicolumn{2}{|c|}{$\mathrm{BB}$ treatable } & \multirow{2}{*}{$\begin{array}{l}\text { Area } \\
\left(\text { ha } \times 10^{6}\right)\end{array}$} & \multicolumn{2}{|c|}{ BB treatable } & \multirow{2}{*}{$\begin{array}{c}\text { Area } \\
\left(\text { ha } \times 10^{6}\right)\end{array}$} & \multicolumn{2}{|c|}{ BB treatable } \\
\hline & & $\left(\right.$ ha $\left.\times 10^{6}\right)$ & $(\%$ total $)$ & & $\left(\right.$ ha $\left.\times 10^{6}\right)$ & $(\%$ total $)$ & & $\left(\right.$ ha $\left.\times 10^{6}\right)$ & $(\%$ total $)$ \\
\hline$\overline{\text { Panhandle }}$ & 0.624 & 0.463 & 74 & 0.204 & 0.107 & 52 & 0.315 & 0.261 & 83 \\
\hline South Plains & 0.619 & 0.342 & 55 & 0.194 & 0.137 & 71 & 0.301 & 0.248 & 83 \\
\hline Plains & 1.450 & 0.581 & 40 & 0.548 & 0.293 & 54 & 0.663 & 0.467 & 70 \\
\hline Far West & 2.306 & 1.221 & 53 & 0.747 & 0.223 & 30 & 0.726 & 0.407 & 56 \\
\hline Central & 0.608 & 0.273 & 45 & 0.505 & 0.117 & 23 & 0.217 & 0.075 & 35 \\
\hline West Central & 2.464 & 0.976 & 40 & 1.484 & 0.586 & 40 & 2.271 & 1.184 & 52 \\
\hline Southwest & 0.648 & 0.191 & 29 & 1.806 & 0.419 & 23 & 0.859 & 0.345 & 40 \\
\hline Coastal Bend & 0.150 & 0.089 & 59 & 0.005 & 0.005 & 100 & 0.074 & 0.037 & 50 \\
\hline South & 4.052 & 1.608 & 40 & 0 & 0 & N/A & 3.896 & 1.549 & 40 \\
\hline Total & 12.921 & 5.745 & 44 & 5.493 & 1.888 & 34 & 9.322 & 4.573 & 49 \\
\hline
\end{tabular}

mates for each brush species are also shown in Table 2. Since the counties used to obtain these estimates represented more than $50 \%$ of the total number and area of counties in most Extension Districts, the values provided in Table 1 could be used to obtain a rough estimate of the total area and total potential Brush Busters area within each district. If this were done, the total area across all 9 Extension Districts where Brush Busters could be applied would clearly exceed the estimates obtained from the useable responses. However, such extrapolations need to be treated with caution,

Table 1 indicates that, overall, approximately $44 \%$ of mesquite, $34 \%$ of juniper and $49 \%$ of pricklypear could be treated using Brush Busters. In each case, 3 Extension Districts represent about two thirds of the estimated Brush Busters treatable area. For mesquite, the South, Far West and West Central Extension Districts represent $66 \%$; for juniper, West Central, Southwest and Plains represent $69 \%$; and for pricklypear, the South, West Central and Plains represent $70 \%$ of the estimated treatable area.

Information was also requested about the area treated annually using Brush Busters from 1995 through 1998, and how the 1998 estimates of Brush Busters coverage compared with the area of other types of brush control treatments (Tables 3 and 4 , respectively). Because the estimates presented in Tables 3 and 4 are based on useable responses only, the total area of the 91 counties providing useable responses was also included. The reason for the differences in the total number of counties and area between Table 2 and Tables 3 and 4 , is that not all counties that provided useable estimates of total area of brush and Brush Busters treatable area also provided useable estimates of the total area treated in 1998.
It is apparent from Table 3 that the usable survey responses indicated that over 422,455 ha of brush have been treated using Brush Busters between 1995 and 1998, representing approximately $1.6 \%$ of the total area of the counties used to obtain these estimates. Of the treated area about $78 \%$ was associated with the treatment of mesquite, $10 \%$ was juniper, and $12 \%$ was pricklypear. Of the 329,024 ha of mesquite treated, $27 \%$ occurred in the South West district, $21 \%$ in the West Central district, $14 \%$ in both the Central and Coastal Bend districts. According to the information analyzed, the largest portion of the 43,375 ha of juniper treated occurred in the Panhandle District $(33 \%)$, followed by the West Central (24\%), Plains (19\%), and the Southwest (15\%). In the case of pricklypear, the greatest proportion of the 50,056 ha treated occurred in the West Central district (44\%), followed by the Southwest (28\%), Rolling Plains (9\%) and Central (9\%) districts. While the Extension Agents reported no clear trend in the application of Brush Busters from 1995 through 1997 (except for juniper), there was a substantial increase in its application between 1997 and 1998: mesquite (69\%), juniper (87\%), and pricklypear (143\%).

Despite these increases, the potential for the use of Brush Busters has clearly not been realized. Table 3 indicates that the area treated between 1995 and 1998, represents a small fraction of the estimated Brush Busters treatable area; mesquite representing about $11 \%$ and juniper and pricklypear both about $3 \%$ of the additional potentially treatable area. It should be noted that the estimates of total treatable area for each species based on the photographic thresholds (Table 1), are higher than the sum of the treated and additional potentially treatable area presented in Table 3. The reason for this is that more counties provided useable estimates for the question relating to the photographic thresholds than to the questions about areas treated in 1995 through 1998. Table 1 suggests that, with the exception of juniper, the estimated potential Brush Busters treatable area for each species might be substantially greater than the estimates presented in Table 3.

From Table 4 it is apparent that Brush

Table 2. Total area of the Extension Districts included in the survey and the area and number of responding counties used to estimate the area of Brush Busters treatable area in each District.

\begin{tabular}{lccccc}
\hline \hline & & \multicolumn{4}{c}{ Responding counties } \\
\cline { 2 - 6 } District name & $\begin{array}{c}\text { Area of District } \\
\left(\text { ha } \times 10^{6}\right)\end{array}$ & $\left(\right.$ ha x $\left.10^{6}\right)$ & Area* $^{*}$ & Number & $(\%)$ \\
\hline Panhandle & 5.275 & 2.194 & 42 & 8 & 38 \\
South Plains & 4.825 & 2.733 & 57 & 11 & 55 \\
Plains & 5.782 & 3.004 & 52 & 13 & 52 \\
Far West & 12.718 & 6.410 & 50 & 10 & 43 \\
West Central & 5.965 & 5.430 & 91 & 21 & 91 \\
Central & 4.948 & 3.144 & 64 & 14 & 67 \\
Southwest & 5.620 & 3.698 & 66 & 15 & 71 \\
Coastal Bend & 4.372 & 1.630 & 37 & 10 & 39 \\
South & 6.516 & 4.265 & 65 & 109 & 50 \\
Total & 56.021 & 32.508 & 58 & 57
\end{tabular}

*Area of responding counties as a percentage of the total area of the Extension District.

$* * \mathrm{~N}$ is the number of counties used to derive the values for each Extension District; $\mathrm{N}$ as a percentage of the total number of counties in each district is shown in parentheses. 
Table 3. Estimated area (ha) treated using Brush Busters from 1995 through 1998, and the estimated additional potentially treatable area.

\begin{tabular}{lrrrrrrr}
\hline \hline Brush Type & $\begin{array}{r}1995 \\
\text { (ha) }\end{array}$ & $\begin{array}{c}1996 \\
\text { (ha) }\end{array}$ & $\begin{array}{c}1997 \\
\text { (ha) }\end{array}$ & $\begin{array}{c}1998 \\
\text { (ha) }\end{array}$ & $\begin{array}{c}\text { Total treated } \\
\text { (ha) }\end{array}$ & $\begin{array}{c}\text { Additional } \\
\text { (ha) }\end{array}$ & $\begin{array}{c}\text { County area* } \\
\text { (ha, \%) }\end{array}$ \\
\hline Mesquite & 65,903 & 55,596 & 77,175 & 130,350 & 329,024 & $3,031,254$ & \\
Juniper & 3,248 & 7,187 & 11,463 & 21,477 & 43,375 & $1,558,417$ & $(47 \%)$ \\
Pricklypear & 9,684 & 7,969 & 9,430 & 22,973 & 50,056 & $1,614,266$ \\
Total & 78,835 & 70,752 & 98,068 & 174,800 & 422,455 & $6,203,937$ & $26,519,917$ \\
\hline
\end{tabular}

*Area (ha) of the 91 counties used for this analysis, and the percentage contribution of this area to the total area of all the counties included in the study.

Table 4. Estimated area (ha) treated and percentage of total area of mesquite, juniper, and pricklypear using various brush management treatments in 1998.

\begin{tabular}{|c|c|c|c|c|c|c|c|c|c|c|c|}
\hline \multirow[t]{2}{*}{ Brush Type } & \multicolumn{2}{|c|}{ Brush Busters } & \multicolumn{2}{|c|}{ Aerial Spray p } & \multicolumn{2}{|c|}{ Mechanical } & \multicolumn{2}{|c|}{ Prescribed Fire } & \multicolumn{2}{|c|}{ Total } & \multirow{2}{*}{$\begin{array}{c}\text { County area } \\
\text { (ha, \%) }\end{array}$} \\
\hline & (ha) & $(\%)$ & (ha) & $(\%)$ & (ha) & $(\%)$ & (ha) & $(\%)$ & (ha) & $(\%)$ & \\
\hline Mesquite & 130,350 & 34 & 56,654 & 15 & 138,999 & 36 & 55,424 & 15 & 381,427 & 57 & \\
\hline Juniper & 21,477 & 13 & 0 & 0 & 84,113 & 52 & 56,152 & 35 & 161,742 & 24 & $(47 \%)$ \\
\hline Pricklypear & 22,973 & 19 & 19,741 & 16 & 29,725 & 25 & 48,685 & 40 & 121,125 & 18 & \\
\hline Total & 174,800 & 26 & 76,395 & 12 & 252,838 & 38 & 160,261 & 24 & 664,294 & 100 & $26,519,917$ \\
\hline
\end{tabular}

*Area (ha) of the 91 counties used for this analysis, and the percentage contribution of this area to the total area of all the counties included in the study.

Busters treated area represented a significant proportion of the total area of brush treatments in 1998, especially in the case of mesquite $(34 \%)$, and to a lesser extent for juniper $(13 \%)$ and pricklypear $(19 \%)$. This is significant because mesquite treatments represented $57 \%$ of the total estimated area treated in 1998 in the 91 counties used for this analysis. While mechanical treatment was applied over a greater area than Brush Busters for mesquite, the increasing trend in the application of Brush Busters treatments for mesquite (Table 3 ), suggests that the proportional use of the 4 treatments included in Table 4 may change significantly in the future, especially for mesquite. Mechanical treatment was clearly the dominant method $(52 \%)$ used for controlling juniper, and fire was the most commonly used method (40\%) for controlling pricklypear. Thus, while there has been an increase in the application of Brush Busters for controlling juniper and pricklypear, the data in Tables 1,3 , and 4 indicate that mesquite presents the greatest potential for increasing the use of Brush Busters treatments.

To ascertain the perceived efficacy of Brush Busters, the Extension Agents were asked to rank their perceptions about the effectiveness of this brush control technique for achieving 3 range management objectives (Fig 4). Most ranked Brush Busters as being above average in its effectiveness for improving forage supply, wildlife habitat and rangeland health, but consistently considered it to be less effective for improving wildlife habitat, than for improving forage supply and rangeland health. This is somewhat surprising given the central role of individual plant treatment (IPT) in the brush sculpting approach to wildlife habitat improvement (Ueckert 1997). However, this finding appears to be consistent with variations in perceived landowner interests in Brush Busters. Figure 5 represents Extension Agents' rankings of their perceptions about the interest of various types of rangeland managers in Brush Busters relative to other rangeland improvement practices. Although the mean responses from the Extension Districts varied (West Central reported the highest landowner interest and the Plains and Far West the lowest), overall, livestock producers appear to have expressed a somewhat greater interest than wildlife ranchers in Brush Busters.

To determine why Brush Busters has become popular, Extension Agents were asked to list specific reasons for landowner and their own interests in this approach to brush management. Table 5 shows the number of times a particular characteristic of Brush Busters was identified as favor-

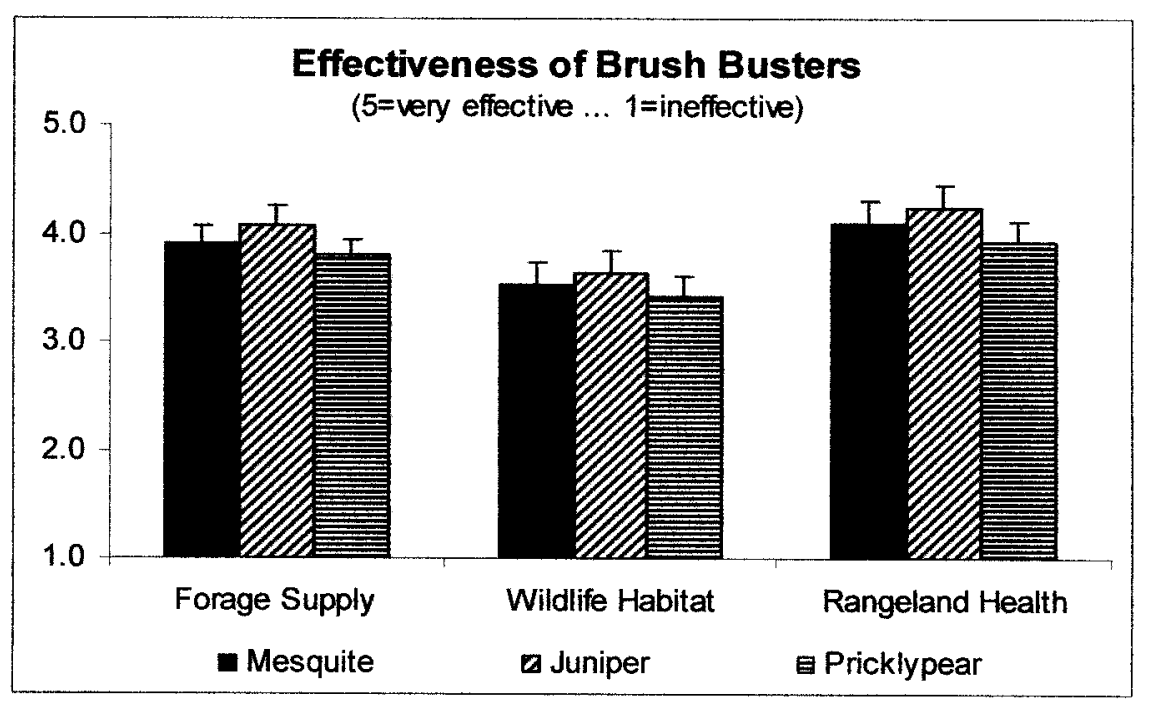

Fig. 4. Perceived effectiveness of Brush Busters for achieving three common rangeland management objectives. (Data dispersion bars represent $95 \%$ confidence limits.) 


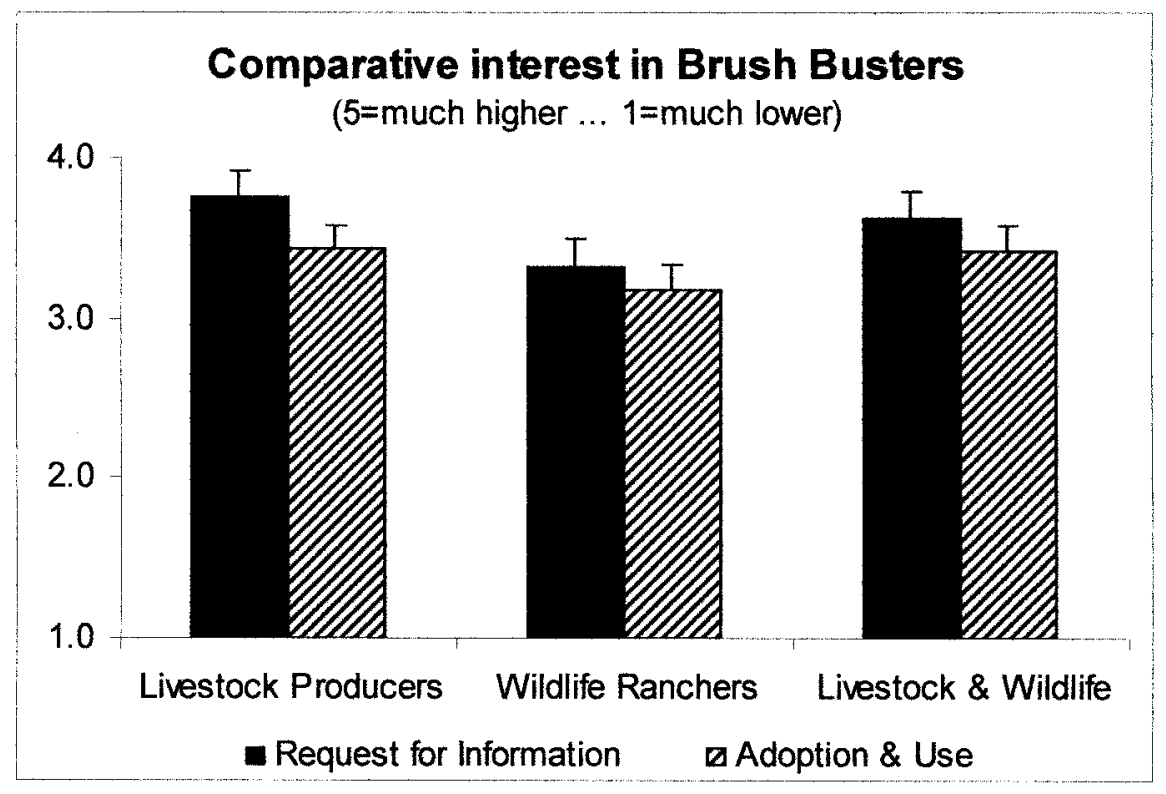

Fig. 5. Perceived interest of landowners in Brush Busters compared to other rangeland improvement practices. (Data dispersion bars represent 95\% confidence limits.)

able. The Extension Agents indicated that the relatively low cost, convenience, selectivity and effectiveness of Brush Busters for controlling unwanted plants are the most important reasons why landowners are interested in this approach to brush control. While these factors are also important to Extension Agents, other factors such as readily available informa- user-friendly information about the program is clearly a key factor for the rapid increase in interest in this approach to brush control.

To further determine why landowners have so readily adopted the Brush Busters approach to brush control, Extension Agents were asked to indicate the extent to which IPT had been promoted in the past (Fig. 6). At the time of the survey, the majority of responding counties were promoting IPT for brush control, either through dissemination of information $(88 \%)$, field days $(59 \%)$, or demonstration sites $(69 \%)$. However, these levels of promotion were not uniform across all Extension Districts. On average, the proportion of counties promoting IPT ranked as follows: West Central (93\%), Southwest (88\%), Plains (79\%), Central (75\%), Panhandle (74\%), Far West (72\%), Coastal bend $(64 \%)$, South $(59 \%)$, and South Plains (46\%). Also important is that the majority of Extension Agents (83\%) indicated that IPT for brush control had been promoted in their counties before the advent of Brush Busters. Therefore, factors other than the active promotion of IPT appear to be responsible for the high adoption rate of this type of brush control approach after 1995. As previously indicated (Table 5), the Extension Agents considered the ease of access to user-friendly information about Brush Busters to be a major benefit of the program.

Table 5. Number of times Extension Agents listed specific reasons for landowner and Extension Agents interest in Brush Busters.

\begin{tabular}{|c|c|c|c|c|c|c|c|c|c|c|}
\hline Perceived reasons for landowner interest & Panhandle & $\begin{array}{l}\text { South } \\
\text { Plains }\end{array}$ & Plains & $\begin{array}{c}\text { Far } \\
\text { West }\end{array}$ & Central & $\begin{array}{c}\text { West } \\
\text { Central }\end{array}$ & $\begin{array}{l}\text { South- } \\
\text { west }\end{array}$ & $\begin{array}{l}\text { Coastal } \\
\text { Bend }\end{array}$ & South & Total \\
\hline Relatively low cost & 3 & 4 & 8 & 2 & 2 & 0 & 2 & 8 & 4 & 33 \\
\hline Convenient, easy to apply, clear guidelines & 3 & 0 & 4 & 3 & 1 & 0 & 1 & 10 & 7 & 29 \\
\hline Selective, little herbicide drift, environmentally safe & 4 & 2 & 5 & 1 & 1 & 1 & 3 & 6 & 5 & 28 \\
\hline Effective, predictable, high \% kill & 2 & 1 & 5 & 0 & 1 & 0 & 2 & 9 & 4 & 24 \\
\hline Can treat small areas, increases flexibility and affordability & 0 & 0 & 5 & 0 & 0 & 0 & 2 & 5 & 0 & 12 \\
\hline Improves rangeland, forage production, and carrying capacity & 3 & 0 & 1 & 0 & 1 & 0 & 1 & 2 & 2 & 10 \\
\hline Little hired labor required & 0 & 0 & 2 & 0 & 0 & 0 & 0 & 6 & 1 & 9 \\
\hline Less use of herbicide than aerial spraying & 2 & 0 & 1 & 0 & 0 & 0 & 0 & 2 & 1 & 6 \\
\hline Large time window for application due to flexibility & 1 & 0 & 1 & 0 & 0 & 0 & 0 & 3 & 0 & 5 \\
\hline Suitable for containing brush invasion and density & 0 & 0 & 0 & 0 & 0 & 0 & 1 & 0 & 4 & 5 \\
\hline Little or no additional equipment needed & 1 & 0 & 1 & 0 & 0 & 0 & 0 & 2 & 0 & 4 \\
\hline Other & 0 & 1 & 7 & 0 & 2 & 0 & 2 & 5 & 5 & 22 \\
\hline Reasons for Extension Agents interest & Panhandle & $\begin{array}{l}\text { South } \\
\text { Plains }\end{array}$ & Plains & $\begin{array}{c}\text { Far } \\
\text { West }\end{array}$ & Central & $\begin{array}{l}\text { West } \\
\text { Central }\end{array}$ & $\begin{array}{c}\text { South- } \\
\text { west }\end{array}$ & $\begin{array}{c}\text { Coastal } \\
\text { Bend }\end{array}$ & South & Total \\
\hline Effective, high \% kill, predictable quick results, practical & 5 & 3 & 5 & 2 & 4 & 7 & 6 & 1 & 4 & 37 \\
\hline Easily available information, training, and demonstrated results & 1 & 1 & 2 & 2 & 3 & 5 & 3 & 1 & 6 & 24 \\
\hline Relatively low cost & 2 & 4 & 2 & 1 & 2 & 6 & 2 & 2 & 1 & 22 \\
\hline Convenient, easy to apply, clear guidelines & 3 & 0 & 1 & 1 & 2 & 4 & 4 & 1 & 3 & 19 \\
\hline Selective, control herbicide placement, environmentally safe & 0 & 2 & 0 & 0 & 3 & 4 & 3 & 2 & 1 & 15 \\
\hline Can treat small areas & 1 & 0 & 3 & 1 & 2 & 2 & 3 & 2 & 0 & 14 \\
\hline Improves rangeland, forage production, and carrying capacity & 0 & 3 & 0 & 0 & 0 & 2 & 0 & 0 & 1 & 6 \\
\hline Meets landowners needs & 0 & 0 & 0 & 1 & 1 & 3 & 1 & 0 & 0 & 6 \\
\hline Little hired labor required & 1 & 0 & 1 & 0 & 0 & 0 & 0 & 0 & 3 & 5 \\
\hline Can be used around building, corrals, fences, watering places & 0 & 0 & 0 & 2 & 0 & 1 & 0 & 0 & 1 & 4 \\
\hline Other & 0 & 4 & 5 & 3 & 3 & 3 & 3 & 2 & 3 & 26 \\
\hline
\end{tabular}




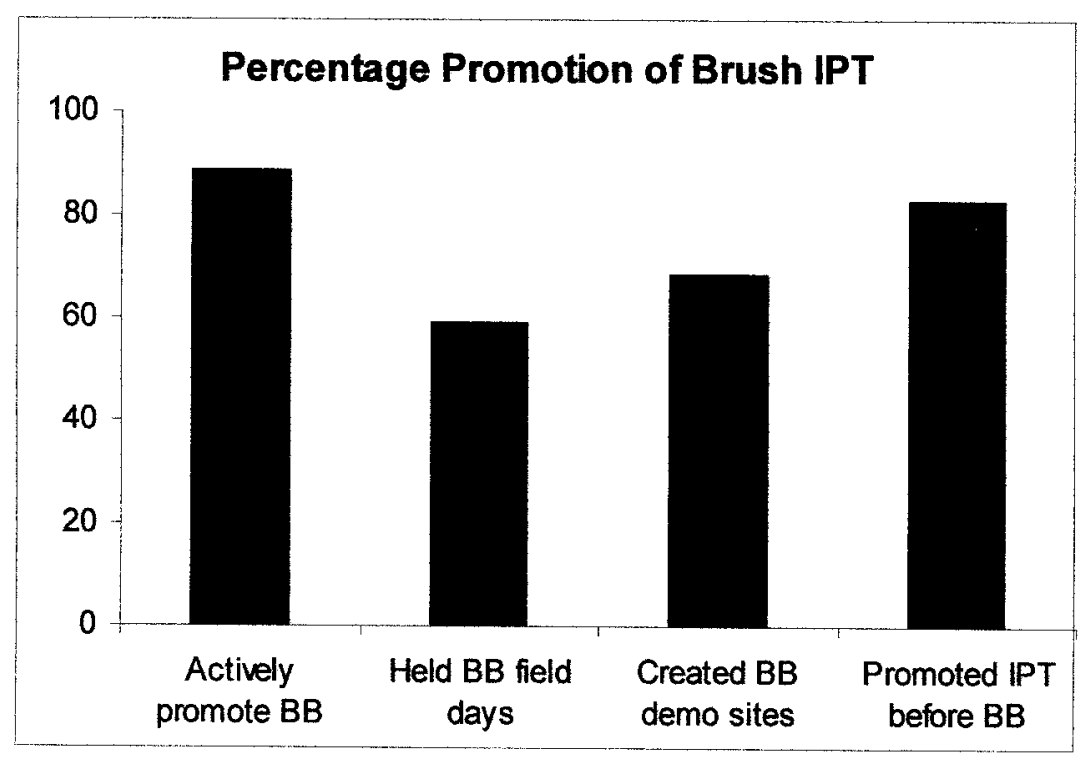

Fig. 6. Percentage of responding counties that have promoted individual plant treatments for brush control.

One of the novel aspects of the Brush Busters program was the development and dissemination of a wide array of information sources about this IPT approach to brush management, including notebooks, brochures, videos, and CDs, all of which bear the easily recognizable Brush Busters logo and name. Because of these numerous sources of information, Extension Agents were asked to identify which sources had been provided to their office (Fig. 7). The simply worded trifold brochures for the mesquite, juniper and pricklypear programs (McGinty and Ueckert 1995, 1996, Ueckert and McGinty 1997) were reported to be most widely received, as was the 3-ring binder about the program. Field days evidently have also provided an important source of information for nearly $70 \%$ of the responding Extension Agents, and the mesquite video and magazine articles were also reported to have been received as sources of information by over $50 \%$ of the respondents.

Finally, the Extension Agents were asked to identify brush species not currently covered under Brush Busters that could be managed with herbicide applications to individual plants. The main species listed and the number of times that they were listed were: huishache (Acacia smallii (L.) Willd.) - 15, mainly in the Coastal Bend district; Yucca sp. - 8, mainly in the Panhandle and South Plains districts; persimmon (Diospyros texana Scheele) - 5, mainly in the West Central and South districts; and saltcedar Liebm.), greenbriar (Smilax sp.), sand sage (Artemesia filifolia Torr.), catclaw (Accaci greggii Grey), African rue (Peganum harmala L.), willow baccharis (Baccharis salicina (R.\&P.) Pers.), lotebush (Zizyphus obtusifolia (T.\&G.) Gray), blackbrush (Acacia rigidula Benth.), and Chinese tallow (Sapium sebiferum (L.) Roxb.).

\section{Discussion and Conclusion}

The adoption of new or existing technology by land managers is affected by many factors other than its efficacy, including the land managers' age, education, income, goals, and level of community participation, the size and tenure status of the land, as well as the Extension, print media, and radio contact to which they have been exposed. While the influence of some of these factors may be relatively easily determined, psychological factors are often less tangible but more consequential than physical or economic factors in determining which technologies are implemented by land managers.

In our study we attempted to identify some of these factors by surveying County Extension Agents to determine how their own and landowners' interest in alternative brush management practices are influenced. The reason why we targeted Extension Agents and not landowners in

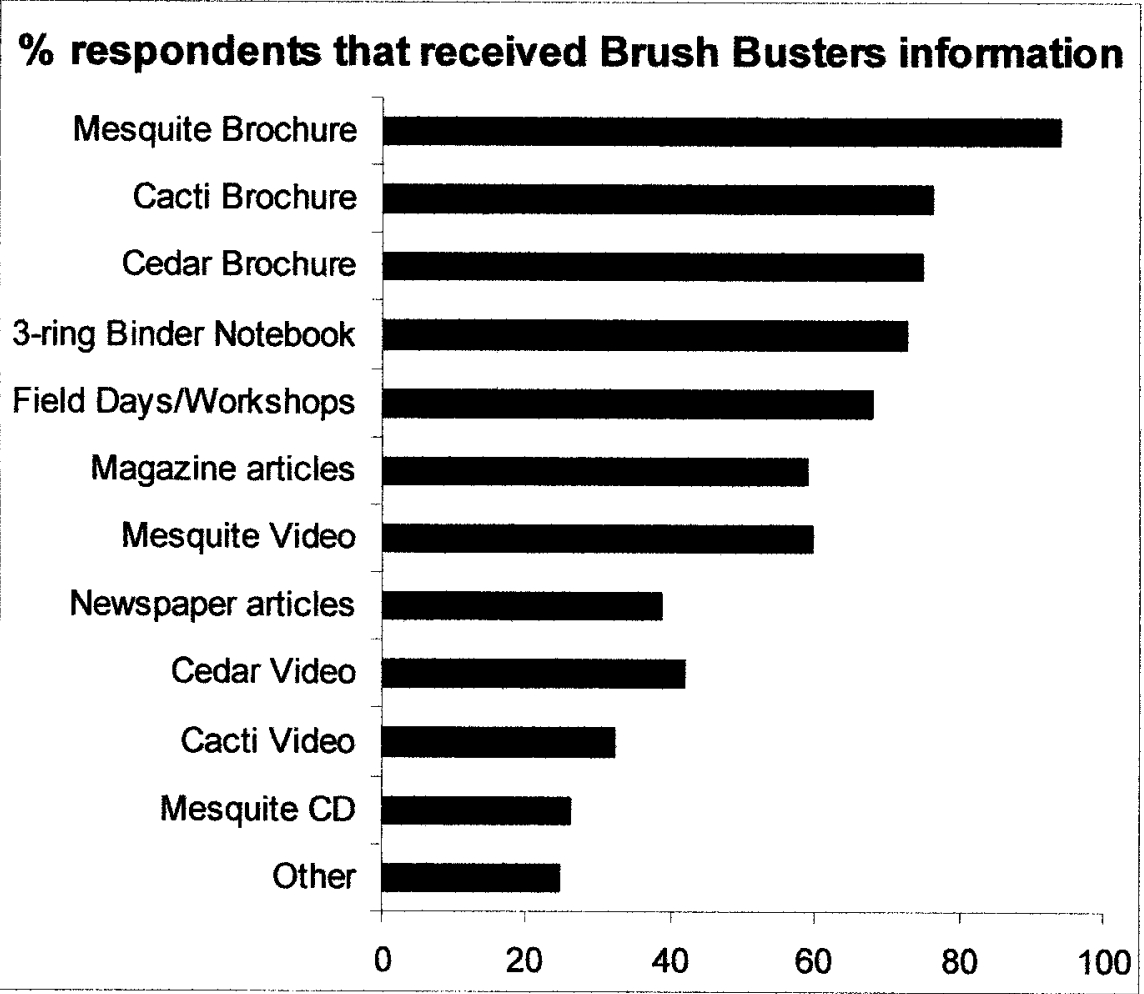

Fig. 7. Sources of information about Brush Busters received by the Extension Agents. 
this survey is that, because of the large areas that they service, it was logistically simpler to extract statewide information from the Extension Agents than from individual landowners. While the results of the survey might have been different had landowners been interviewed, we feel that because Extension Agents interact with numerous landowners, the information obtained from them provides a good first approximation of the factors that influence landowners' perceptions of alternative brush management practices.

Due to the increasing brush density on many rangelands and the associated negative impact on rangeland productivity for livestock, wildlife, and water production, it is critical to promote biologically effective, environmentally friendly, and economically efficient brush control technologies that have a high probability of being implemented by managers with a wide array of objectives. However, rangeland ecosystems are frequently complex and their responses to rangeland management practices are often delayed. This creates a challenge for rangeland management professionals attempting to promote sustainable management practices because most people are impatient to see evident rewards for their investments. Aversion to adopting new technologies tends to increase when responses are not only slow but also depend on environmental vagaries.

According to our study, Brush Busters has become popular because it is perceived to be an inexpensive, convenient, safe, effective and predictable method for controlling brush. Perhaps even more important to its success is the ready availability of user-friendly information about the program. Brush Busters was not developed strictly as a research program, but rather as a collaborative extension/research program between the TAEX and TAES in response to a rapidly increasing interest during the early 1990s in herbicide-based individual plant treatments (IPT) for controlling brush. While technical knowledge about tactical brush management was well established prior to this period, a vehicle for easily and widely disseminating this knowledge was lacking before the inception of Brush Busters. Thus, the major impetus for the development of Brush Busters was to disseminate pertinent information about IPT in order to reduce the need for repeated verbal communication. The partnership between TAEX, TAES, Dow AgroSciences LLC, and others resulted in widespread distribution of userfriendly information about Brush Busters across most of Texas, and several other States. Of particular importance were the simple tri-fold brochures (McGinty and Ueckert 1995, 1996, Ueckert and McGinty 1997), which greatly facilitated the dissemination of the information by Texas County Extension Agents. In addition, the notebook, videos, and compact disk produced about Brush Busters and the numerous field demonstrations enabled Extension Agents to easily inform themselves and others about the program.

The simplicity, predictability and cost effectiveness of the brush control methods promoted by Brush Busters, together with the collaborative agency/private sector technology "marketing" effort has resulted in rapid exposure throughout Texas, and successful technology transfer of IPT for brush control. Moreover, our survey showed that the area treated using Brush Busters methods between 1995 through 1998 represented only a small fraction of the total treatable area in Texas. In addition to the areas representing treatable heights and densities of plants, IPT could also be used to maintain reduced brush densities in areas where stands of brush that are initially too dense or too tall for IPT are first treated with alternative methods, such as broad scale herbicide or mechanical treatments. Thus, the potential for future implementation of the Brush Busters approach to brush control in Texas is substantial, not only for mesquite, juniper and pricklypear, but also for other problematic woody plants. In addition, while efforts to promote this approach to brush management have focused on Texas, there is substantial potential for implementing the program in many other States where the encroachment of brush and invasive species pose a problem for rangeland managers.

Our findings suggest that much greater emphasis needs to be placed on how information about rangeland management technologies is imparted to Extension Agents and land managers in order to increase the adoption rates of technologies that facilitate ecologically sound rangeland management. The agency/industry "marketing" partnership that propelled the spread of information about Brush Busters appears to be a key determinant for the rapid acceptance of new technology. In addition, rangeland management technologies that can be easily understood, are inexpensive, and which have relatively rapid and predictable results are more likely to be adopted by land managers than costly or complex strategies with delayed or uncertain responses. Thus in order for new tech- nologies to be rapidly adopted, rangeland researchers and Extension Agents should focus on providing simple messages about their technology and they should place greater emphasis on the visible short-term benefits rather than the long-term advantages of the technology.

\section{Literature Cited}

Archer, S. 1989. Have southern Texas savannas been converted to woodlands in recent history? Amer. Natur. 134:545-561.

Archer, S. 1994. Woody plant encroachment into southwestern grasslands and savannas: rates, patterns and proximate causes, $\mathrm{p}$. 13-68. In: M. Vavra, W. Laycock, and R. Pieper (eds.), Ecological implications of livestock herbivory in the West. Soc. Range Manage. Denver, Colo.

Archer, S. and Chris Stokes. 2000. Stress, distribution and change in rangeland ecosystems, p. 17-38. In: Olafur Arnalds and Steve Archer (eds.), Rangeland desertification. Kluwer Acad. Publ. Dordrecht, The Netherlands.

Barao, S.M. 1992. Behavioral aspects of technology adoption. J. Ext. 30:13-15.

Bovey, R.W. 1998. A fifty-year history of the weed and brush program in Texas and suggested future directions. Texas Agr. Exp. Sta. Bull. B-1729. College Station, Tex.

Dillman, D.A. 1978. Mail and telephone surveys: The total design method. John Wiley and Sons. New York, N.Y..

Douglass, J.E. 1983. The potential for water yield augmentation from forest management in the Eastern United States. Water Resource Bull. 19:351-358

Fliegel, F.C. 1993. Diffusion research in rural sociology. Greenwood Press, Westport, Conn.

Fulbright, T.E. 1997. Designing shrubland landscapes to optimize habitat for whitetailed deer, p. 61-66. In: Dale Rollins, Darrell N. Ueckert, and Cristy G. Brown (eds.), Proc. Brush Sculptors Symposium. Texas A\&M University Res. and Ext. Center, San Angelo, Tex.

Hanselka, C.W., W.T. Hamilton, and B.S. Rector. 1996. Integrated brush management systems in Texas. Texas Agr. Ext. Serv. Leaflet L-5164. College Station, Tex.

Hanselka, C.W., J.C. Paschal, and C.L. Ricahrdson. 1991. South Texas ranching: A profile. Texas Agr. Exp. Serv. Bull. B-5010. College Station, Tex.

Hanselka C.W., A. McGinty, B.S. Rector, R.C. Rowan and L.D. White. 1990. Grazing and brush management on Texas rangelands: An analysis of management decisions. Texas Agr. Ext. Service Tech. Rep., College Station, Tex. 
Jofre, R. and S. Randal. 1993. How tree cover influences the water balance of Mediterranean rangelands. Ecol. 74:570-582.

Kreuter, U.P., S.R Archer, and C.J. Scifres. 1999. Bio-economic basis for woody plant management, p. 842-843. In: David Eldridge and David Freudenberger (eds.), Proc. $6^{\text {th }}$ Int. Rangeland Congress, Townsville, Australia.

Kreuter, U.P., R.C. Rowan, J.R. Conner, J.W. Stuth and W.T. Hamilton, 1996. Grazinglands Alternative Analysis Tool (GAAT): An economic analysis tool for range improvement. J. Range Manage. 49:464-469.

McGinty, A. and D. Ueckert. 1995. Brush Busters - how to beat mesquite: A safe and effective three-step way to control mesquite on small or large areas. Texas Agr. Ext. Serv. and Texas Agr. Exp. Sta. Leaflet L-5144.

McGinty, A. and D. Ueckert. 1996. Brush Busters - how to master cedar: Three safe and effective ways to control small cedar (juniper). Texas Agr. Ext. Serv. and Texas Agr. Exp. Sta. Leaflet L-5160.

Rowan, R.C., and L.D. White. 1994. Regional differences among Texas rangeland operators. J. Range Manage. 47:338-342
Rowan, R.C., H.W. Laedig, and L.D. White. 1994. Perceptions vs. recommendations: A rangeland decision making dilemma. J. Range Manage. 47:344-348.

Schlessinger, W.H., J.F. Reynolds, G.L. Cunningham, L.F. Huenneke, W.M. Jarrell, R.A. Virginia, and W.G. Whitford. 1990. Biological feedbacks in global desertification. Science 247:1043-1048.

Scifres, C.J. 1980. Brush management: principles and practices for Texas and the Southwest. Texas A\&M Univ. Press, College Station, Tex.

Scifres, C.J., J.L. Mutz, G.A. Rasmussen, and R.P. Smith. 1983. Integrated brush management systems (IBMS): Concepts and potential technologies for running mesquite and whitebrush. Texas Agr. Exp. Sta. Bull. B-1450, College Station, Tex.

Teague, W.R., R.J. Ansley, U.P. Kreuter, J.M. McGrann and W.E. Pinchak. 2001. Economics of managing mesquite with prescribed fire and root-killing herbicides: a sensitivity analysis. J. Range Manage. 54:553-560.

Thurow, T.L., A.P. Thurow, and M.D. Garriga. 2000. Policy prospects for brush control to increase off-site water yield. J. Range Manage. 53:23-31.
Ueckert, D.N. 1997. Brush Busters: The precursor to Brush Sculptors, p. 8-12. In: Dale Rollins, Darrell N. Ueckert, and Cristy G. Brown (eds.), Proc. Brush Sculptors Symposium. Texas A\&M University Res. and Ext. Center, San Angelo, Tex.

Ueckert, D.N. and A. McGinty. 1997. Brush Busters - how to take care of pricklypear and other cacti. Texas Agr. Exp. Sta. and Texas Agr. Ext. Serv. Leaflet L-5171.

Ueckert, D.N., W.A. McGinty, and U.P. Kreuter. 1999. Brush Busters: Marketing Prosopis management technology, p. 580-581. In: David Eldridge and David Freudenberger (eds.), Proc. $6^{\text {th }}$ Int. Rangeland Congress, Townsville, Australia.

White, L.D. 1987. Technology transfer and total ranch management. p. 125-128. In: R.S. White and R.E. Short (eds.), Proc. Fort Keogh Res. Symposium: Achieving efficient use of rangeland resources. Montana. Agr. Exp. Sta., Bozeman, Mont.

Workman, J.P. 1986. Range economics. MacMillan, New York. N.Y.

Zepada, L. 1994. Simulataneity of technology adoption and productivity. J. Agr. Resource Econ. 19:46-57. 


\title{
Nutritional dynamics of 7 northern Great Basin grasses
}

\author{
DAVE GANSKOPP AND DAVE BOHNERT
}

Authors are rangeland scientist, USDA-ARS, Eastern Oregon Agricultural Research Center ${ }^{1}$, HC-71 4.51 Hwy. 205, Burns, Ore. 97720; and range animal nutritionist, Oregon State University, E.O.A.R.C., HC-71 .4.51 Hwy. 205, Burns, Ore. 97720.

\section{Abstract}

Land, livestock, and wildlife managers need to understand the nutritional dynamics of forages to sustain adequate growth and reproduction of their animals and/or assure equitable payment for forages. Despite a long history of livestock grazing in the northern Great Basin, seasonal and annual nutritional dynamics of many of the region's prominent grasses have not been described. We addressed this issue via monthly sampling of 7 cool-season grasses at 6 sites during 1992, a drier than average year having $86 \%$ of mean precipitation, and 1993, when above average precipitation (167\% of average) occurred. With high yields predicted in $1993\left(1,257 \mathrm{~kg} \mathrm{ha}^{-1}\right)$, the period of adequate forage quality [crude protein $(\mathrm{CP}) \geq 7.5 \%$ ] was 83 days. In addition grasses did not respond to $97 \mathrm{~mm}$ of July-August rain with renewed growth. During 1992, a growing season beginning with less than average moisture, grasses responded to midsummer (49 $\mathrm{mm})$ and fall $(69 \mathrm{~mm})$ rains by maintaining greater than $7.5 \% \mathrm{CP}$ for 185 days. A diversity of grasses expanded the period of adequate forage quality especially during the lower than average moisture year. Giant wildrye (Elymus cinereus Scribn. \& Merr.), a deeply rooted grass, supported high quality forage until mid August, but did not respond to late-season moisture. In contrast, shallow rooted grasses like bottlebrush squirreltail (Sitanion hystrix (Nutt.) Smith), Sandberg's bluegrass (Poa sandbergii Vasey), and the winter-annual cheatgrass (Bromus tectorum $\mathbf{L}$.) responded to summer or fall moisture with herbage ranging from 10 to $16 \% \mathrm{CP}$, thereby supplying high quality late-season forage. With most precipitation occurring in the northern Great Basin during colder months, livestock or habitat managers can, with a fair degree of certainty, predict yields from their pastures before turnout. With abundant moisture, managers will see the rapid deterioration of forage quality that occurs when grasses advance through their reproductive stages of phenology and generate a wealth of reproductive stems. The quandary arrives, however, when moisture accumulations are less than optimum. Fewer reproductive tillers develop, and our results show that timely precipitation may elevate desirable nutrient characteristics and expand the duration of adequate livestock/wildlife nutrition in the region. More long-term research is needed to decipher the mechanisms governing growth and development of rangeland grasses and to assess risks of various stocking alternatives when managers face uncertain yield and forage quality issues.

${ }^{1}$ Eastern Oregon Agricultural Research Center, including the Burns and Union Stations, is jointly operated by the USDA-Agricultural Research Service and the Oregon Agr. Exp. Sta. of Oregon State University.

Technical Paper No. 11737 Oregon Agr. Exp. Sta.

Manuscript accepted 21 Dec. 00.
Resumen

Los manejadores de tierras, ganado y fauna silvestre necesitan entender las dinámicas nutricionales de los forrajes para mantener un crecimiento y una reproducción adecuados de sus animales y/o asegurar el pago equitativo de sus forrajes. A pesar del largo historial de apacentamiento de ganado en la Gran Cuenca del norte, las dinámicas nutricionales estacionales y anuales de muchos de los zacates prominentes de la región no se han sido descritas. Nosotros abordamos este problema a través de muestreos mensuales de 7 zacates de estación fría en 6 sitios durante 1992, un año mas seco que el promedio teniendo solo el 86\% de la precipitación media, y en 1993 cuando ocurrió una precipitación arriba del promedio $(167 \%$ de la precipitación media). Con rendimientos altos predichos en $1993\left(1,257 \mathrm{~kg} \mathrm{ha}^{-1}\right)$, el período en el que el forraje tuvo una calidad adecuada [proteína cruda $(P C) \geq 7.5 \%$ ] fue de 83 días. Además, los zacates no respondieron con crecimiento nuevo a los $97 \mathrm{~mm}$ de lluvia que ocurrieron entre Julio y Agosto. Durante 1992, una estación de crecimiento que inicio con menos humedad del promedio, los zacates respondieron a las lluvias de mediados de verano (49 $\mathrm{mm})$ y otoño $(69 \mathrm{~mm})$ al mantener el contenido de proteína cruda arriba del $7.5 \%$ durante 185 días. Una diversidad de zacates expandió el período de calidad adecuada del forraje, especialmente durante el año de precipitación abajo del promedio. "Giant wildrye" (Elymus cinereus Scribn. \& Merr.), un zacate con raíz profunda, mantuvo una calidad alta hasta mediados de Agosto, pero no respondió a la humedad de fines de estación. En contraste, zacates de raíz poco profunda como "Bottlebrush squirreltail (Sitanion hystrix (Nutt.) Smith), "Sandberg's bluegrass" (Poa sandhergii Vasey) y el anual invernal "Cheatgrass" (Bromus tectorum L.) respondieron a la humedad de verano y otoño con un contenido de proteína cruda en el forraje que varió 10 a $16 \%$, por lo tanto suministraron un forraje de alta calidad a fines de la estación de crecimiento. En la región de las Gran Cuenca del Norte, en donde la mayor precipitación ocurre durante los meses fríos, los manejadores de ganado o de hábitat pueden, con un grado regular de certidumbre, predecir los rendimientos de sus potreros antes de que este ocurra Con precipitación abundante, los manejadores verán el rápido deterioro de la calidad del forraje, la cual ocurre cuando los zacates avanzan a través de sus etapas fenológicas reproductivas y generan una abundancia de tallos reproductivos. Sin embargo, el dilema llega cuando las acumulaciones de humedad son menores al óptimo. Pocos tallos reproductivos se desarrollan y nuestros resultados muestran que la precipitación oportuna puede elevar las características nutritivas deseables y extender la duración de una nutrición adecuada para el ganado y fauna silvestre de la región. Se requiere una investigación de más larga duración para descifrar los mecanismos que gobiernan el crec 
imiento y desarrollo de los zacates de pastizal y evaluar los riesgos de varias alternativas de carga animal cuando los manejadores encaran problemas de incertidumbre respecto a los rendimientos y calidad del forraje.

Key Words: crude protein, neutral detergent fiber, in vitro organic matter disappearance, Poa sandbergii, Bromus tectorum, Sitanion hystrix, Agropyron spicatum, Festuca idahoensis, Stipa thurberiana, Elymus cinereus

Stockmen and wildlife managers need to understand nutritional dynamics of forages on rangelands to sustain adequate growth and reproduction of their animals. In a similar vein, those marketing pasture should also be aware of nutritional characteristics of their forages to assure reception of equitable payment. Despite a long history of livestock grazing in the northern Great Basin, there have been few concerted efforts to quantify seasonal and annual nutritional dynamics of many of the region's most prominent rangeland grasses (Murray et al. 1978).

The northern Great Basin experiences an arid Mediterranean climate with about $80 \%$ of the annual precipitation occurring in the fall, winter, and spring months when low temperatures preclude plant development. Rangeland grasses typically initiate growth with warming temperatures in March or April, and herbage accumulations cease with depletion of soil moisture in mid- to late July (Sneva 1982, Ganskopp 1988). Wallace et al. (1961) described in vitro cellulose digestibility of 6 grasses from 30 May to 5 September, with values ranging from a high of $76 \%$ to a low of $37 \%$ late in the season. Raleigh (1970) and McInnis and Vavra (1987) monitored nutritional indices of grasses from late April to early September and noted that forage quality began deteriorating even before stems started elongating in the spring. Quality continues to decline until early August when forages mature and dry (Raleigh 1970, Murray et al. 1978). Murray et al. (1978) also quantified mineral content for several of the region's grasses. Rates of gain for livestock reflect nutritional dynamics of the region's forages with mature cows gaining up to 1.86 $\mathrm{kg}$ day $^{-1}$ early in the growing season and losing $0.4 \mathrm{~kg} \mathrm{day}^{-1}$ by mid- to late August (Raleigh and Wallace 1965, Turner and DelCurto 1991). Within the same period, calf gains may range from 0.7 to as little as $0.1 \mathrm{~kg} \mathrm{day}^{-1}$ (Turner and DelCurto 1991).
Our objective was to characterize seasonal and annual nutritional dynamics of 7 of the region's most prominent grasses. This was accomplished via monthly sampling at 6 sites during 1992, a drier than average year, and 1993 when above average precipitation occurred.

\section{Materials and Methods}

After extensive reconnaissance in the fall of 1991, six study locations within the vicinity of Burns, Ore. were selected with each supporting a broad array of forages (Table 1). Climatological data reported here were acquired at the Northern Great Basin Experimental Range with the recording unit identified as the Squaw Butte Experiment Station in N.O.A.A. records (N.O.A.A. 1991 through 1994). The second site listed in Table 1 provides coordinates for the weather station. Among the 6 locations, mean soil depth was $69 \mathrm{~cm}(\mathrm{se}=5.1)$, and elevation ranged from 1,375 to $1,472 \mathrm{~m}(\overline{\mathrm{x}}=1,429)$. On an east/west line the sites spanned $118 \mathrm{~km}$, while the north/south extreme encompassed $75 \mathrm{~km}$.

The shrub component at each site was dominated by Wyoming big sagebrush (Artemisia tridentata subsp. wyomingensis Beetle) with occasional occurrences ( $<10 \%$ relative cover) of mountain big sagebrush (Artemisia tridentata subsp. vaseyana (Rydb.) Beetle). Dominant perennial grasses were either bluebunch wheatgrass (Agropyron spicatum (Pursh)Scribn. \& Smith) or Idaho fescue (Festuca idahoensis Elmer). Subordinate grasses included Sandberg's bluegrass (Poa sandbergii Vasey), bottlebrush squirreltail (Sitanion hystrix (Nutt.) Smith), Thurber's needlegrass (Stipa thurberiana Piper), giant wildrye (Elymus cinereus Scribn. \& Merr.), prairie Junegrass (Koeleria cristata Pers.), and in disturbed areas, the introduced annual cheatgrass

Table 1. Coordinates, elevation, and soils classification of sites where 7 species of grasses were harvested for assays of forage quality in southeastern Oregon during 1992 and 1993.

\begin{tabular}{|c|c|c|}
\hline Coordinates & Elevation $(\mathrm{m})$ & Soil \\
\hline $120^{\circ} 03^{\prime} 29^{\prime \prime} \mathrm{W} \quad 43^{\circ} 34^{\prime} 54^{\prime \prime} \mathrm{N}$ & 1463 & fine-loamy, mixed, frigid Aridic Argixerolls \\
\hline $119^{\circ} 42^{\prime} 30^{\prime \prime} \mathrm{W} 43^{\circ} 29^{\prime} 37^{\prime \prime} \mathrm{N}$ & 1452 & fine-loamy, mixed, frigid Aridic Argixerolls \\
\hline $119^{\circ} 19^{\prime} 08^{\prime \prime} \mathrm{W} \quad 43^{\circ} 28^{\prime} 59^{\prime \prime} \mathrm{N}$ & 1472 & loamy-skeletal, mixed frigid Lithic Argixerolls \\
\hline $119^{\circ} 00^{\prime} 21^{\prime \prime} \mathrm{W} \quad 43^{\circ} 26^{\prime} 45^{\prime \prime} \mathrm{N}$ & 1375 & loamy-skeletal, mixed, frigid Aridic Haploxerolls \\
\hline $118^{\circ} 39^{\prime} 01^{\prime \prime} \mathrm{W} \quad 43^{\circ} 59^{\prime} 05^{\prime \prime} \mathrm{N}$ & 1402 & $\begin{array}{l}\text { clayey-skeletal, montmorillonitic, frigid Lithic Xeric } \\
\text { Haplargids }\end{array}$ \\
\hline $118^{\circ} 35^{\prime} 55^{\prime \prime} \mathrm{W} 43^{\circ} 39^{\prime} 40^{\prime \prime} \mathrm{N}$ & 1411 & loamy-skeletal, mixed, frigid Aridic Haploxerolls \\
\hline
\end{tabular}

(Bromus tectorum L.). All of these grasses are common in the sagebrush steppe, and with the exception of prairie Junegrass, one or another may dominate the herbaceous layer depending on site specific conditions and environmental factors (Daubenmire 1970, Hironaka et al. 1983). study. These included: Sandberg's bluegrass, cheatgrass, bottlebrush squirreltail, bluebunch wheatgrass, Idaho fescue, Thurber's needlegrass, and giant wildrye. In 1992 and 1993, we visited all 6 locations within a 3-day interval at the end of each month. Months sampled included April-November in both years.

Once a month at each site samples were harvested from at least 6 plants per species by clipping to a $2.5-\mathrm{cm}$ stubble and compositing materials by species. Greater numbers of plants were used for small stature grasses like Sandberg's bluegrass. Plants at each site were sampled as encountered along a pace transect until adequate amounts of material were obtained. Each site experienced light $(<40 \%$ utilization) summer-fall grazing by cattle, but only ungrazed plants were included in our collections. Samples gathered prior to the beginning of spring growth consisted of leaves and culms generated in the previous growing season. After growth initiated in the spring, crowns of caespitose grasses were lightly crushed and the brittle and broken old-growth brushed aside before samples were collected. Samples were stored in paper bags in the field and transported to Eastern Oregon Agricultural Research Center headquarters where they were oven-dried at $60^{\circ} \mathrm{C}$ for 48 hours, ground to pass a 1-mm screen, and stored in plastic bags at room temperature for subsequent chemical analyses. Samples were analyzed for crude protein content $(\mathrm{CP}=$ Kjeldahl nitrogen $\times 6.25$; AOAC 1984), neutral detergent fiber (NDF; Robertson and Van Soest 1981), and percent in vitro organic matter disappearance (IVOMD; AOAC 1990).
Seven grasses were evaluated in this 
Experimental design was a randomized complete block with 6 replications (sites) and 3 factors (years $(\mathrm{n}=2)$, months $(\mathrm{n}=$ $8)$, and forages $(n=7)$ ). Initial analyses employed a split-split-plot analysis of variance with species as whole-plots, years as subplots, and months as sub-subplots (Petersen 1985). The replication $X$ species error term $(30 \mathrm{df})$ was used to test for species effects. The replication $\times$ year $\times$ species error term $(35 \mathrm{df})$ tested the main effect of year and year $\times$ species interaction, and the species $\times$ year $\times$ replication $\times$ month error term (490 df) tested for month main effects and the month $x$ forage, species $\times$ month, and species $\times$ year $X$ month interactions. Year effects and all interactions involving year effects were found to be highly significant $(\mathrm{P}<$ 0.001 ), so data were sorted by year, and years were analyzed separately using a split-plot analysis of variance with species serving as whole plots. Mean separations within a forage between adjacent months were obtained with Fisher's protected LSD (Fisher 1966) with statistical significance accepted at $\mathrm{P} \leq 0.05$. Associations among CP, IVOMD, and NDF variables pooled across replications, years, months, and forages were quantified via correlation analyses $(n=672)$.

\section{Results}

\section{Weather patterns}

Precipitation accumulations compiled on a calendar year basis at the Northern Great Basin Experimental Range were 106 and $140 \%$ of the long-term average $(\overline{\mathrm{x}}=$ $283 \mathrm{~mm}, \mathrm{n}=41$ ) for 1992 and 1993, respectively (N.O.A.A. 1992-1993). Sneva (1982), however, established that annual forage yields in the region were most closely correlated with precipitation accumulated on a crop year or September through June basis. With that logic, accumulations for the 1992 and 1993 growing seasons at the Northern Great Basin Experimental Range were 86 and $167 \%$ of the crop year average $(255 \mathrm{~mm})$, respectively (Fig. 1). Mean April-July temperatures were $2.5^{\circ} \mathrm{C}$ warmer than average $(\overline{\mathrm{x}}$ $=12.4^{\circ} \mathrm{C}$ ) in 1992 and $1.6^{\circ}$ cooler than average in 1993. A model for predicting annual herbage yields in the region furnished production estimates of $542 \mathrm{~kg} \mathrm{ha}^{-1}$ for 1992 and $1,257 \mathrm{~kg} \mathrm{ha}^{-1}$ for 1993 (Sneva 1982).

\section{Forage quality assessments}

All 3 indices of forage quality (CP, IVOMD, and NDF), were significantly

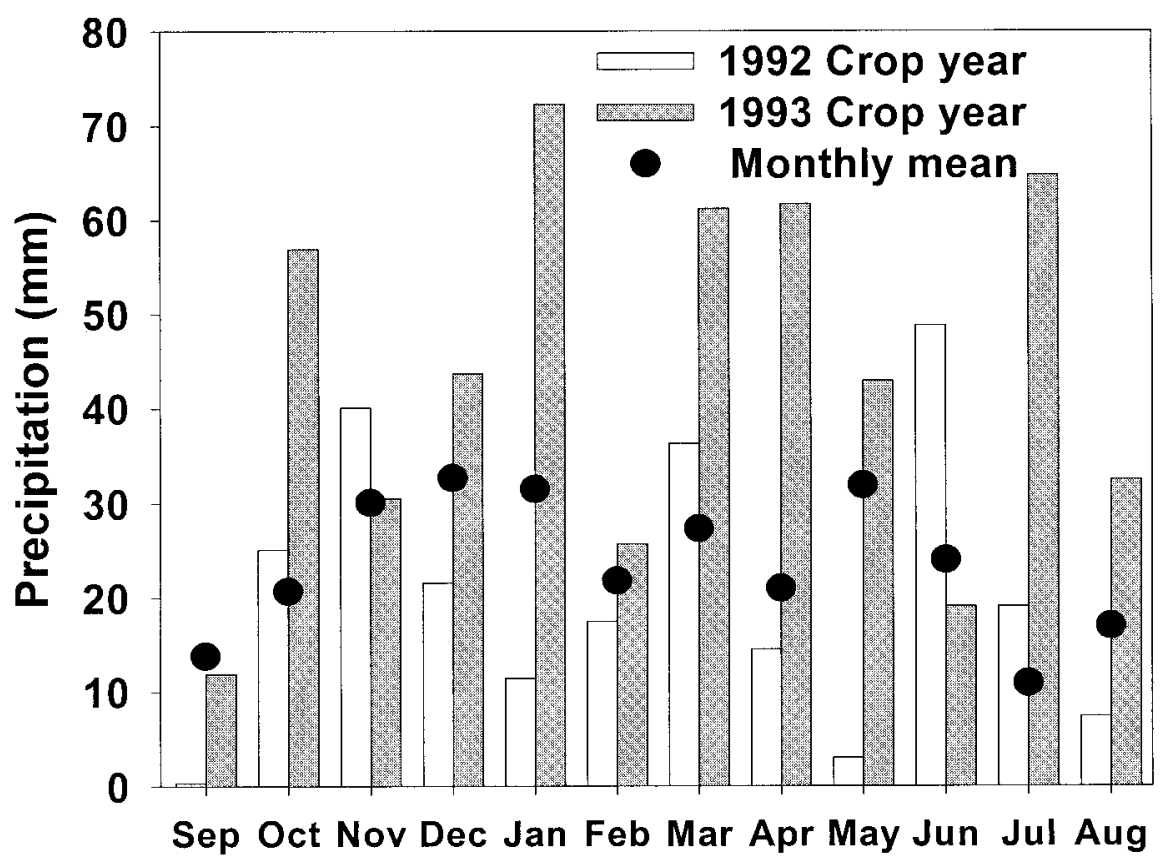

Fig. 1. Monthly precipitation for the 1992 (September 1991-June 1992) and 1993 (September 1992-June 1993) crop-years, plus the months of July and August in 1992 and 1993, and mean monthly accumulations $(n=41)$ at the Northern Great Basin Experimental Range near Burns, Ore.

affected by year and interactions involving years $(\mathrm{P}<0.001)$. Overall, year main effects averaged about $12 \%$ of the total variation in the split-split-plot analyses of variance. When years were removed from the models and analyzed separately, main effects of species and months, and the month $\times$ species interactions were again all highly significant $(\mathrm{P}<0.001)$. When averaged among all 3 indices of forage quality and both years, the main effect of month accounted for about $80 \%$ of the total variation, and species of forage contributed approximately $10 \%$. As a result, data for each species are presented at a monthly resolution for each year.

\section{Crude protein}

The highest CP content $(25 \%)$ was obtained with giant wildrye during the spring of 1993 (Fig. 2), and the lowest level $(2 \%)$ occurred with cheatgrass in late-September of 1993. In both years, all of the grasses exhibited their most rapid declines in CP concentrations from lateApril to late-June. With the exception of giant wildrye, CP content generally approached minimum levels by late July with no significant $(\mathrm{P}>0.05)$ declines thereafter. In giant wildrye, crude protein levels were sustained until late September. The greatest amount of variation in $\mathrm{CP}$ content was exhibited by Sandberg's bluegrass, and the least was displayed by blue- bunch wheatgrass. The seasonal range in CP content averaged from 10 to 17 percentage points in 1992 and 1993, respectively. Giant wildrye exhibited the greatest seasonal variation in both years and the lowest seasonal variation occurred in Idaho fescue in 1992 and Thurber's needlegrass in 1993.

Two patterns clearly illustrate the significant $(\mathrm{P}<0.001)$ year effects and interactions that occurred with our initial analyses of variance (Fig. 2). First, initial CP concentrations were consistently higher in 1993 than in 1992 but subsequently declined to lower levels in 1993 than in 1992. Second, the CP declines in 1993 appeared curvilinear and could probably be modeled by second order response functions, while CP levels in 1992 generally displayed 3 peaks that would be difficult to describe numerically. These 1992 fluctuations were induced by summer and fall precipitation events. In late-July 1992, bottlebrush squirreltail responded significantly $(\mathrm{P}<0.05)$ to $49 \mathrm{~mm}$ of rain in the preceding month with an increase of 4.9 percentage units in $\mathrm{CP}$ content. The other 6 grasses displayed similar patterns with slight elevations in $\mathrm{CP}$, but their increases were not significant $(\mathrm{P}>0.05)$.

Fifty-seven millimeters of rain in October 1992 induced growth and nutrient uptake and significantly elevated lateOctober CP in Sandberg's bluegrass, 

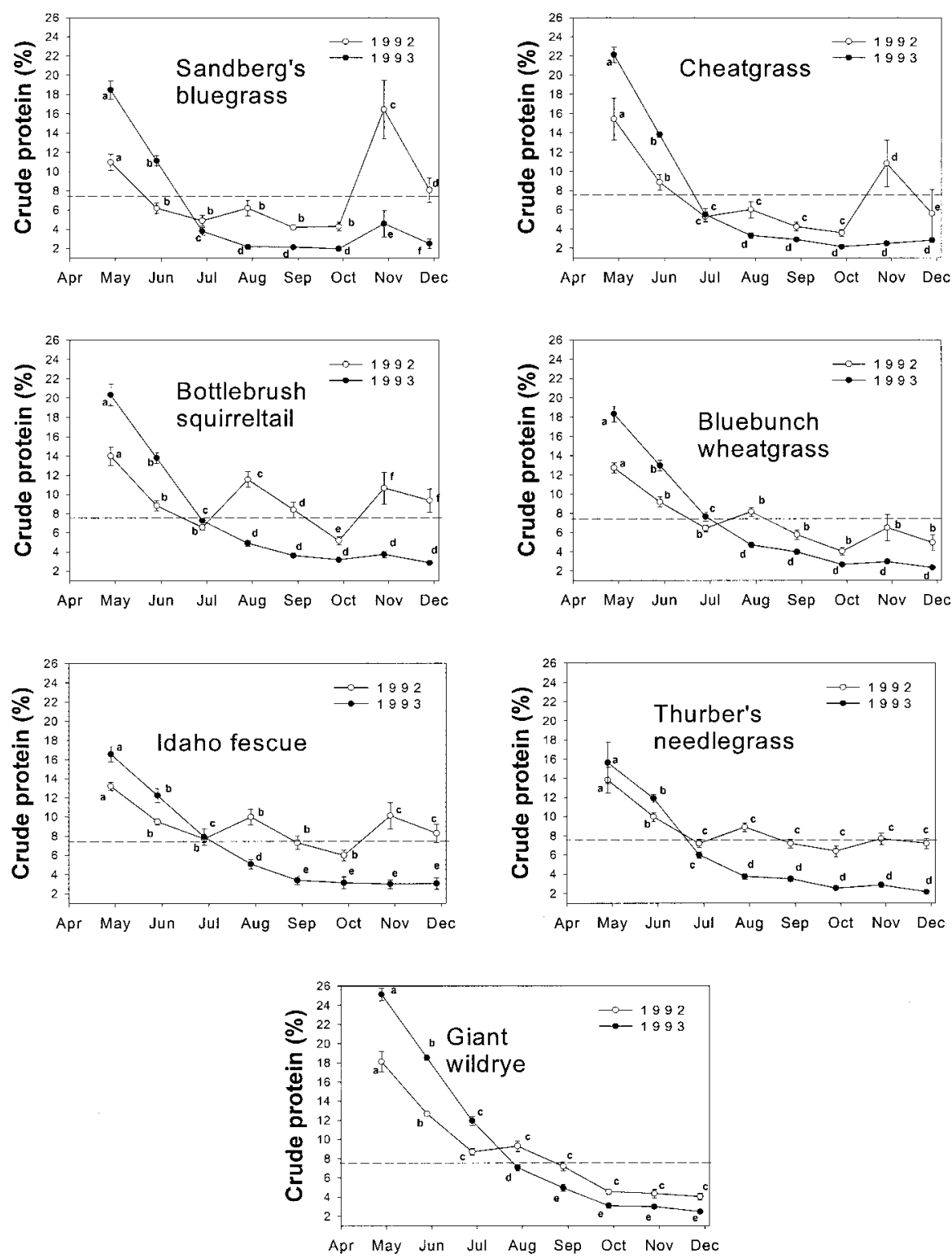

Fig. 2. Percent crude protein $( \pm \mathrm{SE})$ of 7 grasses sampled over 8 monthly intervals at 6 different sites in the sagebrush steppe near Burns, Ore. during 1992 and 1993. Dashed horizontal lines (- - - - ) depict a 7.5\% CP level. Adjacent monthly means within a year sharing a common letter are not significantly different $(P>0.05)$. LSD $(P=0.05)=2.8$ for 1992 and 1.5 for 1993.

cheatgrass, bottlebrush squirreltail, and Idaho fescue. Bluebunch wheatgrass, Thurber's needlegrass, and giant wildrye showed no significant responses. Oddly, the second highest monthly accumulation of rain $(65 \mathrm{~mm})$ that occurred during the study (July 1993) failed to elicit a significant $(\mathrm{P}>0.05)$ response from any of the grasses. Precipitation accumulations for September, October and November of 1993 were 1,14 , and $0 \mathrm{~mm}$, respectively, and no fall green-up occurred among any of the grasses.

\section{In vitro organic matter disappearance}

The highest IVOMD (81.8\%) occurred in cheatgrass in late April, 1993, and the lowest $(28.7 \%)$ was obtained from bluebunch wheatgrass in late October, 1993 (Fig. 3). Variability between years and corresponding months was greatest for Sandberg's bluegrass and lowest for giant wildrye (Fig. 3). Across years, months, and species, IVOMD was positively correlated with $\mathrm{CP}$ content $(\mathrm{r}=0.91, \mathrm{P}<$ 0.001 ). Annual and seasonal patterns visually approximated those obtained with $\mathrm{CP}$ concentrations. With the exception of
Thurber's needlegrass, IVOMD values began at lower levels in 1992 and ended the year at higher levels in 1992 than in 1993. As with CP, patterns of seasonal decline were curvilinear in 1993 and, with the exception of Sandberg's bluegrass, IVOMD decreased through late October.

The greatest range of seasonal change in IVOMD occurred with cheatgrass (1992) and giant wildrye (1993), while the smallest range of seasonal change was exhibited by Idaho fescue in 1992 and Thurber's needlegrass in 1993. Within forages and between years and months, variation in IVOMD was highest for Sandberg's bluegrass and lowest for giant wildrye.

Five of the 7 grasses (Thurber's needlegrass and giant wildrye excluded) responded to above average October precipitation $(57 \mathrm{~mm})$ in 1992 by significantly $(\mathrm{P}<0.05)$ increasing late-October IVOMD (Fig. 1). However, the $65 \mathrm{~mm}$ of rain that occurred in July of 1993 did not induce changes in any of the grasses.

\section{Neutral detergent fiber}

During both years, grass NDF increased in a manner typical of maturing forages (Fig. 4) in a Mediterranean environment. Among grasses, seasonal increase in NDF averaged about $18 \%$ and 27 percentage points for 1992 and 1993, respectively. The lowest NDF (38.5\%) occurred with cheatgrass in late April 1993, and the highest fiber level (80.9\%) was found with giant wildrye in late November 1992.

Within forages, variability between years and corresponding months was highest with cheatgrass and lowest with bluebunch wheatgrass and Thurber's needlegrass. All the grasses started the growing season with lower NDF levels in 1993 than in 1992; and with the exception of bluebunch wheatgrass and giant wildrye, end of the year NDF values were higher in 1993 than in 1992. October precipitation in 1992 induced green-up and a significant decrease in NDF for Sandberg's bluegrass, cheatgrass, and squirreltail. The July rainfall of 1993 had no effect on NDF of forages. Because fiber content of grasses increased as foliage matured and our other indices of forage quality (CP and IVOMD) declined with maturity, NDF dynamics were negatively correlated with $\mathrm{CP}(\mathrm{r}=-0.80)$ and IVOMD $(\mathrm{r}=-0.85)$.

\section{Discussion}

Although crop year precipitation (86\% of mean) contributing to forage growth in 1992 could not be defined as a drought 

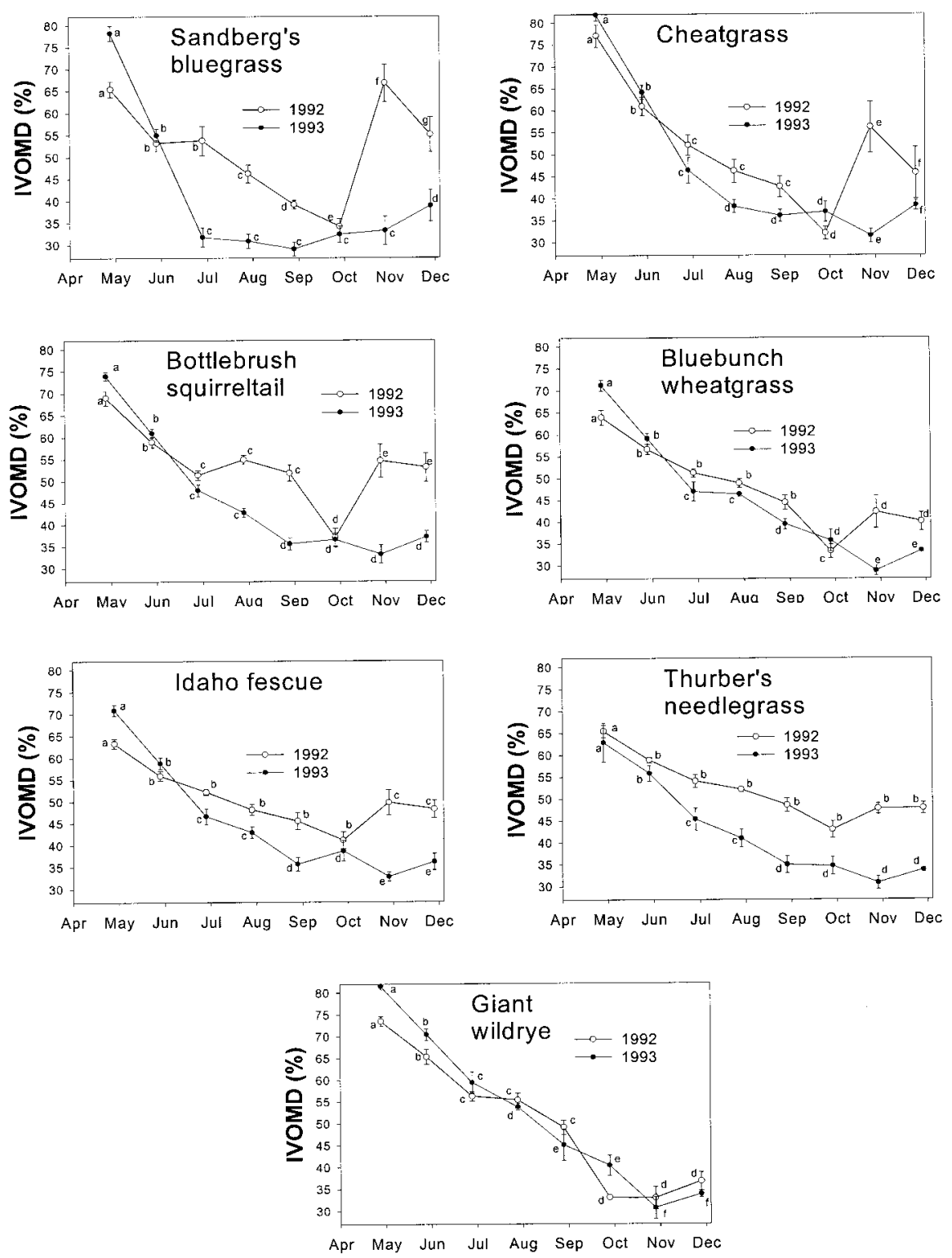

Fig. 3. Percent in vitro organic matter disappearance $( \pm \mathrm{SE})$ of 7 grasses sampled over 8 monthly intervals at 6 different sites in the sagebrush steppe near Burns, Ore. during 1992 and 1993. Adjacent means within a year sharing a common letter are not significantly different $(P>0.05)$. LSD $(P=0.05)=6.4$ for 1992 and 5.4 for 1993 .

(Society for Range Management 1974), perceptions among regional land and livestock managers were that forages and stock water were in short supply. In contrast, water and forage supplies were viewed as more than adequate in spring 1993. The disparity in herbage yields between these 2 years, estimated with Sneva's (1982) forage yield model (1992 $=542 \mathrm{~kg} \mathrm{ha}^{-1}$ and $\left.1993=1,257 \mathrm{~kg} \mathrm{ha}^{-1}\right)$ suggests those perceptions were justified.

From a nutritional standpoint, our forage quality assays imply those views might be reversed. Crude protein is only 1 of several important forage characteristics for however, CP levels are well correlated with many desirable plant components like digestibility, vitamins, calcium, and phosphorus. These all decline to deficient levels at about the same time, and CP serves as a reliable measure of overall nutritional value (Sullivan 1962). Also, we adopted a $7.5 \% \mathrm{CP}$ level as an adequate forage quality threshold because it falls within the range of values suggested for maintenance of many wild and domestic herbivores (French et al. 1955, Thorne et al. 1976, Schwartz et al. 1977, NRC 1978, 1981, 1984). rangeland herbivores. Among forages,
The greatest disparity between the 2 years was the length of time when adequate CP levels were available. During our sampling period (approximately 217 days each year) one or more of the forages supplied CP levels above $7.5 \%$ for about 185 days in 1992 and only 83 days in 1993 (Fig. 5). In other words during our sampling period, available forage was CP deficient for about 32 days (mid Septemberearly October) in 1992 and 134 days (late July-November) in 1993. Large herbivores typically harvest diets of higher quality than hand-compounded rations or wholeplant samples (Kiesling et al. 1969, McInnis and Vavra 1987, Cruz and Ganskopp 1998), so adequate CP concentrations probably extend for longer periods of time in applied situations.

Maintenance of a diversity of forages within pastures is important, especially when conditions are less than optimum. In 1992, Idaho fescue furnished herbage of at least $7.5 \% \mathrm{CP}$ for a total of 177 days while giant wildrye ranked second and yielded 172 contiguous days of herbage above $7.5 \%$ CP (Fig. 2). Bottlebrush squirreltail furnished adequate forage for a few days in early September, when Idaho fescue was deficient, and Sandberg's bluegrass responded to October precipitation and elevated fall forage quality more quickly than Idaho fescue (Fig. 2).

A diversity of forages did not offer the same advantages in 1993 that occurred in 1992, however. With abundant spring soil moisture in 1993, all of the grasses quickly advanced through maturity, and all herbage was deficient in CP by late July. The $64 \mathrm{~mm}$ of precipitation that occurred in July 1993 failed to sustain the green feed period or cause new tillers to develop among any of the grasses. In 1993, giant wildrye displayed the longest period ( 83 days) of adequate CP followed by Idaho fescue at 69 days.

Murray et al. (1978) monitored forage quality of 4 grasses included in our study (cheatgrass, giant wildrye, Sandberg's bluegrass, and bottlebrush squirreltail) through 7 growing seasons in southern Idaho. Their figures generally approximate the same second order response functions depicted by our 1993 data. They did not present specific annual patterns of precipitation within their illustrations, however, so we cannot relate seasonal variability in forage quality with annual precipitation dynamics (Murray et al. 1978).

We speculate the different response between years to summer precipitation is related to the growth and development patterns of cool-season, caespitose grass- 

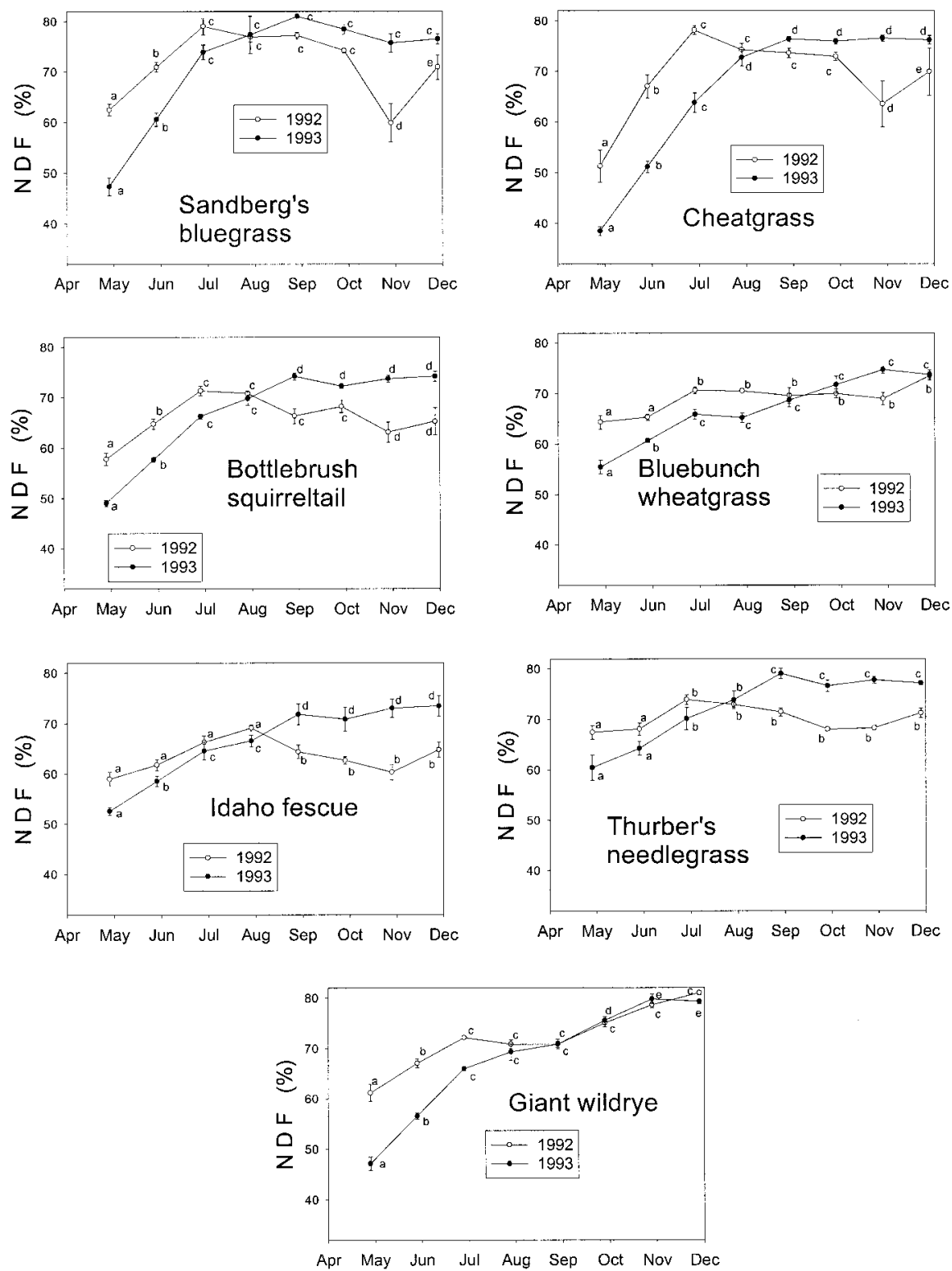

Fig. 4. Percent neutral detergent fiber $( \pm$ SE) of 7 grasses sampled over 8 monthly intervals at 6 different sites in the sagebrush steppe near Burns, Ore. during 1992 and 1993. Adjacent means within a year sharing a common letter are not significantly different $(P>0.05)$. $\operatorname{LSD}(P=0.05)=4.7$ for 1992 and 3.9 for 1993 .

es. Typically, tiller recruitment occurs in the fall. Individual tillers overwinter, extend leaves, differentiate, mature, and die during the subsequent growing season (Richards and Caldwell 1985, Mueller and Richards 1986, Olson and Richards 1988, Miller and Rose 1992). When spring moisture is abundant, nearly all tillers advance through maturity, and any new growth after mid-summer requires activation of new axillary buds. Some cool-season grasses actually enter summer dormancy and will not respond to midsummer moisture (Keller 1959, Hyder 1961). Field notes on our data sheets indicate a wealth of reproductive stems were generated in the 1993 growing season, and these probably contributed greatly to the rapid declines in CP and IVOMD and increases in NDF among all the grasses. Stems are typically lower in protein and digestibility than their accompanying leaves (Hacker and Minson 1981, Buxton and Marten 1989, Bidlack et al. 1999)

In 1992, spring soil moisture was not adequate to carry tillers to maturity. In response, adolescent tillers most likely became quiescent and then responded to June precipitation with renewed growth and a belated effort to reach maturity
(Hyder 1972). Because nearly all tillers reached maturity by mid-summer in 1993, there were few if any live stems that could capitalize on July precipitation.

Of the 4 grasses (Sandberg's bluegrass, cheatgrass, bottlebrush squirreltail, and Idaho fescue) that had significant $(\mathrm{P}<$ 0.05 ) increases in CP and IVOMD with 1992 fall precipitation, Sandberg's bluegrass was the highest with $16.4 \% \mathrm{CP}$ (Fig. 2) and 67\% IVOMD. Also, Sandberg's bluegrass was the only grass that displayed a significant $(\mathrm{P}<0.05)$ increase in CP during October 1993. Although Sandberg's bluegrass is small in stature, it is the first grass in the region to green in the spring. Sandberg's bluegrass supports a dense carpet of shallow fibrous roots, and it can readily respond to small amounts of mid-summer or fall precipitation (Sneva 1982). Though it is not known as a major contributor to the standing crop, its growth habits combine to make it a desirable species that can enhance diet quality. Consequently, several rangeland herbivores seek it out early in the growing season (Vavra and Sneva 1978).

The CP and NDF dynamics of cheatgrass, the only annual included in our study, closely mimicked those of Sandberg's bluegrass (Figs. 2, 3, and 4). Like Sandberg's bluegrass, cheatgrass is a source of early spring forage (Cook and Harris 1952) and, because it functions as a winter annual with fall germination (Stewart and Hull 1949), it can contribute immature, high quality herbage late in the grazing season. Cheatgrass is famous for its extreme year to year variation in yield (Hull 1949, Murray and Klemmedson 1968), and it also provided the fewest days of adequate CP of any of the grasses in both years of our study (74 days in 1992 and 36 days in 1993).

Bottlebrush squirreltail was distinguished by its marked responses to summer and fall precipitation (Fig. 2). Hyder (1972) suggested bottlebrush squirreltail frequently supports culmless vegetative tillers that may be able to respond and differentiate with favorable conditions through the summer. In many years we have observed bottlebrush squirreltail flowering throughout the growing season. It is an early succession and increaser species in the region (Daubenmire 1970), and its opportunistic growth pattern may allow it to expedite reproduction and colonization of disturbed sites.

A distinctive feature of giant wildrye was its minimal response, based on our indices, to summer or fall precipitation (Figs. 2, 3, and 4). Of the grasses sampled, 

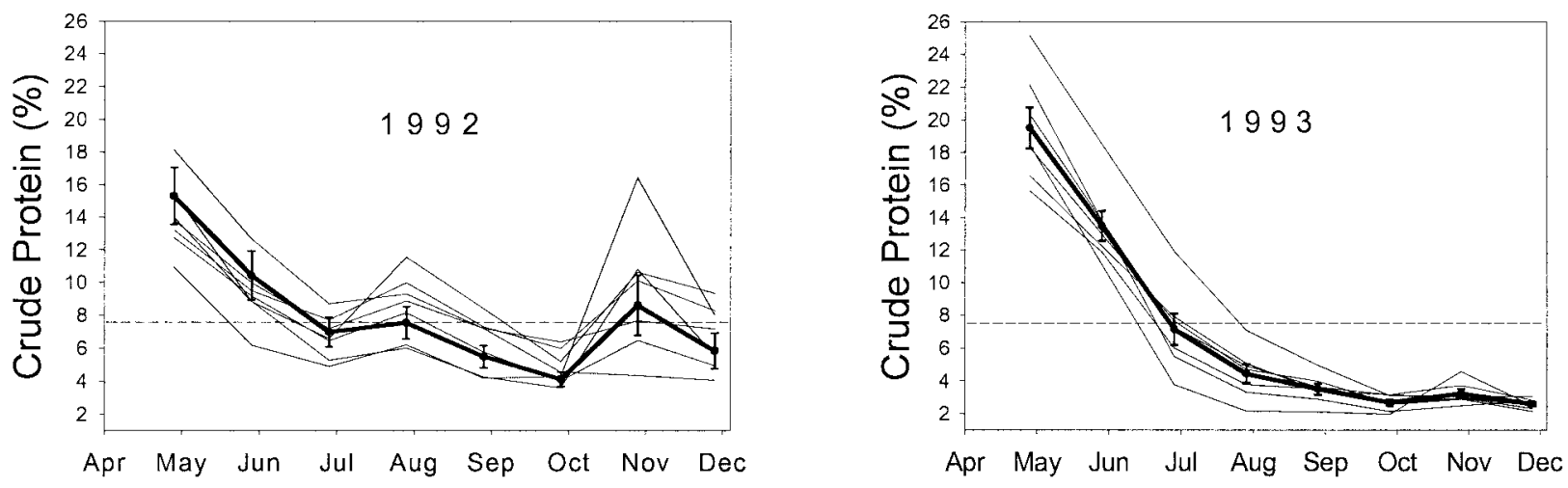

Fig. 5. Percent crude protein of 7 grasses (light lines) and the mean and SE (dark heavy line) across grasses sampled over 8 monthly intervals at 6 different sites in the sagebrush steppe near Burns, Ore. in 1992 and 1993. Dashed horizontal lines (- - - -) depict a 7.5\% CP level.

giant wildrye was the largest in stature, most deeply rooted, and last to emerge in spring. We suspect these growth habits combine to buffer it from minor environmental events that may affect more shallow rooted grasses during the growing season.

Although giant wildrye exhibited the lowest between year variation in IVOMD, bluebunch wheatgrass showed the least year-to-year variation with CP and NDF. Over an 18-year sampling period, Sneva (1982) also noted that yields of bluebunch wheatgrass were less variable than any of the other grasses in our study. When predicting annual forage yields with September-June precipitation accumulation as an independent variable, he obtained correlation coefficients ranging from 0.41 for Thurber's needlegrass to 0.84 for bluebunch wheatgrass (Sneva 1982). Highest coefficients of determination, however, were obtained when models estimated cumulative yield for all forages in the community (Blaisdell 1958, Sneva 1982).

\section{Conclusions}

Year-to-year patterns of forage quality in the northern Great Basin sagebrush steppe can be quite dynamic both within and among species. A growing season with less than average moisture may generate grass herbage that sustains a higher plane of nutrition for up to twice as many days as a growing season with abundant moisture and more than double the forage production. We suspect that when coolseason grasses begin growth with less than optimum moisture, tillers become quiescent as moisture is exhausted, and they can resume mid-summer growth if effective precipitation occurs. Conversely, when abundant moisture is available, cool season grasses quickly advance through maturity and generate an abundance of low quality reproductive stems. Subsequently, those tillers die, and the grasses enter a dormant stage where they do not respond to even elevated levels of summer precipitation.

We suggest that rangelands with a diversity of grasses, that exploit all levels of the soil profile, will provide adequate forage quality for longer time periods than pastures relying on a single species. All 7 grasses in our study supplied high quality forage in the spring, and a deeply rooted grass like giant wildrye can support high quality forage until late-July. Shallow rooted grasses like Sandberg's bluegrass, bottlebrush squirreltail, or the winter annual cheatgrass can quickly respond to midsummer or fall precipitation that has no effect on the more deeply rooted grasses, and furnish additional high quality herbage.

Finally, while annual yields of herbage are closely correlated with yearly and sometimes seasonal precipitation accumulations, forage quality dynamics are more complex and certainly affected by seasonal events. With most of the precipitation accumulation in the northern Great Basin occurring in the colder months, land and livestock managers can, with a fair degree of certainty, predict the yields of their pastures before turnout. With an abundance of moisture, managers commonly see a rapid and predictable deterioration of forage quality typical of an arid Mediterranean climate. The quandary arrives in years when moisture accumulations will not sustain the grasses through their full development and maturity. We have shown that timely precipitation may indeed expand the period of adequate forage quality for livestock or wildlife in those instances.

\section{Literature Cited}

AOAC. 1984. Official methods of analysis $\left(14^{\text {th }}\right.$ Ed.) Assoc. of Official Analytical Chem. Washington D.C.

AOAC. 1990. Official methods of analysis (1 $5^{\text {th }}$ Ed.) Assoc. of Official Analytical Chem. Arlington, Virg.

Bidlack, J.E., J.E. Vaughan, and C.L. Dewald. 1999. Forage quality of 10 eastern gamagrass [Tripsacum dactyloides $(\mathrm{L}.) \mathrm{L}$. genotypes. J. Range Manage. 52:661-665.

Blaisdell, J. P. 1958. Seasonal development and yield of native plants on the upper Snake River plains and their relation to certain climatic factors. U.S. Dept. Agr. Bull. 1190.

Buxton, D.R. and G.C. Marten. 1989. Forage quality of plant parts of perennial grasses and relationship to phenology. Crop Sci. 29:429-435.

Cook, C.W. and L.E. Harris. 1952. Nutritive value of cheatgrass and crested wheatgrass on spring ranges of Utah. J. Range Manage. 5:331-337.

Cruz, R. and D. Ganskopp. 1998. Seasonal preferences of steers for prominent northern Great Basin grasses. J. Range Manage. 51:557-565.

Daubenmire, R. 1970. Steppe vegetation of Washington. Washington Agr. Exp. Sta., College of Agr. Washington State Univ. Bull 62.

Fisher, R.A. 1966. The design of experiments. $8^{\text {th }}$ ed., Hafner, New York.

French, C.E., L.C. McEwen, N.D. Magruder, R.H. Ingram, and R.W. Swift. 1955. Nutritional requirements of white-tailed deer for growth and antler development. State College, Penn. Penn. Agr.. Exp. Sta. Bull. 600.

Ganskopp, D. 1988. Defoliation of Thurber needlegrass: herbage and root responses. J. Range Manage. 41:472-476.

Hacker, J.B. and D.J. Minson. 1981. The digestibility of plant parts. Herb. Abstr. 51:459-482.

Hironaka, M., M.A. Fosberg, and A.H. Winward. 1983. Sagebrush-grass habitat types of southern Idaho. Wildl. and Range Exp. Sta., Univ. of Idaho, Moscow. Bull 35. 
Hull, A.C. 1949. Growth periods and herbage productions of cheatgrass and reseeded grasses in southwestern Idaho. J. Range Manage. 2:183-186.

Hyder, D.N. 1961. Growth characteristics of crested wheatgrass in the big sagebrush-bluebunch wheatgrass province of southeastern Oregon. Ph.D. Thesis. Oregon State Univ., Corvallis, Ore.

Hyder, D.N. 1972. Defoliation in relation to vegetative growth, p. 305-317. In: V.B. Youngner and C.M. McKell (ed.), The biology and utilization of grasses. Academic Press, New York.

Keller, W. 1959. Breeding improved forage plants for western ranges. Grassl. 334-344.

Kiesling, H.E., A.B. Nelson, and C. H. Herbel. 1969. Chemical composition of tobosa grass collected by hand-plucking and esophageal-fistulated steers. J. Range Manage. 22:155-159.

McInnis, M.L. and M. Vavra. 1987. Dietary relationships among feral horses, cattle, and pronghorn in southeastern Oregon. J. Range Manage. 40:60-66.

Miller, R.F. and J.A. Rose. 1992. Growth and carbon allocation of Agropyron desertorum following autumn defoliation. Oecologia 89:482-486.

Mueller, R.J. and J.H. Richards. 1986. Morphological analysis of tillering in Agropyron spicatum and Agropyron desertorum. Ann. Bot. 58:911-921.

Murray, R.B. and J.O. Klemmedson. 1968. Cheatgrass range in southern Idaho: seasonal cattle gains and grazing capacities. J. Range Manage. 21:308-313.

Murray, R. B., H.F. Mayland, and P.J. Van Soest. 1978. Growth and nutritional value to cattle of grasses on cheatgrass range in southern Idaho. USDA For. Ser. Res. Pap. INT-199. Intermountain For. and Range Exp. Sta., Ogden, Utah.
N.O.A.A. (National Oceanic and Atmospheric Administrat. 1991-1994. Climatological data annual summary, Oregon 97-100:(13).

NRC. 1978. Nutrient requirements of domestic animals. No. 6. Nutrient requirements of horses. Nat. Acad. Sci., Nat. Res. Counc., Washington, D.C.

NRC. 1981. Nutrient requirements of domestic animals. No. 15. Nutrient requirements of goats. Nat. Acad. Sci., Nat. Res. Counc., Washington, D.C.

NRC. 1984. Nutrient requirements of domestic animals. No. 4. Nutrient requirements of beef cattle. Nat. Acad. Sci., Nat. Res. Counc., Washington, D.C.

Olson, B.E. and J.H. Richards. 1988. Annual replacement of tillers of Agropyron desertorum following grazing. Oecologia 76:1-6.

Petersen, R.G. 1985. Design and analysis of experiments. Marcel Dekker, Inc., New York.

Raleigh, R. J. 1970. Symposium on pasture methods for maximum production in beef cattle: manipulation of both livestock and forage management to give optimum production. J. Anim. Sci. 30:108-114.

Raleigh, R.J. and J.D. Wallace. 1965. Nutritive value of range forage and its effect on animal performance. Research in beef cattle nutrition and management. Special Report 189. Agr. Exp. Sta., Ore. State Univ., Corvallis, Ore.

Richards, J.H. and M.M. Caldwell. 1985. Soluble carbohydrates, concurrent photosynthesis and efficiency in regrowth following defoliation: a field study with Agropyron species. J. Appl. Ecol. 22:907-920.

Robertson, J.B., and P.J. Van Soest. 1981. The detergent system of analysis and its application to human foods, p. 123-158. In: W.P.T. James and O. Theander (Ed.) The Analysis of dietary fiber. Marcell Dekker, New York.
Schwartz, C.C., J.C. Nagy, and R.W. Rice. 1977. Pronghorn dietary quality relative to forage availability and other ruminants in Colorado. J. Wildl. Manage. 41:161-168.

Society for Range Management. 1974. A glossary of terms used in range management. Belke Printing Co., Denver, Colo.

Sneva, F.A. 1982. Relation of precipitation and temperature with yield of herbaceous plants in eastern Oregon. Int. J. Biometeor. 4:263-276.

Stewart, G. and A.C. Hull. 1949. Cheatgrass (Bromus tectorum L.)- an ecologic intruder in southern Idaho. Ecol. 20:394-399.

Sullivan, J.T. 1962. Evaluation of forage crops by chemical analysis: a critique. Agron. J. 54:511-515.

Thorne, E.T., R.E. Dean, and W.G. Hepworth. 1976. Nutrition during gestation in relation to successful reproduction in elk. J. Wild. Manage. 40:330-335.

Turner, H.A. and T. DelCurto. 1991. Nutritional and managerial considerations for range beef cattle production. Beef Cattle Nutr. 7:95-125.

Vavra, M. and F. Sneva. 1978. Seasonal diets of five ungulates grazing the cold desert biome, p. 435-437. In: D.N. Hyder (ed.), Proc. First Internat. Rangeland Cong., Soc. Range Manage. Denver, Colo.

Wallace, J.D., C.B. Rumburg, and R.J. Raleigh. 1961. Evaluation of range and meadow forages at various states of maturity and levels of nitrogen fertilization. West. Sec. Amer. Soc. Anim. Sci. Proc. 12:1-6. 


\title{
Influence of off-stream supplements on streambanks of riparian pastures
}

\author{
MICHAEL L. MCINNIS AND JAMES McIVER
}

Authors are associate professor, Dept. Rangeland Resources, Oregon State Univ. Agr. Program at Eastern Oregon Univ., One University Blvd., La Grande, Ore. 97850; and ecologist, Forestry and Range Sciences Laboratory, USDA Forest Service, 1401 Gekeler Lane, La Grande, Ore. 97850.

\begin{abstract}
Accelerated erosion of streambanks in grazed riparian pastures is of concern to land managers. We tested the hypothesis that providing cattle free-choice off-stream water and trace mineralized salt would lessen negative impacts of grazing on cover and stability of streambanks compared to pastures lacking these amenities, and may therefore reduce the potential of accelerated erosion. The study was conducted on Milk Creek at the Hall Ranch Unit of the Eastern Oregon Agricultural Research Center near Union, Ore. Three replications each of 3 grazing treatments were examined: (1) non-grazed control; (2) grazed with supplemental water and trace mineralized salt provided ("supplemented"); and (3) grazed with no supplemental water or salt ("nonsupplemented"). Each grazed pasture (approximately 12 ha) was stocked with cow-calf pairs for a mean stocking rate of 0.8 ha per AUM to achieve moderate grazing intensity of approximately $\mathbf{5 0 \%}$ utilization of key forages. Pastures were grazed for $\mathbf{4 2}$ consecutive days during each of 2 years (1996-1997) beginning midJuly. Estimates of streambank cover ("covered" or "uncovered") and stability ("stable" or "unstable") were taken before (June) and after (September) grazing by examining $0.5 \times 0.3 \mathrm{~m}$ plots placed on the greenline. Additionally, frequency of cattle hoof prints (number of plots with hoof prints/total number of plots) was measured as an indication of cattle presence in the greenline. Treatment effects were compared using one-way ANOVA. Streambank effects were consistent with observations of cattle distribution, with $26 \%$ of the streambank in supplemented pastures showing cattle presence (hoof prints), versus $31 \%$ for nonsupplemented pastures. Off-stream water and salt attracted cattle into the uplands enough to significantly $(p \leq 0.05)$ reduce development of uncovered and unstable streambanks from $9 \%$ in non-supplemented pastures to $3 \%$ in supplemented pastures. An "erosion index" indicated no significant $(\mathbf{p}<0.05)$ difference in potential accelerated streambank erosion between supplemented and non-supplemented pastures.
\end{abstract}

Key Words: grazing, greenline, water quality, livestock, offstream water

Research was funded in part by Project No. AW 95-102, Western Regiona SARE Program.

Oregon Agr. Exp. Sta. Tech. Paper No. 11673

Manuscript accepted 29 Dec. 00.

\section{Resumen}

La erosión acelerada de los bancos de las corrientes de las praderas ribereñas apacentadas es una preocupación para los manejadores de tierras. Nosotros probamos la hipótesis de que proveyendo agua al ganado fuera del área de la corriente y sal de minerales traza se aminorarian los impactos negativos del apacentamiento sobre la cobertura y estabilidad de los bancos de las corrientes comparado con potreros carentes de estas prácticas de manejo y por lo tanto se puede reducir el potencial de una erosión acelerada. Este estudio se condujo en el arroyo "Milk" en el "Hall Ranch Unit" del Centro Agrícola de Investigación del Este de Oregon cercano a Union, Oregon. Se examinaron tres repeticiones de 3 tratamientos de apacentamiento: (1) control sin apacentamiento, (2) apacentamiento con suplemento de agua y sal de minerales traza ("suplementado") y (3) apacentamiento sin suplemento de agua ni sal ("no-suplementado"). En cada potrero apacentado (aproximadamente $12 \mathrm{ha}$ ) se colocaron pares de vaca-cría para obtener una carga animal promedio de 0.8 ha por UAM para alcanzar una intensidad de apacentamiento moderada de aproximadamente el $50 \%$ de utilización de las especies forrajeras clave. Los potreros se apacentaron 42 días consecutivos cada año durante dos años (1996-1997) iniciando el apacentamiento a mediados de Julio. Se tomaron estimaciones de la cobertura del banco de la corriente ("cubierto" y "descubierto") y de la estabilidad ("estable" e "inestable") antes (Junio) y después (Septiembre) del apacentamiento, las estimaciones se realizaron examinando parcelas de $0.5 \times 0.3 \mathrm{~m}$ colocadas en la línea verde. Adicionalmente se midió la frecuencia de huellas de pezuña de ganado (número de parcelas con huellas/ número total de parcelas) como un indicador de la presencia del ganado en la línea verde. Los efectos de los tratamientos fueron comparados mediante ANOVA con un solo criterio de clasificación. Los efectos en los bancos de la corriente fueron consistentes con las observaciones de la distribución del ganado, el $26 \%$ de los bancos en potreros suplementados mostraron la presencia de ganado (huellas de pezuña) contra el $31 \%$ de los potreros no suplementados. El agua fuera de la corriente y la sal atrajeron al ganado alejándolo de la corriente los suficiente para reducir significativamente $(p \leq \mathbf{0 . 0 5})$ el desarrollo de bancos de corriente "descubiertos" e "inestables" de $9 \%$ en los potreros "no-suplementados" al $3 \%$ en los potreros "suplementados" Un "índice de erosión" indicó diferencia no significativa $(p<0$.05) en la erosión acelerada potencial entre los bancos de corriente de potreros "suplementados" y "no suplementados". 
Cattle management problems in the Intermountain Region are more often associated with improper distribution than abundance of livestock (Holechek et al. 1989). This is especially true in riparian areas where water and shade attract livestock during the hottest months (Stuth 1991). Roath and Krueger (1982) estimated $81 \%$ of forage used by livestock under a moderate stocking regime in an Intermountain riparian area came from a streamside meadow representing only $2 \%$ of the grazing area. In fact, several studies have shown wild ungulates and livestock use riparian areas disproportionately more than adjacent uplands (Gillen et al. 1984, Kauffman and Krueger 1984, Marlow and Pogacnik 1985). Disproportionate use is an important management issue because abundant evidence indicates heavy cattle grazing can cause deleterious effects on riparian habitats (Skovlin 1984, Larsen et al. 1998), including changes in streambank stability (Marlow et al 1987), increased sedimentation (Duff 1979), loss of riparian vegetation, stream widening and shallowing (Platts 1986). By comparison, there is far less information on ecological effects of moderate grazing, including the type of riparian use suggested by alternative grazing strategies such as deferred grazing, rest-rotation grazing, and off-stream water (Skovlin 1984, Larsen et al. 1998).

The work reported here was part of a larger study on the economics and environmental effects of a cattle dispersion management system in which off-stream water and trace mineralized salt was supplied in a controlled, replicated field experiment (Dickard 1998, Stillings 1998, Tanaka et al. 1999). Animals grazing riparian pastures with off-stream water spend significantly less time at the stream than those with no water trough (Miner et al. 1992, Godwin and Miner 1996, DelCurto et al. 1999). Can a shift in cattle distribution (toward uplands) result in reduced ecological impact on the riparian zone? Streambank cover and stability are 2 critical factors influencing water quality, water storage, stream channel morphology, erosion potential, and wildlife habitats in riparian areas (Kauffman and Krueger 1984, Platts 1986, Bohn 1986, Elmore and Kauffman 1994, Mosley et al. 1997). Our objective was to test the hypothesis that providing free-choice off-stream water and trace mineralized salt to cattle grazing riparian pastures would result in more stable streambanks with greater cover and may therefore be less prone to accelerated erosion than streambanks in riparian pastures lacking these amenities.

\section{Materials and Methods}

\section{Study Site}

The study was conducted on the Hall Ranch unit $\left(45^{\circ} 7^{\prime} 41^{\prime \prime N}, 117^{\circ} 42^{\prime} 45^{\prime \prime} \mathrm{W}\right)$ of the Eastern Oregon Agricultural Research Center, approximately $19 \mathrm{~km}$ southeast of Union, Ore. Mean annual precipitation is $66 \mathrm{~cm}$, with approximately $60 \%$ occurring as snow. Elevation ranges from 1,050 to 1,250 m. The Hall Ranch includes 2 distinct riparian zones: the larger on Catherine Creek, a tributary of the Grande Ronde River, and the smaller on Milk Creek, a tributary of Catherine Creek. The 109 ha study area included the entire riparian zone and adjacent uplands of Milk Creek as it passes through the Hall Ranch, a $2.4 \mathrm{~km}$ section beginning at a private boundary on the north and ending at Highway 203 a few hundred meters from its confluence with Catherine Creek. The study area was grazed lightly from midJuly to mid-August in each of 5 years (1991-1995) prior to beginning this study (1996) at an average rate of 1.8 ha per AUM (range 1.5-2.0 ha per AUM).

\section{Treatments}

In May 1996, nine pastures (experimental units) of similar area (approximately 12 ha) in 3 blocks were delineated along the $2.4 \mathrm{~km}$ reach of Milk Creek (Fig. 1). The blocks were established because of differ-

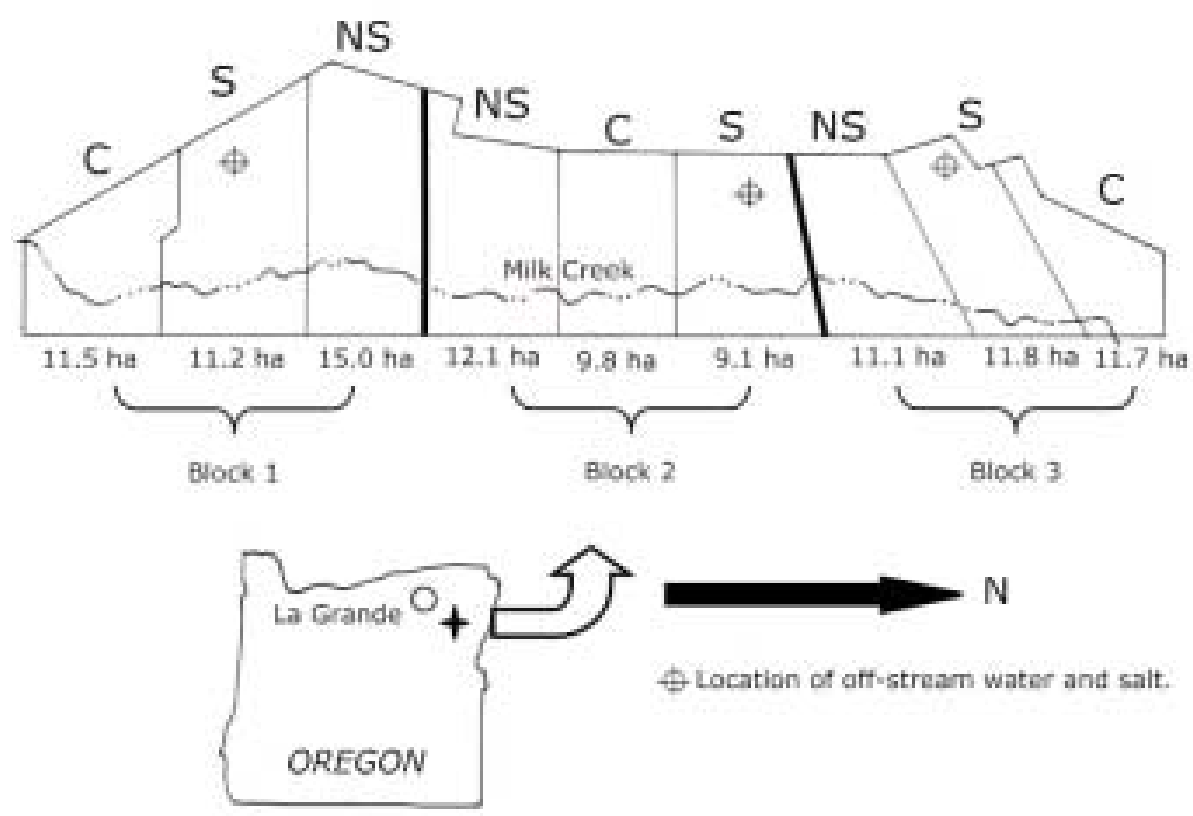

Fig. 1. Map of Milk Creek study area in northeastern Oregon showing block design, position and size (ha) of grazing treatments: $C=$ control (not grazed); $S=$ grazed, with supplements provided (free-choice off-stream water and trace mineralized salt); NS = grazed, with no supplements provided. ences in riparian habitat from the southern to northern section of Milk Creek. Block 1 was forested with Douglas hawthorn (Crataegus douglasii Lindl.) and ponderosa pine (Pinus ponderosa Dougl. Ex Loud.); Block 2 had components of both forest and meadow; and Block 3 was primarily meadow, dominated by Kentucky bluegrass (Poa pratensis L.), timothy (Phleum pratense L), sedges (Carex spp) and other dicots. Dominant riparian forages in all blocks were Kentucky bluegrass, sedges, timothy, meadow foxtail (Alopecurus pratensis L.), orchardgrass (Dactylis glomerata L.), and brome (Bromus spp.).The stream type (Rosgen and Silvey 1998) passing through Block 1 was predominately " $C$ " with a few (less than $10 \%$ ) inclusions of " $\mathrm{B}$ ". The channel substrate in Block 1 varied from cobble to sand. In Blocks 2 and 3 stream type was a complex of "C" and "E" with mostly sand substrate. Within blocks, slope was similar among treatment pastures and varied between $0-3 \%$ in riparian meadows and $12-35 \%$ in uplands. Three treatments were randomly assigned to pastures within each block beginning in 1996: (1) non-grazed control; (2) "supplemented" pastures, in which free-choice off-stream water and trace mineralized salt was provided; and (3) "non-supplemented" pastures, in which no off-stream water or salt was provided. The same treatments were assigned to pastures for both the 1996 and 1997 grazing 
seasons. Free choice off-stream water was provided in troughs to supplemented pastures approximately 366 linear meters upslope from Milk Creek. Feeders containing trace mineralized salt were placed about $4.5 \mathrm{~m}$ from the off-stream water sources. Water and salt were placed at the same locales in 1996 and 1997. For the 2 grazing treatments, $10 \mathrm{cow}$-calf pairs were introduced into each of the 6 pastures for 42 consecutive days beginning mid-July 1996 and 1997 for a mean stocking rate of 0.8 ha per AUM (range 0.8-0.9 ha/AUM), or a little more than twice the grazing intensity of the previous 5 years. The length of grazing time and stocking rate were chosen with the objective of achieving a moderate intensity of approximately $50 \%$ utilization of key forage species within each pasture. Actual utilization was measured using the method of Cassady (1941) by clipping vegetation at ground level in 15 pairs of $0.25 \mathrm{~m}^{2}$ circular plots placed at regular intervals from Milk Creek toward the uplands in each grazed pasture. Mean utilization averaged over the 2-year study was 31\% (range 23-43\%) in supplemented pastures and $47 \%$ (range $31-66 \%$ ) in non-supplemented pastures (Dickard 1998).

\section{Estimating Streambank Parameters}

Estimates of streambank cover and stability were made during the second grazing year (1997) using the method of Platts et al. (1983) as modified by Bauer and Burton (1993). Such a streambank alteration rating can provide an early warning system for changes caused by certain land uses, including grazing (Platts et al. 1987). Because the same treatment design was used for both years, estimating streambank variables in the second year allowed assessment of the cumulative effect of 2 consecutive years of treatment.

Streambanks were examined before (June) and after (September) cattle grazing by pacing the entire length of Milk Creek on both sides and recording the appropriate streambank cover and stability class within plots defined lengthwise as a step $(0.5 \mathrm{~m})$ taken parallel to the stream. Plot width (approximately $0.3 \mathrm{~m}$ ) was defined by the greenline, the first vegetation at the water's edge at or slightly below the bankful stage (Bauer and Burton 1993, Winward 2000). Each plot was first examined for the presence of hoof prints, defined as a clear impression of a hoof in soil or vegetation. Frequency (number of plots with hoof prints/total number of plots) was tallied for each treatment pasture.

The cover rating considered all organic and inorganic material that could provide protection from soil erosion. Plots were "covered" if they contained any of the following features: (1) living perennial vegetation ground cover greater than $50 \%$; or (2) roots of deeply-rooted vegetation such as shrubs or sedges covering more than $50 \%$ of the streambank; or (3) at least $50 \%$ of the streambank surface protected by rocks of cobble size or larger; or (4) at least $50 \%$ of the bank surface protected by logs of $10 \mathrm{~cm}$ diameter or larger (Bauer and Burton 1993). Otherwise streambanks were rated "uncovered". Cover estimates were based on visual assessment of the vertical projection of a polygon drawn around extremities of above-ground parts onto the ground (Daubenmire 1968). Platts et al. (1987) reported that streambanks rated more than $50 \%$ covered were stable or received only moderate alteration, while those rated $50 \%$ or less received major or severe alteration.

Streambanks were rated "unstable" if they exhibited any of these features: (1) blocks of banks broken away and lying adjacent to the bank breakage ("bank breakage"); (2) bank sloughed into stream channel ("slump"); (3) bank cracked and about to move into stream ("fracture"); (4) bank uncovered as defined above and exhibited an angle visually estimated steeper than 80 degrees from horizontal ("vertical bank") (Bauer and Burton 1993). Otherwise, streambanks were rated "stable".

Each step of the observer was thus rated according to streambank cover and stability, and grouped into 4 classes: (1) covered/stable; (2) covered/unstable; (3) uncovered/stable; and (4) uncovered/unstable. A single observer conducted the survey to avoid the variability of multiple observers reported by Platts et al. (1987).

Uncovered or unstable banks can lead to accelerated erosion (Marlow and Pogacnik 1985). To assess erosion potential of streambanks, an "erosion index" was calculated by first assigning a numerical score to each cover/stability class as follows:

$\begin{array}{lc}\text { Cover/Stability Class } & \text { Erosion Index } \\ \begin{array}{l}\text { covered/stable } \\ \text { uncovered/stable or } \\ \text { covered/unstable } \\ \text { uncovered/unstable }\end{array} & 2 \\ \text { nncor } & 3\end{array}$

The erosion index was then calculated for each treatment pasture:

Erosion Index $=\underline{\left(1 \mathrm{Xn}_{1}\right)+\left(2 \mathrm{Xn}_{2}\right)+\left(3 \mathrm{Xn}_{3}\right)}$

$$
\mathrm{N}_{\text {total }}
$$

where $n_{1-3}=$ number of plots with erosion index $1-3$, respectively and $\mathrm{N}=$ total number of plots/treatment pasture. The erosion index could vary from 1.0 (least erosion potential) to 3.0 (highest erosion potential). Plots rated 2.0 were vulnerable to erosion because they lacked either cover or stability.

\section{Statistical Analysis}

To test the hypothesis of grazing impacts on streambank cover and stability, data were summarized by treatment with 3 replicates (one per block) per treatment. Parameters examined were frequency of hoof prints; observed changes between June and September in each of the 4 cover/stability classes; and the erosion index. These parameters were analyzed using 1-way ANOVA with block $(\mathrm{n}=3)$ as a fixed factor and treatment $(\mathrm{n}=3)$ as the random factor (total $\mathrm{df}=8$ ). Means were compared using LSD ( $\mathrm{p} \leq 0.05)$.

\section{Results}

Following removal of cattle in September 1997, the percentage of streambank plots having cattle hoof prints averaged $0(\mathrm{SE} \pm 0), 26(\mathrm{SE} \pm 4)$ and $31(\mathrm{SE} \pm$ $5) \%$ in control, supplemented, and nonsupplemented pastures, respectively. While there was a trend ( $p>0.05)$ for supplemented pastures to have a lower frequency of hoof prints in the greenline compared to non-supplemented units, the 2 treatments did not differ statistically ( $\mathrm{p} \leq$ $0.05)$. Neither streambank cover nor stability differed significantly between supplemented and non-supplemented pastures (Table 1). However, compared to the nongrazed control, providing off-stream water and salt did prevent the significant loss of streambank cover observed in non-supplemented pastures.

Significant treatment effects on cover/stability classes of streambank plots included changes in proportions of the covered/stable, covered/unstable, and uncovered/unstable (Table 1). There were no block effects or block $\times$ treatment interaction effects in the proportion of change in cover/stability classes. The greatest change resulting from grazing, compared to non-grazed controls, was the significant decrease in the proportion of streambanks classified as covered/stable. Although non-supplemented pastures averaged $14 \%$ decrease in the covered/stable class, compared to $10 \%$ for supplementedpastures, the 2 grazing treatments did not differ statistically. The pattern of change, however, did differ between the 2 grazing treatments, with non-supplemented pastures gaining significantly $(\mathrm{p}<0.05)$ 
Table 1. Proportions of streambank class (m /100 m of streambank) before grazing (June), after grazing (September) and change, 1997. Change within streambank parameter with different superscripts are significantly different $($ lsd; $\mathbf{p}<0.05 ; \mathbf{n}=3)$.

\begin{tabular}{|c|c|c|c|c|c|c|c|c|c|}
\hline \multirow[t]{2}{*}{ Streambank Parameter } & \multicolumn{3}{|c|}{ Non-grazed Pastures } & \multicolumn{3}{|c|}{ Supplemented Pastures } & \multicolumn{3}{|c|}{ Non-supplemented Pastures } \\
\hline & Before & After & $\overline{\text { Change }}$ & Before & After & Change & Before & After & Change \\
\hline & $-\ldots$ & $-\cdots-$ & $-\ldots$ & $---(\mathrm{m} /$ & of strea & k) - - - - & $--\cdots$ & $-\cdots$ & $-\cdots--$ \\
\hline Covered & 92 & 92 & $0^{\mathrm{a}}$ & 94 & 90 & $-4^{a b}$ & 89 & 83 & $-6^{\mathrm{b}}$ \\
\hline Stable & 91 & 91 & $0^{\mathrm{a}}$ & 95 & 85 & $-10^{\mathrm{b}}$ & 93 & 76 & $-17^{\mathrm{b}}$ \\
\hline Covered/Stable & 90 & 90 & $0^{\mathrm{a}}$ & 89 & 79 & $-10^{\mathrm{b}}$ & 82 & 68 & $-14^{\mathrm{b}}$ \\
\hline Uncovered/Stable & 3 & 3 & $0^{\mathrm{a}}$ & 5 & 6 & $+1^{\mathrm{a}}$ & 10 & 8 & $-2^{\mathrm{a}}$ \\
\hline Covered/Unstable & 5 & 5 & $0^{\mathrm{a}}$ & 5 & 11 & $+6^{\mathrm{ab}}$ & 8 & 15 & $+7^{\mathrm{b}}$ \\
\hline Uncovered/Unstable & 2 & 2 & $0^{\mathrm{a}}$ & 1 & 4 & $+3^{b}$ & 0 & 9 & $+9^{c}$ \\
\hline Erosion Index & 1.18 & 1.18 & $0^{\mathrm{a}}$ & 1.10 & 1.23 & $+0.13^{\mathrm{b}}$ & 1.17 & 1.39 & $+0.22^{\mathrm{b}}$ \\
\hline
\end{tabular}

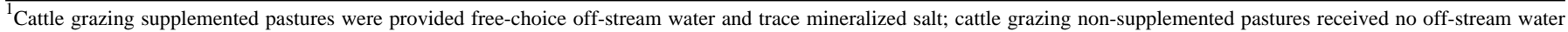
or salt supplement.

more of the uncovered/unstable class. Proportionally, there were larger changes in stability than cover resulting from grazing (Table 1). Therefore decreases in stability likely contributed more to change in the uncovered/unstable class than decreases in cover. This is further reflected by the fact that the uncovered/stable class did not change in relation to controls, while the covered/unstable class changed significantly. The bank instability factor contributing the largest proportion of change resulting from grazing per se was slumping of the bank into the stream channel (Table 2). There was a trend $(p>0.05)$ toward less stable banks in non-supplemented pastures compared to supplemented pastures, but streambank stability in the 2 grazed treatments did not differ statistically.

While erosion potential (reflected by the erosion index) increased significantly because of grazing, there was no significant difference in this metric between the 2 grazing strategies (Table 1) suggesting offstream water and salt supplement may not be helpful in preventing accelerated erosion.

\section{Discussion and Conclusions}

Grazing per se resulted in (1) decline in streambank stability, (2) decline in the covered/stable streambank class with concomitant increase in the uncovered/unstable class, and (3) increase in soil erosion potential. Previous work on this project indicated off-stream water and trace mineralized salt supplement attracted cattle toward uplands (Dickard 1998, DelCurto et al. 1999). This redistribution of livestock was enough to significantly $(\mathrm{p} \leq 0.05)$ reduce development of uncovered/unstable streambanks to $3 \%$ in supplemented pastures compared to $9 \%$ in non-supplemented pastures. Off-stream water and mineral supplements may be combined with other management tools to help keep livestock away from sensitive riparian areas. The degree to which livestock can be attracted away from riparian areas depends on season, topography, vegetation, weather and behavioral differences (Bryant 1982, Stuth 1991). For example, successful use of offstream water to adjust distribution late in the season may not be observed for early season grazing (Miner et al. 1992) because of changes in weather and forage quality. Pastures with steep slopes may be less amenable to provisioning with off-stream water (Bryant 1982, Dickard 1998). The relative quality of forage between riparian and upslope portions of a pasture may also be more important for determining livestock distribution patterns (Skovlin 1984). Finally, individual cattle can be expected to respond in a variety of ways, based on innate as well as learned behaviors (Bryant 1982, Skovlin 1984).

The observed decline in streambank stability and increase in erosion potential resulting from grazing in our study prompt the question: would the magnitude of these effects result in eventual changes in channel morphology or contribute to declines in native fish populations? The answers depend upon whether or not streambanks recover over the course of the year, and whether or not streambank slumping along Milk Creek created enough sediment to cause permanent changes in aquatic habitat quality. Several studies have reported significant channel morphology effects as a consequence of chronic, heavy livestock grazing (Marlow et al. 1987, Rinne 1988), but few have

Table 2. Mean proportions ( \pm SE) of streambanks $(\mathrm{m} / 100 \mathrm{~m}$ of streambank) in the various instability classes before grazing (June), after grazing (September) and change, 1997. Instability classes are "bank breakage" (B) in which blocks of banks are broken away and lying in the stream; "slump" (S) in which the bank has sloughed into stream channel; "fracture" (F) in which the bank has cracked and is about to move into the stream; and "vertical bank" $(V)$ in which the bank has an angle visually estimated steeper than 80 degrees from the horizontal (Bauer and Burton 1993). Change in bank instability classes among grazing treatments (columns) with different superscripts are significantly different (lsd; $\mathbf{p}<0.05 ; \mathbf{n}$ =3).

\begin{tabular}{|c|c|c|c|c|c|c|c|c|c|c|c|c|}
\hline \multirow[t]{2}{*}{ Grazing Treatment } & \multicolumn{4}{|c|}{ Before } & \multicolumn{4}{|c|}{ After } & \multicolumn{4}{|c|}{ Change } \\
\hline & B & $\mathrm{S}$ & $\mathrm{F}$ & $\mathrm{V}$ & B & $\mathrm{S}$ & $\mathrm{F}$ & V & B & $\mathrm{S}$ & $\mathrm{F}$ & V \\
\hline$\overline{-}$ & $\ldots$ & -- & $-\ldots$ & $-\ldots$ & ank In & lity $\mathrm{Cl}$ & $\mathrm{n} / 100 \mathrm{r}$ & strear & $-\ldots$ & $\ldots$ & $-\ldots$ & $\ldots \ldots$ \\
\hline $\begin{array}{l}\text { Non-grazed } \\
\text { Pastures }\end{array}$ & $\begin{array}{c}0 \\
( \pm 0)\end{array}$ & $\begin{array}{c}4 \\
( \pm 1)\end{array}$ & $\begin{array}{c}<1 \\
( \pm 1)\end{array}$ & $\begin{array}{c}5 \\
( \pm 2)\end{array}$ & $\begin{array}{c}0 \\
( \pm 0)\end{array}$ & $\begin{array}{c}4 \\
( \pm 1)\end{array}$ & $\begin{array}{c}<1 \\
( \pm 1)\end{array}$ & $\begin{array}{c}5 \\
( \pm 2)\end{array}$ & $\begin{array}{c}0 \\
( \pm 0)\end{array}$ & $\begin{array}{r}0^{\mathrm{a}} \\
( \pm 0)\end{array}$ & $\begin{array}{c}0 \\
( \pm 0)\end{array}$ & $\begin{array}{c}0 \\
( \pm 0)\end{array}$ \\
\hline $\begin{array}{l}\text { Supplemented } \\
\text { Pastures }\end{array}$ & $\begin{array}{c}1 \\
( \pm 1)\end{array}$ & $\begin{array}{c}0 \\
( \pm 0)\end{array}$ & $\begin{array}{c}0 \\
( \pm 0)\end{array}$ & $\begin{array}{c}4 \\
( \pm 1)\end{array}$ & $\begin{array}{c}2 \\
( \pm 1)\end{array}$ & $\begin{array}{c}9 \\
( \pm 3)\end{array}$ & $\begin{array}{c}0 \\
( \pm 0)\end{array}$ & $\begin{array}{c}4 \\
( \pm 1)\end{array}$ & $\begin{array}{c}+1 \\
( \pm 1)\end{array}$ & $\begin{array}{l}+9^{b} \\
(+5)\end{array}$ & $\begin{array}{c}0 \\
( \pm 0)\end{array}$ & $\begin{array}{c}0 \\
( \pm 0)\end{array}$ \\
\hline $\begin{array}{l}\text { Non-supplemented } \\
\text { Pastures }\end{array}$ & $\begin{array}{c}1 \\
( \pm 1)\end{array}$ & $\begin{array}{c}1 \\
( \pm 1)\end{array}$ & $\begin{array}{c}0 \\
( \pm 0)\end{array}$ & $\begin{array}{c}5 \\
( \pm 1)\end{array}$ & $\begin{array}{c}2 \\
( \pm 1)\end{array}$ & $\begin{array}{c}17 \\
( \pm 4)\end{array}$ & $\begin{array}{c}0 \\
( \pm 0)\end{array}$ & $\begin{array}{c}5 \\
( \pm 1)\end{array}$ & $\begin{array}{c}+1 \\
( \pm 1)\end{array}$ & $\begin{array}{l}+16^{\mathrm{b}} \\
( \pm 4)\end{array}$ & $\begin{array}{c}0 \\
( \pm 0)\end{array}$ & $\begin{array}{c}0 \\
( \pm 0)\end{array}$ \\
\hline
\end{tabular}

${ }^{\mathrm{T}}$ Cattle grazing supplemented pastures were provided free-choice off-stream water and trace mineralized salt; cattle grazing non-supplemented pastures received no off-stream water or salt supplement. 
attempted to follow recovery rates year to year, especially after moderate grazing intensity. Kauffman et al. (1983), working on a stream adjacent to Milk Creek (Catherine Creek), found that stocking rates of 1.3-1.7 ha/AUM (compared to 0.8 ha/AUM measured in our study) caused significantly greater bank erosion compared to non-grazed controls during 2 seasons of grazing. They also found that while over-winter erosion did not differ among treatments, livestock grazing was enough to cause an overall increase in streambank losses over the study period. Conversely, some authors suggest moderate streambank damage is mitigated by natural processes the following year. Buckhouse et al. (1981) reported that while moderate cattle grazing caused measurable streambank effects in a single season, any differences between grazed and non-grazed treatments were erased the following year by ice effects and peak flows for this study. While their experiment did not isolate cattle grazing effect per se, results underscore the difficulty in understanding the role of grazing for sediment production in the context of the annual cycle of sediment release. Similarly, Marlow et al. (1987) reported that streamflow and cattle use were both correlated with degree of change in stream channel profile. In particular, streambank alteration resulted from a combination of high soil moisture, high streamflow, and cattle use. Thus, cattle impacts could only be judged within the context of the annual cycle of natural events typical of their study site. In our study, the only observed changes in streambanks between June and September occurred in the grazed pastures (Tables 1 and 2). Flows in Milk Creek average about $0.5 \mathrm{~m}^{3} \mathrm{sec}^{-1}$ in early June, $0.1 \mathrm{~m}^{3} \mathrm{sec}^{-1}$ in early July and $0.6 \mathrm{~m}^{3} \mathrm{sec}^{-1}$ in mid-September. Under this flow regime, grazing-induced reductions in streambank cover and stability could result in accelerated erosion during high flows of the subsequent spring. In general, because at least 30 variables are involved in the sediment transport process (Heede 1980), few studies have isolated the effects of ungulate grazing from the natural background of erosion that occurs over the course of a year (Skovlin 1984). While these studies and others suggest that cattle grazing strategies can reduce impact on sensitive riparian areas, what is really needed are experiments that link cattle grazing intensity, streambank breakdown, sediment release, and instream habitat effects. Such studies are essential if we are to understand the thresholds beyond which cattle-induced streambank breakdown become a problem.

\section{Literature Cited}

Bauer, S.B. and T.A. Burton. 1993. Monitoring protocols to evaluate water quality effects of grazing management on western rangeland streams. USEPA 910/R-93-017, U.S. Environ. Protection Agency, Water Div., Region 10, Seattle, Wash.

Bohn, C. 1986. Biological importance of streambank stability. Rangelands. 8:55-56.

Bryant, L.D. 1982. Livestock response to riparian zone exclusion. J. Range Manage. 35:780-785.

Buckhouse, J.C., J.M. Skovlin, and R.W. Knight. 1981. Streambank erosion and ungulate grazing relationships. J. Range Manage. 34:339-340.

Cassady, J.T. 1941. A method of determining range forage utilization by sheep. J. Forage 39:667-671.

Daubenmire, R. 1968. Plant communities. Harper and Row, New York.

DelCurto, T., M. Porath, M. McInnis, P. Momont, and C. Parsons. 1999. Management strategies for optimal beef cattle distribution and use of mountain riparian meadows, p.119-129. In: K.L. Launchbaugh, J.C. Mosley and K.D. Sanders (eds.). Grazing behavior of livestock and wildlife. Idaho Forest., Wildl. and Range Exp. Sta. Bull. 70, Univ. Idaho, Moscow, Ida.

Dickard, M.L. 1998. Offstream water and salt as management strategies for improved cattle distribution and subsequent riparian health. M.S. Thesis, Univ. Idaho, Moscow, Ida.

Duff, D.A. 1979. Riparian habitat recovery on Big Creek, Rick County, UT., p. 91, In: Proc. Forum on grazing and riparian/stream ecosystems, Trout Unlimited, Vienna, Virg.

EImore, W. and J.B. Kauffman. 1994. Riparian and watershed systems: Degradation and restoration, p. 212-231. In: M. Vavra, W.A. Laycock, and R.D. Pieper (eds.) Ecological implications of livestock herbivory in the west. Soc. Range Manage., Denver, Colo.

Gillen, R.L., W.C. Krueger, and R.F. Miller. 1984. Cattle distribution on mountain rangeland in northeastern Oregon. J. Range Manage. 37:549-553.

Godwin, D.C. and J.R. Miner. 1996. The potential of off-stream livestock watering to reduce water quality impacts. Bioresources Tech. 58:285.

Heede, B.H. 1980. Stream dynamics: An overview for land managers. USDA For. Serv. Gen. Tech. Rep. RM-72. Rocky Mtn. For. and Range Exp. Sta., Ft. Collins, Colo.

Holechek, J.L., R.D. Pieper, and C.H. Herbel. 1989. Range management: Principles and practices, $2^{\text {nd }}$ ed., Prentice Hall, Upper Saddle River, N.J.

Kauffman, J.B. and W.C. Krueger. 1984. Livestock impacts on riparian ecosystems and streamside management implications: A review. J. Range Manage. 37:430-438.

Kauffman, J.B., W.C. Krueger, and M. Vavra. 1983. Impacts of cattle on streambanks in northeastern Oregon. J. Range Manage. 36:683-685.

Larsen, R.E., W.C. Krueger, M.R. George, M.R. Barrington, J.C. Buckhouse, and D.E. Johnson. 1998. Livestock influences on riparian zones and fish habitat: Viewpoint. J. Range Manage. 51:661-664.

Marlow, C.B. and T.M. Pogacnik. 1985 Cattle feeding and resulting patterns in a foothills riparian zone. J. Range Manage. 39:212-217.

Marlow, C.B., T.M. Pogacnik, and S.D. Quinsey. 1987. Streambank stability and cattle grazing in southwestern Montana. J. Soil and Water Conserv. 42:291-296.

Miner, J.R., J.C. Buckhouse, and J.A. Moore. 1992. Will a water trough reduce the amount of time hay-fed livestock spend in the stream (and therefore improve water quality)? Rangelands 14:35-38

Mosley, J.C., P.S. Cook, A.J. Griffis, and J. O'Laughlin. 1997. Guidelines for managing cattle in riparian areas to protect water quality: Review of research and best management practices policy. Idaho For., Wildl., Range Policy Analysis Group, Rep. 15. College Forest., Wildl. and Range Sci., Univ. Idaho, Moscow, Ida.

Platts, W.S. 1986. Riparian stream management. Trans. West Sect. Wildl. Soc. 22:90-93.

Platts, W.S., W.F. Megahan, and G.G. Minshall. 1983. Methods for evaluating stream, riparian and biotic conditions. USDA For. Serv., Gen. Tech. Rep. INT-138. Intermountain For. and Range Exp. Sta., Ogden, Ut.

Platts, W.S., C. Armour, G.D. Booth, M. Bryant, J.L. Bufford, P.Cuplin, S. Jensen, G.W. Lienkaemper, G.W. Minshall, S.B. Monsen, R.L. Nelson, J.R. Sedell, and J.S. Tuhy. 1987. Methods for evaluating riparian habitats with application to management. USDA For. Serv., Gen. Tech. Rep. INT-221. Intermountain Res. Sta., Ogden, Ut.

Rinne, J.N. 1988. Grazing effects on stream habitat and fishes: Research design considerations. No. Amer. J. Fish. Manage. 8:240-247.

Roath, L.R. and W.C. Krueger. 1982. Cattle grazing influence on a mountain riparian zone. J. Range Manage. 35:100-103.

Rosgen, D. and L. Silvey. 1998. Field guide for stream classification. Wildl. Hydro. Books, Pagosa Springs, Colo.

Skovlin, J.M. 1984. Impacts of grazing on wetlands and riparian habitats: A review, $\mathrm{p}$. 1001-1103. In: NRC/NAS, Developing strategies for rangeland management. Westview Press, Boulder, Colo.

Stillings, A.M. 1998. The economic feasibility of offstream water and salt to reduce grazing pressure in riparian areas. M.S. Thesis, Oregon State Univ., Corvallis, Ore.

Stuth, J.W. 1991. Foraging behavior, p. 65-83. In: R.K. Heitschmidt and J.W. Stuth (eds.), Grazing management: An ecological perspective. Timber Press, Portland, Ore.

Tanaka, J.A., N.R. Rimbey, and A.M. Stillings. 1999. Economics of grazing management in riparian areas, p. 10-18. In: E.T. Bartlett and L.W. Van Tassell (eds.). Grazingland economics and policy, Symp. Proc. Western Coordinating Committee on Range Econ. Colo. Agr. Exp. Sta., Colo. St. Univ., Ft. Collins, Colo.

Winward, A.H. 2000. Monitoring the vegetation resources in riparian areas. USDA Forest Serv. Gen. Tech. Rep. RMRS-GTR-47, Rocky Mtn. Res. Sta., Ogden, Ut. 


\title{
Frequency grid-a simple tool for measuring grassland establishment
}

\author{
KENNETH P. VOGEL AND ROBERT A. MASTERS
}

Authors are Research Geneticist and Rangeland Scientist, respectively, USDA-ARS, 344 Keim Hall, Univ. of Nebraska, P.O. Box 830937, Lincoln, Nebr. 68583-0937. Research is from USDA-ARS and University of Nebraska cooperative forage and range research programs affiliated with the Agronomy Department and the Center for Grassland Studies, University of Nebraska.

*Corresponding author. (Email:kpv@unlserve.unl.edu).

\begin{abstract}
Simple, reliable tools are needed by land managers to quantify establishment success when seeding or re-seeding pastures or rangeland. A frequency grid was designed to measure seedling or plant establishment success for a single species, mixtures of species, or single species of a mixture. The frequency grid is a metal frame containing 25 squares $(5 \times 5)$ or cells and can be made from concrete reinforcing sheets that have $15 \times 15 \mathrm{~cm}$ squares. When used, the frequency grid is either randomly or systematically placed within a seeded area. The number of cells containing 1 or more seeded plants are counted. The grid is then flipped, end-over-end, and the counts are repeated. The process is repeated until a total of $\mathbf{1 0 0}$ cells have been counted per sampling location within a seeded area. Counts can be directly converted into frequency of occurrence or stand percentages by dividing the number of cells that contain a seeded plant by 100 . The process can be repeated at several locations within a seeded area to characterize establishment success. Multiplying frequency of occurrence percentages by 0.4 provides a conservative estimate of plant density (plants $\mathrm{m}^{-2}$ ). A single measurement of 100 frequency grid cells can be taken in less than 5 minutes. The frequency grid is inexpensive to make, requires minimal training, permits rapid measurements, and provides a meaningful estimate of plant density. The frequency grid has been used to document herbicide efficacy and seeding rates for use in grassland establishment in the central Great Plains and should be easily adaptable for use in other geographic regions.
\end{abstract}

Key Words: planting, rangeland, pasture, plant density, seedling counts

Millions of hectares of land have been seeded to grasslands in the Great Plains and other western states. Additional land will likely be seeded in the future to convert marginal cropland to grasslands, upgrade existing seeded grasslands, and to restore degraded rangeland invaded by noxious weeds or damaged by fires. In addition, millions of hectares of pastures are periodically seeded in humid grassland areas worldwide. After each establishment attempt, the questions that managers must answer include: Was the seeding successful? Is the stand adequate for the intend-

Journal series no. 13201, Nebraska Agricultural Experiment Station.

Manuscript accepted 29 Dec. 2000.

\section{Resumen}

Los manejadores de tierras necesitan herramientas simples y confiables para cuantificar el éxito del establecimiento cuando se siembran o resiembran praderas o pastizales. Se diseño una cuadricula de frecuencia para medir el éxito del establecimiento de plántulas o plantas de una sola especie, mezclas de especies o una sola especie en una mezcla. La cuadrícula de frecuencia es un marco de metal que contiene 25 cuadros $(5 \times 5)$ o celdas y pueden ser hechas hojas para reforzar concreto que tienen cuadros de $15 \times 15$. Cuando se utiliza, la cuadrícula de frecuencia es colocada aleatoriamente o sistemáticamente dentro del área sembrada. Se cuenta el número de celdas que contienen 1 o más plantas sembradas. Entonces la cuadrícula se lanza y los conteos se repiten. Este proceso es repetido hasta que se ha contado un total de 100 celdas por localidad de muestreo en el área sembrada. Los conteos pueden ser directamente convertidos a frecuencias de ocurrencia o porcentajes dividiendo el número de celdas conteniendo una planta sembradas sobre 100 . El proceso puede ser repetido en varias localidades dentro del área sembrada para caracterizar el éxito del establecimiento. La multiplicación de los porcentajes de frecuencia de ocurrencia por 0.4 provee una estimación conservadora de la densidad de plantas (plantas $\mathrm{m}^{-2}$ ). Una sola medición de 100 celdas de la cuadrícula de frecuencia puede ser tomada en menos de 5 minutos. La construcción de la cuadrícula de frecuencia es barata, requiere de entrenamiento mínimo, permite medidas rápidas y provee una estimación significativa de la densidad de plantas. La cuadrícula de frecuencia ha sido utilizada para documentar la eficacia de herbicidas y dosis de siembra para su uso en el establecimiento de pastizales en las Grandes Planicies centrales y debe ser fácilmente adaptable para su uso en otras regiones geográficas.

ed purpose? If not, do only portions of the seeded area need to be planted again? Because of these questions, managers need tools to quantify the success of grassland plantings and not be forced to rely on visual evaluations.

The goal of all grassland re-vegetation is to obtain an acceptable number of established plants of the desired, seeded species per unit of land (i.e., density) which is often expressed as plants $\mathrm{m}^{-2}$. To be of most value, the plant density measurement also should provide an estimate of plant distribution over the unit area. Methods that have been developed to determine plant density and species composition in grasslands include density per quad- 
rant, 10-point frame, line point, line intercept, and visual estimates (Cook and Stubbendieck 1986, Bonham 1989). Visual estimates can vary widely depending on the experience and qualifications of the person making the estimate and can be unreliable. The other methods have been widely used in research but require a certain level of training and experience plus they are physically demanding because time is spent on one's hands and knees or bent over. The 10-point frame, line point, and line intercept methods do not provide direct measurement of plant density. Plant density per quadrant does provide direct measurement of plants per unit area but requires a considerable amount of skilled labor since all plants in a quadrant are usually identified and counted.

Here we describe a simple tool, the frequency grid, that we have used in our research to study seeding rates, herbicide efficacy, and rangeland and pasture improvement strategies. Frequency is the presence or absence in a sampling unit calculated as a percentage (Cook and Stubbendieck 1986, Bonham 1989). Advantages associated with this variable are that it is quick and easy to measure since only the presence or absence (yes or no) of a plant is recorded and it combines density and dispersion characteristics.

\section{Materials and Methods}

The frequency grid is a metal frame containing 25 squares $(5 \times 5)$ or cells and can be made from concrete reinforcing sheets that have $15 \times 15 \mathrm{~cm}$ squares (Fig. $1)$. We recently purchased a concrete rebar sheet of 4 gauge steel measuring $2.4 \times 6.1$ $\mathrm{m}$ with $15 \mathrm{~cm}$ squares for US $\$ 35.00$. We cut 12 grids from the single sheet for a materials cost of $\$ 3.00$ per grid. The grids can be used as is or can be painted to make the bars within the grid more distinctive for field use.

When used, the frequency grid is either randomly or systematically placed within a seeded area. The number of cells containing 1 or more seeded plants is counted. The grid is then flipped, end-over-end, and the counts are repeated. The process is repeated 3 times until a total of 100 cells have been counted per sampling location within a seeded area. Counts can be directly converted into frequency of occurrence or stand percentages by dividing the number of cells that contain a seeded plant by 100. Systematic placement can be used on small plots so that similar areas of each plot are measured while random place- ment is more suitable for larger areas. The process can be repeated at several locations within a seeded area to characterize establishment success of the entire area. Frequencies can be determined for single species by obtaining separate counts by species. Frequency measurements can be made after seedling emergence, at the end of the growing season the establishment year, following spring green up the year after establishment, or at several different times. The person making the counts has to be able to identify the seeded species. Since the total area covered by 4 grid units is $2.25 \mathrm{~m}^{2}$, multiplying frequency of occurrence percentages by 0.4 provides a conservative estimate of plants per $\mathrm{m}^{2}(1$ $\mathrm{m}^{2} / 2.25 \mathrm{~m}^{2}=0.44$ or approximately 0.4 ).

In the example shown in Fig. 1A, 18 cells have a seeded grass plant and assuming that when flipped end-over-end and counted 3 more times (not shown), the number of cells with 1 or more seeded grass plants was 17,15 , and 20 for a total
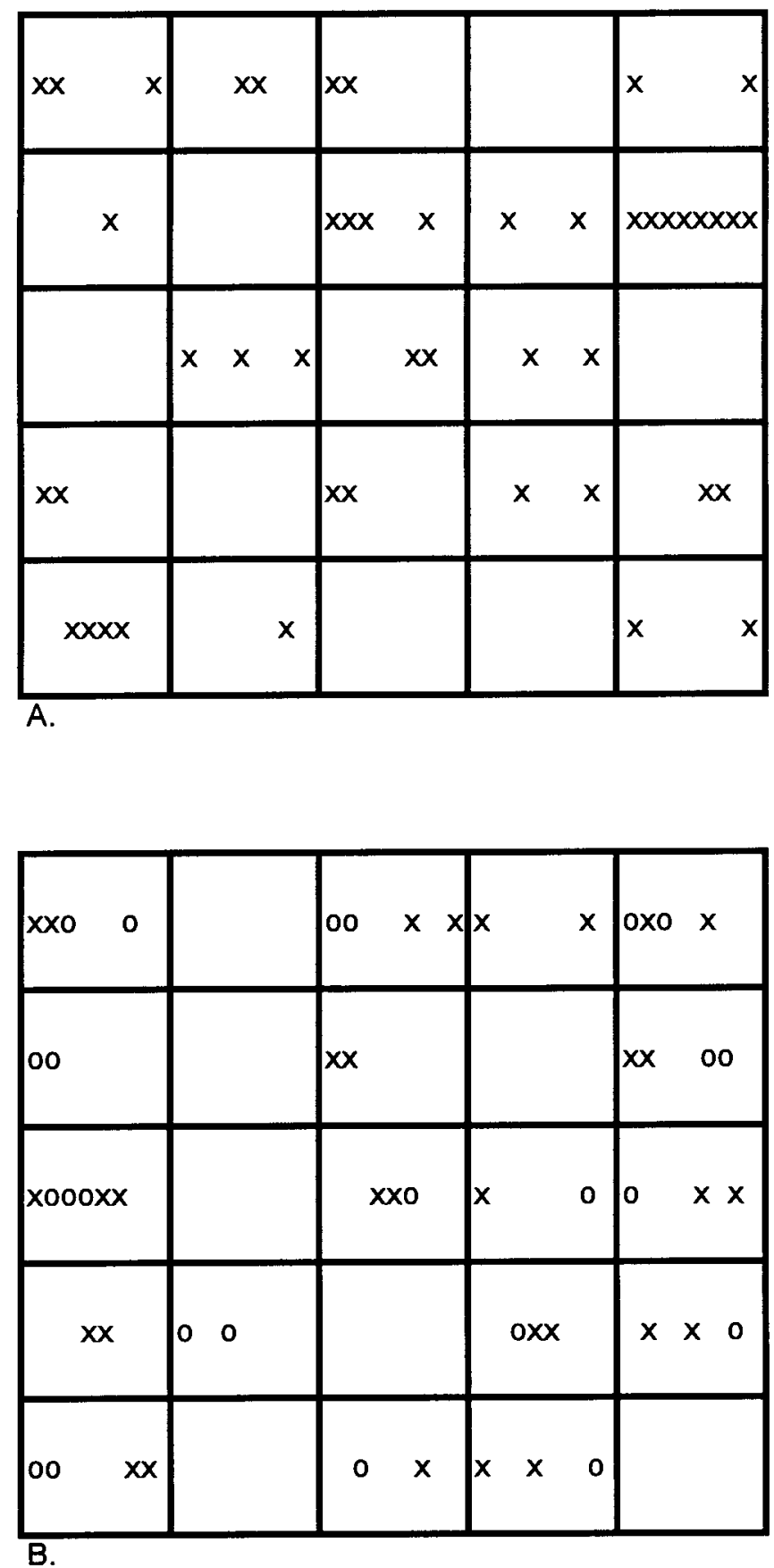

Fig. 1. Frequency grid examples where $x=$ grass plant and $o=$ forb or legume. 
of 70. Frequency of occurrence would be $70 / 100$ or $70 \%$ which when multiplied by 0.4 would give an estimate of 28 plants $\mathrm{m}^{-2}$. In the grass-forb seeding example shown in Fig. 1B, the number of cells with 1 or more seeded grass plants is 16 while cells with seeded forbs is 15 . Assuming that the grid is flipped end-over-end and counted three more times (not shown), the number of cells with seeded grasses was 18, 20, and 14 for a total of 68 while the number of forbs was 12, 14, and 19 for a total of 60 . The frequency for grasses and forbs would be 68 and $60 \%$, respectively. Density of grasses and forbs would be conservatively estimated as 27 and 24 plants $\mathrm{m}^{-2}$, respectively. Total plant frequency of occurrence could also be determined by counting the number of cells that contained either a seeded grass or forb.

\section{Results and Discussion}

The frequency grid is inexpensive, easy to make and use, and requires no "knee time". Once trained to identify the planted species, it is fast, reliable, and accurate. Stand frequencies can be routinely obtained on a single plot in less than 5 minutes. The Least Significant Differences or LSD's for stand frequency from our research trials are often about 10 to $15 \%$ (Vogel 1987, Masters et al. 1996, Masters 1997, Masters and Nissan 1998). The same level of reliability has been used to obtain stand frequencies in pastures (Bauer et al. 1996). This technique can be used to monitor establishment of single or multiple species. The success rate for individual species within a mixture can also be determined.

The frequency grid is essentially a quadrant that has been subdivided into 25 cells. Its use is based on the premise that, in establishment of grasslands, there are threshold densities of plants in a quadrant and that it is not necessary to count every plant. Multiplying the frequency of occurrence by 0.4 provides a conservative estimate of the number of plants $\mathrm{m}^{-2}$ because only a single count is made per grid cell even though a cell may contain several plants. In the Great Plains, it is possible to use this conservative estimate of plant density to determine if a planting is successful. Cornelius (1944) reported that 20 established plants $\mathrm{m}^{-2}$ would give a stand similar to that of native Great Plains prairie. Launchbaugh (1966), in a stand establishment survey of over 3,000 grass seedings in the Great Plains, classified plantings with 10 or more seedlings $\mathrm{m}^{-2}$ as good stands. In a designed study at Hays, Kan., Launchbaugh and Owensby (1970) determined that establishment-year densities of 20 to 30 plants $\mathrm{m}^{-2}$ of native grasses, including big bluestem (Andropogon gerardii Vitman) and switchgrass (Panicum virgatum L.), were generally ready to be grazed the following year.

Research by Vogel (1987) and Masters (1997) using the frequency grid demonstrated that switchgrass or big bluestem plots with a frequency of occurrence of $40 \%$ or more $\left(16\right.$ plants $\left.\mathrm{m}^{-2}\right)$ did not differ in forage yield the first or second year after establishment. In these studies, frequency of occurrence ranged from 27 to $94 \%$. Plots with initial frequencies as low as $30 \%$ (12 plants $\left.\mathrm{m}^{-2}\right)$ produced lower yields the first year after establishment but, by the second year after establishment, yields were equivalent to plots with higher initial frequencies of occurrence. These results, when combined with the previous research by Cornelius (1944), Launchbaugh (1966) and Launchbaugh and Owensby (1970), indicate that in the Great Plains, frequency grid values of $50 \%$ or higher (20 or more plants $\mathrm{m}^{-2}$ ) would be classified as fully successful stands, frequencies of 25 (10 plants $\left.\mathrm{m}^{-2}\right)$ to $50 \%$ would indicate marginal to adequate stands while stands of less than $25 \%$ could be regarded as requiring partial re-establishment or unsuccessful.

We have used the frequency grid to determine seeding rates that are needed to establish grasses when pre- or post-emergence herbicide treatments are used to control weeds (Vogel 1987, Masters 1997) and to assess rangeland and pasture improvement strategies (Masters et al. 1996, Masters and Nissan 1998). Data derived from these studies has been used to register herbicides for use in non-cropland, rangeland, and pastures. Grassland plantings can be made using drills that vary in distance between the seeding units, by broadcasting, or several other methods of seed application. Since the frequency grid measures frequency of occurrence on a unit area basis, it can be used to measure establishment for any planting method.

Although, we have used the frequency grid only on Great Plains grasslands, it should be readily adaptable for use in other geographical regions. Research will be needed to correlate frequencies of occurrence to other methods that have been used to measure stand establishment and grassland productivity following establishment. In summary, the frequency grid is a reliable, accurate, rapid, and inexpensive method that can be used to quantify the success of a grassland planting.

\section{Literature Cited}

Bauer, D., K.P. Vogel, and L.E. Moser. 1996. Grazing evaluation of cool-season grasses in the Nebraska Sandhills in replicated ranch trials. Soc. Range Manage. Annu. Meeting Abst. p. 6-7.

Bonham, C.D. 1989. Measurements for terrestrial vegetation. John Wiley \& Sons, N.Y.

Cook, C.W. and J. Stubbendieck. 1986. Range research: Basic problems and techniques. Soc. Range Manage. Denver, Colo.

Cornelius, D.R. 1944. Revegetation in the tallgrass prairie region. J. Amer. Soc. Agron. 36:393-400.

Launchbaugh, J.L. 1966. A stand establishment survey of grass plantings in the Great Plains. Nebraska Agric. Exp. Stn. Great Plains Counc. Publ. 23.

Launchbaugh, J.L. and C.E. Owensby. 1970. Seeding rate and first-year stand relationships for six native grasses. J. Range Manage. 23:424-417.

Masters, R.A. 1997. Influence of seeding rate on big bluestem establishment with herbicides. Agron. J. 89:947-951.

Masters, R.A. and S.J. Nissen. 1998. Revegetating leafy spurge (Euphorbia esula L.)-infested grasslands with native tallgrasses. Weed Technol. 12:381-390.

Masters, R.A., S.J. Nissen, R.E. Gaussoin, D.D. Beran, and R.N. Stougaard. 1996. Imidazolinone herbicides improve restoration of Great Plains grasslands. Weed Technol. 10:392-403.

Vogel, K.P. 1987. Seeding rates for establishing big bluestem and switchgrass with preemergence atrazine applications. Agron. J. 79:509-512. 


\title{
Suppression of annual bromes impacts rangeland: Vegetation responses
}

\author{
MARSHALL R. HAFERKAMP, R.K. HEITSCHMIDT, ELAINE E. GRINGS, MICHAEL D. MACNEIL, \\ AND MICHAEL G. KARL
}

Authors are rangeland scientist, supervisory rangeland scientist, research animal scientist, research geneticist, and postdoctoral rangeland scientist USDAARS, Fort Keogh Livestock and Range Res. Lab., Miles City, Mont. 59301. Karl is currently rangeland management specialist, USDI-Bureau of Land Management, Washington, DC 20240.

\begin{abstract}
Presence of invading annual bromes (Bromus spp.) can alter seasonal patterns of forage production and quality and require management changes for efficient use of infested rangelands in the Northern Great Plains. We studied biological impacts of the presence of brome by comparing brome infested rangeland to similar sites in which brome had been suppressed with autumn applications of atrazine [6-chloro-N-ethyl-N'-(1-methylethyl)1,3,5-triazine-2,4-diamine] at $0.56 \mathrm{~kg} \mathrm{ha}^{-1}$ in 1992 and 1993. Each treatment was randomly assigned to three, 12-ha pastures. Vegetation was measured for 5 months (May to September) each year from 1993 to 1995. Each pasture was stocked with 8 crossbred steers (Bos taurus) from mid-May to mid-September 1993 and 1995 and to mid-August 1994. The forage base varied temporally by date and year, but generally was not less than $800 \mathrm{~kg} \mathrm{ha}^{-1}$. Brome suppression increased $(P \leq \mathbf{0 . 0 5})$ crude protein concentration for western wheatgrass (Pascopyrum smithii Rydb. [Love]) in July (7.1 vs. 9.1\%) and August (6.0 vs. $7.1 \%)$. With the variation in annual brome stands among years, as influenced by growing conditions, this experiment demonstrated that improvement in forage nutritional quality can be expected from suppression of annual bromes on semiarid rangelands.
\end{abstract}

Key Words: Bromus japonicus, Pascopyrum smithii, Northern Great Plains, standing crop, forage quality

Japanese (Bromus japonicus Thunb.) and downy brome (Bromus tectorum L.) have invaded thousands of hectares of Northern Great Plains rangeland over the past 30 years (Haferkamp et al. 1993, Whisenant 1990, Hewlett et al. 1981). Although annual bromes can produce large quantities of nutritious spring forage, they can have a negative impact on associated perennial forage species, such as western wheatgrass (Pascopyrum smithii Rydb. [Love]; Haferkamp et al. 1997, 1998,

The authors express appreciation to Bryon Bennett, Caralee Leidholt, Cheryl Murphy, Duane Bundy, and several summer aides for field assistance, and Mary Ellen French for assistance with graphics.

This paper is a contribution from the USDA-ARS and Montana Agr. Exp. Sta., Miles City, Mont.

USDA-ARS Northern Plains Area, is an equal opportunity/affirmative action employer, and all agency services are available without discrimination.

Manuscript accepted. 20 Jan. 2001.

\section{Resumen}

La presencia de "Bromos" anuales invasores (Bromus spp.) puede alterar los patrones estacionales de producción y calidad de forraje y requieren cambios de manejo para hacer un uso eficiente de los pastizales infestados de las Grandes Planicies del Norte. Estudiamos los impactos biológicos de la presencia del "Bromo"mediante la comparación de pastizales infestados con sitios similares en los cuales el "Bromo" había sido suprimido con aplicaciones en otoño de atrazina [6-cloro-N-etil-N'-(1-metiletil)1,3,5-triazina-2,4-diamina] en dosis de $0.56 \mathrm{~kg} \mathrm{ha}^{-1}$ efectuadas en 1992 y 1993. Cada tratamiento se asignó aleatoriamente a tres potreros de 12 ha. De 1993 a 1995 la vegetación se midió anualmente durante 5 meses (Mayo a Septiembre). En 1993 y 1995, de mediados de Mayo a mediados de Septiembre, cada potrero se cargó con 8 novillos de cruzas comerciales (Bos taurus) y en 1994 se utilizaron hasta mediados de Agosto. El forraje base varió temporalmente por fecha y año, pero generalmente no fue menor de $800 \mathrm{~kg} \mathrm{ha}^{-1}$. La supresión de "Bromo" incrementó $(\mathrm{P} \leq \mathbf{0 . 0 5})$ la concentración de proteína cruda del "Western wheatgrass" (Pascopyrum smithii Rydb. [Love]) en Julio (7.1 vs. 9.1\%) y Agosto (6.0 vs. $7.1 \%)$. Con la variación entre años de las poblaciones de "Bromo", por influencia de las condiciones durante el período de crecimiento, este experimento demostró que al suprimir el "Bromo" anual se puede esperar un mejoramiento en la calidad nutricional de los pastizales semiáridos.

Rummell 1946), and performance of grazers (Mosley 1996, Mayland et al. 1994, Fleming et al. 1942).

Annual forage production on brome infested rangelands fluctuates greatly with variations in amounts and distribution of precipitation (Haferkamp et al. 1993, Gartner et al. 1986) and soil N (McLendon and Redente 1994, Cline and Rickard 1993). Forage nutritional quality of annual bromes is comparable to that of perennial grasses at similar phenological stages. But, because annual bromes mature quickly (Vallentine and Stevens 1994), their presence can alter seasonal patterns of forage production and quality (Haferkamp et al. 1994) on infested rangelands.

We studied the biological impacts of the presence of brome by comparing brome infested rangeland to similar sites on which brome had been suppressed. Our hypothesis was that by suppressing annual brome forage production we would enhance perennial grass production and alter inter-seasonal forage quality dynamics. 


\section{Materials and Methods}

\section{Study Site}

Research was conducted at the Fort Keogh Livestock and Range Research Laboratory $\left(46^{\circ} 22^{\prime} \mathrm{N} 105^{\circ} 5^{\prime} \mathrm{W}\right)$ near Miles City, Mont. Elevation ranges from 716 to $853 \mathrm{~m}$. Regional topography ranges from rolling hills to broken badlands with small intersecting ephemeral streams flowing into rivers in broad, nearly level valleys. Indigenous vegetation on the 22,500-ha research station is a $\mathrm{grama-needle} \mathrm{gras} \mathrm{s-wheatgras} \mathrm{s}$ (Bouteloua-Stipa-Agropyron) mix (Kuchler 1964). Annual precipitation averages 343 mm, with about $60 \%$ received from April through September (Fig. 1). Daily temperatures range from $>38^{\circ} \mathrm{C}$ during summer to $<-40^{\circ} \mathrm{C}$ during winter. The average frost-free growing season is 150 days.

Soils at the specific study site are a composite of Absher heavy clays (Fine, smectitic, frigid Leptic Torrertic Natrustalfs) and Gerdrum silty clay loam (Fine, smectitic, frigid Torrertic Natrustalfs). Topography is gently sloping $(<2 \%)$. Vegetation is dominated by western wheatgrass, blue grama (Bouteloua gracilis [H.B.K.] Lag. ex Griffiths), Sandberg bluegrass (Poa secunda Presl.), sand dropseed (Sporobolus cryptandrus [Torr.] Gray), and Japanese brome. Threadleaf sedge (Carex filifolia Nutt.) is the dominant grasslike species. Dandelion (Taraxacum officinale Weber) and salsify (Tragopogon dubius Scop.) are the dominant forb species.

\section{Treatments and Experimental Design}

Six, 12-ha pastures treated with the Range Improvement Machine in 1982 (Haferkamp et al. 1993) were used in this study. Each of 2 brome treatments was randomly assigned to 3 pastures in autumn 1992. The treatments were (1) brome undisturbed and (2) brome suppressed with atrazine [6-chloro-N-ethyl-N'-(1methylethyl)-1,3,5-triazine-2,4-diamine] applied to dormant vegetation in November 1992 and 1993 at $0.56 \mathrm{~kg}$ a.i. $\mathrm{ha}^{-1}$. Herbicide was applied by ground in 1992 in 149.6 liters water $\mathrm{ha}^{-1}$ and by air in 1993 in 18.7 liters water ha' ${ }^{-1}$. No herbicide was applied in autumn 1994.

Each 12-ha pasture was stocked annually with 8 crossbred yearling steers (Bos taurus). Pastures were stocked continuously from mid-May until mid-September 1993 and 1995. Limited forage production in 1994 resulted in a shortened grazing season extending from mid-May to mid-
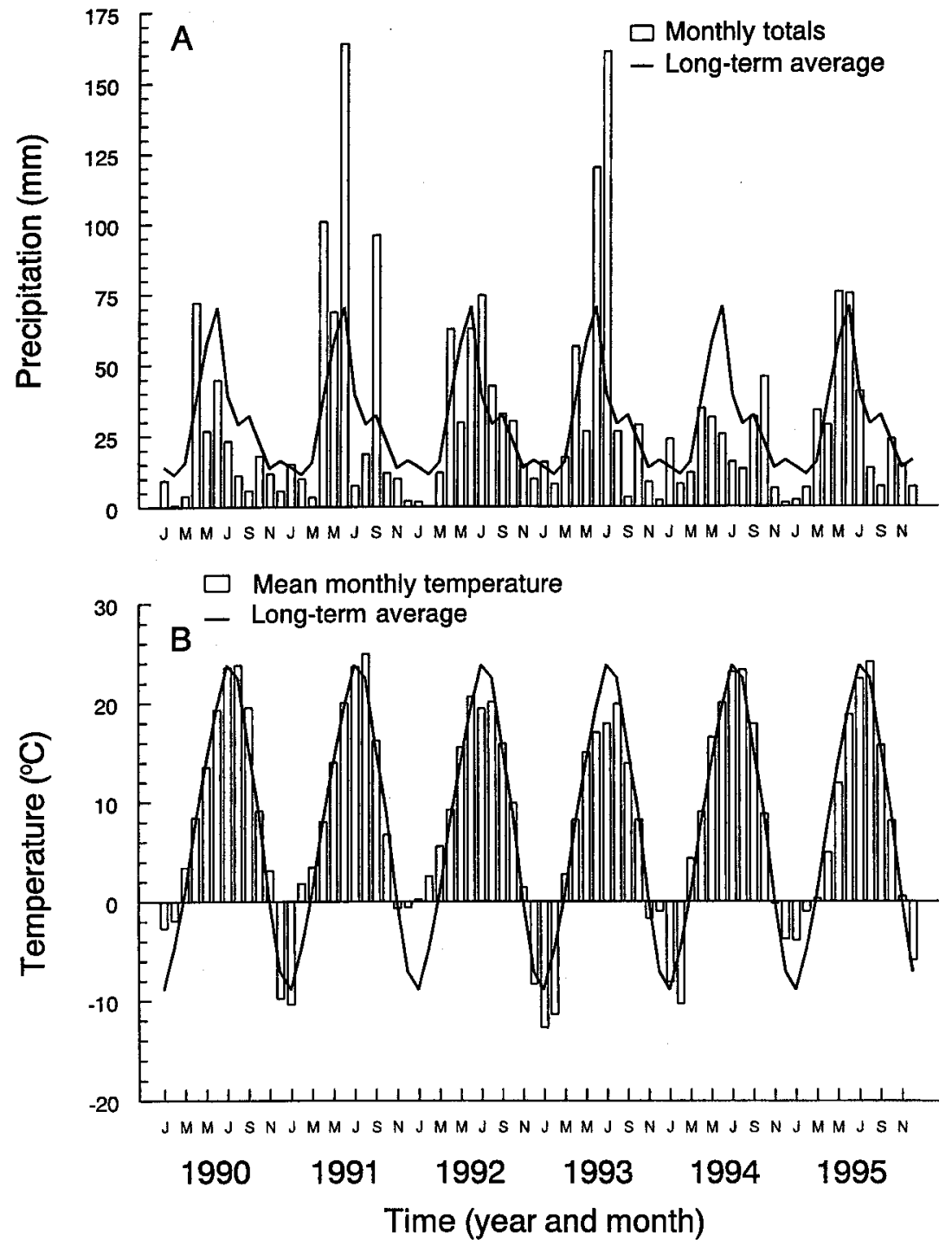

Fig. 1. (A) Precipitation and (B) temperature recorded at the Frank Wiley Airfield (National Oceanic and Atmospheric Administration 1990-1995) located about $11 \mathrm{~km}$ from the study sites for 1990 through 1995.

August. Initial weight of steers averaged $329 \mathrm{~kg}(\mathrm{SD}=31)$ in $1993,273 \mathrm{~kg}(\mathrm{SD}=$ $14)$ in 1994 , and $272 \mathrm{~kg}(\mathrm{SD}=21)$ in 1995. Steers were stratified by initial weight and within strata randomly assigned to pastures. Steers were handled according to protocol approved by the Fort Keogh Livestock and Range Research Laboratory Animal Care and Use Committee.

\section{Field Sampling \\ Pretreatment}

Current-year standing crop was estimated in June 1991 and May 1992 in all pastures just before the beginning of the grazing season by hand harvesting all herbage of the current year above a $25-\mathrm{mm}$ stubble height in fifteen, 30 by $60-\mathrm{cm}$ plots randomly located in each pasture. Herbage was separated by species or species groups, oven dried in a forced draft oven at $60^{\circ} \mathrm{C}$, and weighed. The species groups included Western wheatgrass + Sandberg bluegrass, other perennial grasses [mainly blue grama and buffalo grass (Buchloe dactyloides [Nutt.] Engelm.)], annual grasses [Japanese brome, downy brome, six-weeks fescue (Vulpia octoflora [Walter] Rydb.), and little barley (Hordeum pusillum Nutt.)], sedges, and forbs. These samples were collected during the interim between the current study and earlier experiments reported by Haferkamp et al. (1993). 


\section{Post-treatment}

One key area (50 m by $50 \mathrm{~m}$ ) was centrally located within each pasture prior to the initiation of grazing in 1993. Standing crop was sampled in all pastures by clipping and separating current-year herbage (live plus current-year dead) by plant species or species group. All herbage and previous year standing dead (old dead) as a composite of species were clipped to ground level in 10 randomly located circular $0.25-\mathrm{m}^{2}$ plots in each key area. Throughout the study samples were collected in May, June, July, August, and September, except September in 1994.

Ten, $1-\mathrm{m}$ by $1-\mathrm{m}$ cages were randomly located adjacent to key areas in early May each year. These were used to estimate above ground net primary production (ANPP) in August each year. Current-year (live plus current-year dead) and standing dead were clipped to ground level within a $0.25-\mathrm{m}^{2}$ plot located within each cage. Herbage samples were oven dried in a forced-draft oven at $60^{\circ} \mathrm{C}$ and weighed.

\section{Laboratory Analyses}

Samples were ground to pass through a 1-mm screen in a Wiley mill ${ }^{1}$ (Arthur $\mathrm{H}$. Thomas Co., Philadelphia, Penn.) for total $\mathrm{N}$ and in vitro digestible organic matter (IVDOM) determinations. Total N (organic matter basis) was determined with a Technicon Auto Analyzer (Technicon Industrial Systems 1977) ${ }^{1}$. Data are presented as crude protein (CP; percentage $\mathrm{N} * 6.25)$. In vitro digestible organic matter (IVDOM) was determined using a modified Tilley and Terry (1963) technique (White et al. 1981). Nitrate-N concentration was determined at a commercial laboratory by the ion electrode technique (AOAC 1990) on current year herbage of western wheatgrass collected in May and July each year.

\section{Data Summarization and Analysis Pretreatment}

Similarity of spring standing crop in pastures upon which brome suppression treatments were applied was tested with the residual variation among pastures within treatment for an analysis of variance model for randomly applied treatments with subsamples. Effects of brome suppression treatments on annual net primary production (ANPP) in August 1993,

\footnotetext{
${ }^{1}$ Mention of any trade name or proprietary product does not constitute a guarantee or warranty by the authors or USDA-ARS nor does it imply the approval of these products to the exclusion of others.
}

1994, and 1995, were tested with the residual variation among pastures within treatment. The Least Significant Difference (LSD) method ( $\mathrm{P} \leq 0.05)$ protected by a prior F-test $(\mathrm{P} \leq 0.05)$ was used for comparing treatment means (SAS 1990). All differences discussed are significant at the $\mathrm{P} \leq 0.05$ level unless otherwise noted.

\section{Post-treatment (grazed and ungrazed)}

Analysis of variance was used to test effects of treatments, years, dates, and interactions among them on standing crop. Treatment effects were tested using variation among pastures within treatment as error. Year and treatment by year interaction effects were tested using variability among pastures within year-treatment subclasses. Effects of date and interaction of date with other effects were tested with residual variation after accounting for all other effects in the model.

Comparisons were limited to May, June, July, and August, due to the lack of September samples in 1994. Most statistical analyses of biomass were run by species groups for total current-yearstanding crop (including current dead), total old standing dead, and total standing crop (including current and old standing dead). Percentage CP and IVDOM were statistically analyzed for selected species or groups making up a majority (68 to $94 \%$ ) of the species composition. Individual species included Japanese brome, western wheatgrass, blue grama, forbs, and standing dead. These analyses were run for other species, but as a result of lack of sample material many least square means were not estimable due to missing values.

\section{Results}

\section{Pre-treatment}

Late spring standing crop of all species groups, averaged for 1991 and 1992, were similar ( $\mathrm{P}=0.09$ to 0.91$)$ between pastures subsequently assigned brome suppression treatments (Table 1). Springtime estimates of annual grass biomass in current-year standing crop averaged $525 \mathrm{~kg}$ $\mathrm{ha}^{-1}$ in 1991 and 1992. This was considerably greater than the May standing crops of annual grasses in 1993, 1994, and 1995 (Table 2). The decline in annual grasses clearly shows this study was conducted with below maximum composition of annual grasses.
Table 1. Least-squares means $+\mathrm{SE}$ for ungrazed spring standing crop averaged for 1991 and 1992, the 2 years prior to application of brome suppression treatments. No significant differences were detected between treatments.

\begin{tabular}{lc}
\hline \hline Species group & Standing crop \\
\hline Western wheatgrass & $-\left(\mathrm{kg} \mathrm{ha}^{-1}\right)-$ \\
Sandberg bluegrass & $348 \pm 32$ \\
Forbs & $35 \pm 14$ \\
Other perennial grasses & $36 \pm 8$ \\
Annual grasses & $524 \pm 46$ \\
Sedges & $\mathrm{T} \pm 5$ \\
Total current year & $945 \pm 67$ \\
\hline
\end{tabular}

\section{Herbage Standing Crop}

Samples collected during the growing season reflected not only brome suppression but also the influences of precipitation, temperature, and grazing by cattle. The forage base varied temporally among dates and years (Table 2), but generally was not less than $800 \mathrm{~kg} \mathrm{ha}^{-1}$.

Annual grasses were reduced by brome suppression on each sample date in 1993 and 1995, but not in 1994 (Table 2). Total current-year standing crop and total standing crop were reduced by brome suppression in June and July 1993, August 1994, and July 1995.

Standing crop varied among dates within years (Table 2). The relatively large total standing crop in May 1994 resulted from the large amount of standing dead carried over from the relatively wet summer of 1993. Other perennial grasses were most prominent $(\mathrm{P}<0.01)$ in the July sample $\left(330 \mathrm{~kg} \mathrm{ha}^{-1}\right)$ and least prominent in May $\left(110 \mathrm{~kg} \mathrm{ha}^{-1}\right)$, whereas forbs decreased $(\mathrm{P} \leq$ 0.01 ) from a high in May and June of $85 \mathrm{~kg}$ $\mathrm{ha}^{-1}$ to $20 \mathrm{~kg} \mathrm{ha}^{-1}$ in August. Western wheatgrass + Sandberg bluegrass increased $(\mathrm{P} \leq$ 0.01 ) during 1993 and peaked in June and July 1995.

\section{Aboveground Net Primary Production From Cages}

Annual grass was the only component of ANPP affected by brome suppression. Brome suppression reduced $(\mathrm{P}<0.01)$ ANPP of annual grasses in 1993 (410 vs. $\left.25 \pm 42 \mathrm{~kg} \mathrm{ha}^{-1}\right)$, but not $1994(25 \pm 42 \mathrm{~kg}$ $\left.\mathrm{h}^{-1}\right)$ or $1995\left(168 \pm 42 \mathrm{~kg} \mathrm{ha}^{-1}\right)$. Above ground net primary production of western wheatgrass + Sandberg bluegrass $(1,405$ vs. $\left.820 \pm 140 \mathrm{~kg} \mathrm{ha}^{-1} ; \mathrm{P} \leq 0.05\right)$, forbs (180 vs. $\left.35 \pm 34 \mathrm{~kg} \mathrm{ha}^{-1} ; \mathrm{P} \leq 0.03\right)$, and total biomass $(2,213$ vs. $1,525 \pm 167 \mathrm{~kg}$ $\left.\mathrm{ha}^{-1} ; \mathrm{P} \leq 0.01\right)$ were also highest in 1993 . Amount of dead material was greatest $(\mathrm{P} \leq$ $0.03)$ in $1994\left(409 \pm 57 \mathrm{~kg} \mathrm{ha}^{-1}\right)$ and smallest in $1993\left(109 \pm 56 \mathrm{~kg} \mathrm{ha}^{-1}\right)$. 
Table 2. Least-squares means \pm SE for significant year by date by brome suppression treatment interaction for standing crop from grazed pastures. Comparisons are only made between brome suppression treatments and among dates within each year.

Year

Component

Brome treatment

May
Date

\section{3}

Annual grass

Date
June

July

August

SE

Undisturbed

Suppressed

Current year ${ }^{2}$

Undisturbed

Suppressed

Total $^{2}$

Undisturbed

Suppressed

1994

Annual grass

Undisturbed

Suppressed

Current year $^{2}$

Undisturbed

Suppressed

Total $^{2}$

Undisturbed

Suppressed

1995

Annual grass

Undisturbed

Suppressed

Current year ${ }^{2}$

Undisturbed

Suppressed

Total $^{2}$

Undisturbed

Suppressed

$141^{\mathrm{Da} 1}$
$13^{\mathrm{Ab}}$
$681^{\mathrm{Ca}}$
$470^{\mathrm{Ca}}$
$906^{\mathrm{Ca}}$
$726^{\mathrm{Ca}}$

$426^{\mathrm{Aa}}$
$12^{\mathrm{Ab}}$

$$
386^{\mathrm{Ba}}
$$$$
29^{\mathrm{Ab}}
$$$$
246^{\mathrm{Ca}}
$$$$
1,318^{\mathrm{Ba}}
$$$$
867^{\mathrm{Bb}}
$$

$1,660^{\mathrm{Aa}}$

$1,284^{\mathrm{Ab}}$

$$
1,556^{\mathrm{ABa}}
$$$$
1,480^{\mathrm{Aa}}
$$$$
1,534^{\mathrm{Ba}}
$$$$
1,080^{\mathrm{Bb}}
$$$$
1,893^{\mathrm{Aa}}
$$$$
1,409^{\mathrm{ABb}}
$$$$
1,684^{\mathrm{Ba}}
$$$$
1,580^{\mathrm{Aa}}
$$

$30^{\mathrm{Aa}}$
$4^{\mathrm{Aa}}$

$$
88^{\text {Aa }}
$$$$
49^{\mathrm{Aa}}
$$$$
42^{\mathrm{Aa}}
$$$$
4^{\mathrm{Aa}}
$$$$
19^{\mathrm{Aa}}
$$$$
2^{\mathrm{Aa}}
$$$$
778^{\mathrm{Ca}} \quad 1,203^{\mathrm{Aa}}
$$$$
905^{\mathrm{Aa}}
$$$$
1,001^{\mathrm{Aa}}
$$$$
1,081^{\mathrm{ABa}}
$$$$
1,100^{\mathrm{Aa}}
$$$$
897^{\mathrm{BCa}}
$$$$
609^{\mathrm{Bb}}
$$$$
1,737^{\mathrm{Aa}}
$$$$
1,798^{\mathrm{Aa}}
$$$$
1,660^{\mathrm{Aa}}
$$$$
1,572^{\mathrm{ABa}}
$$$$
1,758^{\mathrm{Aa}}
$$$$
1,372^{\mathrm{Ba}}
$$$$
950^{\mathrm{Bb}}
$$

, $745^{\mathrm{A}}$

$$
\begin{array}{r}
131^{\mathrm{Ca}} \\
27^{\mathrm{Bb}} \\
829^{\mathrm{Ca}} \\
821^{\mathrm{Ca}} \\
1,461^{\mathrm{Ca}} \\
1,210^{\mathrm{Ba}}
\end{array}
$$$$
310^{\mathrm{Ba}}
$$$$
140^{\mathrm{Ab}}
$$$$
432^{\mathrm{Aa}}
$$$$
102^{\mathrm{ABb}}
$$$$
184^{\mathrm{Ca}}
$$$$
69^{\mathrm{ABb}}
$$$$
1,440^{\mathrm{Ba}}
$$$$
1,423^{\mathrm{Aa}}
$$$$
1,756^{\mathrm{Aa}}
$$$$
1,437 \mathrm{Ab}
$$$$
967^{\mathrm{Ca}}
$$$$
1,077^{\mathrm{Ba}}
$$

$1,891^{\mathrm{Ba}}$

$1,703^{\mathrm{Aa}}$

$2,326^{\mathrm{Aa}}$

$1,786^{\mathrm{Ab}}$

$1,309^{\mathrm{Ca}}$

$1,322^{\mathrm{Ba}}$

${ }^{1}$ Comparison of date effect for each brome suppression treatment (within a row) is indicated by uppercase superscript. Comparison of brome suppression treatment effect for each component and year (within a column) is indicated by lower case superscript. Means with similar superscripts are not significantly different $(\mathrm{P} \leq 0.05)$.

${ }^{2}$ Current year refers to plant material grown during the current year and total includes both current year plant material and residual plant material from previous years.

\section{Forage Nutritional Quality \\ Ungrazed from Cages}

Brome suppression usually increased the forage nutritional quality of western wheatgrass, Japanese brome, and standing dead (Table 3) in 1993 and 1994, years immediately after brome suppression. The findings suggest Japanese brome plants escaping suppression exhibited higher quality than undisturbed brome plants. Digestibility of standing dead decreased slightly $(\mathrm{P} \leq 0.05)$ from $47.2 \%$ to $43 \%$ with brome suppression, but IVDOM of other species groups was not affected (Table 3).

\section{Grazed}

Crude protein: Response to brome suppression varied with year and date. Averaged across dates, brome suppression increased CP in western wheatgrass in 1993 and 1994, but not 1995 (Table 5). affected by brome suppression $(\mathrm{P}=0.21$; data not shown). While the concentration declined significantly $(\mathrm{P} \leq 0.05)$ from $0.043 \%$ in May to 0.016 in July 1993, values did not differ among dates in 1994 or 1995.

IVDOM: Digestibility of standing dead decreased $(\mathrm{P} \leq 0.01)$ with advancing date with both treatments in 1993 but not in 1994 or 1995. Digestibility tended to increase with advancing date when brome was suppressed in 1994. Digestibility varied among dates within years in western wheatgrass $(\mathrm{P}$ $\leq 0.01)$, blue grama $(\mathrm{P} \leq 0.05)$, and forbs ( $\mathrm{P} \leq$ 0.01; Fig. 2). Obtaining a good estimate of trends in IVDOM of Japanese brome was difficult due to lack of sufficient material for sampling.

\section{Discussion}

Abundance of brome is dependent upon the seedbank (Karl et al. 1999), temperature, and amount and distribution of precipitation (Haferkamp et al. 1993, Whisenant 1990). Suppression of brome requires reduction of annual brome seedbank through environmental and/or managerial (burning, herbicide, hand removal, grazing) means. Suppression of annual bromes is a continuing challenge. Adequate residual seed may be available even after 2 years of suppression to allow an increase in brome abundance, as occurred in 1995 of this study.

Amount and distribution of autumn precipitation are critical for seedling emergence, and spring and summer precipitation are critical for seedling and plant growth. Unusual events such as the prolonged period of precipitation in $1993 \mathrm{kept}$ plants growing later into the grazing season than usually occurs. Haferkamp et al. (1993) reported that the most important factors affecting annual brome production in spring 1983 through spring 1990 were monthly precipitation in October, January, and April; 2-month precipitation totals in March and April and average temperature in January and February; and 3-month precipitation totals in March to May and average temperatures in March and May and September through November. Brome is often abundant when autumn precipitation is high, spring precipitation is high after a dry fall and winter, and distribution is adequately uniform to allow the soil to remain wet for 3 to 5 days. A dry autumn (1993) and spring (1994) reduced brome abundance in 1994. Autumn precipitation in $1992(77 \mathrm{~mm})$ and $1994(83 \mathrm{~mm})$ was 12 and $20 \%$, respectively, above the long- 
Table 3. Least-squares means $\pm \mathrm{SE}$ of percentage $\mathrm{CP}$ concentration for the year by brome suppression treatment interaction for western wheatgrass and Japanese brome and for years averaged across treatments for blue grama. Least-square means of percentage IVDOM concentration for years averaged across treatments for western wheatgrass, Japanese brome, and standing dead, for samples harvested from cages in August each year.

\begin{tabular}{|c|c|c|c|c|}
\hline \multirow{2}{*}{$\begin{array}{l}\text { Component } \\
\text { Brome treatment }\end{array}$} & \multicolumn{4}{|c|}{ Year } \\
\hline & 1993 & 1994 & 1995 & $\mathrm{SE}$ \\
\hline $\begin{array}{l}\text { Western wheatgrass } \\
\text { Undisturbed } \\
\text { Suppressed }\end{array}$ & $\begin{array}{c}7.8^{\mathrm{Ab} 1} \\
10.8^{\mathrm{Aa}}\end{array}$ & $\begin{array}{l}3.4^{\mathrm{Cb}} \\
5.2^{\mathrm{Ba}}\end{array}$ & $\begin{array}{l}5.7^{\mathrm{Ba}} \\
5.2^{\mathrm{Ba}}\end{array}$ & 0.36 \\
\hline $\begin{array}{l}\text { Japanese brome } \\
\text { Undisturbed } \\
\text { Suppressed }\end{array}$ & $\begin{array}{r}4.1 \pm 0.71^{\mathrm{Ab}} \\
10.9 \pm 1.00^{\mathrm{Aa}}\end{array}$ & $\begin{array}{l}3.2 \pm 0.71^{\mathrm{Aa}} \\
6.1 \pm 1.00^{\mathrm{Ba}}\end{array}$ & $\begin{array}{l}4.0 \pm 0.71^{\mathrm{Aa}} \\
3.6 \pm 0.71^{\mathrm{Ba}}\end{array}$ & \\
\hline Blue grama & $10.4^{\mathrm{A}}$ & $4.5^{\mathrm{C}}$ & $7.6^{\mathrm{B}}$ & 0.35 \\
\hline $\begin{array}{l}\text { Standing dead } \\
\text { Undisturbed } \\
\text { Suppressed }\end{array}$ & $\begin{array}{l}5.1^{\mathrm{ABb}} \\
7.0^{\mathrm{Aa}}\end{array}$ & $\begin{array}{l}3.9^{\mathrm{Bb}} \\
5.4^{\mathrm{Ba}}\end{array}$ & $\begin{array}{l}6.1^{\mathrm{Aa}} \\
5.3^{\mathrm{Ba}}\end{array}$ & 0.46 \\
\hline $\begin{array}{l}\text { Western wheatgrass } \\
\text { Japanese brome }\end{array}$ & $\begin{array}{l}54.5^{\mathrm{C}} \\
38.7 \pm 1.86^{\mathrm{B}}\end{array}$ & $\begin{array}{l}60.5^{\mathrm{A}} \\
50.0 \pm 1.41^{\mathrm{A}}\end{array}$ & $\begin{array}{l}56.5^{\mathrm{B}} \\
42.8 \pm 1.48^{\mathrm{B}}\end{array}$ & 0.60 \\
\hline Standing dead & $38.7^{\mathrm{C}}$ & $49.3^{\mathrm{A}}$ & $47.3^{\mathrm{B}}$ & 0.55 \\
\hline
\end{tabular}

${ }^{1}$ Comparison of year effect for each species group or brome suppression treatment (within a row) is indicated by uppercase superscripts. Comparison of brome suppression treatment effect on western wheatgrass, Japanese brome, and standing dead for each year (within a column) is indicated by lower case superscripts. Means with similar superscripts are not significantly different $(\mathrm{P} \leq 0.05)$.

term 69-mm average, and abundance of brome was relatively high in 1993 and 1995. A wet spring in 1991 after a dry autumn and winter in 1990 was adequate to provide a productive annual brome year.

Growing-season precipitation influences size and nutritional quality of standing crop and amount of standing dead remaining in pastures. Cool temperatures and above average precipitation in March, April, June, and July 1993 (Fig. 1), produced more forage than steers could consume. Thus, standing crop increased through the summer, and forage quality remained relatively high. Increased growth in 1993 provided large amounts of biomass that were measured as standing dead throughout 1994. This large amount of current-dead biomass may have prevented spray from reaching the soil surface and reduced the effectiveness of atrazine applied in November 1993. Below average precipitation in March and May through August 1994 reduced standing crop, and forced us to remove steers from pastures early in August 1994. Near average precipitation in 1995 produced standing crops similar to 1993 except in August.

We used the $0.5 \mathrm{~kg}$ a.i. ha ${ }^{-1}$ rate of atrazine to reduce suppression of perennial grasses and sedges encountered in other studies with higher rates of application (Hart et al. 1995, Currie et al. 1987, Hewlett et al. 1981, Houston 1977) and to reduce the increase in $\mathrm{N}$ concentration often found in plants treated with sublethal doses of triazine herbicides (Miller and ply reflect the difference in degree of brome suppression. Hand pulling seedlings provides a higher degree of brome suppression than chemical treatment. However, these other studies did not contain any data from years with as little precipitation as 1994. Annual bromes simply do not establish or grow well during dry growing seasons.

The increase in forage $\mathrm{CP}$ of western wheatgrass with brome suppression agrees with other findings at this location (Haferkamp and others 1998, file data). We found a slight but significant increase in CP concentration of western wheatgrass ( 8.3 to $9.0 \%$ ) with hand removal of brome seedlings before 15 May 1995. In contrast, Currie et al. (1987) found only slight nonsignificant differences in CP concentration in herbage sampled in early July from a blue grama-western wheatgrass dominated plant community sprayed 1 to 2 years earlier with atrazine at $0.6 \mathrm{~kg}$ a.i. $\mathrm{ha}^{-1}$. This increase in quality may result as brome suppression reduces use of soil water and allows perennial forages to continue growing later into the grazing season. Brome suppression also creates a forage base with less senesced brome and more actively growing green perennial plants than occurs on adjacent pastures with brome present.

Crude protein concentrations may have also been increased, particularly in 1993, by the effect of sublethal doses of atrazine on indigenous perennial species. The effect of suppression of competition has not been totally differentiated from the enhancement by the sublethal dose. This is in part due to the similarity of responses resulting from suppression of competition or from sublethal doses of triazine herbicides. In a few cases where perennial coolseason grasses were grown without competition, applications of simazine [2chloro-4,6 bis (ethylamino)-s-triazine] Haferkamp et al 1997, 1998). The lack of agreement among these studies may sim-

Table 4. Least-squares means $\pm \mathrm{SE}$ for percentage $\mathrm{CP}$ concentration for significant year by brome suppression treatment interactions in grazed samples.

\begin{tabular}{|c|c|c|c|}
\hline \multirow{2}{*}{$\begin{array}{l}\text { Species group } \\
\text { Brome treatment }\end{array}$} & \multicolumn{3}{|c|}{ Year } \\
\hline & 1993 & 1994 & 1995 \\
\hline \multicolumn{4}{|l|}{ Western wheatgrass } \\
\hline Undisturbed & $10.7 \pm 0.41^{\mathrm{Ab} 1}$ & $9.5 \pm 0.41^{\mathrm{Ab}}$ & $9.7 \pm 0.41^{\mathrm{Aa}}$ \\
\hline Suppressed & $14.8 \pm 0.41^{\mathrm{Aa}}$ & $11.4 \pm 0.41^{\mathrm{Ba}}$ & $10.5 \pm 0.41^{\mathrm{Ba}}$ \\
\hline \multicolumn{4}{|l|}{ Japanese brome } \\
\hline Undisturbed & $8.2 \pm 0.39^{\mathrm{Ab}}$ & $9.0 \pm 0.39^{A}$ & $8.2 \pm 0.39^{\mathrm{Ab}}$ \\
\hline Suppressed & $13.9 \pm 0.44^{\mathrm{Aa}}$ & - & $10.3 \pm 0.39^{\mathrm{Ba}}$ \\
\hline \multicolumn{4}{|l|}{ Forbs } \\
\hline Undisturbed & $16.7 \pm 0.60^{\mathrm{Ab}}$ & $11.4 \pm 0.60^{\mathrm{Bb}}$ & $11.6 \pm 0.60^{\mathrm{Ba}}$ \\
\hline Suppressed & $21.8 \pm 0.60^{\mathrm{Aa}}$ & $13.9 \pm 0.85^{\mathrm{Ba}}$ & $12.4 \pm 0.60^{\mathrm{Ba}}$ \\
\hline
\end{tabular}

${ }^{1}$ Comparison of year effect for each brome suppression treatment (within a row) is indicated by uppercase superscripts. Comparison of brome suppression treatment effect for each year (within a column) is indicated by lower case superscripts. Means with similar superscripts are not significantly different $(\mathrm{P} \leq 0.05)$. 

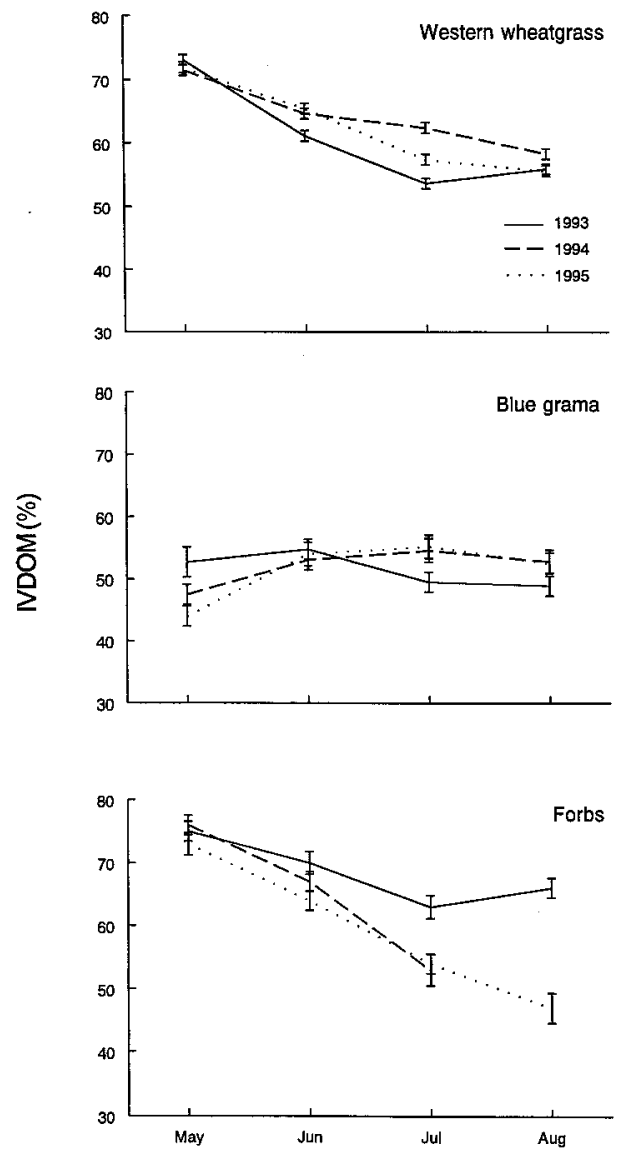

Fig. 2. Least squares means \pm standard errors for percentage IVDOM concentration of significant date by year interactions for western wheatgrass, blue grama, and forbs.
Table 5. Least-squares means $\pm \mathrm{SE}$ for percentage $\mathrm{CP}$ concentration for significant brome suppression treatment by date and year by date interactions in grazed samples.

\begin{tabular}{|c|c|c|c|c|}
\hline \multirow{2}{*}{$\begin{array}{l}\text { Component } \\
\text { Brome treatment/year }\end{array}$} & \multirow[b]{2}{*}{ May } & \multicolumn{2}{|r|}{ Date } & \multirow[b]{2}{*}{ August } \\
\hline & & June & July & \\
\hline $\begin{array}{l}\text { Western wheatgrass } \\
\text { Undisturbed } \\
\text { Suppressed }\end{array}$ & $\begin{array}{l}15.4 \pm 0.35^{\mathrm{Ab} 1} \\
19.4 \pm 0.35^{\mathrm{Aa}}\end{array}$ & $\begin{array}{l}11.4 \pm 0.35^{\mathrm{Bb}} \\
13.3 \pm 0.35^{\mathrm{Ba}}\end{array}$ & $\begin{array}{l}7.1 \pm 0.35^{\mathrm{Cb}} \\
9.1 \pm 0.35^{\mathrm{Ca}}\end{array}$ & $\begin{array}{l}6.0 \pm 0.35^{\mathrm{Db}} \\
7.1 \pm 0.35^{\mathrm{Da}}\end{array}$ \\
\hline $\begin{array}{l}\text { Japanese brome } \\
\text { Undisturbed } \\
\text { Suppressed }\end{array}$ & $\begin{array}{l}15.0 \pm 0.60^{\mathrm{Ab}} \\
\text { non. est. }^{2}\end{array}$ & $\begin{array}{l}9.7 \pm 0.60^{\mathrm{Ba}} \\
\text { non. est. }\end{array}$ & $\begin{array}{l}4.9 \pm 0.60^{\mathrm{Cb}} \\
\text { non. est. }\end{array}$ & $\begin{array}{l}4.2 \pm 0.60^{\mathrm{C}} \\
\text { non. est. }\end{array}$ \\
\hline $\begin{array}{l}\text { Forbs } \\
\text { Undisturbed } \\
\text { Suppressed }\end{array}$ & $\begin{array}{l}16.7 \pm 0.63^{\mathrm{Ab}} \\
20.3 \pm 0.63^{\mathrm{Aa}}\end{array}$ & $\begin{array}{l}14.3 \pm 0.63^{\mathrm{Bb}} \\
16.4 \pm 0.63^{\mathrm{Ba}}\end{array}$ & $\begin{array}{l}11.7 \pm 0.63^{\mathrm{Ca}} \\
11.9 \pm 0.71^{\mathrm{Ca}}\end{array}$ & $\begin{array}{l}10.3 \pm 0.63^{\mathrm{Cb}} \\
15.7 \pm 0.87^{\mathrm{Ba}}\end{array}$ \\
\hline $\begin{array}{l}\text { Western wheatgrass } \\
1993 \\
1994 \\
1995\end{array}$ & $\begin{array}{l}18.7 \pm 0.43^{\mathrm{Aa}} \\
16.9 \pm 0.43^{\mathrm{Ab}} \\
16.6 \pm 0.43^{\mathrm{Ab}}\end{array}$ & $\begin{array}{l}12.5 \pm 0.43^{\mathrm{Ba}} \\
12.4 \pm 0.43^{\mathrm{Ba}} \\
12.1 \pm 0.43^{\mathrm{Ba}}\end{array}$ & $\begin{array}{r}10.0 \pm 0.43^{\mathrm{Ca}} \\
8.0 \pm 0.43^{\mathrm{Cb}} \\
6.3 \pm 0.43^{\mathrm{Cc}}\end{array}$ & $\begin{array}{l}9.9 \pm 0.43^{\mathrm{Ca}} \\
4.4 \pm 0.43^{\mathrm{Db}} \\
5.4 \pm 0.50^{\mathrm{Cb}}\end{array}$ \\
\hline $\begin{array}{l}\text { Japanese brome } \\
1993 \\
1994 \\
1995\end{array}$ & $\begin{array}{l}18.4 \pm 0.73^{\mathrm{Aa}} \\
\text { non. est. } \\
17.0 \pm 0.73^{\mathrm{Aa}}\end{array}$ & $\begin{array}{l}9.9 \pm 0.85^{\mathrm{Ba}} \\
\text { non. est. } \\
11.5 \pm 0.73^{\mathrm{Ba}}\end{array}$ & $\begin{array}{l}8.4 \pm 0.73^{\mathrm{Ba}} \\
\text { non. est. } \\
4.7 \pm 0.73^{\mathrm{Cb}}\end{array}$ & $\begin{array}{l}7.6 \pm 0.85^{\mathrm{Ba}} \\
\text { non. est. } \\
3.7 \pm 0.73^{\mathrm{Cb}}\end{array}$ \\
\hline $\begin{array}{l}\text { Blue grama } \\
1993 \\
1994 \\
1995\end{array}$ & $\begin{array}{r}11.2 \pm 0.49^{\mathrm{Aa}} \\
9.8 \pm 0.49^{\mathrm{Aa}} \\
10.4 \pm 0.57^{\mathrm{Aa}}\end{array}$ & $\begin{array}{c}10.0 \pm 0.49^{\mathrm{ABa}} \\
9.6 \pm 0.49^{\mathrm{Aa}} \\
10.8 \pm 0.57^{\mathrm{Aa}}\end{array}$ & $\begin{array}{l}9.1 \pm 0.49^{\mathrm{Ba}} \\
6.9 \pm 0.58^{\mathrm{Bb}} \\
6.8 \pm 0.57^{\mathrm{Bb}}\end{array}$ & $\begin{array}{l}9.5 \pm 0.49^{\mathrm{Ba}} \\
4.9 \pm 0.58^{\mathrm{Cc}} \\
6.8 \pm 0.49^{\mathrm{Bb}}\end{array}$ \\
\hline $\begin{array}{l}\text { Forbs } \\
1993 \\
1994 \\
1995\end{array}$ & $\begin{array}{l}20.3 \pm 0.77^{\mathrm{Aa}} \\
18.0 \pm 0.77^{\mathrm{Ab}} \\
17.2 \pm 0.77^{\mathrm{Ab}}\end{array}$ & $\begin{array}{l}17.9 \pm 0.77^{\mathrm{Ba}} \\
14.2 \pm 0.77^{\mathrm{Bb}} \\
13.8 \pm 0.77^{\mathrm{Bb}}\end{array}$ & $\begin{array}{r}16.8 \pm 0.77^{\mathrm{Ba}} \\
8.4 \pm 0.91^{\mathrm{Cb}} \\
10.2 \pm 0.77^{\mathrm{Cb}}\end{array}$ & $\begin{array}{r}22.1 \pm 0.77^{\mathrm{Aa}} \\
9.9 \pm 1.19^{\mathrm{Cb}} \\
7.0 \pm 0.77^{\mathrm{Dc}}\end{array}$ \\
\hline $\begin{array}{l}\text { Standing dead } \\
1993 \\
1994 \\
1995\end{array}$ & $\begin{array}{l}4.3 \pm 0.35^{\mathrm{Bb}} \\
6.9 \pm 0.35^{\mathrm{Aa}} \\
6.5 \pm 0.35^{\mathrm{Aa}}\end{array}$ & $\begin{array}{l}5.2 \pm 0.35^{\mathrm{ABb}} \\
7.4 \pm 0.35^{\mathrm{Aa}} \\
5.4 \pm 0.35^{\mathrm{Bb}}\end{array}$ & $\begin{array}{l}5.3 \pm 0.35^{\mathrm{Ab}} \\
6.5 \pm 0.35^{\mathrm{Aa}} \\
5.0 \pm 0.35^{\mathrm{Bb}}\end{array}$ & $\begin{array}{l}5.1 \pm 0.35^{\mathrm{ABab}} \\
4.4 \pm 0.35^{\mathrm{Bb}} \\
5.7 \pm 0.35^{\mathrm{ABa}}\end{array}$ \\
\hline
\end{tabular}

${ }^{1}$ Comparison of date effect for each brome suppression treatment or year (within a row) is indicated by upper case superscripts. Comparison of brome suppression treatments or years for each date (within a column) is indicated by lower case superscripts. Means with similar superscripts are not significantly different $(\mathrm{P} \leq 0.05)$.

${ }^{2}$ Non-est. = years with non-estimable least-square-means due to lack of available sample for chemical analysis. increased CP concentrations from $10.0 \%$ to $12.2 \%$ (Allison and Peters 1970). Nitrogen concentrations increased from $1.49 \%$ to $2.33 \%$ in blue grama leaves treated with atrazine (Morgan and Knight 1991).

Miller and Doxtader (1995) cautioned that apparent increases in $\mathrm{CP}$ concentration may only be increases in mineral $\mathrm{N}$ concentration. This was not so in the western wheatgrass samples from our study, because $\mathrm{NO}_{3}-\mathrm{N}$ concentrations were very low, less than $0.05 \%$, and did not differ between treated and untreated pastures. The low values are a reflection of $\mathrm{N}$ and water being the major factors limiting plant growth on Northern Great Plains rangelands (Halvorson and White 1981). The limiting effect of soil $\mathrm{N}$ has been demonstrated many times by the increase in forage production with the addition of $\mathrm{N}$ from chemical fertilizer (White 1985, Wight 1976, Lorenz and Rogler 1972).

Similar to our findings, others have found the largest differences between tri- azine treated and untreated plants occur during the spring after treatment the previous autumn, and the differences become progressively smaller during summer and following years (Houston and van der Sluijs 1975). Rhem (1984), however, found no increase in CP concentration of perennial, warm-season grasses with atrazine application when plants were harvested in early to mid-August.

Brome suppression definitely increased forage quality of western wheatgrass, a dominant perennial cool-season grass on Northern Great Plains ranges. Gains of steers were also increased $16 \%$ by suppression of annual bromes (Haferkamp et al. 2001). However, impact of brome suppression on livestock depends on the amount of annual brome infestation, the uniformity of annual brome infestation, and amount of annual brome consumed by grazing livestock. Standing crop of annual grasses was relatively small in 1993 through 1995, when compared to 1989 and 1990 (Haferkamp et al. 1993), 1991, and communities studied by other researchers (Heitschmidt et al. 1995, Whisenant 1990, Currie et al. 1987). However, the untreated pastures in our study were uniformly infested by annual bromes. With these conditions, livestock gains may be impacted more than in studies where animals grazed pastures with spotty distributions of annual brome that allowed greater selection of other herbage by the grazing animal.

\section{Literature Cited}

Allison, D.W. and R.A. Peters. 1970. Influence of simazine on crude protein and cellulose content and yield of forage grasses. Agron. J. 62:246-250.

AOAC. 1990. Official methods of analysis. Assoc. Off. Anal. Chem. 15 ${ }^{\text {th }}$ Ed. Washington, DC.

Cline, J.F. and E.F. Rickard. 1993. Herbage yields in relation to soil water and assimilated nitrogen. J. Range Manage. 26:296-298.

Currie, P.O., J.D. Volesky, T.O. Hilken, and R.S. White. 1987. Selective control of annual bromes in perennial grass stands. J. Range Manage. 40:547-550. 
Fleming, C.E., M.A. Shipley, and M.R. Miller. 1942. Broncograss (Bromus tectorum) on Nevada ranges. Nev. Agr. Exp. Sta. Bull. 159. Reno, Nev.

Gartner, F.R., E.M. White, and R.I Butterfield. 1986. Mechanical treatment and burning for high quality range forage, p.135140. In: South Dakota Beef Report, Animal Range Sciences Dept., Agr. Exp. Sta., Coop. Ext. Serv., South Dakota State Univ., Brookings, S. Dak.

Haferkamp, M.R. and R.K. Heitschmidt. 1999. Japanese brome impacts on western wheatgrass in Northern Great Plains rangelands: An update. Great Plains Research 9:315-327.

Haferkamp, M.R., R.K. Heitschmidt, and M.G. Karl. 1997. Influence of Japanese brome on western wheatgrass yield. J. Range Manage. 50:44-50.

Haferkamp, M.R., R.K. Heitschmidt, and M.G. Karl. 1998. Clipping and Japanese brome reduce western wheatgrass standing crop. J. Range Manage. 51:692-698.

Haferkamp, M.R., E.E. Grings, R.K. Heitschmidt, M.D. MacNeil, and M.G. Karl. 2001. Suppression of annual brome impacts rangeland: Animal responses. J. Range Manage. 54:663-668.

Haferkamp, M.R., J.D. Volesky, M.M. Borman, R.K. Heitschmidt, and P.O. Currie. 1993. Effects of mechanical treatments and climatic factors on the productivity of Northern Great Plains rangelands. J. Range Manage. 46:346-350.

Haferkamp, M.R., J.A. Young, E.E. Grings, M.G. Karl, R.K. Heitschmidt, and M.D MacNeil. 1994. Japanese brome in the Northern Great Plains, p.396-401. In: S.B. Monsen and S.G. Kitchen (eds.) Proc.-Ecology and management of annual rangelands. 18-21 May 1992. Boise, Ida., USDA-FS Gen. Tech. Rep. INTGTR 313. Ogden, Ut.

Halvorson, A.D. and L.M. White. 1981. Nitrogen fertilization effects on seasonal $\mathrm{Ca}$, $\mathrm{Mg}, \mathrm{P}$, and $\mathrm{K}$ levels of western wheatgrass and green needlegrass. Agron. J. 73:651-656.

Hart, R.H., M.C. Shoop, and M.M. Ashby. 1995. Nitrogen and atrazine on shortgrass: Vegetation, cattle and economic responses. J. Range Manage. 48:165-171.
Heitschmidt, R.K., E.E. Grings, M.R. Haferkamp, and M.G. Karl. 1995. Herbage dynamics on 2 Northern Great Plains range sites. J. Range Manage. 48:211-217.

Hewlett, D.B., J.R. Johnson, R.I. Butterfield, and V.K. Mosley. 1981. Japanese brome response to atrazine in combination with nitrogen fertilizer in the mixed prairie. J. Range Manage. 34:22-25.

Houston, W.R. 1977. Species susceptibility to atrazine herbicide on shortgrass range. J. Range Manage. 30:50-52.

Houston, W.R. and D.H. van der Sluijs. 1975. S-triazine herbicides combined with nitrogen fertilizer for increasing protein on shortgrass range. J. Range Manage. 28:372-376.

Karl, M.G., R.K. Heitschmidt, and M.R. Haferkamp. 1999. Vegetation biomass dynamics and patterns of sexual reproduction in northern mixed-grass prairie. Amer. Midl. Nat. 141:227-237.

Kay, B.L. 1971. Atrazine and simazine increase yield and quality of range forage. Weed Sci. 19:370-372.

Kuchler, A.W. 1964. Potential natural vegetation of the conterminous United States. Amer. Geog. Soc. Spec. Pub. 36. Amer. Geog. Soc. New York, N.Y.

Lorenz, R.J. and G.A. Rogler. 1972. Forage production and botanical composition of mixed prairie as influenced by nitrogen and phosphorus fertilization. Agron. J. 64:244-249.

Mayland, H.F., R.B. Murray, and G.E. Shewmaker. 1994. Forage yields and quality trends of annual grasses in the Great Basin, p. 387-391. In: S.B. Monsen and S.G. Kitchen (eds.) Proc.-Ecology and management of annual rangelands. 18-21 May 1992. Boise, Ida., USDA-FS Gen. Tech. Rep. INT-GTR 313. Ogden, Ut.

McLendon, T. and E.F. Redente. 1994. Role of nitrogen availability in the transition from annual-dominated to perennial dominated seral communities, p. 352-362. In: S.B. Monsen and S.G. Kitchen (eds.) Proc.-Ecology and management of annual rangelands. 18-21 May 1992. Boise, Ida., USDA-FS Gen. Tech. Rep. INT-GTR 313. Ogden, Ut.

Miller, M.S. and K.G. Doxtader. 1995. Atrazine impacts on shortgrass prairie microcosms. J. Range Manage. 48:298-306.
Morgan, J.A. and W.G. Knight. 1991. Growth and physiological responses of greenhousegrown blue grama to atrazine. Agron. J. 83:677-683.

Mosley, J.C. 1996. Prescribed sheep grazing to suppress cheatgrass: A review. Sheep and Goat Res. J. 12:74-81.

National Oceanic and Atmospheric Administration. 1990-1995. Climatological data annual summary, Montana. 93-98:13.

Rehm, G.W. 1984. Yield and quality of a warmseason grass mixture treated with $\mathrm{N}, \mathrm{P}$, and atrazine. Agron. J. 76:731-734.

Rummell, R.S. 1946. Some effects of competition from cheatgrass brome on crested wheatgrass and bluestem wheatgrass. Ecol. 27:159-167.

SAS. 1990. SAS/STAT user's guide. Vol. 2, Version 6 (4th Ed.). SAS Inst. Inc. Cary, N.C.

Technicon Industrial Systems. 1977. Digestion and sample preparation for the analysis of total Kjeldahl nitrogen/phosphorus using the Technicon BD-20 block digester. Technicon Autoanalyzer II Methodology. Industrial Method No. 369-75 A/B. Technicon Industrial Systems. Tarrytown, N.Y.

Tilley, J.M.A. and R.A. Terry. 1963. A twostage technique for the in vitro digestion of forage crops. J. Brit. Grassl. Soc. 18:104-111.

Vallentine, J.F. and A.R. Stevens. 1994. Use of livestock to control cheatgrass-a review, p.202-206. In: S.B. Monsen and S.G. Kitchen (eds.) Proc.-Ecology and management of annual rangelands. 18-21 May 1992. Boise, Ida., USDA-FS Gen. Tech. Rep. INT-GTR 313. Ogden, Ut.

Whisenant, S.G. 1990. Postfire population dynamics of Bromus japonicus. Amer. Midl. Natur. 123:301-308.

White, L.M. 1985. Long-term residual effects of nitrogen fertilization on western wheatgrass. J. Range Manage. 38:461-466.

White, L.M., G.P. Hartman, and J.W. Bergman. 1981. In vitro digestibility, crude protein, and phosphorus content of straw of winter wheat, spring wheat, barley, and oat cultivars in eastern Montana. Agron. J. 73:117-121.

Wight, J.R. 1976. Range fertilization in the Northern Great Plains. J. Range Manage. 29:180-185. 


\title{
Suppression of annual bromes impacts rangeland: Animal responses
}

\author{
MARSHALL R. HAFERKAMP, ELAINE E. GRINGS, R.K. HEITSCHMIDT, MICHAEL D. MacNEIL, \\ AND MICHAEL G. KARL
}

Authors are rangeland scientist, research animal scientist, supervisory rangeland scientist, research geneticist, and postdoctoral rangeland scientist USDA-ARS, Fort Keogh Livestock and Range Research Laboratory, Miles City, Mont. 59301. Karl is currently rangeland management specialist, USDI-Bureau of Land Management, Washington, DC 20240.

\section{Abstract}

Presence of annual bromes (Bromus spp.), introduced annual weedy grasses, can alter seasonal patterns of forage production and quality and require management changes for efficient use of infested rangelands. We determined biological impacts of the presence of brome by comparing livestock performance on brome infested rangeland to similar sites on which brome had been suppressed by autumn application of atrazine [6-chloro-Nethyl-N'-(1-methylethyl)-1,3,5-triazine-2,4-diamine] at $0.56 \mathrm{~kg}$ $\mathrm{ha}^{-1}$ in 1992 and 1993. Each treatment was randomly assigned to three, 12-ha pastures. Vegetation was measured for 5 months (May to September) each year from 1993 to 1995. Each pasture was stocked with 8 crossbred steers of British breed origin (Bos taurus) from mid-May to mid-September 1993 and 1995 and to mid-August 1994. Initial body weights averaged $329 \mathrm{~kg} \mathrm{SD}=31$ in 1993, $273 \mathrm{~kg} \mathrm{SD}=14$ in 1994, and $272 \mathrm{~kg} \mathrm{SD}=21$ in 1995. Brome suppression and environment influenced plant species in diets, diet quality, and livestock performance. Brome suppression reduced percentage of annual grasses in diets from $14 \%$ to $10 \%$. Annual grasses were replaced in the diet by a variety of forb and grass species \{western wheatgrass [Pascopyrum smithii Rydb. (Love)], and blue grama [Bouteloua gracilis [H.B.K.] Lag. ex Griffiths]\}, with specific replacement depending on year and month. Steer gains were increased from 0.92 to $1.04 \pm 0.02 \mathrm{~kg}$ head $^{-1}$ day $^{-1}(\mathrm{P}<0.02)$ and from 69 to $81 \pm 2.8 \mathrm{~kg} \mathrm{ha}^{-1}(\mathrm{P}<0.05)$ with brome suppression. This experiment demonstrated that improvement in livestock performance can be expected with the suppression of annual bromes on semiarid rangelands.

Key Words: Bromus japonicus, Pascopyrum smithii, Northern Great Plains, crude protein yield

Annual bromes (Bromus spp.) have infested thousands of hectares of Northern Great Plains rangelands (Haferkamp et al. 1993, Whisenant 1990, Hewlett et al. 1981). Annual bromes affect associated plant species and nutritional quality of herbage

The authors express appreciation to Bryon Bennett, Caralee Leidholt, Chery Murphy, Duane Bundy, and several summer aids for field assistance, and Mary Ellen French and Diona Austill for assistance with graphics.

This paper is a contribution from the USDA-ARS and Montana Agr. Exp. Sta. Miles City, Mont.

The USDA-ARS, Northern Plains Area, is an equal opportunity/affirmative action employer, and all agency services are available without discrimination.

Manuscript accepted Jan. 27, 01

\section{Resumen}

La presencia de "Bromos" anuales invasores (Bromus spp.) puede alterar los patrones estacionales de producción y calidad de forraje y requieren cambios de manejo para hacer un uso eficiente de los pastizales infestados de las Grandes Planicies del Norte. Estudiamos los impactos biológicos de la presencia del "Bromo" mediante la comparación de pastizales infestados con sitios similares en los cuales el "Bromo" había sido suprimido con aplicaciones en otoño de atrazina [6-cloro-N-etil-N'-(1metiletil)-1,3,5-triazina-2,4-diamina] en dosis de $0.56 \mathrm{~kg} \mathrm{ha}^{-1}$ efectuadas en 1992 y 1993. Cada tratamiento se asignó aleatoriamente a tres potreros de 12 ha. De 1993 a 1995 la vegetación se midió anualmente durante 5 meses (Mayo a Septiembre). En 1993 y 1995, de mediados de Mayo a mediados de Septiembre, cada potrero se cargó con 8 novillos de cruzas comerciales (Bos taurus) y en 1994 se utilizaron hasta mediados de Agosto. El forraje base varió temporalmente por fecha y año, pero generalmente no fue menor de $800 \mathrm{~kg} \mathrm{ha}^{-1}$. La supresión de "Bromo" incrementó $(P<0.05)$ la concentración de proteína cruda del "Western wheatgrass" (Pascopyrum smithii Rydb. [Love]) en Julio (7.1 vs. 9.1\%) y Agosto (6.0 vs. $7.1 \%)$. Con la variación entre años de las poblaciones de "Bromo", por influencia de las condiciones durante el período de crecimiento, este experimento demostró que al suprimir el "Bromo" anual se puede esperar un mejoramiento en la calidad nutricional de los pastizales semiáridos.

available to grazing livestock (Haferkamp et al. 1994, 1997, 1998). The major characteristics of annual bromes affecting livestock management decisions include erratic fluctuations in annual forage production (Haferkamp et al. 2001, Haferkamp et al. 1993, Gartner et al. 1986), reduction in perennial plant production (Haferkamp et al. 1997, 1998, Rummell 1946), and early plant maturation (Haferkamp et al. 1994, Vallentine and Stevens 1994). Although early spring and autumn grazing are proposed as the best ways to use annual brome infested ranges (Mayland et al. 1994, Tipton 1994, Vallentine and Stevens 1994), some of these ranges must be used during the summer when forage nutritional quality of annual bromes may suppress livestock performance (Heitschmidt et al. 1993, Currie et al. 1989). The objective of this study was to test the hypothesis that summer rates of gain of steers grazing Northern Great Plains ranges infested with annual bromes would be less than gains of steers grazing adjacent ranges where annual brome abundance was suppressed. 


\section{Materials and Methods}

\section{Study Site}

Research was conducted at the Fort Keogh Livestock and Range Research Laboratory $\left(46^{\circ} 22^{\prime} \mathrm{N} 105^{\circ} 5^{\prime} \mathrm{W}\right)$ near Miles City, Mont. Elevation ranges from 716 to $853 \mathrm{~m}$. Regional topography ranges from rolling hills to broken badlands with small intersecting ephemeral streams flowing into rivers in broad, nearly level valleys. Annual precipitation averages $343 \mathrm{~mm}$, with about $60 \%$ received from April through September. Daily temperatures range from $>38^{\circ} \mathrm{C}$ during summer to $<-40^{\circ} \mathrm{C}$ during winter. The average frost-free growing season is 150 days. Indigenous vegetation on the 22,500-ha research station is a

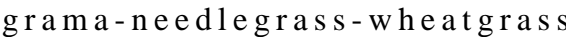
(Bouteloua-Stipa-Agropyron) mix (Kuchler 1964).

Soils at the specific-study site are a composite of Absher heavy clays (Fine, smectitic, frigid Leptic Torrertic Natrustalfs) and Gerdrum silty clay loams (Fine, smectitic, frigid Torretic Natrustalfs). Topography is gently sloping $(<2 \%)$. Vegetation is dominated by western wheatgrass (Pascopyrum smithii Rydb. [Love]), blue grama (Bouteloua gracilis [H.B.K.] Lag. ex Griffiths), Sandberg bluegrass (Poa secunda Presl.), sand dropseed (Sporobolus cryptandrus [Torr.] Gray), and Japanese brome (Bromus japonicus Thunb.). Threadleaf sedge (Carex filifolia Nutt.) is the dominant grasslike species. Dandelion (Taraxacum officinale Weber) and salsify (Tragopogon dubius Scop.) are the dominant forb species.

\section{Treatments and Experimental Design}

Six, 12-ha pastures were used in this study (Haferkamp et al. 2001). The 2 treatments (brome suppression and control) were assigned randomly to 6 pastures in a completely random design. Pasture was the experimental unit. Brome was suppressed with atrazine [6-chloro-N-ethylN'-(1-methylethyl)-1,3,5-triazine-2,4diamine] applied to dormant vegetation in November 1992 and 1993 at $0.56 \mathrm{~kg}$ a.i. $\mathrm{ha}^{-1}$. Herbicide was applied by ground in 1992 in 150 liters water ha ${ }^{-1}$ and by air in 1993 in 19 liters water ha ${ }^{-1}$. No herbicide was applied in autumn 1994.

\section{Livestock Sampling}

Each treatment was stocked annually with 8 crossbred yearling steers of British breed origin (Bos taurus) per 12-ha pasture. Pastures were stocked continuously from mid-May until mid-September 1993 and 1995. Limited forage production in 1994 resulted in a shortened grazing season extending from mid-May to midAugust. Steers were handled according to protocol approved by the Fort Keogh Livestock and Range Research Laboratory Animal Care Committee.

At the beginning of each grazing season steers were weighed. Steers were stratified by initial weight and within strata randomly assigned to pastures. Thereafter, weights were obtained about every 30 days, and at the end of each annual trial. Duration of the periods between sampling dates ranged from 23 to 37 days. Average daily gains were calculated from the weights taken at adjacent sampling dates and the duration of the respective period. Total gain was average daily gain multiplied times number of steers in the pasture and the number of days in the period. Gain per hectare was total gain divided by the area of the pasture. Shrunk weights on and off pastures were initiated in 1994 due to scale malfunction. Steers received a 200day estradiol implant in early May 1994 and 1995 , but not 1993 . Steers were treated with Ivermectin ${ }^{1}$ (Merck \& Co. Inc., Whitehouse Station, N.J.) before the study for parasite control and received a Python ${ }^{1}$ fly repellent ear tag (Y-TEX Corp., Cody, Wyo.) at the beginning of the grazing season. Steers were allowed ad libitum access to a loose trace mineralized salt mix containing $36 \% \mathrm{Cl}, 24 \% \mathrm{Na}, 6 \% \mathrm{P}, 5 \% \mathrm{Ca}$, 240 ppm Zn, 240 ppm Mn, 60 ppm Cu, 9 ppm I, 3 ppm Co, 0.9 ppm Se, 8800 IU vit$\operatorname{amin} \mathrm{A} \mathrm{kg}^{-1}$, and $880 \mathrm{IU}$ vitamin $\mathrm{D} \mathrm{kg}^{-1}$.

Diet quality was sampled monthly in all treatments during the week steers were weighed. Six to 8 esophageally cannulated crossbred heifers were used for diet sample collection. Diets were collected from at least 3 heifers per pasture, and not all pastures were sampled with the same heifers. Heifers were penned at 1600 hours with water but no feed available. Collections were made the following morning beginning at 0700 hours. Collection periods lasted from 20 to 30 min and were followed immediately by a collection in a second pasture. Esophageal masticate samples were thoroughly mixed by hand, freeze dried, and subsampled for diet quality and diet composition analyses. Sample collections began when these heifers were about 15 months of age.

\footnotetext{
${ }^{1}$ Mention of a trade name or a specific proprietary product does not constitute a guarantee or warranty by the authors or USDA-ARS nor does it imply the approval of these products to the exclusion of others.
}

Heifers had been cannulated at 2 months of age and were experienced with the diet collection process. Estrous was suppressed during diet collection periods by the use of a Norgestomet ${ }^{1}$ implant (Sanofi Animal Health, Overland Park, Kan.). Between sampling periods, heifers were kept in larger pastures with a variety of range sites. Heifers had been previously exposed to all plant species present in the experimental pastures.

\section{Laboratory Analysis}

Esophageal masticate and standing crop samples (Haferkamp et al. 2001) were ground to pass through a 1-mm screen in a Wiley mill ${ }^{1}$ (Arthur H. Thomas Co., Philadelphia, Penn.). Total nitrogen (N; organic matter basis) was determined with a Technicon ${ }^{1}$ Auto Analyzer (Technicon Industrial Systems 1977, Tarrytown, N.Y.). Data are presented as percentage crude protein (CP; percentage $\mathrm{N}^{*} 6.25$ ) and $C P$ yield (standing crop*decimal equivalent $\mathrm{CP}$ ). In vitro digestible organic matter (IVDOM) was determined using a modified Tilley and Terry (1963) technique (White et al. 1981).

Diet composition by plant species was determined using a point-frame technique on unground samples of lyophilized tissue (Angell et al. 1986). The fragment hit at each point was identified and recorded. If no hit occurred, the closest fragment to the pin point in a forward 180-degree arc was used. Each sample was assessed at 100 points.

\section{Data Summarization and Analysis}

Analysis of variance was used to test effects of treatments, years, dates, and interactions among them. Treatment effects were tested with the residual variation among pastures within treatment, and years and the year by treatment interaction were tested with the year by pasture within treatment interaction. Effects of dates and interactions of dates with other effects were tested with the residual variation after accounting for all other effects in the model.

Data for the fourth sampling period in 1994 were missing, thus the marginal means for treatment were non-estimable. However, treatment by period subclass means were estimable. Means were compared using the Least Significant Difference method protected by a significant F-statistic $(\mathrm{P} \leq 0.05)$ from the analysis of variance (SAS 1990).

Comparisons for CP yield were limited to May, June, July, and August, due to the 
lack of September samples in 1994. Most analyses were run on the following species groups: Western wheatgrass + Sandberg bluegrass, other perennial grasses, annual grasses, sedges, forbs, total green biomass, standing dead, and total biomass.

\section{Results and Discussion}

\section{Brome Suppression \\ Standing Crop}

Impact of brome suppression on standing crop ( $\mathrm{kg} \mathrm{DM} \mathrm{ha}{ }^{-1}$ ) and forage nutritive value have been reported previously (Haferkamp et al. 2001). Findings showed annual brome suppression with atrazine had the following effects: decreased standing crop of annual grasses $(\mathrm{P} \leq 0.05)$, total vegetation $(\mathrm{P} \leq 0.05$ for year by treatment by date interaction), and total vegetation plus standing dead ( $\mathrm{P} \leq 0.05$ for year by treatment by date interaction) and increased forage nutritive value of western wheatgrass $(\mathrm{P} \leq 0.05)$ and Japanese brome $(\mathrm{P} \leq 0.05)$ as indicated by increases in CP. Significant interactions with date and year showed that these responses would vary with the changing environmental conditions both within and across years.

\section{Crude Protein Yield}

Animal performance can be limited by either forage quality or quantity. Total yield of nutrients is an important way to evaluate treatment effects for their potential to impact animal gains. Crude protein yields $\left(\mathrm{kg} \mathrm{CP} \mathrm{ha}^{-1}\right)$ of annual grasses were somewhat constant among dates and years when brome was suppressed, but yields varied among dates and years with brome present (Fig. 1A and B). Magnitude of treatment differences declined from spring to late summer (Fig. 1A). Crude protein yield of annual grass was increased $(\mathrm{P} \leq$ $0.01)$ by presence of bromes in 1993 and 1995, but not 1994 (Fig. 1B).

\section{Steer Diets}

Brome suppression decreased percentage of annual grasses in the diet from $14 \%$ to $10 \%(\mathrm{P} \leq 0.01)$. The dietary proportion of other perennial grass was reduced by brome suppression in May and August but not June or July (Table 1). With brome suppression, much of the dietary annual grasses were replaced by western wheatgrass even though brome suppression did not affect the western wheatgrass + Sandberg bluegrass group, the dominant component of steer diets (57\%). There was also some replacement by forbs and blue

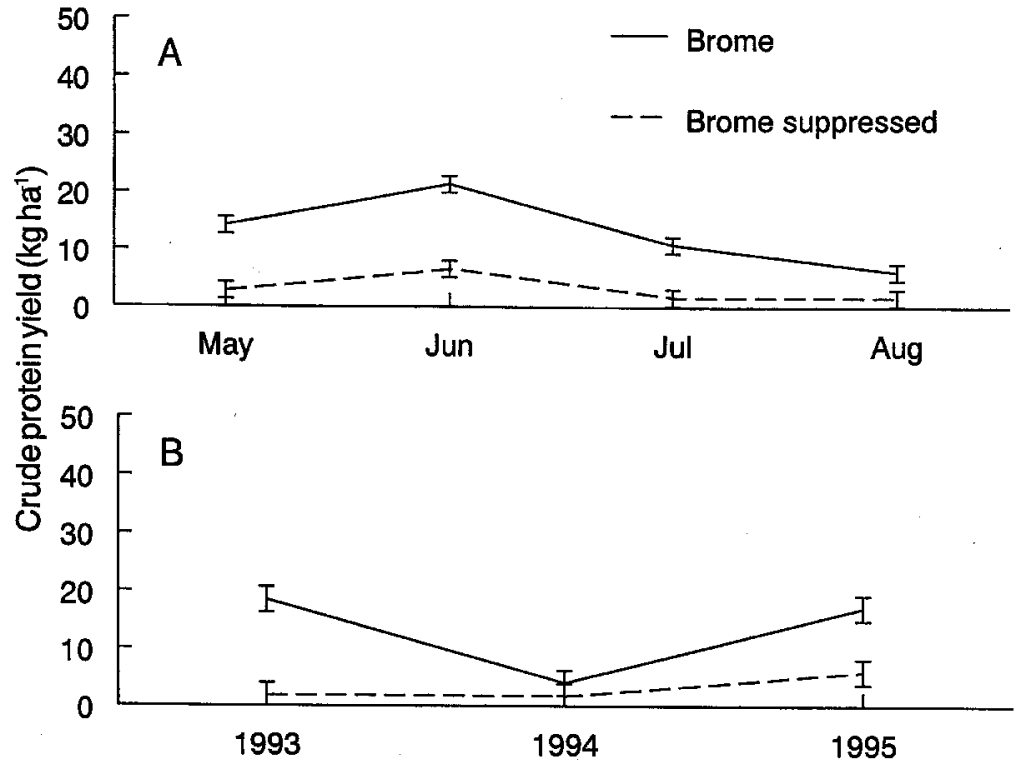

Fig. 1. Least-square-means and standard errors for CP yield ( $\mathrm{kg} \mathrm{ha}^{-1}$ ) for significant (A) date by brome suppression $(\mathrm{P} \leq \mathrm{0.01})$ and $(\mathrm{B})$ year by brome suppression interactions for annual grasses $(\mathbf{P} \leq \mathbf{0 . 0 1})$.

grama at various times. Specific replacement depended upon year and month.

Neither diet CP concentration $(13.3 \%)$ nor IVDOM $(68.5 \%)$ was affected by brome suppression. Moreover no interactions with treatment affecting diet quality were significant.

\section{Steer Gains}

Initial weight of steers averaged $329 \mathrm{~kg}$ $(\mathrm{SD}=31)$ in $1993,273 \mathrm{~kg}(\mathrm{SD}=14)$ in 1994 (12-hour with water shrunk weight), and $272 \mathrm{~kg}(\mathrm{SD}=21)$ in 1995 . Steer average daily gains during the May to September grazing season were increased ( $\mathrm{P} \leq 0.05)$ from 0.92 to $1.04 \pm 0.02 \mathrm{~kg}$ head $^{-1}$ day $^{-1}$, and gains per hectare were increased $(\mathrm{P} \leq 0.05)$ from 69 to $81 \pm 2.8$ $\mathrm{kg} \mathrm{ha}^{-1}$ by brome suppression. The treatment by year interaction was not significant for steer gains. Hart et al. (1995) reported that with put and take stocking, atrazine tended to increase carrying capacity and gain $\mathrm{ha}^{-1}$, but not average daily gain

Table 1. Least-square-means and SE for date by brome suppression treatment interaction for percentage of other perennial grass component in steer diets.

\begin{tabular}{|c|c|c|c|c|}
\hline \multirow{2}{*}{$\begin{array}{l}\text { Brome } \\
\text { treatment }\end{array}$} & \multicolumn{4}{|c|}{ Date } \\
\hline & May & June & July & August \\
\hline & \multicolumn{4}{|c|}{ 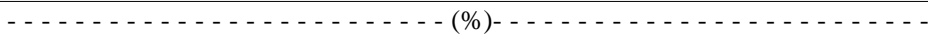 } \\
\hline Undisturbed & $17^{\mathrm{BCa} 1}$ & $12^{\mathrm{Ca}}$ & $18^{\mathrm{Ba}}$ & $25^{\mathrm{Aa}}$ \\
\hline Suppressed & $11^{\mathrm{Cb}}$ & $15^{\mathrm{BCa}}$ & $24^{\mathrm{Aa}}$ & $19^{\mathrm{ABb}}$ \\
\hline SE & \multicolumn{4}{|c|}{1.9} \\
\hline
\end{tabular}

${ }^{1}$ Comparison of date effect for each brome suppression treatment (within a row) is indicated by uppercase superscripts. Comparison of treatment effect for each date (within a column) is indicated by lowercase superscripts. Means with similar superscripts are not significantly different $(\mathrm{P} \leq 0.05)$. or average returns to land, labor, or management on blue grama dominated range in eastern Colorado. They suggested that with optimum stocking rates, atrazine might increase returns (heavy stocking early in the season and lighter stocking later).

\section{Environmental Effects \\ Crude Protein Yield}

Crude protein yields of annual grasses were greater with brome in the wetter years of 1993 and 1995 than in 1994 (Fig. 1B). Crude protein yields varied significantly among dates within years for western wheatgrass + Sandberg bluegrass (Fig. 2A), other perennial grasses (data not shown), standing dead (Fig. 2B), and total vegetation (Fig. 2C). The dominance of western wheatgrass in this plant community is clearly shown by the similarity of $\mathrm{CP}$ yield between western wheatgrass + Sandberg bluegrass (Fig. 2A) and total vegetation (Fig. 2C). Crude protein yield of standing dead (Fig. 2B) averaged $6.3 \mathrm{~kg}$ 


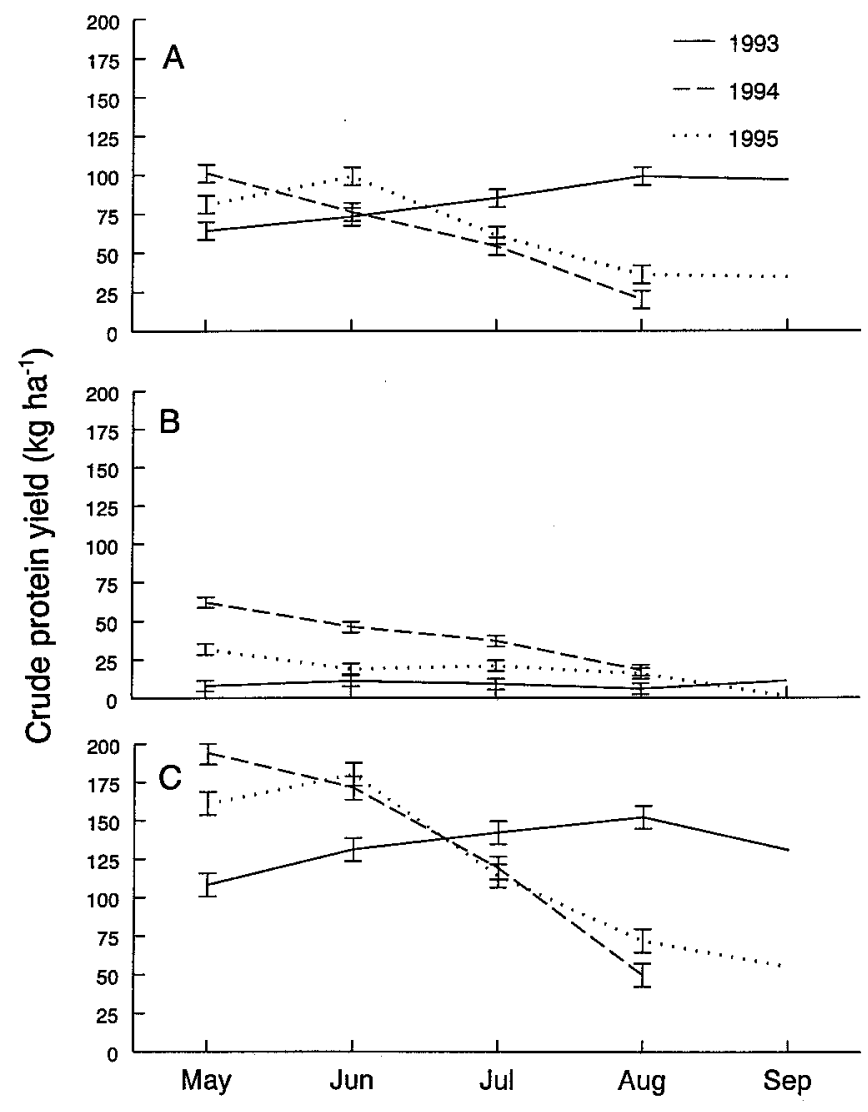

Fig. 2. Least-square-means and standard errors for $\mathrm{CP}$ yield $\left(\mathrm{kg} \mathrm{ha}^{-1}\right)$ for significant year by date interaction for (A) western wheatgrass + Sandberg bluegrass $(P \leq 0.01),(B)$ standing dead $(P \leq$ $0.01)$, and $(C)$ total biomass $(P \leq 0.01)$. September data for 1993 and 1995 are included for visual comparisons, but these data were not included in statistical analyses.

$\mathrm{ha}^{-1}$ among dates and changed little in 1993, but decreased 44 and $16 \mathrm{~kg} \mathrm{ha}^{-1}$ with advancing date in 1994 and 1995. The relatively small CP yield for standing dead in
1993 was partially related to grazing standing crop to a short stubble in late summer 1992 prior to applying atrazine. In contrast ample precipitation produced

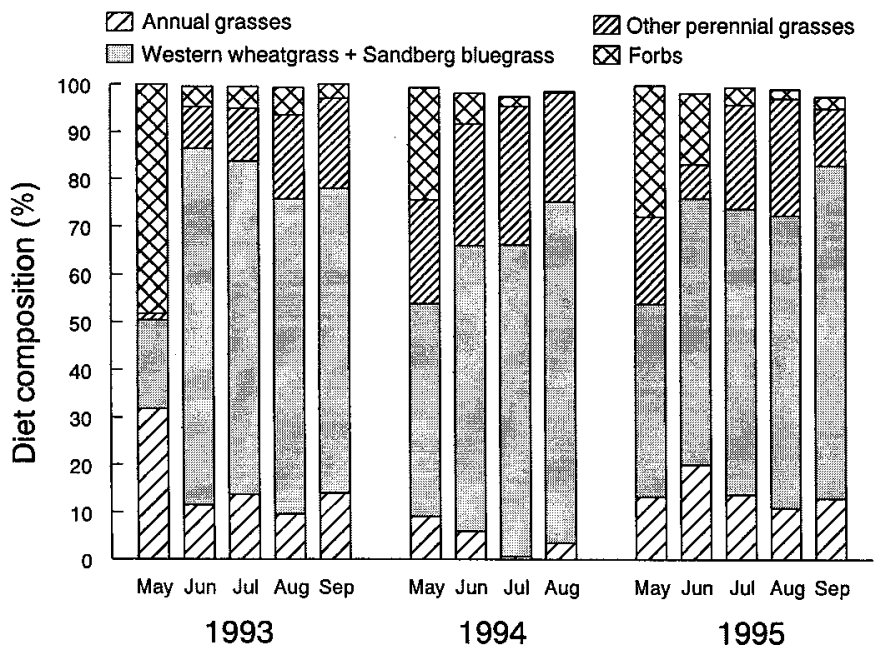

Fig. 3. Least-square-means for percentage diet composition for significant $(P \leq 0.05)$ year by date interactions. September data for 1993 and 1995 are included for visual comparisons, but these data were not included in statistical analyses. large amounts of herbage in 1993 that was converted to standing dead in 1994. An intermediate amount of herbage was converted to standing dead in 1995.

\section{Steer Diets}

Percentages of plant species groups contained in steer diets varied with date among year (Fig. 3). Maximum proportions of annual grasses in the diet occurred in May 1993. Although dietary content of annual grasses declined $(\mathrm{P} \leq 0.01)$ from May to June 1993, percentages were similar among remaining dates in 1993 and all dates in 1994 and 1995. In addition to May, distinct year differences were also noted in July when only $1 \%$ annual grass was present in diets in 1994 compared with $14 \%$ in 1993 and 1995. This is a reflection of the small amount of annual grass available in the 1994 standing crop (<30 kg ha $\left.{ }^{-1}\right)$. Cool-season perennial grasses (western wheatgrass and Sandberg bluegrass $)$ in the diet increased $(\mathrm{P} \leq 0.01)$ from May each year, with dietary proportions being similar during the remainder of the grazing season. The amount of other perennial grasses in the diet increased $(\mathrm{P} \leq$ 0.01) from May 1993, but differences among dates were not as distinct in 1994 and 1995.

In 1993, CP concentration in diets declined from May to July but increased in August to levels similar to June (Fig. 4B). Crude protein of diets declined from May to August in 1994 and 1995. Digestibility decreased with advancing date each year (Fig. 4A). The year differences, higher quality in 1993, clearly show the influence of growing-season precipitation on diet quality.

\section{Steer Gains}

Most of the variation in steer gains exhibited in Table 2 can be explained by utilization of shrunk weight on and off pastures in 1994 and previously described variation in amount and distribution of precipitation and the subsequent impact on the quantity and nutritional quality of forage (Haferkamp et al. 2001). Average daily gains were consistently greater in the first half than the second half of the grazing season, and due to the shrink, gains decreased more rapidly in the 1994 season than in the wetter 1993 and 1995 seasons (Table 2). May to June daily gains were least in 1993 when May precipitation was below average, whereas 1993 late season gains were highest or equal to gains in 1995 in response to cool temperatures and above average precipitation. Gain aver- 
Table 2. Least-square-means and SE for significant year by date interaction for steer gains and average duration of each grazing period.

\begin{tabular}{|c|c|c|c|c|}
\hline \multirow[t]{2}{*}{ Year } & \multicolumn{4}{|c|}{ Date and average length of grazing periods } \\
\hline & $\begin{array}{l}\text { May } \\
\text { June } \\
\text { (25 days) }\end{array}$ & $\begin{array}{l}\text { June } \\
\text { July } \\
\text { (30 days) }\end{array}$ & $\begin{array}{l}\text { July } \\
\text { August } \\
\text { (33.3 days) }\end{array}$ & $\begin{array}{l}\text { August } \\
\text { September } \\
\text { (34.5 days) }\end{array}$ \\
\hline & \multicolumn{4}{|c|}{$\ldots \ldots\left(\mathrm{kg} \mathrm{head}^{-1} \mathrm{day}^{-1}\right) \ldots \ldots$} \\
\hline 1993 & $1.41^{\mathrm{Ac}}$ & $1.38^{\mathrm{Aa}}$ & $0.79^{\mathrm{Ba}}$ & $0.61^{\mathrm{Ca}}$ \\
\hline 1994 & $2.05^{\mathrm{Aa}}$ & $1.17^{\mathrm{Bb}}$ & $0.27^{\mathrm{Cb}}$ & - \\
\hline 1995 & $1.86^{\mathrm{Ab}}$ & $1.19^{\mathrm{Bb}}$ & $0.80^{\mathrm{Ca}}$ & $0.29^{\mathrm{Db}}$ \\
\hline SE & \multicolumn{4}{|c|}{0.06} \\
\hline
\end{tabular}

${ }^{T}$ Comparison of year effect for each grazing period (within a row) is indicated by upper case superscripts. Comparison of date effect for each year (within a column) is indicated by lower case superscripts. Means with similar superscripts are not significantly different $(\mathrm{P} \leq 0.05)$.

aged $82 \mathrm{~kg} \mathrm{ha}^{-1}$ in 1993 and 1995 but was less $(\mathrm{P} \leq 0.01)$ in $1994\left(60 \mathrm{~kg} \mathrm{ha}^{-1}\right)$ due to the truncated grazing season. This difference $(\mathrm{P} \leq 0.01)$ was shown in the May to August gain data collected for the 3 years. May to August gains averaged $70 \pm 1.3 \mathrm{~kg}$ $\mathrm{ha}^{-1}$ in $1993,60 \pm 1.3 \mathrm{~kg} \mathrm{ha}^{-1}$ in 1994 , and $74 \pm 1.3 \mathrm{~kg} \mathrm{ha}^{-1}$ in 1995 . Daily gains were similar to those reported by Grings et al. (1996) for steers grazing other pastures at Fort Keogh during the same time period. They found steers gained from 1.3 to 1.5 $\mathrm{kg} \mathrm{head}^{-1}$ day $^{-1}$ during May to September 1993, May to July 1994, and May to August 1995. In contrast, steers gained 0.6 to $1 \mathrm{~kg} \mathrm{head}^{-1} \mathrm{day}^{-1}$ when grazing September to October 1993, July to September 1994, and August to September 1995

\section{Conclusions}

Findings reported here and in Haferkamp et al. (2001) show annual brome suppression with atrazine has the following effects: decreased standing crops of annual grasses, total vegetation and total vegetation plus standing dead; increased forage nutritive value of western wheatgrass and Japanese brome; and decreased proportions of annual grasses and other perennial grasses in diets. Interactions with date and year suggest that these responses will vary with the changing environmental conditions both within and among years.

Gains of stocker cattle were increased about $16 \%$ by suppression of annual brome on Northern Great Plains ranges. The untreated pastures were uniformly

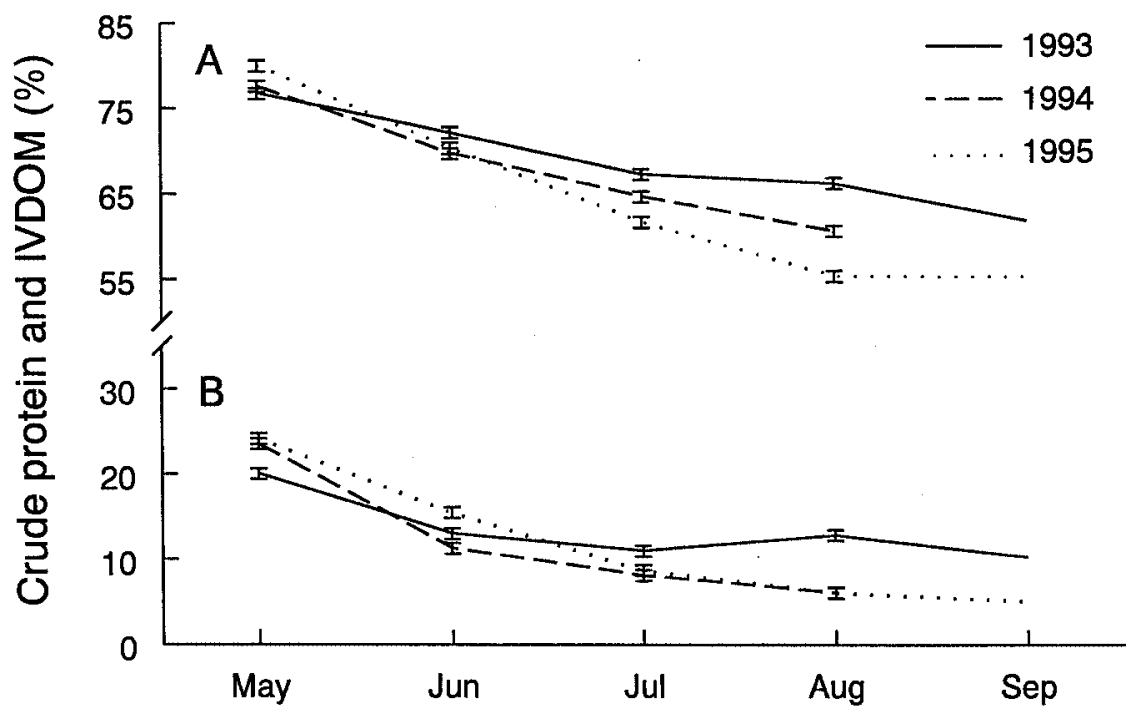

Fig. 4. Least-square-means and standard errors for percentage diet $\mathrm{CP}$ concentration $(\mathbf{P} \leq \mathbf{0 . 0 1})$ and percentage IVDOM $(P \leq \mathbf{0 . 0 1})$ for significant year by date interaction. September data for 1993 and 1995 are included for visual comparisons, but these data were not included in statistical analyses. infested by annual bromes, but standing crop of annual grasses was small relative to other years on this site (Haferkamp et al. 2001). Thus, the increase in livestock performance with annual brome suppression might be greater with larger brome standing crop or higher composition of annual bromes, but it might be smaller when steers graze large pastures with spotty distribution of annual bromes. The botanical composition of pastures used for summer grazing yearling cattle should be evaluated before devising management strategies to maximize efficiency of utilization of Northern Great Plains rangelands.

\section{Literature Cited}

Angell, R.F., J.W. Stuth, and D.L. Drawe. 1986. Diets and live weight changes of cattle grazing fall burned gulf cordgrass. J. Range Manage. 39:233-236.

Currie, P.O., J.D. Volesky, D.C. Adams, and B.W. Knapp. 1989. Growth patterns of yearling steers determined from daily live weights. J. Range Manage. 42:393--396.

Gartner, F.R., E.M. White, and R.I. Butterfield. 1986. Mechanical treatment and burning for high quality range forage, p.135-140. In: South Dakota Beef Report, Animal Range Sciences Dept., Agr. Exp. Sta., Coop. Ext. Serv., South Dakota State Univ., Brookings, S. Dak.

Grings, E.E., R.K. Heitschmidt, R.E. Short, B.S. Hould, and N.R. Bellows. 1996. Management strategies for grazing yearling cattle in the Northern Great Plains. Proc. West. Sec. Amer. Soc. Anim. Sci. 47(Suppl. 1): 145 .

Haferkamp, M.R., R.K. Heitschmidt, and M.G. Karl. 1997. Influence of Japanese brome on western wheatgrass yield. J. Range Manage. 50:44-50.

Haferkamp, M.R., R.K. Heitschmidt, and M.G. Karl. 1998. Clipping and Japanese brome reduce western wheatgrass standing crop. J. Range Manage. 51:692-698.

Haferkamp, M.R., R.K. Heitschmidt, E.E. Grings, M.D. MacNeil, and M.G. Karl. 2001. Suppression of annual bromes impacts rangeland: Vegetation responses. J. Range. Manage. 54:656-662.

Haferkamp, M.R., J.D. Volesky, M.M. Borman, R.K. Heitschmidt, and P.O. Currie. 1993. Effects of mechanical treatments and climatic factors on the productivity of Northern Great Plains rangelands. J. Range Manage. 46:346-350.

Haferkamp, M.R., J.A. Young, E.E. Grings, M.G. Karl, R.K. Heitschmidt, and M.D. MacNeil. 1994. Japanese brome in the Northern Great Plains, p.396-401. In: S.B. Monsen and S.G. Kitchen (eds.) Proc.Ecology and management of annual rangelands. 18-21 May 1992. Boise, Ida., USDAFS Gen. Tech. Rep. INT-GTR 313. Ogden, Ut. 
Hart, R.H., M.C. Shoop, and M.M. Ashby. 1995. Nitrogen and atrazine on shortgrass: Vegetation, cattle, and economic responses. J. Range Manage. 48:165-171.

Heitschmidt, R.K., J.D. Volesky, M.R. Haferkamp, and P.O. Currie. 1993. Steer performance on native and mechanically modified Northern Great Plains rangeland. J. Range Manage. 46:529-533.

Hewlett, D.B., J.R. Johnson, R.I. Butterfield, and V.K. Mosley. 1981. Japanese brome response to atrazine in combination with nitrogen fertilizer in the mixed prairie. J. Range Manage. 34:22-25.

Kuchler, A. W. 1964. Potential natural vegetation of the conterminous United States. Amer. Geog. Soc. Spec. Pub. 36. Amer. Geog. Soc. New York, N.Y.

Mayland, H.F., R.B. Murray, and G.E. Shewmaker. 1994. Forage yields and quality trends of annual grasses in the Great Basin, p.387-391. In: S.B. Monsen and S.G. Kitchen (eds.) Proc. Ecology and management of annual rangelands. 18-21 May 1992. Boise, Ida., USDA-FS Gen. Tech. Rep. INTGTR 313. Ogden, Ut.
Rummell, R.S. 1946. Some effects of competition from cheatgrass brome on crested wheatgrass and bluestem wheatgrass. Ecol. 27:159-167.

SAS. 1990. SAS/STAT user's guide. Vol. 2, Version 6 (4th Ed.). SAS Inst. Inc. Cary, N.C. Technicon Industrial Systems. 1977. Digestion and sample preparation for the analysis of total Kjeldahl nitrogen/phosphorus using the Technicon BD-20 block digester. Technicon Autoanalyzer II Methodology. Industrial Method No. 369-75 A/B. Technicon Industrial Systems. Tarrytown, N.Y.

Tilley, J.M.A. and R.A. Terry. 1963. A twostage technique for the in vitro digestion of forage crops. J. Brit. Grassl. Soc. 18:104-111

Tipton, F.H. 1994. Cheatgrass, livestock, and rangeland, p.414-416. In: S.B. Monsen and S.G. Kitchen (eds.) Proc. Ecology and management of annual rangelands. 18-21 May 1992. Boise, Ida., USDA-FS Gen. Tech. Rep. INT-GTR 313. Ogden, Ut.
Vallentine, J.F. and A.R. Stevens. 1994. Use of livestock to control cheatgrass-a review, p.202-206. In: S.B. Monsen and S.G. Kitchen (eds.) Proc. Ecology and management of annual rangelands. 18-21 May 1992. Boise, Ida., USDA-FS Gen. Tech. Rep. INTGTR 313. Ogden, Ut.

Whisenant, S.G. 1990. Postfire population dynamics of Bromus japonicus. Amer. Midl. Natur. 123:301-308.

White, L.M., G.P. Hartman, and J.W. Bergman. 1981. In vitro digestibility, crude protein, and phosphorus content of straw of winter wheat, spring wheat, barley, and oat cultivars in eastern Montana. Agron. J. 73:117-121. 


\title{
Chemical composition and livestock ingestion of carob (Ceratonia siliqua L.) seeds
}

\author{
MOH'D KHAIR J. EL-SHATNAWI AND KHALIL I. EREIFEJ
}

Authors are associate professor, Department of Natural Resources and the Environment, Faculty of Agriculture, Jordan University of Science and Technology, PO Box 3030, Irbid, Jordan, E-mail: mkhair@just.edu.jo, and professor, Department of Nutrition and Food Technology, Faculty of Agriculture, Jordan University of Science and Technology, PO Box 3030, Irbid, Jordan, E-mail: ereifej@just.edu.jo.

\begin{abstract}
Pods and seeds from carob Ceratonia siliqua $\mathbf{L}$. trees growing in Ajloun Mountainous forests and rangelands in Jordan were analyzed for their proximate analysis, $\mathrm{Ca}$ and $\mathrm{P}$ contents, and also the effects of ingestion of seeds by sheep and goat on the germination were investigated. Carob seed has hard seed coat dormancy, and seed scarification increased germination from $10.2 \%$ in non-scarified to $85.4 \%$ after scarification. Germination percentages for seeds that were ingested by sheep were $73.5,61.8$, 39.3 , and $0.0 \%$ for ingestion periods of $24,48,72$, and 96 hours, respectively; whereas, it was $56.8,79.9,50.1,13.7$, and $1.1 \%$ for seeds dispersed from goat after 24, 48, 72, 96, and 120 hours. Carob seeds contained higher amounts of protein, fiber, fat and Ca than deseeded pods. However, the latter contained more carbohydrates and $\mathbf{P}$ than seeds. Carob pods and seeds contained sufficient crude protein and energy to meet the maintenance and lactation requirements of ewes, but $\mathrm{Ca}$ and $\mathrm{P}$ contents were not adequate by themselves.
\end{abstract}

Key Words: Germination, fiber, forest, goat, Jordan, protein, sheep

Carob pods are produced by the evergreen sclerophyllous tree Ceratonia siliqua L., a species that is native to western Asia and northern Africa. Various chemical and physiological aspects of carob plants have been investigated in many countries around the world (Coit 1967, Orphanos and Papaconstantinou 1969, Calixto and Canellas 1982, Wursch 1987, Gaitis et al. 1994, Marakis 1996). Although carob trees are found in great abundance in Jordanian forests and rangelands, thorough investigations on its use as feed source in sheep industry are very rare.

Animals acting as seed dispersal agents are instrumental in maintaining and spreading woody plant populations (Janzen 1983), and ungulates often play an important role in this context. Ruminants, including sheep and goat, consume considerable amounts of carob fruits. Carob provides nutritious pods and extremely hard, smooth seeds that may evade or resist strong molars. Seeds of many forest trees regularly pass through the digestive tracts of animals unharmed. However, the digestive juices of many animals may weaken the seed coat and favor

We thank Dr. Hani Z. Ghosheh for his critical comments, helpful suggestions and editorial inputs.

Manuscript accepted 16 Dec. 00.

\section{Resumen}

Vainas y semillas de "Carob" (Ceratonia siliqua L.) colectadas de árboles de los bosques montañosos y pastizales de Ajloun se sometieron al análisis proximal y se les determinó su contenido de Ca y P. Además, en este estudio se investigaron los efectos de la ingestión de la semilla por ovinos y caprinos en la geminación. La semilla de "Carob" manifiesta una dormancia por la presencia de una capa dura, y la escarificación de la semilla incrementó la geminación de $10.2 \%$ a $85.4 \%$. Los porcentajes de germinación de la semilla ingerida por ovinos fueron de $73.5,61.8$, 39.3, and $0.0 \%$ para los períodos de ingestión de $24,48,72$ and 96 horas, respectivamente, mientras que los porcentajes fueron de 56.8, 79.9, 50.1, 13.7 y 1.1\% para las semilla dispersadas por los caprinos después de 24, 48, 72, 96 y 120 horas. Las semillas de "Carob" mostraron mayores cantidades de proteína, fibra, grasa y calcio que las vainas sin semilla. Sin embargo, estas últimas presentaron más carbohidratos y $\mathbf{P}$ que las semillas. Las semillas y vainas de "Carob" contenían suficiente proteína cruda y energía para satisfacer los requerimientos de mantenimiento y lactancia de las borregas, pero los contenidos de Ca y $\mathbf{P}$ no fueron adecuados.

water absorption and eventually, germination (Barnes et al. 1998). Seeds may be destroyed by mastication and digestion (Thill et al. 1986) or dispersed to new sites. In this context several investigators have studied carob trees, pods (beans) and their seeds (Marakis 1980, Brito de Carvalho 1987, Marakis et al. 1993).

Carob trees dominate the vegetation of many sites of the mountainous Ajloun forests. Unfortunately, the nutritive value of carob seeds and pods, and the effects of livestock on the viability of the seeds were not investigated in Jordan. Therefore, the objective was to study the chemical compostion of the carob seeds and pods, and to investigate the effect of carob seeds ingestion by sheep and goat.

\section{Materials and Methods}

\section{Site Description}

The carob trees which are the focus of this study are located on the Ajloun mountains in northern Jordan, situated $35 \mathrm{~km}$ south of Irbid $\left(32^{\circ} 21^{\prime} \mathrm{N}, 35^{\circ} 49^{\prime} \mathrm{E}\right)$. Altitude is $920 \mathrm{~m}$ and the site is characterized by having 30 to $70 \%$ slope. The soil is a weakly cracked and deep silty clay. Natural vegetation is typical of 
Mediterranean forests dominated by oak (Quercus spp.) and/or carob (Ceratonia siliqua) trees (Anon 1998). Mean annual precipitation for that site is $500 \mathrm{~mm}$ occurs during October to April. Highest accumulations and the most rapid plant growth occurred during the period from January to March and ceases during May (Anon 1997).

\section{Chemical analysis}

In 1995 and 1996, mature carob pods were collected from 72 trees. Crude protein ( $\mathrm{N} X$ 6.25), fat, fiber, and ash contents, were determined in pods and seeds according to AOAC (1984) procedures. Carbohydrates were calculated by difference as follows: \% Carbohydrate $=100$ $(\%$ Protein $+\%$ Fat $+\%$ Fiber $+\%$ Ash $)$. Calcium $(\mathrm{Ca})$ contents of pods and seeds were determined with an atomic absorption spectrophotometer (Unicam, model SP9, UK) using the wet digestion method with a mixture of nitric, sulfuric and perchloric acids (10:1:4). Phosphorus (P) content in pods and seeds was determined according to Watanabe and Olsen (1965). All chemical composition are reported on dry weight basis. No significant differences for all measured traits were detected between the 2 seasons and data from the 2 growing seasons were therefore combined and subjected to analysis of variance according to Steel and Torrie (1980).

\section{Germination of Dispersed Seeds}

Ten, 4-year old sheep ewes and goats were housed into 2 separate pens $\left(40 \mathrm{~m}^{2}\right)$ for the purpose of this experiment. These animals were fed on wheat straw and ground barley. The animals were not given any food for 24 hours before starting the experiment, so that the animals would consume large amounts of carob seeds. Carob pods were hand-chopped into 3-4 pieces, and were provided to animals for 4 hours. Sheep and goats were then transferred to 2 separate clean pens to avoid contamination from non-fed carob seeds. Manure was collected 24, 48, 72, 96, and 120 hours after dosing. At the end of each collecting period, seeds were separated and washed from the manure.

Germination tests were conducted on carob seeds that were either scarified by abrasive glass paper, non-scarified, or animal dispersed. For each treatment, ten petridishes $(15 \times 1.5 \mathrm{~cm})$ were used, each contained 10 carob seeds and were incubated at $20^{\circ} \mathrm{C}$ for 14 days. Treatments of scarified carob seeds, non-scarified, and the combination of live stock type (sheep or goat) and dispersal time $(24,48,72,96$, or 120 hours) were arranged in a randomized complete block design with ten replications. Germinated seeds were counted every 24 hours. Germination percentage means were separated and compared according to the least significant difference (LSD) test as described by Steel and Torrie (1980). Polynomial Regression Model for germination \% as dependent variables and ingestion period length at stomach of sheep or goat as independent variable was carried as described by Neter et al. (1989).

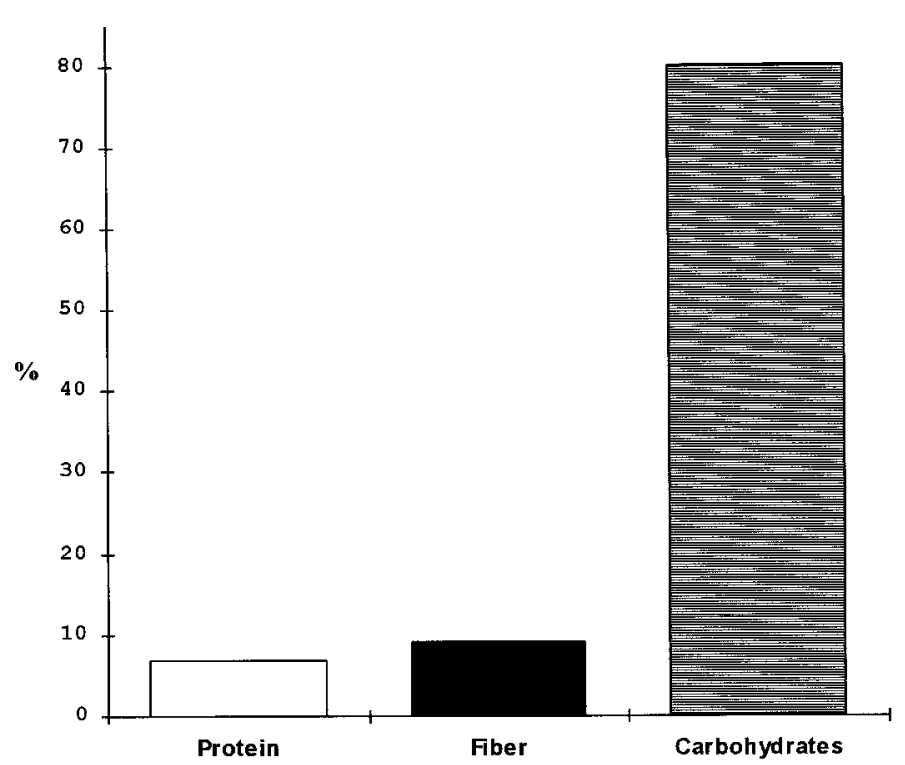

Fig. 1. Protein, fiber and carbohydrates composition of carob (Ceratonia siliqua L) pods collected from Ajloun forests rangeland.

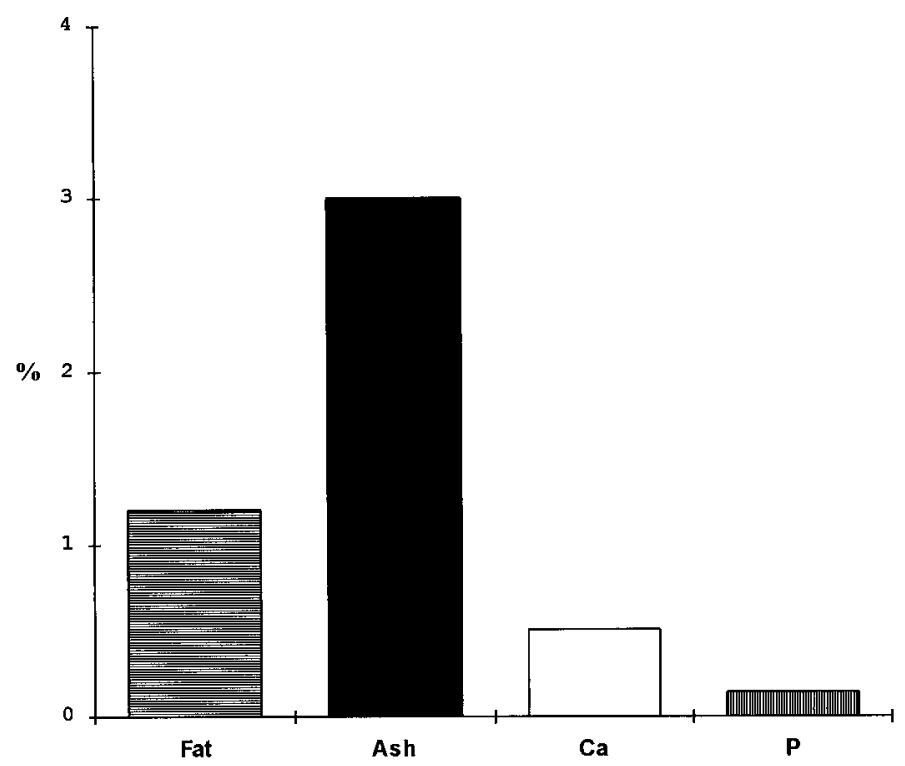

Fig. 2. Fat, ash, Ca and $P$ composition of carob (Ceratonia siliqua $L$ ) pods collected from Ajloun forests rangeland. 


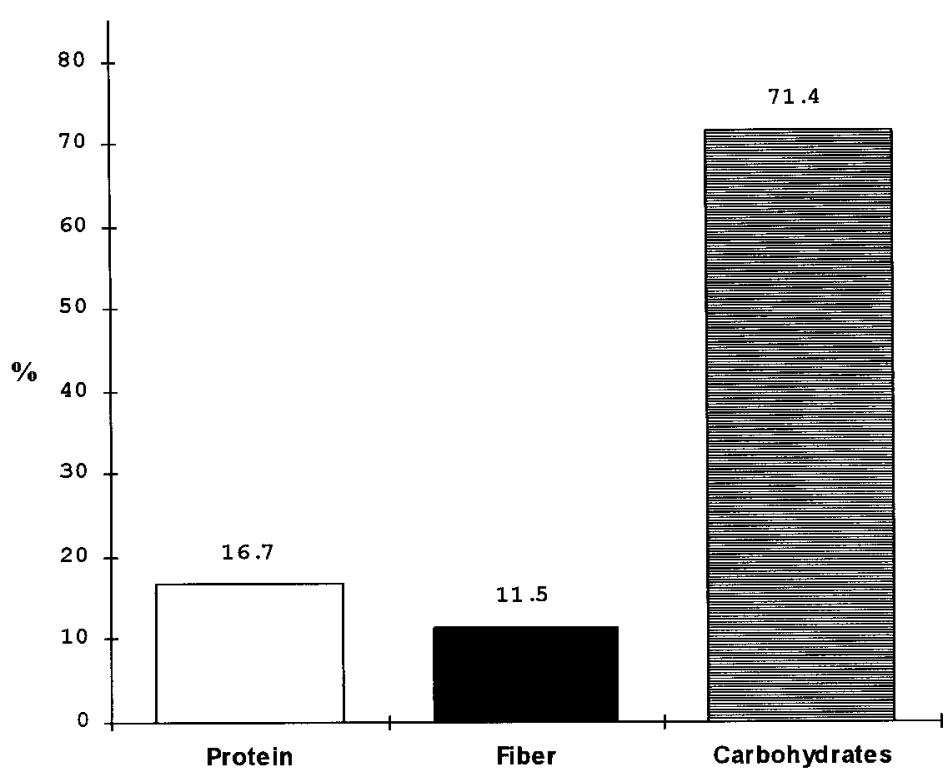

Fig. 3. Protein, fiber and carbohydrates composition of carob (Ceratonia siliqua $\mathrm{L}$ ) seeds collected from Ajloun forests rangeland.

1.2 and $2.9 \%$, respectively (Fig. 2 and 4 ). Considerable variations were observed in ash contents between pods and seeds (3.0 vs. $0.4 \%$ ash content) (Fig. 2 and 4 ). Calcium contents were $493(0.5 \%)$ and $674 \mathrm{mg} 100 \mathrm{~g}^{-1}(0.7 \%)$ in carob pods and seeds, whereas phosphorus content (Fig. 2 and 4) was $146 \mathrm{mg} 100 \mathrm{~g}^{-1}(0.15 \% \%)$ in carob pods, but $125 \mathrm{mg} 100 \mathrm{~g}^{-1}(0.13 \%)$ in seeds. Ca:P ratios were 5.1 and 6.4 in pods and seed, respectively (Fig. 5).

\section{Germination of Dispersed Seeds}

Germination of non-scarified seeds was $10.2 \%$, whereas the scarified germination was $85.4 \%$ (Fig. 6). Germination percentages for the seeds which were ingested by sheep and collected after 24, 48, 72 and 96 hours after ingestion were 73.5, 61.8, 39.3, and $0.0 \%$, respectively. Germination percentages were $56.8,79.9,50.1,13.7$, and $1.1 \%$ for seeds ingested by goats and dispersed after 24, 48, 72, 96, and 120 hours,

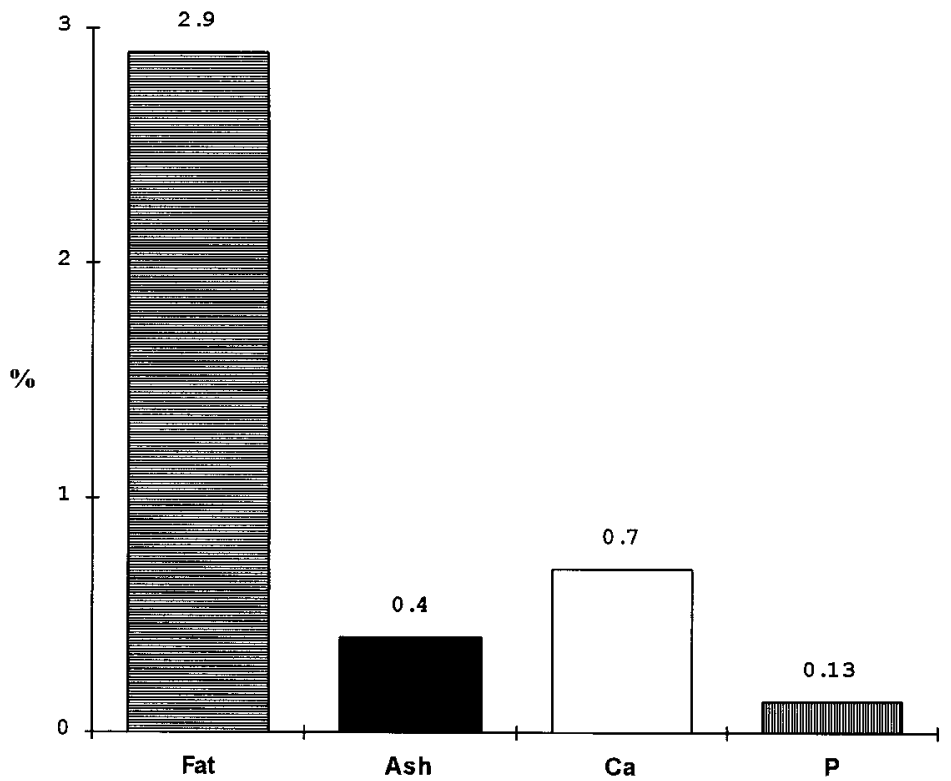

Fig. 4. Fat, ash, Ca and $P$ composition of carob (Ceratonia siliqua $L$ ) seeds collected from Ajloun forests rangeland.

respectively (Fig. 6). Seed dispersion from sheep terminated after 96 hours of ingestion, whereas goats continued to disperse seeds for a longer period than sheep. The linear, quadratic and cubic polynomial regression models for seed germination dispersed from goat were highly significant with $\mathrm{R}^{2}$ values of $0.86,0.87$, and 0.93 , respectively, and for those dispersed by sheep the $\mathrm{R}^{2}$ values were $0.72,0.72$, and 0.91 , respectively (Table 1 ).

\section{Discussion}

Jordan has a unimodal precipitation pattern, with a short rainy period followed by an extended dry period with limited opportunities for herbaceous forage production. Plant dormancy accelerates a decline in both quantity and quality of forage. Annual grasses may lose $75 \%$ of their protein content and up to $52 \%$ of their phosphorous during the dry season (Louis et al. 1983). Wheat and barley stubble grazing starts immediatly after harvesting in June and lasts until September, providing the basic diet for sheep throughout the summer into autumn when supplementary feeding starts (ACSAD 1983). The feeding value of the grass residue deteriorates after a month of harvesting and the animals begin losing weight. Supplementation with cotton seed meal or cereal grain at a rate of $100 \mathrm{~g} \mathrm{day}^{-1}$ could stop the weight losses (Turminini 1991). The amount of subsidized feed stuff is estimated around 444 thousand tons (FAO 1994). In autumn, sheep flocks depend on the remaining stubble and native pasture. Ceratonia siliqua L. is a native fodder tree found in many regions of the Middle East including Jordan. It is a valuable feed supplement during dry seasons and emergencies. Pods of Ceratonia siliqua have considerable feed potential in the semiarid and subhumid rangelands of Jordan.

Livestock usually require feed supplementation for 6 months in a normal year and 9 months during particularly dry years (Nesheiwat and Muhammed 1987). Protein contents of carob pods and seeds are high (16.7 and 6.8\%, respectively) and therefore represent a good source of protein for livestock during dry summers and autumns. Carbohydrates were $71 \%$ in the seeds and $80 \%$ in the pods, whereas fiber contents of pods $(9.2 \%)$ and seeds $(11.5 \%)$ were low indicating their importance as a highly quality source of fodder. Energy and protein are the most limiting nutrients to range livestock production (Holechek and Herbel 1986). El-Shatnawi and 


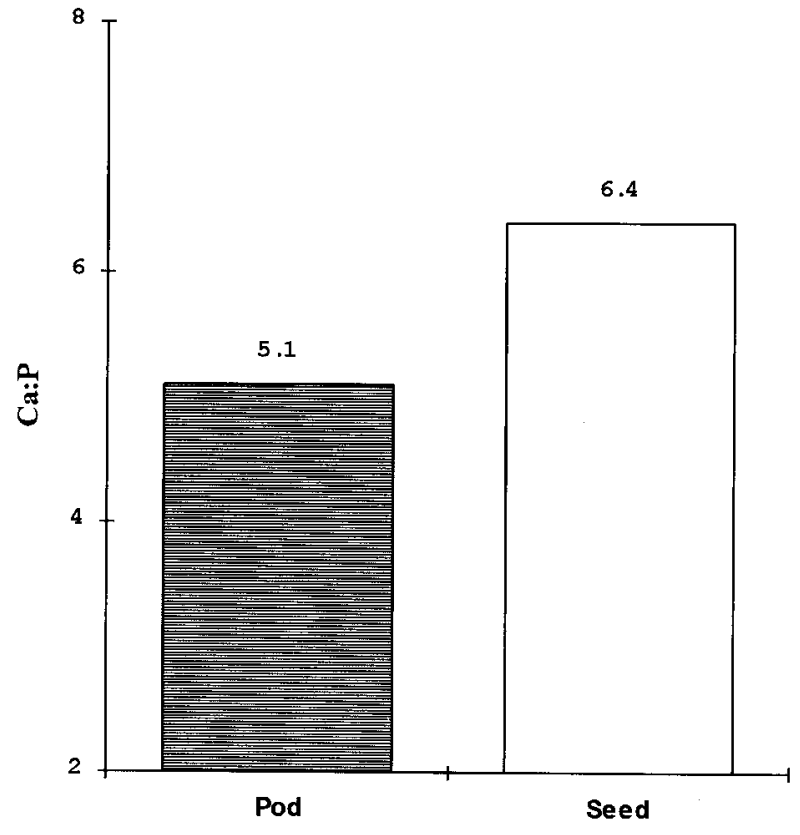

Fig. 5. Calicum:Phosphorous ratio in carob (Ceratonia siliqua $\mathrm{L}$ ) seeds and pods collected from Ajloun forests rangeland.

Mohawesh (2000) reported the importance of the woody plants as a feed supplement for livestock during summer and autumn seasons in the semiarid grasslands of Jordan. Our results showed that crude protein and carbohydrates contents in carob pods and seeds were sufficient to meet the maintenance and lactation requirements of ewes throughout the year. Ewes require 7 to $9 \%$ crude protein for maintenance and 10 to $12 \%$ for lactation. They also need $0.15 \%$ to $0.20 \% \mathrm{P}$ for maintenance and 0.25 to $0.30 \%$ for lactation (Holechek et al. 1998). Therefore, introducing carob fruits into livetock feeds will improve the nutritive value of their food and may minimize the need for grain supplement during summer and autumn.
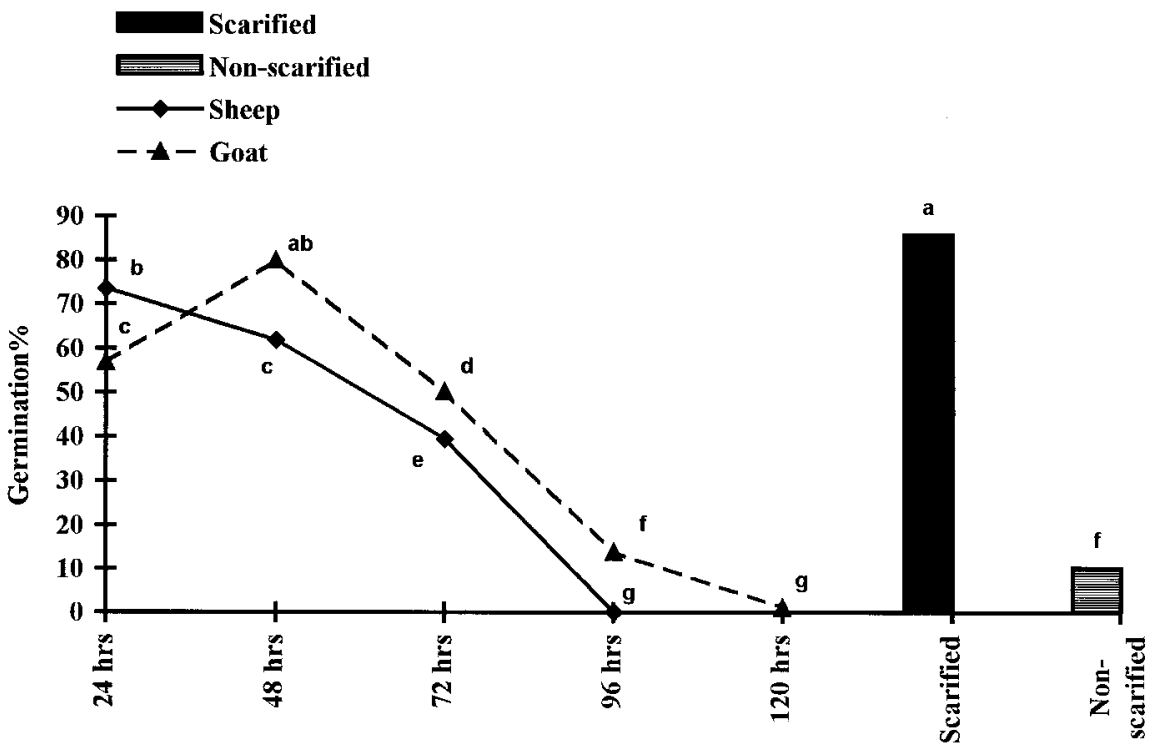

Seed treatment

Fig. 6. Germination \% of scarified, non-scarified and dispersed carob (Ceratonia siliqua L) seeds from Awasi sheep and Baladi goat after 24, 48, 72, 96, and 120 hours. Values with different letters differ significantly according to LSD at $\mathbf{P}<0.01$.
Carob seeds contain higher amounts of protein, fiber, fat and $\mathrm{Ca}$, than pods, whereas deseeded pods contained higher carbohydrates and $\mathrm{P}$ than seeds. Protein content was higher than previously reported in Greece (Marakis et al. 1987), Spain (Calixto and Canellas 1982), Portugal (Amaral-Collaco et al. 1987), Cyprus (Orphanos and Papaconstantinou 1969) and California (Coit 1967). The crude fat content was similar to those reported by Calixto and Canellas (1982) in Spanish carob. Fiber content of Jordanian carob was lower than the values reported by Amaral-Collaco et al. (1987) and Marakis (1996).

The results indicate that the hard seedcoat dormancy prevails in carob seeds. Hence, scarification increased germination from $10 \%$ to $85 \%$ (Fig. 6). The strongest relationships between seed germination and the length of incubation period in the digestive system of sheep and goat are cubic (Table 1). Maximum germination percentages were obtained when seeds were incubated for $24(74 \%)$ and 48 hours $(80 \%)$ in the digestive systems of sheep and goat, respectively. However, germination declined as the incubation period increased. Results agree with data reported by Fredrickson et al. (1997) who found longer seed incubation periods to reduce seed germination. Seed dispersal from sheep continued for only 4 days, whereas goat dispersed seeds for a longer period. The amount of dispersed seed decreased progressively with time for both livestock types. Germination of the seeds that were dispersed by goats after 48 hours was the highest. Seeds passing through the rumen quickly may not be scarified and therfore have a low germinability, but when scarified in the rumen for extended period may be detrimental to seed viability (Archer and Pyke 1991). Goats, as browsers, consume lower amounts of roughage compared with more concentrated feeds. Hofmann (1989) and Wallander et al. (1995) observed a negative relationship between roughage consumption and the amount of seed that passes with manure. This explains ability for less rumination and more viable seed passages in comparison with sheep. Carob provides nutritious pods that have smooth seeds with extremely hard coat which evade or resist strong molars. The seeds of many forest trees are adapted to passage through the digestive tracts of animals without being severely harmed. However, digestive juices may weaken the seed coat, and thus favor water absorption and eventually, germination (Barnes et al. 1998). 
Table 1. Coefficient of determinations (R2), $F$ values and regression coefficients for linear, quadratic, and cubic models for carob seeds germination \% dispersed from sheep and goat.

\begin{tabular}{lccccccc}
\hline \hline & \multicolumn{3}{c}{ Goat } & & \multicolumn{3}{c}{ Sheep } \\
\cline { 2 - 3 } \cline { 6 - 7 } & Linear & Quadratic & Cubic & & Linear & Quadratic & Cubic \\
\hline $\mathrm{R}^{2}$ & 0.864 & 0.874 & 0.9320 & & 0.718 & 0.7230 & 0.9140 \\
$\mathrm{~F}$ & 369.800 & 198.500 & 255.6000 & & 147.970 & 73.2600 & 197.6310 \\
$\mathrm{~b}_{0}$ & 81.291 & 91.245 & 42.6590 & & 87.267 & 91.9150 & -15.0190 \\
$\mathrm{~b}_{1}$ & -0.607 & -0.912 & 1.5930 & & -0.663 & -0.8050 & 4.7060 \\
$\mathrm{~b}_{2}$ & & 0.002 & -0.0320 & & 0.0008 & -0.0740 \\
$\mathrm{~b}_{3}$ & & 0.0001 & & & 0.003 \\
\hline
\end{tabular}

Carob fruits have a sweet taste; livestock may prefer them to other forest fruits. This would facilitate seed dispersal by sheep and goat. Results of this experiment confirm previous finding of Thill et al. (1986), that seeds consumed by animals are either destroyed by mastication and digestion or dispersed to new sites. Sheep and goat are very important dispersal agents for carob seeds and thus, instrumental in maintaining and spreading carob tree populations. Brown and Archer (1987) reported the effectiveness of livestock in dispersing hard-seeded legumes. Our results indicate mutalism relationships between carob trees and sheep and goat.

\section{Conclusion}

Carob trees provide shelter and nutritious fruit for livestock. Its pods and seeds are a good source for protein, carbohydrates, and fiber. Both pods and seeds contain enough crude protein and energy to meet the maintenance and lactation requirements of ewes. Livestock break the seed-coat dormancy and disperse seed to new sites. However, goats may be more efficient transporters of carob seeds because of their ability to disperse viable carob seeds over a longer period.

\section{Literature Cited}

ACSAD. 1983. Studies of Houd-Al Hamad. Animal production in the Jordanian Hamad ACSAD-Damascus (in Arabic).

Amaral-Collaco, M.T., J. I. Roseiro, G.A.. Avlino and H. Teixera. 1987. The quality of sugar content of two Portuguese carob varieties-Their influence on the technological transformation, p.11-18. In: P. Fito and A Mulet (eds), Proc. of $2^{\text {nd }}$ International Carob Symposium, Valencia, Spain (29 Sept-1Oct).

Anon. 1997. The Annual Report of Agricultural Statistics. Ministry of Agr., Amman, Jordan.
Anon. 1998. Jordan Country Study on Biological Diversity. The General Cooperation for the Environ.Protection. Amman, Jordan

AOAC. 1984. Official Methods of Analysis. Assoc. of Official Analytical Chemists. Washington, DC.

Archer, S. and D. Pyke. 1991. Plant-animal interactions affecting plant establishment and Range Manage. 44:558-565.

Barnes, B.V., D.R. Zak, S.R. Denton and S.H. Spurr. 1998. Forest Ecology. John Wiley \& Sons, Inc. New York.

Brito de Carvalho, J.H. 1987. Criteria for evaluation of carob varieties, p. 174-181. In: P. Fito and A. Mulet (eds), Proc. of $2^{\text {nd }}$ Internat. Carob Symp., Valencia, Spain (29 Sept-1Oct).

Brown, J. R. and S. Archer. 1987. Woody plant seed dispersal and gap formation in a North American subtropical savanna woodland: The role of domestic herbivores. Vegetatio 73:73--80.

Calixto, F.S. and J. Canellas. 1982. Components of nutritional interest in carob pods (Ceratonia siliqua L.). J. Food Sci. Agr. 33:1319-1323.

Coit, J.E. 1967. Carob varieties for the semiDigest 21:5-9.

Gaitis, F., S. Marakis and S. Diamantoglou. 1994. Carob varieties from Greek Island Lefkada. In: S. K. Manolis (ed.), Proc. of the $16^{\text {th }}$ Congress of Hellenic Soc. of Biol. Sci., Volos, Greece 5-7 May.

El-Shatnawi, M.J. and Y. Mohawesh. 2000. Seasonal chemical composition of saltbush in semiarid grasslands of Jordan. J. Range Manage. 53:211-214.

FAO. 1994. Sheep production under extensive systems in the Near East: Jordan pastoral system a case study. Near East Regional Office, Food and Agr. Organ. of the United Nations.

Fredrickson, E.L., R.E. Estell, K.E. Havestad, T. Kisksi, J.V. Toll, M.D. Remmenga. 1997. Effects of ruminant digestion on germination of lehmann lovegrass seed. J. Range Manage. 50:20-26.

Hofmann, R. R. 1989. Evolutionary steps of ecophysiological adaptation and diversification of ruminants: a comparative view of their digestive system. Oecologia 78:443-457. persistence on revegetated rangeland. J. arid southwest. Fruit Varieties and Hort.
Holechek, J.L., and C.H. Herbel. 1986. Supplementing range livestock. Rangelands 8:29-33.

Holechek, J.L., R.D. Pieper and C.H. Herbel. 1998. Range Management Principles and Practices. Prentice Hall, Englewood Cliffs, N.J.

Janzen, D. H. 1983. Dispersal of seeds by vertebrate guts In: D.J. Futuyma and M. Slatkin (eds.), Coevolution. Sinauer Association, Sunderland, Maine.

Louis, S.L., A. Dankintafo, B. Bookary, and N. Goumey. 1983. Seasonal influence on the nutritive value of the rangeland in Niger pastoral zone. Ministry of Rural Development US AID Tech. Bull. 2. Tahoua, Niger.

Marakis, S . 1980. New fungal strains for microbial protein production from carob beans. Unpublished Ph.D. Diss. University of Athens, Greece.

Marakis, S. 1996. Carob beans in food: Current status and future potentials-A critical appraisal. J. Food Sci. Tech. 33:365-383.

Marakis, S., J. Kalaitzakis, and K. Mitrakos. 1987. Criteria for recognizing carob tree varieties, p. 43-49. In: P. Fito and A. Mulet (eds), Proc. of $2^{\text {nd }}$ International Carob Symposium, Valencia, Spain (29 Sept-1Oct).

Marakis, S., M. Lambrakis, and S. Diamantoglou. 1993. Tannin chemistry of nine Cretan carob verities. Chimica Chronica, New Series 22:213-224.

Nesheiwat, K and J. Muhammed. 1987. Socio-economy and farming systems. Vol. 2 of the base-line study of Ma'in Pilot Project Perimeter. Amman-Jordan. MOA/FAO.

Neter J, W. Wasserman and M.H. Kutner. 1989. Applied Linear Regression Models. Richard D. IRWIN, INC. Boston, Mass., USA.

Orphanos, P. I. and J. Papaconstantinou. 1969. The Carob varieties of Cyprus.Cyprus Agr. Res. Inst. Tech. Bull. 5:1-13.

Steel, G. D. and J.H. Torrie. 1980. Principles and Procedures of Statistics: A Biometrical Approach. McGraw-Hill Inc. New York, N.Y

Thill, D. C., D.L. Zamora and D.L. Kambitsch. 1986. The germination and viability of excreted common crupina (Crupina vulgaris) achenes. Weed Sci. 34:237-241.

Turminini, A. 1991. By-products of crops and straw and formulation of rations. Range, feeds and animal production program. ICARDA, Aleppo.

Wallander, R. T., B.E. Olson and J.R. Lacey. 1995. Spotted knapweed seed viability after passing through sheep and mule deer. J. Range Manage. 48:145-149.

Watanabe, F.S. and S. Olsen. 1965. Test of an ascorbic acid method for determining phosphorus in water and $\mathrm{NaHCO}_{3}$ extracts from soil. Soil Sci. Soc. Amer. Proc. 21:677-678.

Wursch, P. 1987. Structure of tannins in carob pod and their antidiarrhoeic properties, $\mathrm{p}$. 93-97. In: P. Fito and A. Mulet (eds.), Proc. of $2^{\text {nd }}$ Internat. Carob Symposium. CabanasTavira, Portugal, May 19-23. 


\title{
Adaptation of perennial triticeae to the eastern Central Great Plains
}

\author{
KENNETH P. VOGEL* AND KEVIN J. JENSEN
}

Authors are Research Geneticist, USDA-ARS, 344 Keim Hall, University of Nebraska, P.O. Box 830937, Lincoln, Nebraska 58583-0937 and Research Geneticist, USDA-ARS, Forage and Range Research Laboratory, Utah State University, Logan, Utah 84322-6300. *Corresponding author, kpv@unlserve.unl.edu.

\begin{abstract}
The tribe Triticeae contains over 250 perennial species that are components of grasslands in the temperate and sub-arctic regions of the world and includes some of the world's most valuable forage and rangeland species. Many of these species had not been evaluated previously in the Central Great Plains, USA. A subset of the germplasm of the tribe Triticeae which included over 100 accessions of 55 different species was evaluated in a replicated, space-planted trial in eastern Nebraska during 1994-1996 to determine the survival and forage productivity of the accessions. The evaluated accessions were representative of perennial Triticeae genera and genomes. Perennial grasses of the Triticeae are based on the P, St, H, Ns, E, W, Y genomes and an unknown Xm genome(s). Triticeae that survived and had acceptable forage yields during the period of the trial were the Agropyron's - crested wheatgrasses ( PP and PPPP genomes), Psathyrostachys- Russian wildryes (NsNs genomes), Thinopyron's-intermediate and tall wheatgrasses (EEEEStSt and EEEEEEStSt genomes), some Elymus (StStHH genomes), several Leymus (NsNsXmXm genomes), and Pascopyrum-western wheatgrass (StStHHNsNsXmXm genomes). Several Leymus species had not been evaluated previously in this region but showed considerable potential and merit additional evaluation, including $L$. chinensis, $L$. akmolinensi, L. racemosus, L. sabulosus, and L. secalinus. Species with only the $\mathrm{H}$ genome (Hordeum) and $\mathrm{St}$ genome (Pseudoroegneria) were not adapted to the region because of poor survival or low productivity. The study provides an example of how the rapidly emerging field of genomics can have practical applications to grasslands and rangelands.
\end{abstract}

Key Words: Triticeae, Agropyron, Thinopyrum, Elymus, Leymus, Pascopyrum, survival, forage yield

The tribe Triticeae contains over 250 cool-season, perennial species that are components of grasslands in the temperate and sub-arctic regions of the world. Some Triticeae species such as the crested (Agropyron species) and intermediate wheatgrasses (Thinopyrum sp.) are important species for revegetating grasslands and retired cropland in the Central Great Plains. There is an increasing demand for improved cool-season or $\mathrm{C}_{3}$ grasses to provide high quality forage to livestock during spring, fall, and early winter in integrated livestock production systems in the central Great Plains. In this region rangelands, which are composed

Journal Series No. 12175 , Nebraska Agr. Exp. Sta..

Manuscrpt accepted 15 Jan. 2001.

\section{Resumen}

La tribu Triticeae contiene más de 250 especies perennes que son componentes de los pastizales de las regiones templadas y subárticas del mundo e incluyen algunas de las especies forrajeras más valiosas del mundo. Muchas de estas especies no se han evaluadas previamente en las Grandes Planicies Centrales de Estados Unidos. Un subgrupo de germoplasma de la tribu Triticeae, el cual incluyó mas de 100 entradas de 55 especies diferentes, se evaluó en un ensayo repetido en espacio en el este de Nebraska durante 1994 a 1996 para determinar la sobrevivencia y productividad de las entradas evaluadas. Las entradas evaluadas fueron representativas de generos perennes Triticeae y genomas. Los zacates perennes de la tribu Triticeae están basados en los genomas $\mathrm{P}, \mathrm{St}, \mathrm{H}, \mathrm{Ns}, \mathrm{E}, \mathrm{W}, \mathrm{Y}$ y en un genoma(s) desconocido $\mathrm{Xm}$. Los Triticeae que sobrevivieron y tuvieron rendimientos de forraje aceptables durante el período del ensayo fueron: los Agropyron's - "Crested wheatgrasses" (genomas PP y PPPP), Psathyrostachys - "Russian wildryes" (genomas NsNs), Thinopyron's- "Intermediate" and "Tall wheatgrasses" (genomas EEEEStSt y EEEEEEStSt), algunos Elymus (genomas StStHH ), varios Leymus (genomas NsNsXmXm ) y Pascopyrum - "Western wheatgrass" (genomas StStHHNsNsXmXm). Varias especies de Leymus no habían sido previamente evaluadas en esta región, pero mostraron un considerable potencial y merecen una evaluación adicional, incluyendo $L$. chinensis, $L$. akmolinensi, L. racemosus, L. sabulosus y L. secalinus. Especies con solo el genoma H (Hordeum) y el genoma St (Pseudoroegneria) no se adaptaron a la región debido a su pobre sobrevivencia y baja productividad. Este estudio provee un ejemplo de cómo el emergente campo de genómicos puede tener aplicaciones prácticas en los zacatales y pastizales.

primarily of warm-season $\left(\mathrm{C}_{4}\right)$ grasses or seeded warm-season pastures, are used for summer grazing.

In the last 25 years, several germplasm collection expeditions have been made in eastern Europe and Asia to collect grass germplasm, particularly of the Tribe Triticeae. Many of the collections were made in areas which were previously not open for collection. Extensive germplasm collections of Triticeae species currently are available for evaluation. Except for many of the Thinopyrum accessions (primarily intermediate wheatgrasses, $T$. intermedium, and tall wheatgrasses, $T$. ponticum) and some crested wheatgrasses (Agropyron spp) most of these accessions have not been previously evaluated in the Central Great Plains.

The objective of this study was to evaluate species of the perennial Triticeae that may have potential for use in grassland agriculture in the central Great Plains of the USA and to identify specif- 
ic genomes within the Triticeae grasses that are critical for survival and forage productivity in the eastern part of the Central Great Plains.

Previous research summarized by Dewey (1984), Wang et al. (1994), and Asay and Jensen (1996a, 1996b) and others has demonstrated that perennial grasses of the tribe Triticeae are comprised of the genomes P, St, H, Ns, E, W, Y and an $\mathrm{Xm}$ genome of unknown orgin. The cytogenetic definition of genome, i.e, the haploid set of chromosomes of a diploid species (Shultz-Shaffer 1980) will be used in this report. The classification of the Triticeae has been and remains a matter of controversy (Barkworth 1992, Kellogg 1994). For this paper, the genomic classification, which groups species according to genome content (Dewey 1984, Barkworth and Dewey 1985) will be used with the following exceptions. Under the current GRIN classification system, Tzvelev's (1984) treatment of the Triticeae that lumps the genus Thinopyrum and Pseudoroegneria into the enlarged Elytrigia is used. We will follow Dewey's (1984) treatment that recognizes both Thinopyrum and Pseudoroegneria as separate genera. Dewey (1984) indicated that Leymus species and Pascopyrum contain the $\mathrm{J}(=\mathrm{E})$ genome. Subsequent reports (Zhang and Dvorak 1991, Wang and Jensen, 1994) based on molecular genetic and cytogenetic analysis indicate that the $\mathrm{J}$ genome does not occur in Leymus or Pascopyrum. Asay and Jensen (1996a, 1996b) have designated the unknown genome in Leymus and Pascopyrum the Xm or unknown genome following the genome nomenclature system for the Triticeae proposed by Wang et al. (1994). Species classified as Critesion by Barkworth and Dewey (1985) are listed as Hordeum in this report. To simplify reporting, genus and species names with associated authorities of the plant material used in this study are listed in Table 1 along with common names of some of the more widely used grasses.

\section{Materials and Methods}

Grasses used in this study (Table 1) were primarily plant introductions obtained from the U.S. Department of Agriculture's National Plant Germplasm System via the USDA-ARS Forage and Range Research Laboratory at Utah State University, Logan, Ut. where they were identified. These accessions have a PI (for plant introduction) numerical designation and can be obtained from the USDA Plant Germplasm System. The other accessions used in this study are experimental breeding lines maintained by USDA-ARS Laboratory at Logan, Ut. or were released cultivars (designated cv.) obtained by the USDA-ARS grass breeding program at Lincoln, Neb. The accessions used in the study (Table 1) were chosen to represent the autoploid and alloploid combinations that exist within the perennial Triticeae. Many of the species were represented by 2 accessions originating from different areas. Seeds of the genus Australopyrum which are comprised of the $\mathrm{W}$ genome were not available for use in this study. Chromosome numbers of these accessions were determined by the USDA-ARS Forage and Range Laboratory at Logan, Ut. using conventional chromosome counts or at Lincoln, Neb. where they were estimated by flow cytometry estimates of cellular DNA content (Vogel et al. 1999). The genomic constituents of the species are based on previously summarized or reported research by Dewey (1984), Barkworth and Dewey (1985), Zhang and Dvorak (1991), Liu and Wang (1993), Wang and Jensen (1994), Wang et al. (1994), Asay and Jensen (1996a, 1996b), Zhang and Wang (1996), and Zhang et al. (1996).

Seed of these grasses was planted on 23 March 1994 in a greenhouse at Lincoln, Neb. Prior to seeding, seed was wetchilled for 2 weeks at $4.5^{\circ} \mathrm{C}$ to break dormancy. The seeds were planted in supercell cone-tainers or mini-pots $(22 \mathrm{~cm}$ deep, $4 \mathrm{~cm}$ diam.) which contained a mixture of $2: 1: 1$ soil/peat/vermiculite and were thinned to 1 per cone-tainer after emergence. Natural light was used and the greenhouse was maintained at a temperature range of 21 to $27^{\circ} \mathrm{C}$. Seedlings were transplanted into a field nursery the first week of July 1994. The field evaluation nursery was located at the Univ. of Nebraska Agricultural Research and Development Center, Mead, Neb. (41 ${ }^{\circ} 4^{\prime}$ $\mathrm{N}, 96^{\circ} 5^{\prime} \mathrm{W}$ ) which is located about $35 \mathrm{~km}$ west of Omaha, Neb. The soil type was Sharpsburg silty clay loam (silty clay Typic Argiudoll). Plots were single rows of space-transplanted plants on $1.1 \mathrm{~m}$ centers. Previous research evaluating Agropyron, Thinopyrum, and Bromus perennial grass germplasm accessions in the central Great Plains demonstrated that a small number of replicates harvested for more than 1 year provided adequate statistical precision (Lamb et al. 1984, Vogel 1980, 1983, Vogel et al. 1986). The experimental design was a randomized complete block with 2 replicates. Accessions were blocked by genus. Genera, and species and accessions within a genus were randomized within each replicate.

Hand weeding and herbicides were used for weed control. Since some of the species are highly rhizomatous, periodic roto-tilling with a heavy duty roto-tiller was used to keep plants cut back to an area of $0.2 \mathrm{~m}^{2}$. The herbicides metolachlor [2chloro-N-(2-ethyl-6-methyl-phenyl)-N(2-methoxy-1-methylethyl)acetamide] and imazethapyr \{2-[4,5-dihydro-4methyl-4-(1-methylethyl)-5-oxo-1H-imidazol-2-yl]-5-ethyl-3-pyridinecarboxylic acid \} were applied 2 weeks prior to transplanting and in May of 1995 and 1996 at rates of $2 \mathrm{~kg} \mathrm{ha}^{-1}$ and $0.03 \mathrm{~kg} \mathrm{ha}^{-1}$, respectively. The herbicide 2,4-D (2,4dichlorophenoxyacetic acid) was applied in July of 1994 and May of 1996 for broadleaf weed control. Nitrogen fertilizer was not applied the establishment year. In 1995 and 1996, $112 \mathrm{~kg} \mathrm{~N}^{-1}\left(\mathrm{NH}_{4} \mathrm{NO}_{3}\right)$ was applied the last week of April. No other fertilizers were used.

Plots were harvested after flowering with a flail type plot harvester on 15 August 1995 and 11 July 1996 at a height of approximately $10 \mathrm{~cm}$. Harvest was delayed in 1995 because of our unfamiliarity with the plant material. Some accessions produced only limited seed heads and it was difficult to initially ascertain when flowering had occurred. A subsample from each plot was dried in a forced draft oven at $50^{\circ} \mathrm{C}$ to determine dry matter concentration of the harvested forage, which was used to convert fresh weight yields to a dry weight basis. Because some plants did not survive the establishment year or post-establishment years, yields were expressed on a single-plant basis by dividing plot dry weight by the number of plants harvested per plot each year. Number of plants harvested was determined at the time of harvest. Forage yields are expressed as grams/plant on a dry weight basis. Survival percentage was determined as the percentage of plants surviving at the time of the final forage harvest in 1996. A plant was scored as surviving if any green leaf tissue was present.

Analysis of variance procedures were used to assess the statistical significance of variation among genera and accessions within genera using plot means over years (Snedecor and Cochran 1989). The error variances for genera and accessions nested within genera was used to calculate LSD values for each trait where the $F$ tests for genera or accessions were significant at 
Table 1. Mean forage yields and survival percentages for perennial Triticeae species grown at Mead, Nebraska, 1994 to 1996.

\begin{tabular}{|c|c|c|c|c|c|c|}
\hline Species & Genome $^{1}$ & $2 n^{2}$ & $\begin{array}{l}\text { Accession } \\
\text { or } \operatorname{strain}^{3}\end{array}$ & $\begin{array}{l}\text { Forage } \\
\text { yield }\end{array}$ & Survival & Origin $^{4}$ \\
\hline & & & & (g/plant) & $(\%)$ & \\
\hline \multicolumn{7}{|l|}{ Agropyron Gaertner } \\
\hline A. cristatum & PP & 14 & PI 314600 & 68 & 100 & USSR \\
\hline A. cristatum & PP & 14 & cv Ruff & 233 & 100 & USSR \\
\hline A. mongolicum Keng & PP & 14 & PI 406450 & 92 & 100 & USSR \\
\hline A. mongolicum & PP & 14 & PI 499391 & 58 & 100 & PRC \\
\hline A. desertorum & PPPP & 28 & cv Nordan & 208 & 100 & USSR \\
\hline A. desertorum & PPPP & 28 & PI 314057 & 188 & 100 & USSR \\
\hline & \multicolumn{5}{|c|}{ Pseudoroegneria (Nevski) À. Löve } & USSR \\
\hline P. strigosa (M. Bieb) & StSt & 14 & D3778 & 9 & 80 & PRC \\
\hline P. spicata & StSt & 14 & PI 232134 & 15 & 82 & USA \\
\hline P. stipifolia (Czern ex Nevski) & StSt & 14 & PI 440000 & 35 & 89 & USSR \\
\hline P. geniculata (Trin.) À. Löve & StStStSt & 28 & DJ3875 & 9 & 100 & USSR \\
\hline \multicolumn{7}{|l|}{ Hordeum L. } \\
\hline H. bogdanii Wilensky & $\mathrm{HH}$ & 14 & PI 269406 & 44 & 22 & Afganistan \\
\hline Afganistan $H$. bogdanii & $\mathrm{HH}$ & 14 & PI 440413 & 49 & 19 & USSR \\
\hline H. brachyantherum Nevski & $\mathrm{HH}$ & 14 & D3571 & $38^{6}$ & $0^{6}$ & USA \\
\hline $\begin{array}{l}\text { H. brevisubulatum subsp. violaceum } \\
\text { (Boise \& Hofenacker) Tzvelev }\end{array}$ & $\mathrm{HH}$ & 14 & PI 401374 & 31 & 83 & Iran \\
\hline H. brevisubulatum subsp. violaceum & $\mathrm{HH}$ & 14 & PI 531774 & 68 & 83 & USSR \\
\hline H. bulbosum L. & $\mathrm{HH}$ & 14 & PI 318649 & 4 & 66 & Greece \\
\hline H. bulbosum & HHHH & 28 & PI 343189 & 53 & $0^{6}$ & USSR \\
\hline H. californicum Covas \& Stebbins & $\mathrm{HH}$ & 14 & PI 531778 & 20 & 25 & USA \\
\hline \multicolumn{7}{|l|}{ Psathyrostachys Nevski } \\
\hline P. fragilis (Boise) Nevski & NsNs & 14 & PI 343190 & 42 & 72 & Iran \\
\hline P. fragilis & NsNs & 14 & 343192 & 91 & 100 & Iran \\
\hline P. juncea (Fisher) Nevski [Russian wildrye] & NsNs & 14 & PI 406468 & 142 & 95 & USSR \\
\hline P. juncea & NsNs & 14 & PI 531824 & 116 & 100 & PRC \\
\hline P. stoloniformis C.Baden & NsNs & 14 & D2562 & 33 & 100 & PRC \\
\hline P. stoloniformis & NsNs & 14 & D3376 & 53 & 100 & PRC \\
\hline \multicolumn{3}{|l|}{ Thinopyrum À. Löve } & & 10 & 100 & USSR \\
\hline $\begin{array}{l}\text { T. bessarabicum } \\
\text { T. }\end{array}$ & $E^{b} E^{b}$ & $\begin{array}{l}14 \\
14\end{array}$ & AJC305 & 41 & 88 & USSR \\
\hline T. elongatum (Host) D.R. Dewey & $E^{\mathrm{e}} E^{\mathrm{e}}$ & 14 & D3610 & 18 & 100 & Israel \\
\hline T. junceiforme (Löve \& Löve) Ä Löve & $E^{b} E^{b} E^{e} E^{e}$ & 28 & PI 297873 & 15 & 25 & Portugal \\
\hline T. junceiforme & $E^{b} E^{b} E^{e} E^{e}$ & 28 & D3463 & 66 & 64 & France \\
\hline T. caespitosum Liu \& Wang & EEStSt & 28 & PI 531716 & 56 & 79 & USSR \\
\hline T. caespitosum & EEStSt & 28 & Jasska 4 & 34 & 60 & USSR \\
\hline $\begin{array}{l}\text { T. intermedium (Host) Barkw. \& D.R. Dewey } \\
\text { [intermediate wheatgrass] }\end{array}$ & EEEEStSt & 42 & cv Slate & 362 & 100 & USSR \\
\hline $\begin{array}{l}\text { T. intermedium subsp. barbulatum (Schur) Barkw. \& D.R. } \\
\text { Dewey [pubescent intermediate wheatgrass] }\end{array}$ & EEEEStSt & 42 & cv Manska & 309 & 100 & USSR \\
\hline T. ponticum (Podp.) Barkw. \& D.R. Dewey & $\begin{array}{l}\text { EEEEEE- } \\
\text { StStStSt }\end{array}$ & 70 & cv Platte & 417 & 100 & USSR \\
\hline \multicolumn{7}{|l|}{ Elymus L. } \\
\hline E. abolinii (Drob.) Tzvelev & StStYY & 28 & PI 531554 & 63 & $0^{6}$ & PRC \\
\hline E. abolinii & StStYY & 28 & PI 531555 & 47 & 50 & PRC \\
\hline
\end{tabular}

Continued on page 677 


\begin{tabular}{|c|c|c|c|c|c|c|}
\hline Species & Genome $^{1}$ & $2 n^{2}$ & $\begin{array}{l}\text { Accession } \\
\text { or strain }\end{array}$ & $\begin{array}{l}\text { Forage } \\
\text { yield }\end{array}$ & Survival & Origin $^{4}$ \\
\hline & & & & (g/plant) & $(\%)$ & \\
\hline E. ciliaris (Trin.) Tzvelev & StStYY & 28 & PI 531576 & 60 & 94 & USSR \\
\hline E. canadensis L. [Canada wildrye] & StStHH & 28 & PI 531564 & 154 & 100 & USA \\
\hline E. canadensis & $\mathrm{StStHH}$ & 28 & PI 531565 & 321 & 100 & USA \\
\hline E. caninus L.) L. & StStHH & 28 & PI 253290 & 38 & 65 & Yugoslavia \\
\hline E. caninus & StStHH & 28 & PI 439906 & 31 & 50 & USSR \\
\hline E. glaucus Buckley [blue wildrye] & StStHH & 28 & D3261 & 22 & $0^{6}$ & USA \\
\hline E. glaucus & StStHH & 28 & D3268 & 20 & $0^{6}$ & USA \\
\hline $\begin{array}{l}\text { E. lanceolatus (Schribner \& Smith) Gould } \\
\text { [thickspike wheatgrass] }\end{array}$ & $\mathrm{StStHH}$ & $28^{\mathrm{fc}}$ & D3626 & 109 & 100 & Canada \\
\hline E. lanceolatus & StStHH & 28 & D3627 & 46 & 100 & USA \\
\hline E. mutabilis (Drob.) Tzvelev & StStHH & 28 & PI 499449 & 48 & 67 & PRC \\
\hline E. mutabilis & StStHH & 28 & PI 499589 & 24 & 28 & PRC \\
\hline E. sibiricus $L$. & StStHH & $28^{\mathrm{fc}}$ & PI 499613 & 100 & 67 & PRC \\
\hline E. sibiricus & StStHH & $28^{\mathrm{fc}}$ & PI 499616 & 120 & 100 & PRC \\
\hline $\begin{array}{l}\text { E. trachycaulus (Link) Gould ex Shinners } \\
\text { [slender wheatgrass] }\end{array}$ & StStHH & 28 & PI 232168 & 52 & 100 & USA \\
\hline E. trachycaulus & StStHH & 28 & PI 276711 & 125 & 100 & Hungary \\
\hline E. trachycaulus & StStHH & 28 & PI 315368 & 196 & 100 & USSR \\
\hline E. alatavicus (Drob.) À. Löve & StStYYPP & 42 & PI 499475 & 7 & 44 & PRC \\
\hline E. alatavicus & StStYYPP & 42 & PI 531709 & 19 & 42 & USSR \\
\hline E. batalinii (Krasn.) À. Löve & StStYYPP & $42^{\mathrm{fc}}$ & D3700 & 97 & 69 & USSR \\
\hline E. batalinii & StStYYPP & 42 & DJ4137 & 19 & 93 & USSR \\
\hline E. dahuricus Turez ex Griseb. & StStHHYY & 42 & PI 499592 & 122 & 81 & $\mathrm{PRC}$ \\
\hline E. dahuricus & StStHHYY & 42 & PI499593 & 78 & 81 & PRC \\
\hline \multicolumn{7}{|l|}{ Leymus Hochst. } \\
\hline L. akmolinensis (Drob.) Tzvelev & NsNsXmXm & 28 & PI 440306 & 57 & 100 & USSR \\
\hline L. akmolinensis & NsNsXmXm & 28 & PI 531794 & 161 & 94 & USSR \\
\hline L. ambiguus (Vasey \& Schribn.) D.R. Dewey & NsNsXmXm & $28^{\mathrm{fc}}$ & KJ59 & 28 & 92 & USA \\
\hline L. ambiguus & NsNsXmXm & 28 & PI 531796 & 16 & 100 & USA \\
\hline L. chinensis (Trin.) Tzvelev & NsNsXmXm & 28 & PI 499515 & 273 & 100 & PRC \\
\hline L. chinensis & NsNsXmXm & 28 & PI 499518 & 227 & 100 & PRC \\
\hline L. cinereus (Scribn. \& Merv.) À.. Löve [basin wildrye] & $\begin{array}{l}\text { NsNsNsNs- } \\
\text { XmXmXmXm }\end{array}$ & $56^{\mathrm{fc}}$ & D3706 & 65 & 100 & USA \\
\hline L. cinereus & NsNsNsNs- & $56^{\mathrm{fc}}$ & Magnar & 100 & 100 & Canada \\
\hline L. cinereus & NsNsXmXm & $28^{\mathrm{fc}}$ & KJ51 & 66 & 93 & USA \\
\hline L. coreanus (K.B.Jensen\&R.R.-C. Wang) & NsNsXmXm & & PI 531578 & 58 & 67 & USSR \\
\hline L. flavescens (Scribner \& Smith) Pilger & NsNsXmXm & 28 & Has \& Har & 91 & 100 & USA \\
\hline L. racemosus (Lam.) Tzvelev [mammoth wildrye] & NsNsXmXm & 28 & PI 313965 & 44 & 86 & USSR \\
\hline L. racemosus & NsNsXmXm & 28 & PI 531812 & 416 & 100 & USSR \\
\hline L. cf. racemous & NsNsXmXm & 28 & DJ3801 & 294 & 100 & USSR \\
\hline L. racemosus & NsNsXmXm & 28 & PI 108491 & 290 & 95 & USSR \\
\hline L. cf. ramosus (Trin.) Tzvelev & NsNsXmXm & 28 & PI 499654 & 59 & 100 & PRC \\
\hline L. sabulosus (M. Bieb.) Tzvelev & NsNsXmXm & 28 & PI 531813 & 341 & 100 & USSR \\
\hline L. sabulosus & NsNsXmXm & 28 & PI 531814 & 234 & 100 & USSR \\
\hline L. salinus clone (M.E. Jones) À. Löve & $\begin{array}{l}\text { NsNsNsNs- } \\
\text { XmXmXmXm }\end{array}$ & 56 & PI 531816 & 81 & 100 & USA \\
\hline L. secalinus (Georgi) Tzvelev & NsNsXmXm & 28 & PI 499524 & 226 & 100 & PRC \\
\hline L. secalinus & NsNsXmXm & 28 & PI 499528 & 173 & 95 & PRC \\
\hline L. triticoides (Buckl) Pilger [beardless wheatgrass] & NsNsXmXm & 28 & PI531822 & 170 & 100 & USA \\
\hline L. tritcoides & NsNsXmXm & 28 & D2950 & 162 & 100 & USA \\
\hline L. tritcoides & NsNsXmXm & 28 & Asay M-9 & 125 & 100 & USA \\
\hline L. tritcoides & NsNsXmXm & 28 & cv. Shoshone & 86 & 100 & USA \\
\hline \multicolumn{7}{|l|}{ Pascopyrum À. Löve } \\
\hline P. smithii (Rydb.) À. Löve [western wheatgrass] & $\begin{array}{l}\text { StStHHNsNs- } \\
\text { XmXm. }\end{array}$ & 56 & cv. Flintlock & 247 & 100 & USA \\
\hline P. smithii & $\begin{array}{l}\text { StStHHNsNs- } \\
\mathrm{XmXm}\end{array}$ & 56 & cv Barton & 183 & 100 & USA \\
\hline P. smithii & $\begin{array}{l}\text { StStHHNsNs- } \\
-\mathrm{XmXm}\end{array}$ & 56 & cv. Rodan & 274 & 100 & USA \\
\hline F ratio for accessions & & & & $5.3^{* *}$ & $3.6^{* *}$ & \\
\hline LSD 0.05 & & & & 103 & 34 & \\
\hline
\end{tabular}

${ }_{2}^{1}$ Superscript on genome letters refers to a subset of that genome.

${ }_{3}^{2}$ Ploidy level determined by conventional chromosome counts except where superscript fc indicates ploidy level was estimated by flow cytometry.

${ }_{3} \mathrm{PI}$ numbers are accession numbers of the USDA Plant Germplasm system; other accession/strain numbers are from the USDA Triticeae collection at Logan, Utah (K.Jensen).

${ }^{4}$ PRC $=$ Peoples Republic of China, USSR = area occupied by former Soviet Union, USA = United States of America followed by postal abbreviation of indivual states. See Germplasm Information Network (GRIN) at http://www/ars-grin.gov/ for specific accession information.

${ }_{6}$ USA common name is in brackets [ ].

${ }^{6}$ Some accessions produced forage yields in 1995 but did not have any surviving plants at the time when final stands were determined in July of 1996 . Yields are means for 1995 and 1996. 
Table 2. Monthly precipitation and average monthly temperatures at Mead, Neb. for the duration of the study and 30 year means for Lincoln and Omaha, Nebr.

\begin{tabular}{|c|c|c|c|c|c|c|c|c|c|c|c|c|c|}
\hline Year/ location & Jan. & Feb. & Mar. & Apr. & May & Jun. & Jul. & Aug. & Sep. & Oct. & Nov. & Dec. & Annual \\
\hline & $-\ldots$ & $\cdots-$ & -- & $--\cdot-$ & $-\ldots$ & Ionthly & ipitat & $\mathrm{mm})$ & --- & $\ldots$ & $-\ldots$ & $\ldots$ & $\ldots-\ldots$ \\
\hline 1994 & 12 & 6 & 0 & 32 & 36 & 230 & 107 & 43 & 95 & 34 & 62 & 16 & 674 \\
\hline 1995 & 20 & 10 & 62 & 109 & 145 & 33 & 26 & 34 & 63 & 35 & 12 & 9 & 558 \\
\hline 1996 & 130 & 2 & 23 & 82 & 185 & 140 & 37 & 76 & 51 & 17 & 59 & 10 & 694 \\
\hline Omaha & 17 & 20 & 54 & 70 & 111 & 99 & 83 & 82 & 93 & 61 & 34 & 24 & 747 \\
\hline \multirow[t]{2}{*}{ Lincoln } & 14 & 18 & 53 & 70 & 99 & 99 & 81 & 87 & 88 & 54 & 32 & 22 & 717 \\
\hline & - & - - . & - & 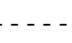 & -- & ge $n$ & tem & ture $(\mathrm{C}$ & - & -- & -- & -- & --- \\
\hline 1994 & -7.2 & -6.7 & 4.7 & 10.1 & 16.9 & 22.4 & 21.7 & 21.6 & 18.3 & 12.6 & 5.1 & -2.6 & 9.7 \\
\hline 1995 & -6.1 & -0.4 & 3.0 & 7.7 & 13.0 & 21.2 & 24.9 & 25.6 & 17 & 11.5 & 0.5 & -2.2 & 9.6 \\
\hline 1996 & -7.8 & -2.7 & -0.6 & 8.5 & 14.3 & 22.1 & 22.2 & 21.6 & 16.4 & 11.9 & -0.4 & -5.9 & 8.3 \\
\hline Omaha & -6.3 & -3.4 & 3.1 & 10.8 & 16.9 & 22.1 & 24.7 & 23.3 & 18.2 & 12.0 & 3.7 & -4.2 & 10.3 \\
\hline Lincoln & -5.9 & -3.0 & -1.9 & 10.9 & 16.7 & 22.4 & 25.6 & 213.8 & 18.5 & 12.0 & 3.8 & -3.6 & 10.4 \\
\hline
\end{tabular}

Data from National Climatic Data Center at http://www.ncdc.noaa/gov.

the 0.05 probability level. Means over years were used because average performance of a perennial over years is the most important indicator of agronomic value, and in previous perennial grass germplasm evaluation research, accession by year interaction effects were either not significant or small (Lamb et al. 1984, Vogel, 1983, Vogel et al. 1986).

\section{Results and Discussion}

In the central Great Plains, the most important trait for a perennial grass is the ability to survive. The temperature of the region can vary from $40^{\circ} \mathrm{C}$ during the summer months to $-40^{\circ} \mathrm{C}$ during winter, sometimes without snow cover (Lawson et al. 1977). During the late fall, winter, and spring there can be large and rapid changes in temperature. Temperature changes of more than $30^{\circ} \mathrm{C}$ can occur within 48 hours. Climatic conditions during this study were typical for the region (Table 2).

Plots were established with transplanted seedlings instead of by direct seeding because of potential differences in seedling vigor and we wanted to ensure that seedlings became well established during the first growing season. There were visible differences among accessions for seedling growth at the time of transplanting. Consequently, we did not collect any first year data but instead used the first growing season to allow the seedlings to become well established. There were significant differences among genera and accessions for survival (Table 1, 3, and 4). As expected based on their previous use in the region, crested wheatgrasses (Agropyron species, P genome) had 100\% survival. Other genera that had species with excellent survival were Pseudoroegneria (St genome), Psathyrostachys (Ns genome) which includes Russian wildrye ( $P$. juncea), Thinopyrum (E and $\mathrm{E}+\mathrm{St}$ genome) species that have both the $\mathrm{E}$ and St genomes (the intermediate and tall wheatgrasses), some Elymus $(\mathrm{St}+\mathrm{Y}, \mathrm{H}$, or $\mathrm{P}$ genomes) species, and most Leymus (Ns+Xm genomes) species. All of the Pascopyrum (St,H,N, and Xm genomes) accessions had survival percentages of $100 \%$. Hordeum (H genome) species had the lowest average survival percentages and no Hordeum species had $100 \%$ survival $($ mean $=34 \%$; range $=0$ to $86 \%$ ). The Pseudoroegneria species with the best survival were from Eurasia while the Elymus species with the best survival were native North American species such as $E$. canadensis, E. lanceolatus, and E. trachycaulus (Table 1). Eighteen of the 24 Leymus accessions had survival percentages of $100 \%$ and only 1 had a survival percentage less than $90 \%$.

The genera with the highest forage yields were Agropyron, Thinopyrum, Leymus, and Pascopyrum (Table 1 and 4). Some species, including Hordeum taxa, had high forage yields the first year of harvest but did not survive the second year. Check cultivars of Agropyrons, Ruff and Nordan, are well adapted standards for identifying species and genomic combinations that had equivalent forage yields $(>$ $100 \mathrm{~g} /$ plant) and more than $90 \%$ survival.

Table 3. Analysis of variance for plant yield and survival of Triticeae species grown at Mead, Nebr. from 1994 to 1996.

\begin{tabular}{lccc}
\hline \hline Source & df & Mean Squares & \\
\hline & & $\frac{\text { Yield (g/plant) }}{29805}$ & $\underline{\text { Survival (\%) }}$ \\
Replicate & 1 & 80124 & 679 \\
Genus & 7 & 2517 & 13407 \\
Replicate x genus & 7 & 14307 & 686 \\
Entry (genus) & 98 & 2695 & 1091 \\
Error & 98 & $31.8^{* *}$ & 301 \\
F for genus & & $5.3^{* *}$ & $19.5^{* *}$ \\
F for species & & $3.6^{* *}$ \\
\hline
\end{tabular}

"*** Indicate significance at the 0.05 and 0.01 levels of probability respectively.
None of the Pseudoroegneria (St genome) or Hordeum (H genome) species had comparable forage yields or survival percentage. The only Psathyrostachys species (Ns genome) that survived both years of the study was Russian wildrye, ( $P$. juncea). The hexaploid and decaploid Thinopyrum species $T$. intermedium and $T$. ponticum had high forage yields and survivability (Table 1). Other genomic combinations within Thinopyrum were not as well adapted. The only Elymus accessions that had yields and survival percentages equivalent to the 2 crested wheatgrass cultivars belonged to species that had the StStHH genomic configuration. These included Canada wildrye (E. canadensis) which is native to Great Plains grasslands, slender wheatgrass (E. trachycaulus) which is native to some North American grasslands, and E. sibiricus, which is an Eurasian counterpart to Canada wildrye. None of the other Eurasian or North American species with the StStHH genomic configuration were as well adapted based on survival scores and forage yields. Many Leymus species with the NsNsXmXm genomic configuration from Eurasia had excellent survival percentages and high forage yields. Many of these species had not been evaluated previously in the Central Great Plains. 
Table 4. Mean forage yields and survival percentages for perennial Triticeae genera averaged over species grown in a space-planted trail at Mead, Nebr. in 1995 and 1996.

\begin{tabular}{lccc}
\hline \hline Genus & Accessions & Forage yield & Survival \\
\hline & $(\mathrm{n})$ & $(\mathrm{g} / \mathrm{plant})$ & $(\%)$ \\
Agropyron & 10 & 153 & 100 \\
Pseudoroegeneria & 10 & 20 & 80 \\
Hordeum & 17 & 57 & 34 \\
Psathyrostachys & 6 & 80 & 94 \\
Thinopyrum & 10 & 153 & 85 \\
Elymus & 24 & 80 & 68 \\
Leymus & 25 & 154 & 97 \\
Pascopyrum & 3 & 235 & 100 \\
F ratio for genera & & $31.8^{* * *}$ & $19.5^{* *}$ \\
LSD & 0.05 & 118 & 44 \\
\hline
\end{tabular}

** Indicates statistical significance at the 0.01 level of probability.

Pascopyrum is a monotypic genus $(P$. smithii - western wheatgrass) that is native to the prairies and plains of North America. The western wheatgrass accessions that were evaluated were representative of Great Plains germplasm and had high forage yields and excellent survival. 'Barton' western wheatgrass was developed by direct increase of a collection from Barton County, Kan., 'Flintlock' was developed by breeding from collection in Kansas and Nebraska, while Rodan was developed by breeding at Mandan, N.D. (Alderson and Sharp 1993)

The adaptability to the central Great Plains and productivity of some of these species such as the crested, intermediate, tall, and western wheatgrasses and Russian wildrye's was known before their genomic configurations were determined (Asay and Jensen 1996a, 1996b). The results of this study correspond with the previously known adaptation and productivity of these species and their constituent genomes. Western wheatgrass apparently gets its adaptability to the central Great Plains from its Leymus genomes (NsNsXmXm). Most species with the HH, HHHH (Hordeum) and StSt, StStStSt (Pseudoroegneria) genomic configurations do not appear to be adapted to the central Great Plains. Several Leymus species showed considerable potential and merit additional evaluation in the central Great Plains. The promising species and the number of accessions of each in the USDA Germplasm System (in parentheses) include Leymus chinensis (36), L. sabulosus (4), L. akmolinensi (3), L. racemosus (30) and L. secalinus (50). In addition to having high forage yields following anthesis, they also had excellent regrowth which stayed green late into the fall. The leaves of some of these species are relatively coarse and their palatability to livestock will need to be determined. According to Asay and Jensen (1996b) many of the Leymus species are characterized by seed dormancy and poor seedling vigor. These traits also will need to be evaluated. In this study, we evaluated only a few of the available accessions of the most promising species. The accessions of these species that are available in the USDA Germplasm System should be evaluated at several locations in the Central Great Plains to identify the most suitable accessions for use in the region and in breeding programs.

The previous work by geneticists such as Douglas Dewey, which has resulted in the genomic characterization of the Triticeae, enabled this study to be structured so that we could characterize grasses by their constituent genomes rather than geographic origin. It provides an example of how the rapidly emerging field of genomics can have practical applications to grasslands and rangelands.

\section{Literature Cited}

Alderson, J.S. and W.C. Sharp. 1993. Grass varieties of the United States. USDA Agr. Handb. 170. Washington, D.C., U.S. Gov. Print. Off.

Asay, K.H. and J.B. Jensen. 1996a. Wheatgrasses. p. 691-724. In: L.E. Moser, D. Buxton, and M.D.Casler (eds.), Cool-season forage grasses. Agron. Monogr.. ASA, CSSA, SSSA, Madison, Wisc.

Asay, K.H. and J.B. Jensen. 1996b. Wildryes. p. 725-748. In: L.E. Moser, D.Buxton, and M.D.Casler (eds.), Cool-season forage grasses. Agron. Monogr. ASA, CSSA, SSSA, Madison, Wisc.

Barkworth, M..E. 1992. Taxonomy of the Triticeae: a historical perspective. Hereditas 116:1-14.

Barkworth, M.E. and D.R. Dewey. 1985. Genomically based genera in the perennial Triticeae of North America: Identification and membership. Amer. J. Bot. 72:767-776.

Dewey, Douglas R. 1984. The genomic system of classification as a guide to intergeneric hybridization with the perennial triticeae $\mathrm{p}$. 209-279. In: J.P. Gustafson (ed.), Gene Manipulation in Plant Improvement. $16^{\text {th }}$
Stadler Genetics Symp., Columbia Mo. Plenum Press, New York, N.Y.

Kellogg, Elizabeth A. 1994. Systematics of the Triticeae: problems and progress, p.207-214. In: R.R.C. Wang, K.B. Jensen, and C. Jaussi (eds.), Proceedings of the $2^{\text {nd }}$ Internat. Triticeae Symp. June 20-24, 1994; Logan, Ut, USA.

Lamb, J. F. S., K. P. Vogel, and P. E. Reece. 1984. Genotype and genotype $x$ environment interaction effects on forage yield and quality of crested wheatgrass. Crop Sci. 24:559-564.

Lawson, Merlin P., Kenneth F. Dewey, and Ralph E. Neild. 1977. Climatic Atlas of Nebraska. Univ. of Nebraska Press, Lincoln, Neb.

Liu, Z-W. and R.R-C. Wang. 1993. Genome analyses of Elytriga caespitosa, Lopopyrum nodosum, Pseudoroegneria geniculata ssp. scythica, and Thinopyrum intermedium. Genome 36:102-111.

Schultz-Shaffer, Jurgen. 1980. Cytogenetics, Plants, Animals, Humans. Springer-Verlag. New York, N.Y.

Snedecor, G.W. and W.C. Cochran. 1989. Statistical Methods. $8^{\text {th }}$ ed. Iowa State Univ. Press. Ames, Ia.

Tzvelev, N.N. 1984. Tribe 3. Triticeae., p. 196-298. A.A. Blakema, Rotterdam.(English translation of: Tzvelev, N.N. 1976. Zlaki SSSR. Nauka Publishers, Leningrad).

Vogel, K. P. 1980. Evaluation of intermediate wheatgrass for use in a breeding program. USDA/SEA-AR, ARR-NC-4. (USDA research bulletin).

Vogel, K. P. 1983. Evaluation of the bromegrass introductions for forage yield and quality. Nebr. Agr. Exp. Sta. Res. Bull. 300.

Vogel, K.P., K. Arumuganathan, and K.B. Jensen. 1999. Nuclear DNA content of perennial grasses of the Tribe Triticeae. Crop Sci. 39:661-667.

Vogel, K.P., P.E. Reece, and J.F.S. Lamb. 1986. Genotype and genotype $\mathrm{x}$ environment interaction effects for forage yield and digestibility of intermediate wheatgrass. Crop Sci. 26:653-658.

Wang, R.R-C and K.B. Jensen. 1994. Absence of the $\mathrm{J}$ genome in Leymus species (Poaceae:Triticeae): Evidence from DNA hybridization and meiotic pairing. Genome 37:231:235

Wang, R.R-C., R. Von Bothmer, J. Dvorak, G. Fedak, I. Linde-Laursen, and $M$. Muramatsu. 1994. P.29-34. In: R.R-C Wang, K.B. Jensen, C. Jaussi (eds.), Proceedings of the $2^{\text {nd }}$ International Triticeae Symposium. Logan, Ut, USA. June 20-24, 1994.

Zhang, H-B. and J. Dvorak. 1991. The genome origins of tetraploid species of Leymus (Poaceae:Triticeae) inferred for variation in repeated nucleotide sequences. Amer. J. Bot. 78: 871-884.

Zhang, W.-Y and R.R-C. Wang. 1996. Genome constitutions of Thinopyrum species determined by RAPD markers and GISH. Agro. Abs. p. 161-162. ASA/CSSA/SSSA, Madison, Wisc.

Zhang, X., Y. Dong, and R.R.-C. Wang. 1996. Characteristics of genomes and chromosomes in partial amphiploids of the hybrid Triticum aestivum $\mathrm{x}$ Thinopyrum ponticum by in situ hybridization, isozyme analyses, and RAPD. Genome 39: 1062-1071. 


\title{
Mesquite and grass interference with establishing redberry juniper seedlings
}

\author{
W.R. TEAGUE, S.L. DOWHOWER, S.G. WHISENANT AND E. FLORES-ANCIRA
}

Authors are associate professor and research associate, Texas Agricultural Experiment Station, Vernon, Texas 76385, professor and graduate student, Department of Rangeland Ecology and Management, College Station, Texas 77843.

\begin{abstract}
Excessive cover of juniper (Juniperus pinchotii Sudw.) reduces forage production, interferes with livestock management, and diminishes the watershed and wildlife habitat values of rangelands. We studied whether juniper seedlings were differentially suppressed in the presence of different grass species, and to what extent established mesquite (Prosopis glandulosa Torr.) trees facilitated or competed with establishing juniper seedlings. Seedlings growing with any of the grasses (RGR $=0.23$ to 0.43 $\mathrm{cm} \mathrm{cm} \mathrm{cm}^{-1}$ ) grew significantly less than those with no grass competition $\left(R G R=0.72 \mathrm{~cm} \mathrm{~cm}^{-1}\right)(P<0.01)$. Juniper seedlings grew significantly less in the presence of buffalograss (Buchloe dactyloides (Nutt.) Engelm.) $\left(\right.$ RGR $=0.23 \mathrm{~cm} \mathrm{~cm}^{-1}$ than with either sideoats grama (Bouteloua curtipendula (Michx.) Torr.) $($ RGR $=0.43 \mathbf{c m}$ $\left.\mathrm{cm}^{-1}\right)$ or tobosagrass (Hilaria mutica $[$ Buckl.] Benth. $)($ RGR $=$ $\left.0.43 \mathrm{~cm} \mathrm{~cm}^{-1}\right)(P<0.01)$. In contrast, juniper seedlings grew larger under intact canopies of mesquite $\left(R G R=0.99 \mathrm{~cm} \mathrm{~cm}^{-1}\right)$ than in open grassland $\left(R G R=0.65 \mathrm{~cm} \mathrm{~cm}^{-1}\right)(P<0.05)$ due in part to the greater nutrient availability $(P<0.05)$ under mesquite canopies. Juniper growing in sub-canopy positions with mesquite trees removed grew less $\left(R G R=0.84 \mathrm{~cm} \mathrm{~cm}^{-1}\right)$ than those growing under mesquite canopies with root competition $\left(\right.$ RGR $\left.=0.99 \mathrm{~cm} \mathrm{~cm}^{-1}\right)(\mathrm{P}<0.05)$. Juniper growing under intact mesquite canopies but without mesquite root competition, grew no better or worse $\left(\operatorname{RGR}=0.93 \mathrm{~cm} \mathrm{~cm}^{-1}\right)$ than those with mesquite root competition $\left(R G R=0.99 \mathrm{~cm} \mathrm{~cm}^{-1}\right)(P>0.05)$, indicating that mesquite root competition with juniper is probably inconsequential. Since junipers grow mainly in fall, winter and spring when mesquite trees are dormant and leafless, the lack of competition may largely be due to these 2 species using resources at different times of the year. Greater nutrient availability beneath mesquite canopies, reduction of summer temperatures, and temporal separation of resource use clearly benefit juniper seedlings growing in the presence of mesquite. Managing for a vigorous grass component with low densities and cover of mesquite is the best way to limit the rate of invasion by juniper.
\end{abstract}

Key Words: Competition, facilitation, mesquite rangeland, seedling establishment

Funding from the E. Paul and Helen Buck Waggoner Foundation Inc. and the Texas Agricultural Experiment Station is gratefully acknowledged. We thank Keith Owens and Don Robinson for reviewing the manuscript.

Manuscript accepted 29 Dec. 00.

\section{Resumen}

La cubierta excesiva de "Juniper" (Juniperus pinchotii Sudw.) reduce la producción de forraje, interfiere con el manejo del ganado y disminuye el valor del pastizal como cuenca hidrológica y hábitat de fauna silvestre. Estudiamos si las plántulas de “" Juniper" fueron diferencialmente suprimidas en presencia de diferentes especies de zacates y en que magnitud los árboles establecidos de "Mesquite" (Prosopis glandulosa Torr.) facilitaron o compitieron con el establecimiento de plántulas de " Juniper . Las plántulas creciendo con cualquiera de los zacates. Las plántulas creciendo con cualquier zacate $(\mathrm{RGR}=\mathbf{0 . 2 3}$ a 0.43 $\mathrm{cm} \mathrm{cm} \mathrm{cm}^{-1}$ ) crecieron significativamente menos que aquellas sin competencia de zacates $\left(\right.$ RGR $\left.=0.72 \mathrm{~cm} \mathrm{~cm}^{-1}\right)(P<0.01)$. Las plántulas de "Juniper" crecieron significativamente menos en presencia de "Buffalograss" (Buchloe dactyloides (Nutt.) Engelm.) $\left(\right.$ RGR $\left.=0.23 \mathrm{~cm} \mathrm{~cm}^{-1}\right)$ que en presencia de "Sideoats grama" (Bouteloua curtipendula (Michx.) Torr.) $(\mathrm{RGR}=0.43 \mathrm{~cm}$ $\left.\mathrm{cm}^{-1}\right)$ "Tobosagrass" (Hilaria mutica [Buckl.] Benth.) $($ RGR = $\left.0.43 \mathrm{~cm} \mathrm{~cm}^{-1}\right)(\mathrm{P}<0.01)$. En contraste, las plántulas de "Juniper" crecieron más grandes bajo las copas intactas de "Mesquite" $\left(\right.$ RGR $\left.=0.99 \mathrm{~cm} \mathrm{~cm}^{-1}\right)$ que en el pastizal abierto $($ RGR $=0.65 \mathrm{~cm}$ $\left.\mathrm{cm}^{-1}\right)(\mathrm{P}<0.05)$ debido en parte a la mayor disponibilidad de nutrientes $(P<0.05)$ bajo las copas de los “ Mesquite”. Las plántulas de "Juniper" creciendo en posiciones de sub-copa con árboles de "Mesquite" removidos crecieron menos $(\mathrm{RGR}=\mathbf{0 . 8 4}$ $\mathrm{cm} \mathrm{cm} \mathrm{cm}^{-1}$ ) que aquellas creciendo bajo las copas de "Mesquite" con competencia de raíz. $\left(\right.$ RGR $\left.=0.99 \mathrm{~cm} \mathrm{~cm}^{-1}\right)(P<0.05)$. Las plántulas de "Juniper" creciendo bajo copas intactas de "Mesquite" pero sin competencia de raíz ni creció mejor ni peor $\left(\right.$ RGR $\left.=0.93 \mathrm{~cm} \mathrm{~cm}^{-1}\right)$ que aquellas con competencia de raíz del “ Mesquite" ( $R$ GR=0.99 $\left.\mathrm{cm} \mathrm{cm}^{-1}\right)(P>0.05)$, indicando que la competencia de raíz de "Mesquite" con el "Juniper" es probablemente insignificante. Dado que el “Juniper" crece principalmente en otoño, invierno y primavera cuando los árboles de "Mesquite" están dormantes y defoliados, la falta de competencia puede deberse en gran parte a que estas 2 especies utilizan los recursos en diferentes tiempos del año. La mayor disponibilidad de nutrientes bajo las copas de "Mesquite", la reducción de las temperaturas de verano y la separación temporal del uso de recursos beneficia claramente a las plántulas de Juniper" creciendo en presencia de "Mesquite". El manejar para mantener un componente vigoroso de zacate con bajas densidades y cobertura de "Mesquite" es la mejor manera de limitar la tasa de invasión del "Juniper. 
Juniper (Juniperus pinchotii Sudw.) reduces grass productivity, especially on shallow soils by altering the light environment, soil water content, soil nutrient availability, and soil thermal regime (Scifres 1980). In addition, excessive cover of these woody plants interferes with movement and handling of livestock and diminishes watershed and wildlife habitat values of rangelands (Scifres 1980, Dye et al. 1995, Fuhlendorf et al. 1996, Johnson et al. 1999). Competition from neighboring plants does not strongly influence the growth rate of young, established juniper but delays reproductive maturity (McPherson and Wright 1987). However, neighboring plants reduce the growth of juniper seedlings in the establishment phase (Van Auken 1993). For example, Smith et al. (1975) report the suppression of juniper seedlings by blue grama (Bouteloua gracilis (H.B.K) Lag. ex Steud), and Jackson and Van Auken (1997) report that establishing juniper plants survived and grew better at the edge of established woodlands than in adjacent grassland.

Knowledge of the relationship between establishing juniper seedlings and associated species may provide insights to developing management strategies for the control of juniper invasion. This study examines 1) whether juniper seedlings are differentially suppressed by major associated grasses, and 2) to what extent established mesquite (Prosopis glandulosa Torr.) trees facilitate or compete with establishing juniper seedlings.

\section{Methods}

This study was conducted on the Y Experimental Ranch (YER), located $25 \mathrm{~km}$ southwest of Crowell $\left(33^{\circ} 52^{\prime} \mathrm{N}, 100^{\circ} 00^{\prime}\right.$ $\mathrm{W})$ in north central Texas. The climate is continental with an average of 220 frostfree growing days. Mean annual precipitation at Crowell is $617 \mathrm{~mm}$, varying from 260 to $990 \mathrm{~mm}$, with peaks in May and September. Annual mean monthly temperature is $17.4^{\circ} \mathrm{C}$, ranging from $36.4^{\circ} \mathrm{C}$ in July to $-2.3^{\circ} \mathrm{C}$ in January. Elevation is 500 $\mathrm{m}$ at the research site and slope is 1 to $3 \%$.

Mesquite trees dominate the vegetation, providing approximately $50 \%$ cover over the experimental area. Junipers have been invading this site, with plants being up to 2$\mathrm{m}$ tall and providing up to $5 \%$ cover. Dominant herbaceous species include tobosagrass (Hilaria mutica [Buckl.] Benth.), sideoats grama (Bouteloua curtipendula (Michx.) Torr.), Texas wintergrass (Nassella leucotricha (Trin. \& Rupr.) Pohl), buffalograss (Buchloe dactyloides
(Nutt.) Engelm.), annual broomweed (Gutierrezia texanum ((DC.) Torr. \& A. Gray), and western ragweed (Ambrosia psilostachya DC.). Soil is a Tilman clay loam (fine, mixed, thermic Typic Paleustoll).

\section{Grass competition study}

In June 1994, 60 juniper seedlings 15 to $18 \mathrm{~cm}$ tall were located in open grassland of approximately 5 ha where woody plant cover was less than $10 \%$. Twenty seedlings per grass species were located growing in patches of grass dominated by sideoats grama, tobosagrass, or buffalograss. These selected patches were at least $1.5 \mathrm{~m}$ in diameter.

Ten of these juniper seedlings were selected as controls around which all herbaceous vegetation for a radius of 0.75 $\mathrm{m}$ at ground level was cleared with a hoe whilst leaving existing litter in place and minimizing disturbance of the soil surface. These areas were kept free of all plants except the juniper seedlings at the centers by hand removal at least monthly. All seedlings were caged to avoid damage by large mammals. Cages were $0.5-\mathrm{m}$ in diameter and constructed out of wire with mesh-size of $15-\mathrm{cm}$. Basal diameter and plant height were measured initially in June 1994 and final measures were taken in November 1996. Basal diameter (mm) was measured with calipers at ground level, avoiding irregular stem thickening. Height was measured from ground level with a ruler to the nearest $0.5 \mathrm{~cm}$.

Herbaceous cover at the experimental site was estimated visually using $0.05-\mathrm{m}^{2}$ quadrats $(20 \times 25-\mathrm{cm})$ along 8 , thirty meter straight-line transects located at random. A total of 40 quadrats were used in each March, July and November of both 1994 and 1995. Cover of grass species, forbs, litter and bare ground were estimated visually in each quadrat.

\section{Mesquite competition study}

This study was conducted at the same time as, and adjacent, to the grass competition study above. Mesquite cover was approximately $50 \%$. Ten juniper seedlings $15-18 \mathrm{~cm}$ tall with intact soil root cores 8 $\mathrm{cm}$ in diameter and $15 \mathrm{~cm}$ deep were selected and transplanted into each of the following situations:

1. Under mesquite canopies,

2. Under mesquite canopies where the tree had been removed at ground level,

3 . Under mesquite canopies where a 1.0$\mathrm{m}^{2}$ area $50 \mathrm{~cm}$ deep was isolated from root competition, and

4. In open grassland.

Even though juniper seedlings occur naturally under established mesquite trees, it was impossible to find sufficient replications for this study under natural conditions. Transplanting ensured that juniper seedling size, mesquite tree size, and the location of juniper seedlings under the tree canopy were relatively uniform. All transplants were located midway between the tree stem and canopy edge to the north of mature mesquite trees 2.5 to $3 \mathrm{~m}$ tall. All other woody plants under the canopies of these trees were removed at ground level with secateurs immediately before transplanting in June 1994. Seedlings were given 4 liters of water every 2 weeks from June through August 1994 to ensure establishment. Mesquite trees were removed in January 1995 using a chainsaw and the exposed, ground level stumps were painted with diesel oil to prevent regrowth. Root isolation was accomplished by digging an $8 \mathrm{~cm}$ wide trench, $50 \mathrm{~cm}$ deep in a circle with a radius of $564 \mathrm{~mm}\left(=1.0 \mathrm{~m}^{2}\right)$ with a juniper seedling planted in the center. The trench walls were lined with heavy-duty plastic to maintain horizontal isolation. The 7 most vigorous plants in each treatment were measured as replicates. All seedlings were caged to avoid damage as in study 1 . Basal diameter and plant height were measured initially in June 1994 and final measures were taken in November 1996 as per the above study.

Soil temperature was measured on 6 days in June 1996 at 1- and 2.5-cm soil depths in open grassland and under mesquite canopies. In the open grassland measurements were made in the following situations; bare ground, shortgrass (buffalograss), tallgrass (sideoats grama or tobosagrass). Measurements $(n=6)$ were made at 0800, 1000, 1200 and 1500 hours on each day at each of these positions. Soil water was measured monthly with a neutron probe at an adjacent site under mesquite canopies ( 9 access tubes) and in open grassland ( 5 access tubes) at the following depths: 0 to 150,150 to 300,300 to 600,600 to 900 and 900 to $1200 \mathrm{~mm}$.

Soil samples were taken in June 1996 to determine soil fertility differences between the open grassland and under the mesquite canopy positions listed above. In each, 2 random samples were taken at each of the following 4-soil depths: 0 to 150,150 to 300,300 to 600 and 600 to $900 \mathrm{~mm}$. The samples were calcareous and analyses to correct for $\mathrm{CaCO}_{3}$ were performed using the equation:

Organic $\mathrm{C}=$ Total $\mathrm{C}-\mathrm{C}$

from calcite/dolomite

Total carbon was obtained by heating a 
Table 1. Cover (\%) composition of patches dominated by different grasses.

\begin{tabular}{lccccc}
\hline \hline Patch dominant & $\begin{array}{c}\text { Dominant } \\
\text { grass }\end{array}$ & $\begin{array}{c}\text { Other } \\
\text { grasses }\end{array}$ & Forb & Litter & $\begin{array}{c}\text { Bare } \\
\text { ground }\end{array}$ \\
\hline Sideoats grama & $51 \mathrm{a}^{1}$ & $4 \mathrm{~b}$ & $5 \mathrm{a}$ & $26 \mathrm{ab}$ & $13 \mathrm{ab}$ \\
Buffalograss & $48 \mathrm{a}$ & $8 \mathrm{a}$ & $8 \mathrm{ab}$ & $22 \mathrm{~b}$ & $14 \mathrm{a}$ \\
Tobosagrass & $43 \mathrm{~b}$ & $9 \mathrm{a}$ & $9 \mathrm{~b}$ & $29 \mathrm{a}$ & $10 \mathrm{~b}$ \\
\hline
\end{tabular}

${ }^{1}$ Means in the same column with the same letter are not significantly different $(\mathrm{P}>0.05)$.

2-g sample to $950^{\circ} \mathrm{C}$, passing oxygen over the sample and collecting the $\mathrm{CO}_{2}$ in ascarite (Nelson and Sommers 1982). The content of calcite and dolomite was determined by a gasometric procedure after Dreimanis (1962). The P, K, Ca, Mg, Na and $\mathrm{S}$ contents were determined using the method of Hons et al. (1990) and pH was determined using the method of Schofield and Taylor (1955). The $\mathrm{N}$ content is expressed on a mg $\mathrm{NO}_{3}-\mathrm{N} \mathrm{kg}^{-1}$ basis and was determined using the method of Keeney and Nelson (1982).

\section{Statistical analyses}

To account for differences in initial plant size, relative growth rates for the 2year growth period are used in analyses (as per Evans 1972). Data were analyzed using analysis of variance and the Tukey means separation test (SAS Institute 1988) to test for differences in growth of juniper seedlings in the presence of different grasses in the grass competition study, soil temperature and soil nutrient status. The general linear model (SAS Institute 1988) was used to test for differences in herbaceous cover and treatment effects on juniper growth in the mesquite competition study.

\section{Results and Discussion}

\section{Environmental measurements}

Each patch containing juniper seedlings was comprised almost entirely of a single species. Cover of other grasses and forbs in each patch type was less than $10 \%$ (Table 1). Sideoats grama patches contained less other grasses and forbs $(\mathrm{P}<0.01)$ than buffalograss and tobosagrass patches. Litter cover and bare ground was similar in patches dominated by different grasses.

Soil temperature in each of the vegetation types differed $(\mathrm{P}<0.0001)$. Temperatures did not differ $(\mathrm{P}>0.05)$ between bare ground and beneath shortgrasses or between tallgrasses and mesquite canopies $(\mathrm{P}>0.05)$. However, soil temperature in the tallgrass and under mesquite canopies was cooler than in bare ground and shortgrass vegetation $(\mathrm{P}<$ $0.05)$. Time of day influenced soil temperature $(\mathrm{P}<0.0001)$. Soil temperature started the same at 0800 hours and then diverged between vegetation types $(\mathrm{P}<$ $0.0001)$ as the day temperature increased (Fig 1). In all vegetation types, soil temperature was significantly higher at 1200 than earlier in the day $(\mathrm{P}<0.05)$, but was not different at $1500(\mathrm{P}>0.05)$.

Soil water content in open grassland and under mesquite canopies was not different $(\mathrm{P}=0.59$ for brush * soil depth interaction). However, soil water content in open grassland at 600 to $900 \mathrm{~mm}$ and 900 to
$1,200 \mathrm{~mm}$ depths was lower $(\mathrm{P}<0.05)$ than in shallower soil layers of the grassland patches, and all soil layers under mesquite canopies. Soil nutrient analyses indicate greater $\mathrm{Mg}, \mathrm{S}$, and $\mathrm{Na}$ contents at $300 \mathrm{~mm}$ to $900 \mathrm{~mm}$ than at other depths (Table 2). Gypsum is associated with these depths and this layer is often impervious and can present a barrier to root penetration. The $\mathrm{C}$ and $\mathrm{N}$ contents were lower but $\mathrm{S}$ content was higher $(\mathrm{P}<0.05)$ in open grassland soils than in any of the mesquite canopy locations. Other nutrient contents were not different between vegetation types (Table 2). Soils beneath mesquite canopies have been found to have higher $\mathrm{C}$ and $\mathrm{N}$ contents than the surrounding grassland (Barth and Klemmedson 1978, 1982, Virginia et al. 1992).

\section{Grass competition study}

Juniper seedlings grew more in basal diameter and height $(\mathrm{P}<0.01)$ where all grass was removed than in the presence of any grasses (Table 3 ). Those growing with

Table 3. Relative growth rate (RGR) of juniper seedlings growing in the presence of different grass species.

\begin{tabular}{lcc}
\hline \hline Treatment & $\begin{array}{c}\text { RGR } \\
\text { Basal diameter }\end{array}$ & $\begin{array}{c}\text { RGR } \\
\text { Plant height }\end{array}$ \\
\hline Control & $\left(\mathrm{mm} \mathrm{mm}^{-1}\right)$ & $\left(\mathrm{cm} \mathrm{cm}^{-1}\right)$ \\
Buffalograss & $0.72 \mathrm{a}^{1}$ & $0.33 \mathrm{a}$ \\
Sideoats grama & $0.23 \mathrm{c}$ & $0.12 \mathrm{c}$ \\
Tobosagrass & $0.43 \mathrm{~b}$ & $0.22 \mathrm{~b}$ \\
\hline
\end{tabular}

${ }^{2}$ Means in the same column with the same letter are not significantly different $(\mathrm{P}>0.05)$

sideoats grama and tobosagrass grew more in basal diameter $(\mathrm{P}<0.01)$ than those with buffalograss. Juniper seedlings grew less in height with tobosagrass and buffalograss $(\mathrm{P}<0.01)$ than with sideoats grama or the no grass control. Woody

Table 2. Soil nutrient status in the open grassland or under the canopy of mesquite trees, under mesquite trees but with no root competition and in a sub-canopy position with the mesquite tree removed.

\begin{tabular}{|c|c|c|c|c|c|c|c|c|}
\hline & \multirow[b]{2}{*}{$\mathrm{pH}$} & \multicolumn{7}{|c|}{ Nutrient } \\
\hline & & $\mathrm{C}$ & $\mathrm{N}$ & $\mathrm{P}$ & $\mathrm{K}$ & $\mathrm{Mg}$ & $\mathrm{S}$ & $\mathrm{Na}$ \\
\hline & & $(\%)$ & 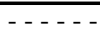 & $-\ldots$ & $\ldots \ldots$ & 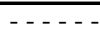 & $-\ldots-1$ & $-\ldots \ldots$ \\
\hline \multicolumn{9}{|l|}{ Soil depth (mm) } \\
\hline $0-150$ & $7.9 b^{1}$ & $2.1 \mathrm{a}$ & $5.4 \mathrm{a}$ & $61 \mathrm{a}$ & $648 \mathrm{a}$ & $514 \mathrm{c}$ & $146 \mathrm{~b}$ & $19 \mathrm{c}$ \\
\hline $150-300$ & $8.4 \mathrm{a}$ & $1.1 \mathrm{~b}$ & $1.4 \mathrm{~b}$ & $37 \mathrm{~b}$ & $461 \mathrm{~b}$ & $742 \mathrm{~b}$ & $311 \mathrm{~b}$ & $26 \mathrm{c}$ \\
\hline $300-600$ & $8.4 \mathrm{a}$ & $0.8 \mathrm{c}$ & $1.1 \mathrm{~b}$ & $34 \mathrm{~b}$ & $268 \mathrm{c}$ & $1101 \mathrm{a}$ & $757 \mathrm{~b}$ & $276 \mathrm{~b}$ \\
\hline $600-900$ & $8.1 \mathrm{~b}$ & $0.5 \mathrm{c}$ & $1.0 \mathrm{~b}$ & $47 \mathrm{ab}$ & $286 \mathrm{c}$ & $1160 \mathrm{a}$ & $1879 \mathrm{a}$ & $644 \mathrm{a}$ \\
\hline \multicolumn{9}{|l|}{ Treatment } \\
\hline Mesquite Canopy & $8.2 \mathrm{a}$ & $1.3 \mathrm{a}$ & $3.2 \mathrm{a}$ & $39 \mathrm{a}$ & $387 \mathrm{a}$ & $851 \mathrm{a}$ & $390 \mathrm{~b}$ & $163 \mathrm{~b}$ \\
\hline Mesquite removed & $8.3 \mathrm{a}$ & $1.2 \mathrm{ab}$ & $2.6 \mathrm{ab}$ & $56 \mathrm{a}$ & $408 \mathrm{a}$ & $907 \mathrm{a}$ & $683 \mathrm{~b}$ & $305 \mathrm{a}$ \\
\hline No Mesquite root & $8.1 \mathrm{a}$ & $1.1 \mathrm{ab}$ & $2.0 \mathrm{ab}$ & $46 \mathrm{a}$ & $455 \mathrm{a}$ & $864 \mathrm{a}$ & $210 \mathrm{~b}$ & $203 \mathrm{~b}$ \\
\hline Open Grassland & $8.4 \mathrm{a}$ & $0.9 \mathrm{~b}$ & $1.0 \mathrm{~b}$ & $37 \mathrm{a}$ & $414 \mathrm{a}$ & $895 \mathrm{a}$ & $1810 \mathrm{a}$ & $293 \mathrm{a}$ \\
\hline
\end{tabular}




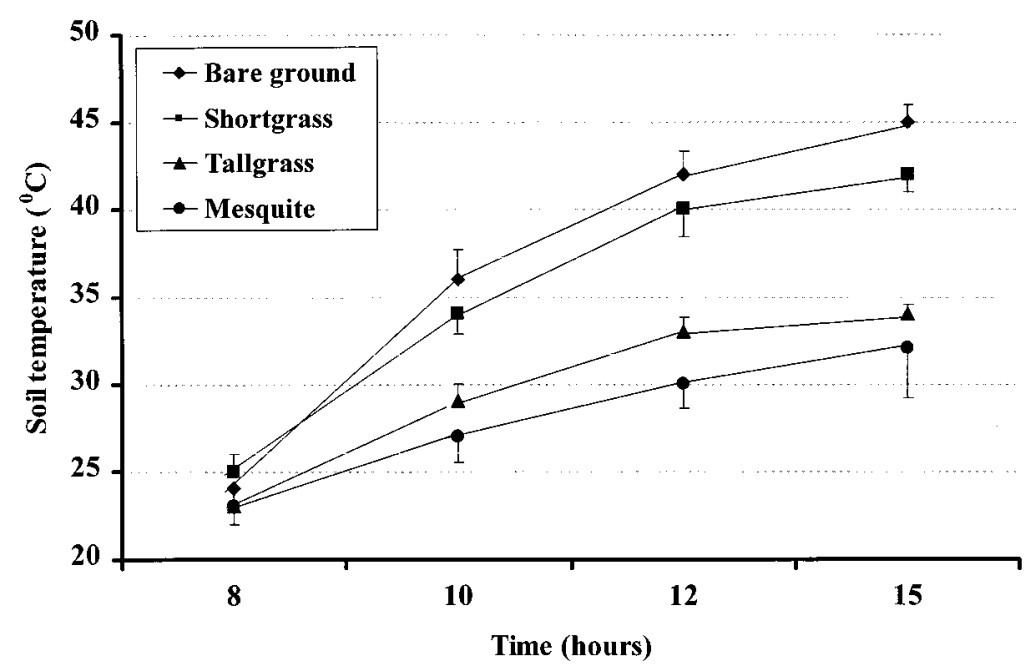

Fig. 1. Mean soil temperature at 1-cm depth for 6 days in June 1996 under bare ground, shortgrass, tallgrass and the canopy of mesquite trees. Bars indicate one-half of standard deviations for each time and location.

plant basal diameter is more closely related to plant biomass than plant height (Kramer and Kozlowski 1979) but when plant basal diameter differences are greater or smaller than plant height differences some differential effects on growth may be inferred. Greater height for a given biomass may indicate greater competition for light (Harper 1977).

In this study, juniper seedlings growing with buffalograss (short and palatable) grew less than those growing with sideoats grama (taller and palatable) or tobosagrass (taller and unpalatable). This was unexpected since taller grasses are generally more competitive than shorter grasses (Dyksterhuis 1958, Briske 1996) and palatable grasses are generally more competitive than unpalatable grasses (Moretto and Distel 1997). This indicates that the different growth rates of juniper seedlings in the presence of the different grasses in this study may be due to factors other than the differential competition of these species.

Soils under the taller, tufted grasses such as sideoats grama and tobosagrass have higher infiltration rates than shortgrasses like buffalograss (Thurow 1991). Although the amount of bare ground in sideoats grama patches was similar to buffalograss patches, but less than tobosagrass patches, the buffalograss patches were shorter and thus offered less shading of the soil surface. Litter cover was also less in the buffalograss patches $(\mathrm{P}<0.01)$ offering less shading of the soil surface than in sideoats grama and tobosagrass patches. This resulted in midgrass species, sideoats grama and tobosagrass, reducing soil temperature more (Fig 1) than the short buffalograss. Reduced growth of juniper seedlings in the buffalograss patches is probably related to the more stressful conditions in these shortgrass patches. Higher infiltration rates and shade levels may have resulted temperatures in the patches dominated by sideoats grama and tobosagrass, resulting in a less stressful micro-environment and higher growth rates of juniper seedlings observed in this study. The possibility that buffalograss patches were associated with patches of more droughty soils also needs to be investigated.

\section{Mesquite competition study}

Juniper seedlings in open grassland grew less $(\mathrm{P}<0.05)$ in basal diameter and height than those under any of the differently treated mesquite canopies (Table 4). Soil nutrient status appears to be more limiting to juniper seedling growth in the open grassland than in the mesquite canopy positions. The basal diameter of seedlings growing with mesquite canopy removed, increased less $(\mathrm{P}<0.05)$ than those growing under intact mesquite

Table 4. Relative growth rate (RGR) of juniper seedlings growing in open grassland or under the canopy of mesquite trees, under mesquite trees but with no root competition and in a subcanopy position with the mesquite tree removed.

\begin{tabular}{lcc}
\hline \hline Treatment & RGR & RGR \\
& Basal diameter & $\begin{array}{c}\text { Plant height } \\
\text { Pm mm }\end{array}$ \\
\hline Open grassland & $\left(\mathrm{mm} \mathrm{m}^{-1}\right)$ & $\left(\mathrm{cm} \mathrm{cm}^{-1}\right)$ \\
Canopy with root competition & $0.65 \mathrm{c}^{1}$ & $0.22 \mathrm{c}$ \\
Canopy with no root competition & $0.99 \mathrm{a}$ & $0.33 \mathrm{ab}$ \\
Canopy removal & $0.93 \mathrm{ab}$ & $0.37 \mathrm{a}$ \\
\hline
\end{tabular}
probably favors juniper growth. Most seedling mortality in other juniper species occurs during the hot dry months and is higher in open grassland than at the edge of established woody plants (Johnsen 1962, Burkhardt and Tisdale 1976, Jackson and Van Auken 1997). In this study taller grass also ameliorated temperatures in summer resulting in greater growth rates of juniper. It is also possible that hydraulic lift (Dawson 1993) may have influenced results. Seedlings under intact mesquite canopies grew more than seedlings with either isolated soil or with the tree canopy removed. These last 2 situations would not have hydraulic lift whereas the former may have.

The common occurrence of juniper seedlings growing under established mesquite canopies (McPherson et al. 1988) might also indicate that these plants are tolerant of lower light levels found in sub-canopy positions (Jackson and Van Auken 1997). It is possible that full sunlight may be a less favorable environment for young juniper plants than the partial shade of a mesquite canopy. In this study juniper growing under a mesquite canopy, in greater amounts of soil water and cooler

canopies with full root competition or with no root competition. A healthy grass sward is more limiting to growth of juniper seedlings than the canopy of mesquite trees. Mesquite trees clearly provide a relatively favorable environment for juniper seedlings. This must be due in part to the greater nutrient availability under mesquite canopies than in the surrounding grassland. Juniper growth in the presence of sub-canopy grasses with the mesquite tree removed was intermediate between those growing beneath intact mesquite trees and those growing in open grassland. However, it is counter-intuitive that seedlings growing with the mesquite trees removed grew less than those growing under an intact mesquite canopy with full root competition. The soil nutrient status was not different at these 2 locations. Low levels of shading under mesquite canopies ameliorate the temperature during periods of high temperature stress (Fig. 1) that

${ }^{1}$ Means in the same column with the same letter are not significantly different $(\mathrm{P}>0.05)$ 
but without mesquite root competition, grew no better than those with mesquite root competition, indicating that mesquite root competition with juniper is probably inconsequential. Since juniper grows mainly in fall, winter and spring when mesquite trees are dormant and leafless, lack of competition between these 2 woody species may largely be due to using resources at different times of the year. The higher nutrient availability beneath mesquite canopies, reduction of summer temperatures, and temporal separation of resource use clearly benefit juniper plants growing in the presence of mesquite trees compared to those growing in open grassland.

Clearly, managing for a vigorous grass component with low densities and cover of mesquite is the best way to limit the rate of invasion by juniper. Although juniper grew less with buffalograss than either sideoats grama or tobosagrass, this response may largely be due to microsite differences rather than the relative competitiveness among them. There is a need to determine how much the growth of juniper seedlings is impeded by competition with different grass species relative to possible microsite differences associated with the different species.

\section{Literature Cited}

Barth, R.C. and J.O. Klemmedson. 1978. Shrub-induced spatial patterns of dry matter, nitrogen and organic carbon. Soil Sci. Soc. Amer. J. 42:804-808.

Barth, R.C. and J.O. Klemmedson. 1982. Amount and distribution of dry matter, nitrogen and organic carbon in soil-plant systems of mesquite and Palo-verde. J. Range Manage. 35:412-418.

Briske, D.D. 1996. Strategies of plant survival in grazed systems: A functional interpretation, p. 37-67. In: J. Hodgson and A.W Illius (eds.), The ecology and management of grazing systems. CAB International, London.

Burkhardt, J.W. and E.W. Tisdale. 1976. Causes of juniper invasion in southwestern Idaho. Ecol. 57:472-484.

Dawson, T.E. 1993. Hydraulic lift and water use by plants - Implications for water balance, performance and plant-plant interactions. Oecologia 95:565-574.

Dreimanis, A. 1962. Quantitative gasometric determination of calcite and dolomite by using the Chittick apparatus. J. Sedimentary Petrology 32:520-529.

Dye, K.L., D.N. Ueckert, and S.G. Whisenant. 1995. Redberry juniper-herbaceous understory interactions. J. Range Manage. 48:100-107.

Dyksterhuis, E.J. 1958. Ecological principles in range evaluation. Bot. Rev. 24:253-272.
Evans, G.C. 1972. The quantitative analysis of plant growth. Blackwell, London

Fuhlendorf, S. D., F. E. Smeins, and W. E. Grant. 1996. Simulation of a fire-sensitive ecological threshold: A case study of Ashe juniper on the Edwards Plateau of Texas, USA. Ecol. Model. 90: 245-255.

Harper, J.L. 1977. Population biology of plants. Academic Press, London.

Hons, F.M., L.A. Larson-Vollmer, and M.A. Locke. 1990. $\mathrm{NH}_{4} \mathrm{O}$ ac-EDTA extractable phosphorus as a soil test procedure. Soil Sci. 149:249-256.

Jackson J.T. and O.W. van Auken. 1997. Seedling survival, growth and mortality of Juniperus ashei (Cupressacae) in the Edwards plateau region of central Texas. Texas J. Sci. 49:267-278.

Johnsen, T.N. 1962. One-seeded juniper invasion of northern Arizona grasslands. Ecol. Monogr. 32:187-207.

Johnson, P., A. Gerbolini, D. Ethridge, C. Britton, and D. Ueckert. 1999. Economics of redberry juniper control in the Texas Rolling Plains. J. Range Manage. 52:569-574.

Keeney, D.R. and D.W. Nelson. 1982. Nitrogen-inorganic forms, p. 643-698. In: A.L. Page, R.H. Miller, and D.R. Keeney (eds.), Methods of soil analysis. Part 2. Amer. Soc. Agron. Madison, Wis.

Kramer, P.J. and Kozlowski, T.T. 1979. Physiology of woody plants. Academic Press, New York.

McPherson, G.R. and H.A. Wright. 1987. Factors affecting reproductive maturity of redberry juniper (Juniperus pinchotii). Forest. Ecol. Manage. 21:191-196.

McPherson, G.R., H.A. Wright, and D.B. Wester. 1988. Patterns of shrub invasion in semi-arid Texas grasslands. Amer. Midland Naturalist 120:391-397.

Moretto, A.S. and R.A. Distel. 1997. Competitive interactions between palatable and unpalatable grasses native to a temperate semi-arid grassland of Argentina. Plant Ecol. 130:155-161.

Nelson, D.W. and L.E. Sommers. 1982. Total carbon, organic carbon and organic matter, $\mathrm{p}$. 539-579. In: A.L. Page, (ed.), Methods of soil analysis, Part 2. Agronomy Monograph 9. 2nd Ed. Soil Sci. Soc. Amer. Madison, Wis.

SAS Institute. 1988. SAS/STAT user's guide. SAS Institute, Cary, N.C.

Scifres, C.J. 1980. Brush management principles and practices for Texas and the southwest. Texas A\&M Univ. Press, College Station, Tex.

Schofield, R.K. and A.W. Taylor. 1955. The measurement of soil pH. Soil Sci. Soc. Amer. Proc. 19:164-167

Smith, M.A., H.A. Wright, and J.L. Schuster. 1975. Reproductive characteristics of redberry juniper. J. Range Manage. 28:126-128.
Thurow, T.L. 1991. Hydrology and erosion, p. 141-160. In: R.K. Heitschmidt and J.W. Stuth (eds). Grazing management: An ecological perspective. Timber Press, Portland, Ore.

Van Auken, O.W. 1993. Size distribution patterns and potential population change of some dominant woody species of the Edwards plateau region of Texas. Texas J. Sci. 45:199-210.

Virginia, R.A., W.M. Jarrell, W.G. Whitford, and D.W. Freckman. 1992. Soil biota and soil properties in the surface-rooting zone of mesquite (Prosopis glandulosa) in historical and recently desertified Chihuahuan desert habitats. Biol. Fertil. Soils 14:90-98 


\title{
Effects of prescribed fire on sand shinnery oak communities
}

\author{
WADE C. HARRELL, SAMUEL D. FUHLENDORF, AND TERRENCE G. BIDWELL
}

Authors are graduate assistant, assistant professor and professor at Oklahoma State University, Department of Plant and Soil Sciences, Stillwater, Okla. $74074-6028$

\begin{abstract}
Sand shinnery oak (Quercus havardii Rydb.) communities are shrublands extending from northern Texas and western Oklahoma southward into the Chihuahuan Desert. They are dominated by sand shinnery oak, a member of the white oak group. Structure and composition of sand shinnery oak communities in relation to natural disturbances, such as fire, have not been adequately investigated. The objectives of this study were to determine the influence of fire on shrub composition and vegetation structure of sand shinnery oak communities, and to determine the persistence of structural and compositional changes. Data were collected on Black Kettle National Grassland (BKNG) in western Oklahoma during the growing seasons of 1998 and 1999. Vegetation measurements included line transects, visual obstructions, heights, cone of vulnerabilities, shrub patch sizes, and shrub patch densities were used to estimate functional group canopy cover, shrub composition, and structure of sand shinnery oak communities. One growing season after fire, burned sand shinnery oak communities had significantly less shrub cover $(\mathrm{P}<$ $0.01)$ than unburned communities ( 38 vs. $51 \%$ ). Height of vegetation was lower 1 and 2 growing seasons after fire $(26$ and $35 \mathrm{~cm}$, respectively) $(P<0.05)$ than unburned communities $(44 \mathrm{~cm})$. Visual obstruction was lower the first $(30 \%)$ and second $(40 \%)$ year after fire $(P<0.01)$ compared to unburned communities $(59 \%)$. Cone of vulnerability indicated significantly more open structure one growing season after fire. After 4 growing seasons, all measures of structure in burned communities were similar to those in unburned communities. We found no differences in composition of shrub species between burned and unburned sites ( $P$ $=0.55$ ). Two fire events, 2 growing seasons apart, had less influence on vegetation structure than the initial fire. Sand shinnery oak communities appear to be highly resilient to periodic disturbance by fire. Prescribed fire is an effective tool for short-term alteration (< 3 growing seasons) of sand shinnery oak structure; however, rapid recovery following fire does not indicate any long-term changes in vegetation structure and composition.
\end{abstract}

Key Words: lesser prairie-chicken, northern bobwhite, prairie, shrubland, succession, stability, vegetation structure, woody plants

We thank Dr. Fred Guthery for review of the ecological content of the manuscript and Mark Payton from the Oklahoma State University Statistics Department for review of statistical content. Approved for publication by the Director, Oklahoma Agricultural Experiment Station and funded by the U. S. Forest Service and the Oklahoma Agricultural Experiment Station. We also thank Robert Chapman, Kimberly Suedkamp, and Timothy Tunnell for field assistance.

Manuscript accepted 18 Dec. 00.

\section{Resumen}

Las comunidades de "Sand shinnery oak" (Quercus havardii Rydb.) son matorrales que se extienden desde el norte de Texas y oeste de Oklahoma hacia el sur del desierto Chihuahense. Ellas están dominados por "Sand shinnery oak", un miembro del grupo de los encinos blancos. La estructura y composición de las comunidades de "Sand shinnery oak" en relación a los disturbios naturales, tales como el fuego, no han sido investigados adecuadamente. Los objetivos de este estudio fueron determinar la influencia del fuego en la composición de los arbustos y la estructura de la vegetación de las comunidades de "Sand shinnery oak" y determinar la persistencia de los cambios estructurales y composicionales. Los datos se colectaron en el Pastizal Nacional de Black Kettle (BKNG), situado en el oeste de Oklahoma, durante las estaciones de crecimiento de 1998 y 1999. Las mediciones de vegetación incluyeron el transecto de línea, obstrucciones visuales, alturas, vulnerabilidad de conos, tamaño del parche de los arbustos y densidades de parches de arbustos, los cuales se usaron para estimar la cobertura de copa de los grupos funcionales, la composición de arbustos y la estructura de las comunidades de "Sand shinnery oak ". Una estación de crecimiento después de que el fuego quemó las comunidades de "Sand shinnery oak" estas tenían una cobertura de arbustos significativamente menor $(P<0.01)$ que las comunidades no quemadas (38 vs. $51 \%$ ). La altura de la vegetación de las comunidades quemadas fue menor una y dos estaciones de crecimiento después del fuego ( 26 and $35 \mathrm{~cm}$, respectivamente) $(\mathrm{P}<0.05)$ que la altura de las comunidades no quemadas $(44 \mathrm{~cm})$. La obstrucción visual fue menor en el primer (30\%) y segundo $(40 \%)$ años después del fuego $(P<0.01)$ comparado con las comunidades sin quemar $(59 \%)$. Un año después del fuego, la vulnerabilidad del cono indicó una estructura significativamente más abierta. Después de 4 estaciones de crecimiento, todas las medidas de la estructura de las comunidades quemadas fueron similares a las de las comunidades sin quemar. No encontramos diferencias en la composición de especies de arbustos entre los sitios quemados y sin quemar $(P=0.55)$. Dos eventos de fuego, en dos estaciones de crecimiento separadas, tuvieron menos influencia en la estructura de la vegetación que el fuego inicial. Las comunidades de "Sand shinnery oak" parecen ser altamente flexibles a disturbios periódicos por fuego. El fuego prescrito es una herramienta efectiva para una alteración de corto plazo $(<3$ estaciones de crecimiento) de la estructura del "Sand shinnery oak", sin embargo, la rápida recuperación después del fuego no indica algún cambio a largo plazo en la estructura y composición de la vegetación. 
Sand shinnery oak (Quercus havardii Rydb.) communities occupy 2 to 3 million ha extending from northern Texas and western Oklahoma southward into the Chihuahuan Desert. Historical accounts of sand shinnery oak rangelands in western Oklahoma document a dense growth of dwarf vegetation about $45 \mathrm{~cm}$ high which seemed to have attained full maturity (Marcy 1854). It has been suggested that sand shinnery oak communities were once dominated by tallgrasses, but the increase of livestock grazing and the decrease in fire has allowed sand shinnery oak to gain dominance and reduce the cover of tallgrasses (Hodson et al. 1980, Conner et al. 1974). Based on this assumption, many land managers have attempted to control sand shinnery oak with herbicides to improve forage quantity for livestock, resulting in fragmented sand shinnery oak communities (Bailey and Painter 1994, Dhillion et al. 1994, Peterson and Boyd 1998). Control efforts with herbicide may stem from early classifications of sand shinnery oak as an invader by the Natural Resource Conservation Service (NRCS) (Conner et al. 1974, Hodson et al. 1980, Peterson and Boyd 1998). Lack of documented reproduction by seed and reconstruction of composition in the pollen record characterizing a stable existence for hundreds of years question the invasive classification of this species (Gross and Dick-Peddie 1979, Peterson and Boyd 1998).

Fire is critical to conservation on much of the Great Plains (Axelrod 1985), however its importance is not well understood for sand shinnery oak communities. It is surmised that alterations in fire and grazing regimes since European settlement may have increased density, cover, and altered spatial arrangement of sand shinnery oak communities. However, some reports suggest that shrub abundance is not drastically altered by natural disturbances such as fire (McIlvain and Armstrong 1966, Boyd 1999) suggesting that sand shinnery oak communities are resilient. Therefore, our objectives were to evaluate sites within sand shinnery oak communities with varying fire histories to 1) quantify structural and compositional influences of fire, 2) determine the rate of recovery following single fire events, and 3) determine the interactive effects of time since fire and the number of recent fires on vegetation structure.

\section{Study Area and Methods}

Our study sites were selected in sand shinnery oak communities on the Black Kettle National Grassland (BKNG) in Roger Mills County, Oklahoma (35 $37^{\circ} \mathrm{N}$ $\left.100^{\circ} 40^{\prime} \mathrm{W}\right)$. The climate of the region is semiarid, with mean August and January temperatures of $28.0^{\circ} \mathrm{C}$ and $2.7^{\circ} \mathrm{C}$, respectively (Burgess et al. 1963, Dhillion and Mills 1999). The area has an average growing season of 209 days, with a mean rainfall of $65 \mathrm{~cm}$ (Burgess et al. 1963). Precipitation is highly variable with a bimodal distribution of rainfall with peaks in May-June and August-September. Topography of the area consists of rolling hills, with variable altitudes ranging from 518 to $793 \mathrm{~m}$ above sea level.

Sites were located on sand shinnery oak communities within deep sand savannah and sandy prairie range sites (Burgess et al. 1963). Sand shinnery oak dominates these sites with sand sage (Artemisia filifolia Torr.) a subdominant (Peterson and Boyd 1998). Common grasses include sand bluestem (Andropogon gerardii var. paucipilus Nash), little bluestem (Schizachyrium scoparium Nash), and sideoats grama (Bouteloua curtipendula Torr.). Nomenclature follows Hatch et al. (1990). Preliminary data analysis indicated that both ecological sites were similar in vegetation structure, composition, and response to fire indicating that they may have been misclassified; thus, further analyses combined both ecological sites into a single ecological type. All sites sampled were grazed by cattle at light to moderate rates (ca. 1.5 haAUM $^{-1}$ ) relative to NRCS recommendations.

Sites sampled varied with time since fire and number of fires including single event fires that occurred $1(n=4), 2(n=4)$ and $4(\mathrm{n}=2)$ growing seasons prior to sampling, 2 event fires that occurred $1,3(\mathrm{n}=$ $2)$ and 2, $4(n=2)$ growing seasons prior to sampling, and unburned sites $(n=4)$. All prescribed fires were conducted during the spring (February-May). Each experimental unit (Black Kettle National Grassland Unit, 30 - 130 ha) was sampled once during the late growing season of 1998 or 1999 . Four, 100-m line transects per unit $(18$ units $\times 4$ transects $=72$ line transects) were used to measure canopy cover of plant functional groups at a 10$\mathrm{cm}$ interval (Bonham 1989). This sampling resolution was used so that smallscale changes in structure that may be important to some wildlife species such as northern bobwhite (Colinus virginianus L.) and lesser prairie-chicken (Tympanuchus pallidicinctus Ridgeway) could be detected. Canopy cover of functional groups (shrubs, herbaceous vegetation, and litter) was sampled along each line. Shrub cover was measured as an absolute value along the transect, with all other functional groups recorded only in the absence of shrub cover. Shrub patch number (\# / 100 $\mathrm{m})$ and average size of shrub patches $(\mathrm{cm})$ were determined from the line transect data by summing the number of distinct shrub patches and averaging their linear lengths. A distinct shrub patch along the transect could be as small as $10 \mathrm{~cm}$ and was defined as continuous shrub cover along the line without a canopy break greater than $10 \mathrm{~cm}$. Frequency of each shrub species was determined by dividing number of occurrences of a shrub patch for a given species by the total number of shrub patches for each transect.

Measurements of vegetation height were taken at a point every $1 \mathrm{~m}$ along the transect. We estimated visual obstruction every $10 \mathrm{~m}$ along the transect using a profile board as described by Nudds (1977) and modified for sand shinnery oak communities by Guthery et al. (1981). The $6.8-\mathrm{cm}$ wide profile board had 12 strata, each stratum being $10 \mathrm{~cm}$ tall. Estimates were taken perpendicular to the line transect at a distance of $7 \mathrm{~m}$, with the observer kneeling at a height of $1.5 \mathrm{~m}$ over the transect. Percent visual obstruction was estimated for each stratum. We measured cone of vulnerability (Kopp et al. 1998) every $10 \mathrm{~m}$ along the transects. The cone of vulnerability is a 3-dimensional view of visual obstruction and has been identified as a measure that quantifies habitat structure important for northern bobwhites (Kopp et al. 1998). A larger cone of vulnerability equates to a structurally more open habitat. We measured cone of vulnerability by recording 8 angles around a point $10 \mathrm{~cm}$ above ground level to the top of the nearest obstructing vegetation. We then calculated the volume of the air space included within the cone formed by the angles (Kopp et al. 1998).

We used a completely randomized design to evaluate the effects of fire and recovery time from fire on vegetation structure in sand shinnery oak communities. Sites in which single event fires occurred, including sites burned 1,2, and 4 growing seasons prior to sampling and unburned sites were considered treatments. Statistical differences in time since fire for percent cover (shrub, herb, and litter), vegetation height, average visual obstruction, cone of vulnerability, shrub 
patch size, and shrub patch number were assessed using one-way analysis of variance (PROC MIXED, SAS Institute Inc. 1988). The mixed procedure with Satterthwaith's approximation for degrees of freedom was used. Differences between means at varying time since fire were determined using least square means $(\mathrm{P}<0.05)$. We used multivariate analysis of variance methods (MANOVA, Wilk's Lambda statistic) to test for differences in shrub species composition among treatments (Stroup and Stubbendieck 1983).

We used a $2 \times 2$ factorial arrangement of treatments employing paired factors of time since fire and number of times burned (PROC MIXED, SAS Institute Inc. 1988) to determine the interactive effects of time since fire and the number of recent fires on structure within sand shinnery oak communities. Sites that were included in the analysis consisted of single event fires, 1 and 2 growing seasons prior to sampling and 2 event fires, 1, 3 and 2, 4 growing seasons prior to sampling. This analysis focused on the interaction between the main effects of time since fire and number of times burned.

We employed repeated measures using MANOVA (PROC GLM, SAS Institute Inc. 1988) to analyze the interaction between treatment and strata for visual obstruction along our density board. Visual obstruction of each stratum was not an independent observation, but was dependent on the visual obstruction of other strata, hence strata were repeated measures in this analysis. All possible time since fire combinations (treatments) were used to test for significant interactions with strata in the analysis of visual obstruction.

\section{Results}

\section{Fire effects and rate of recovery}

Sand shinnery oak was the dominant cover on all sites (Table 1). Other shrubs that occurred included sandsage, skunkbush (Rhus aromatica Ait.), sand plum (Prunus spp. L.), soapweed yucca (Yucca glauca Nutt.), netleaf hackberry (Celtis reticulata Torr.), leadplant (Amorpha canescens Nutt.), honey mesquite (Prosopis glandulosa Torr.), and catclaw mimosa (Mimosa biuncifera Benth.). We found no differences ( $\mathrm{P}=$ $0.55)$ in composition of shrub species between burned and unburned sites.

Analysis for differences among time since fire (1, 2, 4 growing seasons since fire and unburned) indicated differences $(\mathrm{P}$
Table 1. Frequency of occurrence (\%) and standard error (SE) of shrub species in sand shinnery oak communities of Black Kettle National Grassland, Okla. following prescribed fire, 1998-1999.

\begin{tabular}{|c|c|c|c|c|}
\hline \multirow[b]{2}{*}{ Shrub species } & \multicolumn{3}{|c|}{ Time since fire (growing seasons) } & \multirow[b]{2}{*}{$\begin{array}{c}\text { Unburned } \\
\mathrm{n}=4\end{array}$} \\
\hline & $\begin{array}{c}1 \\
n=4\end{array}$ & $\begin{array}{c}2 \\
n=4\end{array}$ & $\begin{array}{c}4 \\
n=2\end{array}$ & \\
\hline $\begin{array}{l}\text { Sand Shinnery-Oak } \\
\text { (Quercus havardii) }\end{array}$ & $94(1.3)^{1}$ & $98(0.79)$ & $96(0.08)$ & $96(1.14)$ \\
\hline $\begin{array}{l}\text { sandsage } \\
\quad \text { (Artemisia filifolia) }\end{array}$ & $9.4(3.3)$ & $4.5(1.08)$ & $7.9(1.73)$ & $8.0(2.16)$ \\
\hline $\begin{array}{l}\text { skunkbush } \\
\quad(\text { Rhus aromatica) }\end{array}$ & $2.6(1.88)$ & $2.1(0.84)$ & $0.40(0.40)$ & $2.0(1.40)$ \\
\hline $\begin{array}{l}\text { sand plum } \\
\text { (Prunus spp.) }\end{array}$ & $1.1(0.91)$ & $0.92(0.66)$ & $0.27(0.27)$ & $1.66(1.58)$ \\
\hline $\begin{array}{r}\text { soapweed yucca } \\
(\text { Yucca glauca })\end{array}$ & $0.41(0.08)$ & $0.12(0.12)$ & $0.40(0.40)$ & $0.82(0.40)$ \\
\hline $\begin{array}{l}\text { netleaf hackberry } \\
\text { (Celtis reticulata) }\end{array}$ & $0(0)$ & $0(0)$ & $0.40(0.40)$ & $0.07(0.07)$ \\
\hline $\begin{array}{l}\text { leadplant } \\
\text { (Amorpha canescens) }\end{array}$ & $0(0)$ & $1.83(1.83)$ & $0(0)$ & $0.42(0.42$ \\
\hline $\begin{array}{l}\text { catclaw mimosa } \\
\text { (Mimosa biuncifera) }\end{array}$ & $0.25(0.25)$ & $0(0)$ & $0(0)$ & $0.07(0.07)$ \\
\hline $\begin{array}{l}\text { honey mesquite } \\
\text { (Prosopis glandulosa) }\end{array}$ & $0.06(0.06)$ & $0(0)$ & $0(0)$ & $0(0)$ \\
\hline
\end{tabular}

${ }^{1}$ Standard error
$<0.01$ ) for all 3 cover types (shrub, herb, litter) (Table 2). Shrub cover decreased the first growing season after fire $(\mathrm{P}<0.01)$, yet was comparable to that of unburned sites by 2 growing seasons $(\mathrm{P}=0.26)$ and 4 growing seasons $(\mathrm{P}=0.33)$ after a fire. Litter cover decreased the first growing season $(\mathrm{P}<0.01)$ and second growing season $(\mathrm{P}<0.01)$ following burning, but was similar to unburned sites after four growing seasons $(P=0.09)$. Herbaceous cover was higher on sites burned 1 growing season $(\mathrm{P}<0.01)$ and 2 growing seasons prior $(\mathrm{P}=0.05)$ than on unburned sites, but was similar to unburned areas 4 growing seasons after a single fire $(\mathrm{P}=0.07)$.

Measures of structure (height, cone of vulnerability, shrub patch number, shrub patch size, and visual obstruction) in sand shinnery oak communities indicated that fire changed structure $(\mathrm{P}<0.05)$, but the effect was short lived $(<4$ growing seasons) (Table 2). Average height of vegetation differed among time since fire treatments $(\mathrm{P}<0.01)$. Fire decreased vegetation height for 1 growing season $(\mathrm{P}<$ $0.01)$ and 2 growing seasons $(P=0.04)$ post burn, but vegetation height after 4 growing seasons did not differ from unburned sites $(\mathrm{P}=0.82)$. The cone of vulnerability increased 1 growing season after fire $(\mathrm{P}<0.01)$, but was similar to unburned sites by the second $(\mathrm{P}=0.81)$ growing season following fire.

One growing season following fire, shrub patch number averaged 92/100 m, but was higher 2 growing seasons following a fire $(\mathrm{P}<0.01)$ (Table 2$)$. Two
Table 2. The effect of time since fire on structural and compositional responses of sand shinnery oak communities following prescribed fire at Black Kettle National Grassland, Okla. (1998-1999). Means in rows sharing the same letters are similar $(P>0.05)$ by least significant means test.

\begin{tabular}{lcccc}
\hline \hline & \multicolumn{4}{c}{ Time since fire (growing seasons) } \\
\cline { 2 - 5 } Shrub species & 1 & 2 & 4 & Unburned \\
& $\mathrm{n}=4$ & $\mathrm{n}=4$ & $\mathrm{n}=2$ & $\mathrm{n}=4$ \\
\hline Cone of Vulnerability $\left(\mathrm{m}^{3} \times 10^{-3}\right)$ & $1105 \mathrm{a}$ & $492 \mathrm{~b}$ & $445 \mathrm{~b}$ & $514 \mathrm{~b}$ \\
Height $(\mathrm{cm})$ & $26 \mathrm{a}$ & $35 \mathrm{~b}$ & $42 \mathrm{bc}$ & $44 \mathrm{c}$ \\
Shrub (\%) & $38 \mathrm{a}$ & $56 \mathrm{~b}$ & $56 \mathrm{~b}$ & $51 \mathrm{~b}$ \\
Litter $(\%)$ & $22 \mathrm{a}$ & $21 \mathrm{a}$ & $34 \mathrm{~b}$ & $34 \mathrm{~b}$ \\
Herb (\%) & $37 \mathrm{a}$ & $21 \mathrm{bc}$ & $7 \mathrm{~d}$ & $14 \mathrm{~cd}$ \\
Shrub Patch size $(\mathrm{cm})$ & $41 \mathrm{a}$ & $51 \mathrm{ab}$ & $62 \mathrm{~b}$ & $52 \mathrm{ab}$ \\
Shrub Patch number (no. /100 m) & $92 \mathrm{a}$ & $110 \mathrm{~b}$ & $93 \mathrm{a}$ & $103 \mathrm{ab}$ \\
Visual Obstruction $(\%)$ & $30 \mathrm{a}$ & $40 \mathrm{~b}$ & $57 \mathrm{c}$ & $59 \mathrm{c}$
\end{tabular}


growing seasons following fire, shrub patch number averaged $110 / 100 \mathrm{~m}$, but decreased 4 growing seasons after a fire to $93 / 100 \mathrm{~m}(\mathrm{P}=0.03)$. Shrub patch number in unburned sites averaged 103/100 m, which was similar to that found in all burned sites. Shrub patch size was smallest $(41 \mathrm{~cm}) 1$ growing season after fire, and greatest $(62 \mathrm{~cm}) 4$ growing seasons after fire $(\mathrm{P}<0.01)$ (Table 2).

A single fire lowered visual obstruction values 1 growing season $(\mathrm{P}<0.01)$ and 2 growing seasons $(\mathrm{P}<0.01)$ post burn, but visual obstruction after 4 growing seasons was comparable to unburned sites $(\mathrm{P}=$ $0.81)$. Visual obstruction estimates were significantly different for the strata by treatment interaction $(\mathrm{P}<0.01)$ (Fig. 1). After 4 growing seasons, visual obstruction of sand shinnery oak communities was similar to unburned sites for all strata.

\section{Number of fires and time since fire interaction}

We tested the interaction of time since fire and number of burns to determine the influence of fire in sand shinnery oak communities, and main effects $(\mathrm{P}<0.05)$ were detected for all of the variables analyzed (Table 3). An interaction between number of fires and time since fire occurred for cone of vulnerability $(\mathrm{P}=$

Table 3. The effect of time since fire (TSF) and number of fires (NF) interaction on structural responses of sand shinnery oak communities following prescribed fire at Black Kettle National Grassland, Okla. (1998-1999). Significant interactions $(P<0.05)$ are indicated by TSF $\times$ NF, and significant main effects $(P<0.05)$ are indicated by TSF, NF.

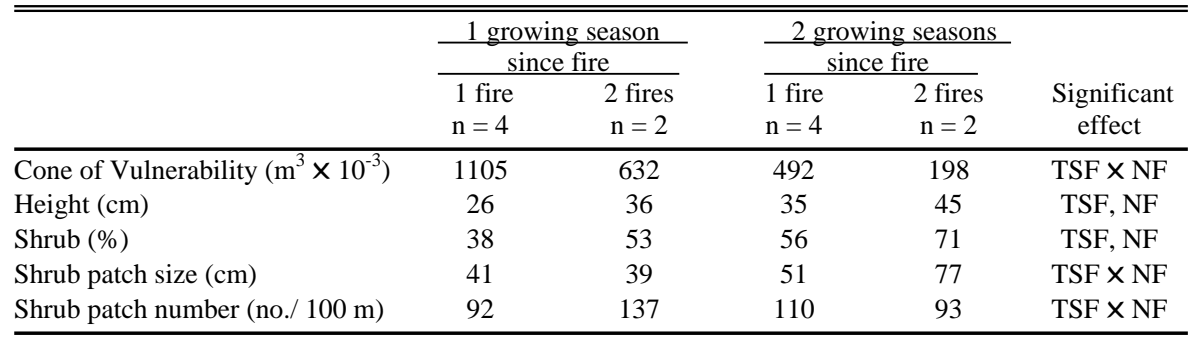

$0.04)$, shrub patch number $(\mathrm{P}<0.01)$

(Table 3$)$ and shrub patch size $(\mathrm{P}<0.01)$.

Shrub cover did not have an interaction $(\mathrm{P}=0.95)$; however, both main effects, number of fires $(\mathrm{P}<0.01)$ and time since fire $(\mathrm{P}<0.01)$ were significant. Shrub cover increased with time since fire and after more than a single fire (Table 3 ). Shrub cover was greater $(62 \%)$ on sites burned twice than on those burned only once $(47 \%)$. Height did not have an interaction $(\mathrm{P}=0.92)$, but increased with time since fire $(\mathrm{P}<0.01)$ and number of fires $(\mathrm{P}<0.01)$. Average vegetation height for sites burned twice was $40.4 \mathrm{~cm}$, while sites burned once averaged $31 \mathrm{~cm}$. The cone of vulnerability had a significant

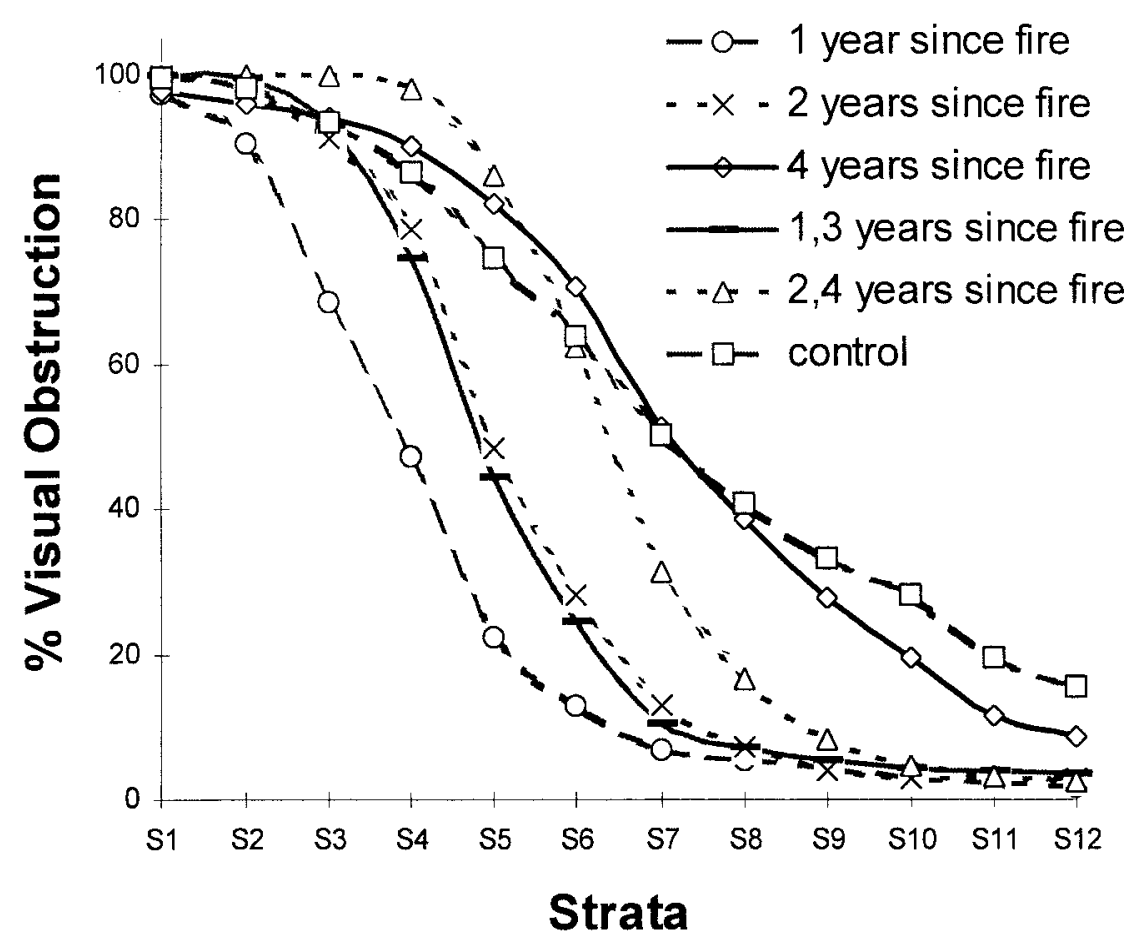

Fig. 1. Visual obstruction profiles in sand shinnery oak communities following prescribed fire at Black Kettle National Grassland, Oklahoma 1998-1999. S1-S12 represents increasing height from ground-level (S1) to $120 \mathrm{~cm}$ (S12). Legend indicates the visual obstruction curves for time since fire treatments $(P<0.05$, Wilk's Lambda statistic). interaction $(\mathrm{P}=0.04)$. Cone of vulnerability was greater (more open structurally) following a single fire than after two fires $(\mathrm{P}<0.01)$. Decrease in the cone of vulnerability following 2 fires was more rapid than after a single fire (Table 3). Patch number had an interaction $(\mathrm{P}<0.01)$. For single fires, shrub patch number increased with increasing time since fire, but decreased with increasing time since fire on twice burned sites. Shrub patch size also had an interaction $(\mathrm{P}<0.01)$. Shrub patch size increased at a greater rate after the second fire compared with single event fires.

\section{Discussion}

In the Great Plains, as well as other rangelands, many changes in vegetation structure and composition are caused by altered fire regimes (Hanes 1971, Axelrod 1985). The importance of time since fire and number of fires on structure of sand shinnery oak communities was largely unknown, but rapid resprouting following fire has been recognized (McIlvain and Armstrong 1966, Boyd 1999). Other oak communities, such as those dominated by Madrean oak (Quercus emoryi Torr.) in Mexico have rapidly recovered following fire (Ffolliott and Bennett 1996). However, composition and structure of the chaparral communities in southern California did not exhibit this rapid recovery from periodic disturbances with changes lasting as long as 3 decades (Hanes 1971, Zedler et al. 1983, Riggan et al. 1988). Our data indicated that fire influenced structure of sand shinnery oak communities by reducing the stature, visual obstruction, and canopy coverage of shrubs. Vegetation structure of sand shinnery oak communities was highly resilient, recovering in $2-4$ growing seasons after a fire. Shrub species composition was unaffected by fires. Two fires, 2 
growing seasons apart, had less effect on vegetation structure than the initial fire.

Response to disturbance of shrubland and forest communities may be determined by variable life history traits of dominant species (Noble and Slayter 1980). Species utilizing vegetative regrowth after fire regenerate more rapidly than those that reproduce primarily by seed (Hobbs et al. 1984). Typically, species that have the ability to propagate through vegetative means allocate large amounts of resources to root systems to survive and resprout following fire damage, while species that reproduce primarily by seed rely on postfire dispersal, germination, seedling growth, and succession to recover from disturbances (Hodgkinson 1998). Shrub communities in which reproduction by seed plays a large role in recruitment may therefore be susceptible to long-term change in composition and structure following disturbance (Tyler 1996).

In contrast, sand shinnery oak reproduces almost entirely through vegetative means with sprouts arising from underground rhizomes, and only produces seed about 2 of 5 years (Cook 1985, Peterson and Boyd 1998). Germination and establishment of sand shinnery oak has not been reported under field conditions (Dhillion et al. 1994, Peterson and Boyd 1998). Aboveground biomass of sand shinnery oak is resilient following fire by resprouting rapidly from rhizomes (McIlvain and Armstrong 1966, Boyd 1999). At a height of $0.3-1.5 \mathrm{~m}$ and consisting of clones as old as several thousand years, shinnery oak has the greatest ratio of underground to aboveground tissue of all American shrubs with estimates from 10:1 to $16: 1$ (Pettit 1986). The capacity of sand shinnery oak to recover rapidly following a fire should be expected because of its massive underground root system.

Our data suggested that recovery of sand shinnery oak structure is more rapid after 2 burns than after a single fire. This is contrary to what was expected, considering past literature suggested that multiple fires may create more open habitat in shrubland communities (Scifres and Hamiliton 1993). This likely resulted from a lack of adequate fine fuel available for a successful fire at the time of the second burn, resulting in lower fire intensity and lower woody plant mortality (Savage and Swetnam 1990, Fuhlendorf and Smeins 1997). Oak leaf litter is often the primary fine fuel available for successful fires in sand shinnery oak communities (Peterson and Boyd 1998), and our data indicated that at least 4 growing seasons is needed for accumulation of litter to attain preburn levels. Rapid recovery of structure $(<3$ years), and the ineffectiveness of frequent fires due to slow fuel accumulation suggest that restoration of stable or long-term open structure in sand shinnery oak communities through the use of prescribed fire would be difficult.

Historically, fire was assumed to be the dominant disturbance in sand shinnery oak communities responsible for reducing the stature and dominance of shrubs across the landscape. Reintroduction of fire into these communities after 100 years or more without this disturbance did not cause long-term changes (> 3 years) in vegetation structure and composition. Frequent fires $(<3$ year return interval) would be required to maintain herbaceous dominance in these communities, yet more frequent fires are not possible due to limited fine fuel accumulation during the fire interval. This suggests that attempts to restore herbaceous dominance in this shrubland community by mimicking historic fire regimes may have limited success. It is not clear whether these limitations are caused by a misinterpretation of historical fire regimes, ecological thresholds associated with over 100 years of altered fire regimes, or interactive influences of other factors, such as climate or livestock grazing (Fuhlendorf 1999). Regardless of the historical role of fire, current prescribed fires temporarily alter the vegetation structure of sand shinnery oak communities, and can be an integral part of a vegetation management plan that recognizes the uniqueness of shrublands within the Great Plains.

\section{Literature Cited}

Axelrod, D. I. 1985. Rise of the grassland biome, central North America. Bot. Rev. 51:163-201.

Bailey, J. and C. Painter. 1994. What good is this lizard? N M. Wildl. 39(4):22-23.

Bonham, C. D. 1989. Measurements for terrestrial vegetation. John Wiley and Sons, Inc. New York, N.Y.

Boyd, C. S. 1999. The effects of burning season and frequency on the vegetative character and insect abundance of Sand Shinnery Oak range in western Oklahoma. PhD. Thesis, Oklahoma State Univ. Stillwater, Okla.

Burgess, D. L, J. D. Nichols, and O. G. Henson. 1963. Soil Survey of Roger Mills County, Oklahoma. Washington, DC: USDA SCS.
Conner, N.R., H.W. Hyde, and H.R. Stoner. 1974. Soil Survey of Andrews County, Texas. Washington, DC: USDA SCS.

Cook, R.E. 1985. Growth and development in clonal plant populations. pp. 259-296. In: J. B. C. Jackson, L. W. Buss, and R. E. Cook (eds), Population biology and evolution of clonal organisms. Yale Univ. press, New Haven, Conn.

Dhillion, S.S. and M.H. Mills. 1999. The sand shinnery oak (Quercus havardii) communities of the Llano Estacado: history, structure, ecology, and restoration. pp. 262-274. In: R. C. Anderson, J. S. Fralish, and J. M. Baskin (eds.), Savannas, barrens, and rock outcrop plant communities of North America. Cambridge Univ. Press, Cambridge, Mass.

Dhillion, S.S., M.A. McGinley, C.F. Friese, and J.C. Zak. 1994. Construction of sand shinnery oak communities of the Llano Estacado: animal disturbances, plant community structure, and restoration. Rest. Ecol. 2:51-60.

Ffolliot, P.F. and D.A. Bennett. 1996. Peak fire of 1988, its effect on Madrean oak trees. pp. 235-237. In: Effects of fire on Madrean province ecosystems. U. S. Forest Serv. Gen. Tech. Rep. \#RM-GTR-289. Rocky Mt. Forest and Range Exp. Sta., Fort Collins, Colo.

Fuhlendorf, S.D. 1999. Ecological considerations for woody plant management. Rangelands 21:12-15.

Fuhlendorf, S.D. and F.E. Smeins. 1997. Long-term vegetation dynamics mediated by herbivores, weather and fire in a JuniperusQuercus savanna. J. Veg. Sci. 8:819-828.

Gross, F.A. and W.A. Dick-Peddie. 1979. A map of primeval vegetation in New Mexico. Southwestern Natur. 24: 115-122.

Guthery, F.S., T.B. Doer, and M.A. Taylor. 1981. Use of a profile board in sand shinnery oak communities. J. Range Manage. 34:157-158.

Hanes, T.L. 1971. Succession after fire in the chaparral of southern California. Ecol. Monogr. 41:27-52.

Hatch, S.L., K.N. Gandhi, and L.E. Brown. 1990. Checklist of the Vascular Plants of Texas. Texas Agr. Exp. Sta. MP-1655, College Station, Tex.

Hobbs, R.J., A.U. Mallik, and C.H. Gimingham. 1984. Studies on fire in scottish heathland communities: III vital attributes of the species. J. Ecol. 72: 963-976.

Hodgkinson, K.C. 1998. Sprouting success of shrubs after fire: height-dependent relationships for different strategies. Oecologia 115:64-72.

Hodson, M.V., T.E. Calhoun, C.L. Chastain, L.W. Hacker, W.G. Henderson, and C.R. Seagraves. 1980. Soil Survey of Chaves County, New Mexico, southern part. Washington, DC: USDA SCS. 
Kopp, S.D., F.S. Guthery, N.D. Forrester, and W. E. Cohen. 1998. Habitat selection modeling for Northern Bobwhites on subtropical rangeland. J. Wildl. Manage. 62:884-902.

Marcy, R.B. 1854. Explorations of the Red River of Louisiana in the year 1852. $33^{\text {rd }}$ Congress, $1^{\text {st }}$ Session, House Exec. Doc. Washington: A.O.P. Nicholson. pp. 24-25.

McIlvain, E.H. and C.G. Armstrong. 1966. A summary of fire and forage research on shinnery oak rangelands. Proc. Tall Timbers Fire Ecol. Conf. 5:127-129.

Noble, I.R. and R.O. Slayter. 1980. The use of vital attributes to predict succession changes in plant communities subject to recurrent disturbances. Vegetatio 43:5-21.

Nudds, T.D. 1977. Quantifying the vegetative structure of wildlife cover. Wildl. Soc. Bull. 5:113-117.
Peterson, R.S. and C.S. Boyd. 1998. Ecology and management of sand shinnery oak communities: A literature review. U. S. Forest Serv. Gen. Tech. Report \#GTR-16. Rocky Mt. Forest and Range Exp. Sta., Fort Collins, Colo.

Pettit, R.D. 1986. Sand shinnery oak. Control and management. Management note 8 . Lubbock: Texas Tech Univ., Range and Wildl Manage., Lubbock, Tex.

Riggan, P.J., S. Goode, P.M. Jacks, and R. N. Lockwood. 1988. Interaction of fire and community development in chaparral of southern California. Ecol. Monogr. 58:155-176.

SAS Institute Inc. 1988. SAS procedures guide, release 6.03 edition. Cary, N. C.: SAS Institute, Inc.

Savage, M. and T.W. Swetnam. 1990. Early $19^{\text {th }}$-century fire decline following sheep pasturing in a Navajo ponderosa pine forest. Ecol. 71:2374-2378.
Scifres, C.J. and W.T. Hamiliton. 1993. Prescribed burning for brushland management: the south Texas example. Texas A\&M Univ. Press, College Station, Tex.

Stroup, W.W. and J. Stubbendieck. 1983. Multivariate statistical methods to determine changes in botanical composition. J. Range Manage. 36:208-212.

Tyler, C.M. 1996. Relative importance of factors contributing to postfire seedling establishment in maritime chaparral. Ecol. 77:2182-2195.

Zedler, P.H., C.R. Gautier, and G.S. McMaster. 1983. Vegetation change in response to extreme events: the effect of a short interval between fires in California chaparral and coastal scrub. Ecol. 64:809-818. 


\title{
Juniper encroachment into aspen in the Northwest Great Basin
}

\author{
TRAVIS G. WALL, RICHARD F. MILLER, AND TONY J. SVEJCAR
}

Authors are research associate, professor of Rangeland Resources Oregon State University, and supervisory rangeland scientist, USDA-ARS. All are located at the Eastern Oregon Agricultural Research Center, 67826-A Hwy 205, Burns, Ore. Author is currently an instructor at BYU Idaho, Rexburg, ID

\begin{abstract}
In the northwest Great Basin, western juniper (Juniperus occidentalis subsp. occidentalis Hook.) is encroaching into aspen (Populus tremuloides Michx.) communities. There is a concern that aspen communities in this region are in a state of decline, but their status has not been documented. This study determined the timing, extent, and some of the effects of this expansion. Ninety-one aspen stands were sampled for density, canopy cover, age, stand structure, and recruitment of western juniper and aspen. Soils and tree litter beneath aspen and western juniper were collected to analyze the effects of western juniper on soils. Additionally, 2 large aspen complexes in southeast Oregon were intensively aged to determine disturbance (fire) frequencies. Western juniper encroachment peaked between 1900 and 1939 with $77 \%$ of all juniper trees sampled having been established during this period. Three-fourths of aspen stands sampled have established populations of western juniper. Twelve percent of aspen stands sampled were completely replaced by western juniper and another $23 \%$ dominated by western juniper. Average density of western juniper in aspen sites was 1,573 trees $\mathrm{ha}^{-1}$. Seventy percent of aspen stands sampled had zero recruitment of new aspen. Aspen stands averaged 98 years old. There was an inverse correlation between aspen canopy cover and western juniper canopy cover. Soils influenced by western juniper had a higher $\mathrm{C}: \mathrm{N}$ ratio, $\mathrm{pH}$, salts, lime, and sulfate, and lower amounts of magnesium, iron, copper, and manganese. Aspen litter had a lower $\mathrm{C}: \mathrm{N}$ ratio than western juniper litter. Two major aspen complexes sampled had even-age, 2-tiered even-age, and multiple-age aspen trees. The absence of presettlement juniper within all sampled aspen stands suggests fire was the primary stand-replacing disturbance in these northwest Great Basin aspen communities. The lack of fire coupled with aspen stand decadence and low recruitment levels will allow for the continued encroachment and replacement of aspen communities by western juniper in the northwest Great Basin.
\end{abstract}

Key Words: Juniperus occidentalis subsp. occidentalis, Populus tremuloides, succession, age structure, disturbance.

The Eastern Oregon Agricultural Research Center (EOARC), and Bureau of Land Management Districts Burns Ore, Lakeview Ore, and the Alturas Calif area office supported this research. The Oregon State University Agricultural Experiment Station and USDA Agricultural Research Service jointly operate EOARC. The authors wish to thank Dale Bartos, Lee Eddleman, Charles Kay, Bill Romme, and 2 anonymous reviewers for their constructive comments.

Oregon State Agricultural Experiment Station Technical Paper Number 11738.

Manuscript accepted 14 Jan. 01.

\section{Resumen}

En la Gran Cuenca del noroeste el "Western juniper" (Juniperus occidentalis subsp. occidentalis Hook.) esta invadiendo las comunidades de "Aspen" (Populus tremuloides Michx.). Existe una preocupación respecto a si las comunidades de "Aspen" de esta región están en un estado de deterioro, pero este punto no ha sido documentado. Este estudio determinó la época, cantidad y algunos efectos de esta expansión. Se muestrearon 91 poblaciones de "Aspen" en las cuales se midió la densidad, cobertura de la copa, edad, estructura de la población y establecimiento de "Western juniper" y "Aspen". Bajo los árboles de "Aspen" y "Western juniper" se colectó suelo y mantillo de árboles para analizar los efectos del "Western juniper" en los suelos. Adicionalmente 2 grandes complejos de "Aspen" situados en el sudeste de Oregon fueron intensivamente muestreados para conocer su edad y determinar las frecuencias de disturbio (fuego). La invasión de "Western juniper" alcanzó su pico entre 1900 y 1939, periodo en el cual se estableció el $77 \%$ de los árboles de "Juniper" muestreados. En el $\mathbf{7 5 \%}$ de las poblaciones de "Aspen" muestreadas se habían establecido poblaciones de "Western juniper". El $12 \%$ de estas poblaciones de "Aspen" fueron completamente remplazadas por "Western juniper" $y$ otro $23 \%$ fue dominado por "Western juniper". La densidad promedio de "Western juniper" en los sitos de "Aspen" fue de 1,573 árboles $\mathrm{ha}^{-1}$. El $70 \%$ de las poblaciones de "Aspen" muestreadas no presentaron establecimiento de nuevas plantas de esta especie. Las poblaciones de "Aspen" promediaron una edad de 98 años. Hubo una correlación inversa entre la cobertura de copa del "Aspen" y la cobertura de copa del "Western juniper". Los suelos influenciados por "Western juniper" tuvieron valores mas altos en la relación $\mathrm{C}: \mathrm{N}$, $\mathrm{pH}$, sales, cal y sulfato y por otra parte tuvieron menores cantidades de magnesio, fierro, cobre y manganeso. El mantillo de "Aspen" tuvo una menor relación C:N que el mantillo de "Western juniper". Los dos complejos principales de "Aspen" que se evaluaron tuvieron una edad uniforme, 2 estratos de edad uniforme y árboles de "Aspen" de edad múltiple. Todas las poblaciones de "Aspen" estudiadas presentaron ausencia de "Juniper" antes de la de colonización, lo que sugiere que el fuego fue el principal factor de remplazo de las poblaciones de especies en estas comunidades de "Aspen de la Gran Cuenca del noroeste. La falta de fuego acompañada de la decadencia de la población de "Aspen" y sus bajos niveles de establecimiento permitirán que en la Gran Cuenca del noreste ocurra una invasión continua y el remplazo de las comunidades de "Aspen" por comunidades de "Western juniper". 
Quaking aspen (Populus tremuloides Michx. $)^{1}$ communities are on the decline throughout the western United States (Bartos and Campbell 1998a, Miller and Rose 1995). Encroachment of conifers has contributed to a $60 \%$ decline in aspen dominated landscapes on national forests across Utah (Bartos and Campbell 1998a). Although a considerable amount of work has been conducted in the Rocky Mountain region, little has been done to evaluate the status of aspen in the northwest Great Basin (northwest Nevada, northeast California, and southeast Oregon). Miller and Rose (1995) reported that western juniper (Juniperus occidentalis var. occidentalis Hook.) was actively encroaching into aspen stands on Steens Mountain, Oregon, below $2120 \mathrm{~m}$. However, neither the status of stand structure and age of aspen communities are known for the northwest Great Basin nor the extent of juniper invasion into these stands.

Although aspen communities constitute a small portion of the semi-arid northwest Great Basin, they add diversity to landscapes that are predominately sagebrush (Artemisia sp.) and juniper. In southeastern Oregon, 84 wildlife species reproduce and 110 wildlife species forage within aspen/grass communities and 95 wildlife species reproduce and 117 wildlife species forage within aspen/mountain big sagebrush (Artemisia tridentata subsp. vaseyana Beetle, Rhodora $)^{1}$ communities (Maser et al. 1984). Aspen communities are also very productive in terms of herbaceous plant growth and species diversity. Aspen are generally recognized as having more lush undergrowth than neighboring coniferous forests (Mueggler 1985). The herbaceous vegetation occurs as a multilayered mixture of shrubs, forbs, and grasses and consists of a broad combination of over 300 species (Houston 1954). Bartos and Campbell (1998b), state that when conifers overtake aspen communities, less water is available to the watershed, biomass of understory vegetation is significantly reduced, and the diversity of wildlife and plant species declines. The greatest concern is the loss of aspen once a conifer community becomes established because aspen does not readily establish from seed (McDonough 1985, Mitton and Grant 1996).

The goals of this study were to: (1) assess the extent and timing of western juniper encroachment into aspen communities; (2) evaluate aspen stand structure, age structure, and determine pre- and post-

${ }^{1}$ Nomenclature is from Cronquist et al. (1972) settlement disturbance intervals; and (3) determine if western juniper alters soils previously occupied by aspen in the northwest Great Basin.

\section{Methods}

\section{Site Description}

The study was located in the High Desert and Klamath Ecological Provinces (Cronquist et al. 1972, Bailey 1994, Anderson et al. 1998) in southeast Oregon, northeast California, and northwest Nevada (latitudes $40^{\circ} 55^{\prime}$ to $43^{\circ} 00^{\prime}$ and longitudes $118^{\circ} 30^{\prime}$ to $120^{\circ} 45^{\prime}$ ) (Fig.1). Desert basins, uplands, canyons, and fault block mountains typify the geography of these 2 provinces. Shrub-grass communities associated with aspen are predominantly mountain big sagebrush with various degrees of low sagebrush (Artemisia arbuscula Nutt.), rabbitbrush (Chrysothamnus sp. Nutt.), bitterbrush (Purshia tridentata (Pursh) DC.) and snowberry (Symphoricarpos oreophilus A. Gray) with fescues (Festuca sp. L.), wheatgrasses (Agropyron sp. Gaertn.), and needlegrasses (Stipa sp. L.). Tree communities include western juniper, mountain mahogany (Cercocarpus ledifolius Nutt.), and aspen. Climate is cool and semi-arid characterized by cold wet winters and hot dry summers. Precipitation falls primarily as snow in November, December, and January and as rain in March through June.

Aspen stands in the shrub steppe frequently occupy sites along the north and northeast base of ridges where snow drifting increases available moisture enabling these areas to sustain aspen in an otherwise semi-arid environment. Aspen stands studied varied in elevation from a high of $2,120 \mathrm{~m}$ to a low of $1,494 \mathrm{~m}$. Within this elevation, yearly precipitation varies from 30 to $40 \mathrm{~cm}$.

Aspen stands can be complex with several layers of shrubs, tall forbs, low forbs, grasses, and annuals. In contrast, stands can also be very simple with even-aged aspen and a general assembly of grasses. Shrub genera typically found within aspen stands include: Symphoricarpos Duhamel., Rosa L., Amelanchier Medik., Prunus L., and Berberis L. Forb genera include: Thalictrum L., Osmorhiza Raf., Geranium L., Aster L., Lathyrus L., Achillea L., Galium L., and Senecio L. Graminoid genera include: Agropyron Gaertn., Bromus L., Elymus L., Poa L., and Carex L. Soils that characterize these semi-arid aspen stands were formed from igneous rock (basalt) and are typically loamy to sandy loam mixed frigid Pachic Haploxerolls, > $1 \mathrm{~m}$ in depth.

\section{Stand Selection and Plot Layout}

We made a general search for aspen stands $>0.5$ ha in the High Desert and Klamath Ecological Provinces. We also contacted the local federal land management agencies for known locations of aspen stands. We sampled all upland stands within the western juniper belt, $<2,120 \mathrm{~m}$ in elevation that could be found. In each stand

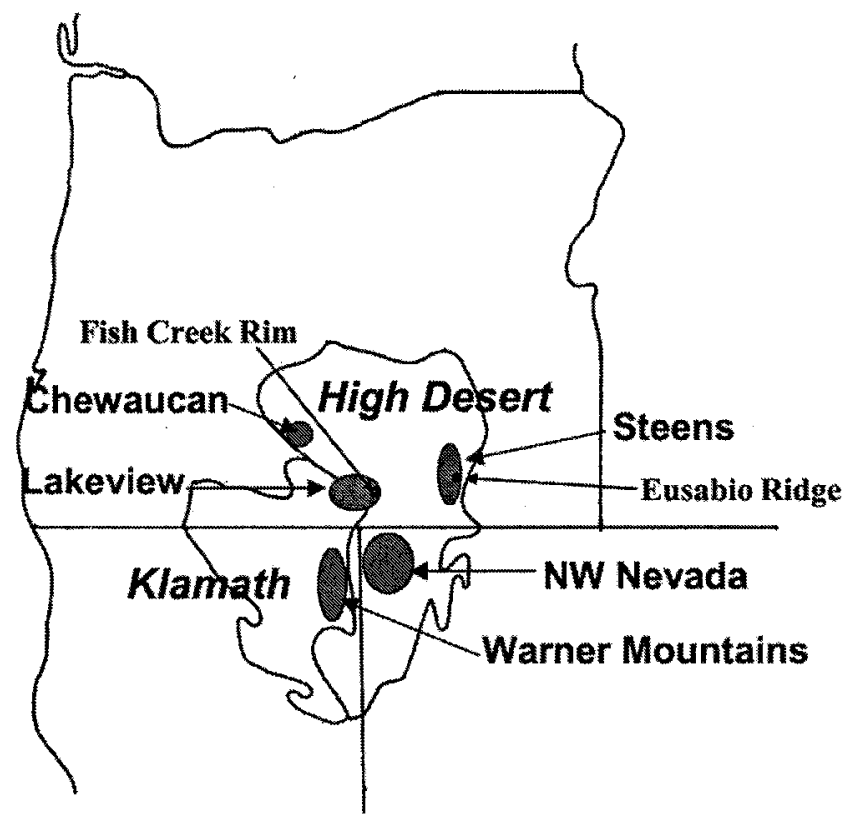

Fig. 1. General locations of aspen stands sampled across the High Desert and Klamath Ecological Provinces. 
sampled, a circular plot $15 \mathrm{~m}$ in diameter was positioned entirely within the aspen community. In stands greater than 1 ha, several circular plots were randomly placed to characterize the community. A total of 91 aspen stands were sampled.

\section{Stand Data Collection}

Within each $15 \mathrm{~m}$ circular plot all live and dead stems of juniper and aspen were counted and assigned to a height class. Adult aspen were defined as trees equal to or greater than $75 \%$ of stand height. Aspen trees considered to have potential for recruitment were equal to or greater than 2 $\mathrm{m}$ tall up to $75 \%$ of stand height. Trees less than $2 \mathrm{~m}$ in height were typically browsed, so recruitment potential for this height class was assumed to be very limited.

In every stand sampled, 5 of the largest aspen and 5 of the largest western juniper based on height and stem diameter (assumed to potentially be the oldest) were measured for height, diameter, and sampled with an increment corer. This was to establish the age of the dominant aspen trees and approximate time of initial juniper encroachment. Trees that were too small to core were cut at ground level to obtain a cross-section slab. Aspen cores and slabs were stained with phloroglucinol, sanded, and then aged by counting growth rings under a dissecting microscope. Phloroglucinol helped distinguish the very faint annual rings in the sapwood.

To determine if aspen community characteristics influence juniper encroachment, aspen and juniper canopy cover, canopy height, stand age, aspect, slope, and elevation data were collected. A spherical densiometer was used to measure overstory canopy cover for aspen and western juniper within the $15 \mathrm{~m}$ circular plot. Tree height was determined by measuring length of dead fallen trees in combination with visual estimates of live trees. Aspect, slope, elevation, estimated percent herbaceous cover, and estimated percent bare ground were recorded for each site sampled. With this information, statistical correlations were computed between juniper canopy cover and density versus aspen overstory canopy cover, canopy cover height, stand age, aspect, slope, elevation, percent herbaceous cover, and percent bare ground.

\section{Disturbance Interval}

To determine disturbance intervals in aspen within the northwest Great Basin, 2 sites with the largest stands were sampled. The first, a continuous 71 ha stand, is located along Eusabio Ridge and Ankle
Creek on the southern end of Steens Mountain southwest of Burns, Ore. The second, a series of adjacent stands totaling approximately 35 ha was located on Fish Creek Rim north of Adel, Ore.

The Eusabio stand was systematically sampled by walking several transects from toe-slope to the ridge crest. Transects were placed every 80 to 100 meters across the length of the $3 \mathrm{~km}$ long stand. Along these transects, plots were established every 25 to $50 \mathrm{~m}$. The variation in distance between plots was determined by stand structure; i.e., plots were centered in sites with similar tree density and tree size and not placed to overlap areas of varying stand structure. The broad distribution of plot locations captured the variability of aspect, elevation, and slope within the stand. Within each plot, increment cores were collected from the 10 largest aspen trees to determine age distributions within the stand. Within the 71 ha stand on Eusabio Ridge, a total of 100 plots and 1,000 aspen were sampled.

The series of stands located on Fish Creek Rim were situated along a northwest to southeast set of ridges approximately 11 kilometers long. Starting at the northwest end and working southeast, each individual aspen stand was sampled. Similarly, the 10 largest aspen trees cored to determine age within each plot. A total of 28 plots with 280 aspen were sampled over approximately 35 ha.

All 1,280 aspen cores were stained (with phloroglucinol), sanded, and aged by ring counts. Because aspen sprouts after disturbance, the oldest trees in each of the 128 plots revealed the approximate timing of the last major disturbance within each of the plots. The large number of plots allowed us to construct a stand disturbance history for the 2 stands. A pre-Euro American settlement (pre-1870) mean and range of years between disturbances were calculated for each aspen complex sampled.

\section{Soil}

Soils were sampled using a randomized block design with 5 blocks. These 5 blocks were placed in aspen stands greater than 1.5 ha growing on Steens Mountain. Block size depended on aspen stand characteristics, such as distance between treatments and shape of aspen stands. Each block had the following 2 treatments:

1. Soils influenced by aspen.

2. Soils once influenced by aspen but now dominated and influenced by western juniper.

Five sub-samples were collected 2 thirds inward from the drip line of the present dominant canopy in each treatment. The top $10 \mathrm{~cm}$ of soil was sampled with a hand shovel, collecting approximately 500 g per sample. A total of 10 soil sub-samples were collected in each block with 50 total sub-samples for the 5 blocks $(n=25$ for each treatment). The soil sub-samples were sent to a soils lab where standard techniques were used to analyze for $\mathrm{C}: \mathrm{N}$ ratio, $\mathrm{pH}, \mathrm{CEC}, \%$ lime, \%OM, and plant available $\mathrm{C}, \mathrm{N}, \mathrm{P}, \mathrm{K}, \mathrm{Ca}, \mathrm{Mg}, \mathrm{Na}, \mathrm{Zn}, \mathrm{Fe}$, $\mathrm{Mn}, \mathrm{Cu}, \mathrm{B}$, and sulfate. Additionally, at each soil sub-sample collection site for juniper-dominated treatments, juniper were cored and aged to determine duration of their influence over the site sampled.

At each sub-sample collection site, resident litter depth was measured $(n=50$ across the 5 blocks). A litter trap approximately $40 \times 90 \mathrm{~cm}$ was placed under each treatment in all 5 blocks. These traps captured current litter fall from 1 August to 1 November 1998. The 2 litter types (aspen and western juniper) were analyzed with a CHN analyzer (Perkin Elmer 2400 Series II, Norwalk, CT $)^{2}$ to determine differences in carbon and nitrogen content and $\mathrm{C}: \mathrm{N}$ ratios.

\section{Data Analysis}

The statistical package SAS was used for all data analysis (SAS Institute 1990). Stepwise multiple regression was used to determine if aspen overstory canopy cover, canopy cover height, stand age, aspect, slope, and elevation affected western juniper canopy cover and density. Soil data were analyzed as a randomized block with 2 treatments. ANOVA's were calculated to determine if soil and litter variables differed between the 2 treatments.

\section{Results}

\section{Western juniper encroachment.}

Western juniper encroachment into aspen stands has occurred throughout the shrub steppe region in southeast Oregon, northwest California and northwest Nevada. Of the 91 aspen stands sampled, $86(95 \%)$ contained western juniper. Twelve percent of the stands sampled were completely replaced by western juniper. In another $23 \%$ of stands, western juniper was the dominant tree canopy. Western juniper was common but not yet dominant in $42 \%$, present but not common in $18 \%$, and absent in $5 \%$ of the aspen stands sampled. The average density of

${ }^{2}$ Mention of a trade name does not indicate endorsement by USDA or Oregon State University. 


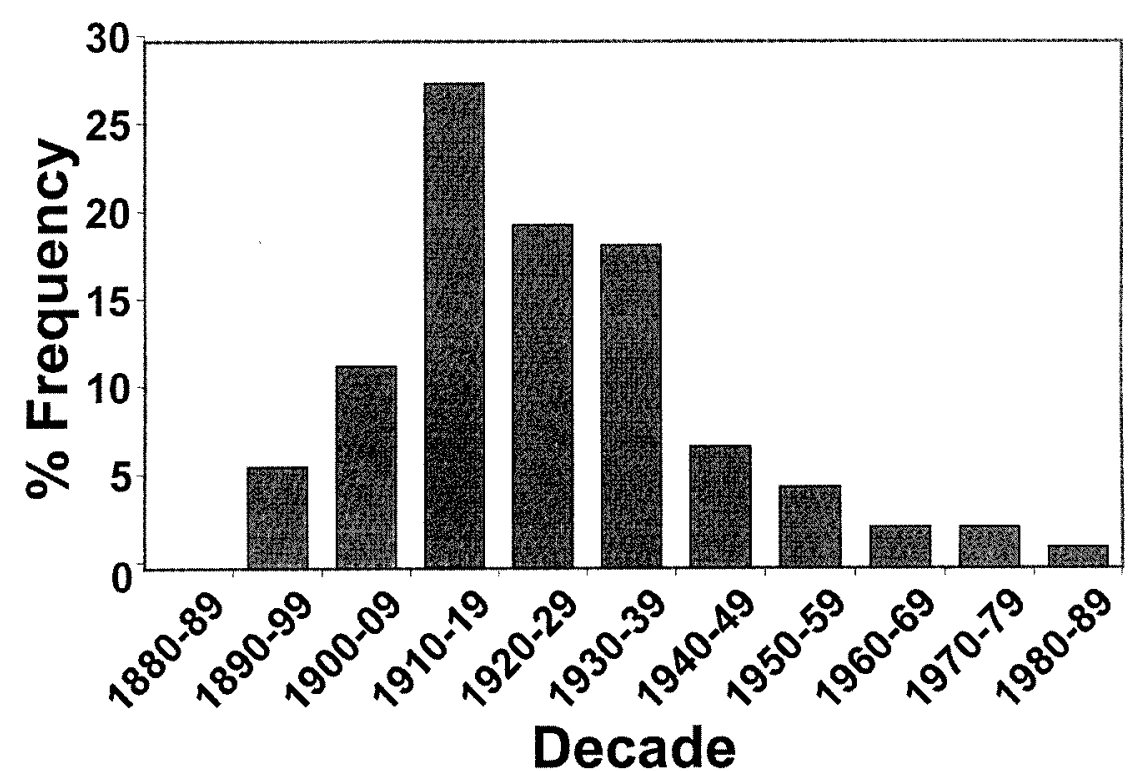

Fig. 2. Decade when juniper initially became established into aspen communities across the northwestern Great Basin.

western juniper was 1,573 trees $\mathrm{ha}^{-1}$ of aspen sampled ( $\mathrm{SE}=133.7)$.

Western juniper canopy cover averaged $21 \%(\mathrm{SE}=2.5)$ across the 86 aspen communities containing juniper. Based on percent composition between western juniper cover and aspen cover, western juniper constitutes $27 \%$ of the total overstory canopy cover in aspen stands across the study area.

Western juniper encroachment into aspen peaked between 1900 and 1939 with $77 \%$ of all trees sampled establishing during this 39-year period (Fig. 2). The average age of western juniper was 72 years old (standard error $=2.0$ ). Only $5 \%$ were greater than 100 years old and none exceeded 107 years.

\section{Aspen stand structure.}

Aspen stands averaged 98 years old ( standard error $=3.2$ ) with $85 \%$ of the stands falling between 70 and 130 years old. Forty-eight percent of the aspen stands were greater than 100 years old.

Mean density of mature live aspen trees in stands sampled was 953 trees ha-1 $(\mathrm{SE}=$ 88.1). Aspen stand density of adult dead trees averaged 123 trees $^{-1} \mathrm{~h}^{-1}$ (standard error $=18.9$ ). Where recruitment trees occurred, they averaged 143 trees $\mathrm{ha}^{-1}(\mathrm{SE}=50.1)$. However, $70 \%$ of aspen stands sampled had 0 recruitment. Aspen canopy cover averaged $59 \%$ and total tree cover, aspen and juniper, averaged $73 \%(\mathrm{SE}=3.0)$.

\section{Variables affecting western juniper encroachment.}

Several variables were significantly $(\mathrm{p}<$ .05 ) related to western juniper encroachment (Table 1). Western juniper and aspen cover expressed the strongest relationship. As aspen cover decreased western juniper cover increased. Other parameters reportindicated they explained only a small degree of the variability. Elevation and aspect are the 2 site variables that were significantly correlated to western juniper cover. As elevation increased western juniper cover decreased. East and southeast facing aspen stands contained higher densities of juniper than north and northeast facing stands.

Simple regression revealed that as juniper cover increased in aspen stands, herbaceous plant cover decreased and bare ground increased. ed were significant but their $\mathrm{R}^{2}$ values

\section{Disturbance}

Mean ages of dominant aspen canopy trees tended to cluster around several establishment periods across the 2 large aspen stands suggesting portions of these stands had been disturbed at different time periods. Within the 71 ha Eusabio/Ankle Creek aspen complex, 52 out of 100 (52\%) plots were $73-80$ years old (Fig. 3) each with an age spread of less than 10 years. Another 17 plots were even-aged ranging from 119-132 years. The remaining 31 plots had a spread of ages greater than 10 years. However, these 31 plots did have even-aged components. For example, a plot could have had 8 trees 128 years old and 2 trees 112 years old. Another plot may have had 3 trees 160 years old and 7 trees 100 years old. In none of the plots did the 10 largest trees represent more than 2 age classes.

Within the Fish Creek/Cox Springs aspen complex 2, of 28 plots were 62-64 years old, 3 plots were 95-96 years old, 3 plots were 117-119 years old, and 3 plots were 124-128 years old (Fig. 4). On 9 plots, a 2-tiered even-aged class occurred. The remaining 8 plots had no pattern at all and consisted of several ages.

$\begin{aligned} & \text { Table 1. Multiple Regression relationships between aspen, western juniper, and geography vari- } \\
& \text { ables. }\end{aligned}$
\begin{tabular}{lcc} 
& $\mathrm{R}^{2}$ & p-value \\
\hline \hline Variables & .80 & .0001 \\
Juniper cover vs. aspen cover & .19 & .0001 \\
Juniper cover vs. aspen density & .13 & .0004 \\
Juniper cover vs. elevation & .10 & .0018 \\
Juniper cover vs. bare ground & .18 & .0001 \\
Juniper cover vs. herbaceous cover & .04 & .0365 \\
Juniper density vs. aspect & .04 & .0313 \\
Juniper density vs. aspen cover & .06 & .0187 \\
Juniper density vs. aspen density & .32 & .0001 \\
Aspen age vs. aspen cover &
\end{tabular}

\section{Effects of western juniper on soil.}

Western juniper varied from 75 to 85 years old across the soil plots located on Steens Mountain. Average juniper litter depth across the juniper influenced plots was $10 \mathrm{~cm}( \pm 2 \mathrm{~cm})$. The average litter depth for aspen influenced soils was $3 \mathrm{~cm}$ $( \pm 1 \mathrm{~cm})$.

There was no significant difference in soil carbon and nitrogen content between the 2 treatments. However, the $\mathrm{C}: \mathrm{N}$ ratio and $\mathrm{pH}$ proved to be significantly greater in the juniper than in aspen plots (Table 2). Soils influenced by western juniper also contained greater amounts of salts, lime, and sulfate, and lower amounts of magnesium, iron, manganese, and copper. The increase in $\mathrm{pH}$ beneath juniper may be 
Table 2. Mean, standard error, and p-value for different soil variables beneath the canopies of aspen and western juniper soil treatments.

\begin{tabular}{|c|c|c|c|c|c|}
\hline Variable & $\underset{\bar{X}}{\text { Aspen }}$ & SE & $\begin{array}{c}\text { Juniper } \\
\overline{\mathrm{X}}\end{array}$ & SE & p-value \\
\hline$\overline{\mathrm{C}: \mathrm{N} \text { ratio }}$ & 12.360 & 0.254 & 13.284 & 0.204 & 0.0102 \\
\hline $\mathrm{p}^{\mathrm{H}}$ & 6.800 & 0.042 & 7.380 & 0.043 & 0.001 \\
\hline Salts & 0.352 & 0.026 & 0.432 & 0.020 & 0.0190 \\
\hline CEC & 17.690 & 0.394 & 16.720 & 0.248 & 0.0036 \\
\hline$\%$ Lime & 0.620 & 0.044 & 0.820 & 0.049 & 0.0016 \\
\hline$\% \mathrm{OM}$ & 5.256 & 0.122 & 5.088 & 0.098 & 0.1918 \\
\hline $\mathrm{C} \mathrm{mg} \mathrm{kg}$ & 7.040 & 0.320 & 7.255 & 0.366 & 0.6500 \\
\hline $\mathrm{N} \mathrm{mg} \mathrm{kg}^{-1}$ & 0.568 & 0.022 & 0.542 & 0.022 & 0.3444 \\
\hline $\mathrm{P} \mathrm{mg} \mathrm{kg}^{-1}$ & 56.800 & 4.926 & 47.960 & 2.602 & 0.1168 \\
\hline $\mathrm{K} \mathrm{mg} \mathrm{kg}^{-1}$ & 549.560 & 25.373 & 536.880 & 38.254 & 0.6445 \\
\hline $\mathrm{Ca} \mathrm{mg} \mathrm{kg}^{-1}$ & 2786.400 & 110.027 & 2560.800 & 140.207 & 0.1032 \\
\hline $\mathrm{Mg} \mathrm{mg} \mathrm{kg}^{-1}$ & 245.080 & 2.064 & 228.040 & 6.592 & 0.0074 \\
\hline $\mathrm{Na} \mathrm{mg} \mathrm{kg}^{-1}$ & 86.080 & 5.660 & 79.160 & 5.429 & 0.2858 \\
\hline $\mathrm{Zn} \mathrm{mg} \mathrm{kg}^{-1}$ & 3.448 & 0.386 & 3.712 & 0.624 & 0.6396 \\
\hline $\mathrm{Fe} \mathrm{mg} \mathrm{kg}{ }^{-1}$ & 29.016 & 3.060 & 13.936 & 0.539 & 0.0001 \\
\hline Mn mg kg ${ }^{-1}$ & 5.920 & 0.622 & 2.980 & 0.221 & 0.0001 \\
\hline $\mathrm{Cu} \mathrm{mg} \mathrm{kg}{ }^{-1}$ & 0.524 & 0.040 & 0.408 & 0.030 & 0.0071 \\
\hline $\mathrm{B} \mathrm{mg} \mathrm{kg}{ }^{-1}$ & 0.364 & 0.015 & 0.344 & 0.015 & 0.2261 \\
\hline Sulfate $\mathrm{mg} \mathrm{kg}^{-1}$ & 5.280 & 0.212 & 6.720 & 0.464 & 0.0029 \\
\hline
\end{tabular}

partially attributed to the increase in lime. Bates et al. (2002) also reported increases in soil $\mathrm{pH}$ beneath western juniper canopies compared to tree interspaces. Nutrient composition for aspen and juniper litter was also significantly different (Table 3). Carbon and nitrogen content were greater and $\mathrm{C}: \mathrm{N}$ lower in aspen litter than in juniper litter.

\section{Discussion}

\section{Juniper Expansion}

Since the 1890 s, western juniper has been actively invading over $90 \%$ of aspen stands below 2,120 $\mathrm{m}$ in the northwest Great Basin. Across this geographic region, western juniper density in aspen sites typically exceeded 500 trees ha ${ }^{-1}$, with approximately one third of aspen stands sampled being replaced or dominated by western juniper.

Conifer expansion into aspen is widespread across the Western United States. In most instances, aspen is considered a seral species replaced by more shade tolerant conifers such as Douglas fir (Pseudotsuga menziesii Mirbel), Engelman spruce (Picea engelmanii Parry), and sub-alpine fir (Abies lasiocarpa Hook.) in the absence of disturbance (Mueggler 1985). Encroachment of these conifers has contributed to a $60 \%$ decline in aspen dominated landscapes on national forests across Utah (Bartos and Campbell 1998a). Although western juniper is a drought-adapted conifer, its with changes in fire return intervals, optimal climatic conditions for juniper seed production and establishment, and introduction of livestock (Miller and Wigand 1994, Miller and Rose 1995, 1999).

\section{Disturbance}

Fire has been reported to be an important factor in facilitating the long-term presence and health of aspen across the landscape (Baker 1925, Bartos and Mueggler 1981, Jones and DeByle 1985, Brown and DeByle 1987, DeByle et al. 1989). European settlement has altered fire regimes through elimination of aboriginal burning, fire suppression, livestock grazing, introduction of exotic plant species, and urbanization of the West (Kay 1997, Miller et al. 1994, Miller and Rose 1999). Herbivory and lack of fire are likely key factors in the recent expansion of western juniper and lack of aspen recruitment in communities throughout the northwest Great Basin.

Age structure data from the Eusabio Ridge and Fish Creek Rim aspen complexes revealed 3 age structures: evenaged, 2-tiered even-aged, and multipleaged sites. Kay and Bartos (2000) concluded that excessive herbivory on aspen creates even-aged stands and aspen protected from herbivory become multipleaged stands. On the other hand, Jones and DeByle (1985) state that even-aged aspen stands result from a sprouting response after a fire and that multiple-aged stands result from a slow die-off of over-mature trees and the subsequent prolonged regeneration period.

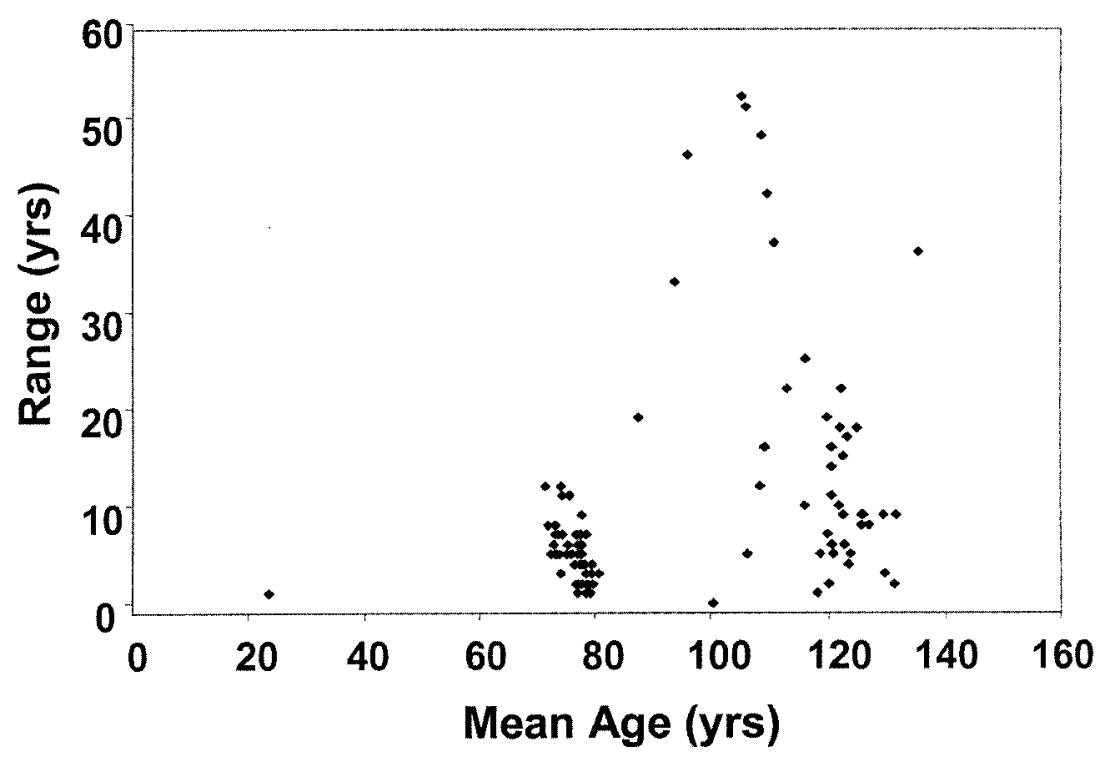

Fig. 3. Mean age and range of the10 largest overstory aspen trees in each plot in the Eusabio Ridge aspen complex. 
On Eusabio Ridge, $52 \%$ of the evenaged sites were about 80 years old, and $17 \%$ were about 125 years old (Fig. 4). Did fire or excessive herbivory or both create these even-aged sites? For the 2tiered, even-aged sites the age structure could have resulted from: 1) fire with some older surviving trees and a flush of regeneration, 2) fire with initial regeneration and then a secondary lag response of regeneration, or 3) brief lulls in herbivory pressure allowing new trees to establish. However, multiple-aged stands were lacking on Eusabio Ridge suggesting stand replacement disturbance events.

In the Fish Creek Rim aspen complex, even-aged sites of $60,95,118$, and 126 years old were found (Fig. 4). This suggests stand replacement disturbance occurring somewhere within the stand with a mean return interval of 16.5 years. In southern Colorado, fire had burned within a $77 \mathrm{~km}^{2}$ aspen stand nearly every decade between 1760 and 1870 (unpublished data, Romme et al.). Total stand replacement occurred about every 100 years. Fish Creek Rim may have experienced similar fire events. If aspen stand age structure on Fish Creek Rim had resulted from excessive herbivory, we would expect multiple aged tiers to be even aged across the stand. The data creates questions while the literature poses several potential interpretations.

Fire, disease, insects, herbivory, and natural mortality influence the age structure of aspen. Fire was a frequent disturbance process in adjacent mountain big sagebrush communities. Fire return intervals in the mountain big sagebrush alliance are typically 12 to 22 years, which limited western juniper encroachment (Miller and Rose 1999). In addition, the absence of presettlement juniper within all 91 aspen stands suggests fire was the primary stand-replacing disturbance in these northwest Great Basin aspen communities.

In the Chewaucan region of south-central Oregon, fire-scar data revealed fire return intervals ranged from 12 to 22 years prior to 1897 with the last major fire occurring in 1870 (Miller and Rose 1999). Hence, no recorded fire occurred in this area for a century. All aspen stands sampled in the Chewaucan region dated to the approximate time of the last largest fire in 1870. Although western juniper began establishing in the 1870 s in adjacent mountain sagebrush communities, encroacment into aspen did not occur until the mid 1890s. With the lack of fire for the past century, Chewaucan aspen stands linger in a state of decline. Established western juniper are on the brink of completely replacing these stands.

Long-term browsing of aspen regeneration by wild and domestic ungulates may limit aspen recruitment. Continuous or heavy grazing of aspen suckers jeopardizes the health, recruitment, and longevity of the stand (Bartos and Mueggler 1981, Bartos et al., 1991, DeByle 1985, Romme et al. 1995). If regenerating suckers are unable to overcome browsing pressure, then aspen stands cannot sustain

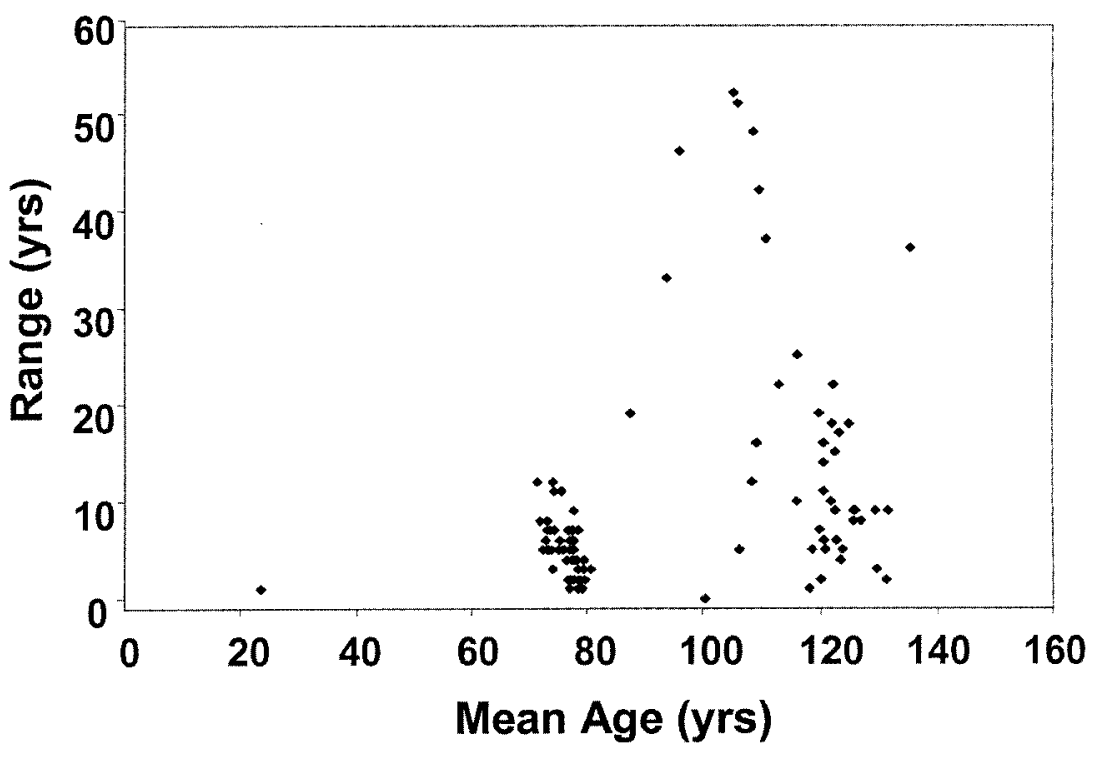

Fig. 4. Mean age and range of the10 largest overstory aspen trees in each plot in the Fish Creek Rim aspen complex. viable populations and persist amid the compounding effects of western juniper invasion and replacement. In our study, $70 \%$ of all aspen stands sampled had no active recruitment. The remaining $30 \%$ of aspen stands had active recruitment, but averaged only 143 juvenile trees ha ${ }^{-1}$. Mature or over-mature aspen stands with less than 1,235 suckers ha ${ }^{-1}$ may have regeneration problems and are at risk of being lost (Mueggler 1989, Bartos and Campbell 1998a). In essence, as adult aspen grow decadent and die in the northwest Great Basin, densities of juvenile aspen escaping from large ungulate use are not adequate to maintain the stand. We observed that terminal leader growth on most of the aspen suckers was absent due to browsing. Lack of regeneration due to excessive ungulate browsing of aspen suckers may allow western juniper to establish and accelerate succession to juniper woodlands. Reestablishment of aspen stands that are burned and subsequently sprout high densities of suckers may also be limited under heavy browsing pressure regardless of conifer encroachment (Bartos et al. 1994).

\section{Pattern of western juniper encroachment.}

The direct correlation between juniper and aspen canopy cover suggests strong interspecific competition between the 2 species. As aspen canopy cover decreased, juniper canopy cover increased ( $\mathrm{p}=$ .0001). Others have reported a significant negative correlation between juniper canopy cover with aspen canopy cover and density (Miller et al. 2000). Direct observation of juniper growth rings supports this competitive relationship. Beneath intact aspen canopies juniper growth rings were very tight, often with 30 to 40 rings $\mathrm{cm}^{-1}$. Within the same aspen stand individual juniper ring growth increased as much as $1 \mathrm{~cm} \mathrm{yr}^{-1}$ where mortality of aspen around the tree had opened the overhead canopy. Thus, aspen decadence may indirectly facilitate an increase in juniper growth. As aspen stands increase in age beyond 90 years, canopy cover declines $(\mathrm{p}=.0001)$. The fact that $75 \%$ of aspen stands sampled are greater than 90 years old suggests a decline in aspen canopy cover across the northwest Great Basin is likely occurring.

Several environmental factors also appear to influence the degree of juniper encroachment. Elevation had some effect on juniper canopy cover. As elevation increased, juniper canopy cover decreased. Since juniper are limited at upper eleva- 
Table 3. Mean, standard error, and p-value for carbon and nitrogen in litter collected beneath the canopies of aspen and western juniper.

\begin{tabular}{lccccc}
\hline \hline Variable & Aspen litter & SE & Juniper litter & SE & p-value \\
\hline C:N ratio & 45.310 & 7.191 & 76.637 & 4.458 & 0.0036 \\
$\%$ C & 51.036 & 0.81 & 48.802 & 0.503 & 0.0337 \\
$\% \mathrm{~N}$ & 1.228 & 0.163 & 0.646 & 0.040 & 0.0179 \\
\hline
\end{tabular}

tions by severe winter weather conditions and are not typically found above $2,120 \mathrm{~m}$, this correlation was expected (Miller et al. file data). Additionally, aspen stands that faced east or south-east had slightly higher densities of juniper than aspen stands that faced north or northeast. Slope and aspen height did not have any significant effects on western juniper densities or canopy cover. The relationship with elevation and aspect suggest juniper encroachment is more aggressive on the warmer sites. We would expect these sites to be more prone to fire. These correlations set forth geomorphic and biologic conditions that predispose a stand to juniper encroachment. These conditions are: 1) open aspen canopy cover $(<70 \%), 2)$ mature to overmature stands ( $>90$ years), 3) elevational location below $2,120 \mathrm{~m}, 4$ ) east or southeast facing stands.

Aspen stands with minimal juniper encroachment typically had over 3,000 aspen trees per ha and $>70 \%$ aspen canopy cover. Typically, herbaceous plant cover was $21 \%$. However, in stands where juniper was co-dominant to dominant in the overstory, aspen density was typically less than 1,425 tree/ha with a $20 \%$ aspen canopy cover and $11 \%$ herbaceous plant cover. Thus, understory vegetation in stands encroached upon by western juniper contrasted sharply with the lush, green understory in aspen dominated stands. Juniper encroached stands had higher amounts of bare ground and less herbaceous cover than non-invaded aspen.

\section{Effects on Soils}

Soils influenced by western juniper had a higher $\mathrm{C} / \mathrm{N}$ ratio and a higher $\mathrm{pH}$ than strictly aspen influenced soils (Table 2). This higher $\mathrm{C} / \mathrm{N}$ ratio can be attributed to the effect of western juniper litter on soils; juniper litter also has a higher $\mathrm{C} / \mathrm{N}$ ratio than aspen litter (Table 3).

Western juniper probably sequesters nutrients within the tree, not recycling them back into the soil as quickly as aspen. This difference is a result of the deciduous nature of aspen and the coniferous growth form of juniper. Other studies found that aspen leaf litter lost $42 \%$ of its weight during the first winter after leaf fall (Bartos and DeByle 1981). In comparison, western juniper needle litter on Steens Mountain lost only $17 \%$ of its mass over 2 years (Bates 1996). Aspen also shed approximately 1.4 times more leaf biomass annually than western juniper (Bartos and Debyle 1981, Bates 1996). Thus, aspen produces more litter, which decomposes faster than western juniper, resulting in a higher rate of nutrient cycling.

In addition to influencing soils, juniper encroachment may impact hydrologic cycles. Western juniper effectively intercepts rain and snow (Young and Evans 1984, Larsen 1993). As conifer canopy increases in an aspen community, it intercepts snow subjecting it to sublimation. This results in less water in the snowpack under the mixed aspen-conifer stand than under pure aspen (Johnston 1971). Conifers also use more water per year than aspen (Gifford et al. 1983, 1984, Jaynes 1978). Further study is required to determine the effects and changes in hydrologic cycles in aspen sites overtaken by western juniper.

\section{Management Implications}

Aspen stands in the northwest Great Basin are in a state of decline. Threefourths of the aspen communities below 2,133 m elevation have either been replaced, are being replaced, or have establishing populations of western juniper. The magnitude of western juniper encroachment demands immediate action. Without active management, stands of aspen in this region will continue to decline and may be permanently lost. The loss of aspen communities would decrease landscape diversity and remove a community type that is important to many wildlife species. Since establishment of aspen from seed is rare under current climatic conditions in the Intermountain Region (McDonough 1985), stands that are totally replaced by western juniper have likely passed a threshold from immediate planning and proactive management will allow for the restoration and maintenance of this resource.

The reintroduction of fire and the decrease of herbivore pressure are key factors in the restoration of aspen. To sustain or restore aspen, prescribed fire or allowed a deciduous to conifer woodland. Only natural fire are the best tools for eliminating young juniper and inducing aspen regeneration. In advanced cases, fine fuel levels may be too low to carry adequate fires. In addition, high fuel moisture in aspen communities commonly limits fire. These circumstances necessitate cutting western juniper within the stand one year prior to burning in order to use their dried foliage to carry a fire. Precautions should also be taken to protect young aspen suckers from excessive herbivory. The continued growth in elk populations in the northwest Great Basin will likely increase the browsing pressure on young aspen trees. Further studies on the degree and extent of herbivory in aspen stands as well as on effective means of control would help direct management in efforts to maintain aspen communities in the desert landscape. Key questions that need further study for stands being replaced by western juniper are: 1) at what point is an aspen stand beyond the threshold of restoration, and 2) how long will the parent root system stay intact and viable once no aspen trees are present?

\section{Literature Cited}

Anderson E.W., M.M. Borman, and W.C. Krueger. 1998. The Ecological Provinces of Oregon - a treatise on the basic ecological geography of the state. Oregon Agr. Exp. Sta., Corvallis, Ore.

Bailey, R.B. 1994. Description of the Ecoregions of the United States. USDA-FS Misc.Pub. 1391.

Baker, F.S. 1925. Aspen in the central Rocky Mountain region. USDA Bull. 1291.

Bartos, D.L. and R.B. Campbell. 1998a. Decline of quaking aspen in the Interior West -examples from Utah. Rangelands 20:17-25.

Bartos, D.L. and R.B. Campbell. 1998b. Water depletion and other ecosystem values forfeited when conifer forests displace aspen communities. In: D.F. Potts (Ed), 1998. proceedings of AWRA Specialty Conference, Rangeland Manage. and Water Resour., Amer. Water Resourc. Assoc., Herndon, Virg., TPS-98-1, 474pp.

Bartos, D.L. and N.V. DeByle. 1981. Quantity, decomposition, and nutrient dynamics of aspen litterfall in Utah. For. Sci. 27:381-390.

Bartos, D.L. and W.F. Mueggler. 1981. Early succession in aspen communities following fire in western Wyoming. J. Range Manage. 34:315-318.

Bartos, D.L., J.K. Brown, and G.D. Booth. 1994. Twelve years biomass response in aspen communities following fire. J. Range Manage. 47:79-83.

Bartos, D.L., W.F. Mueggler, and R.B. Campbell. 1991. Regeneration of aspen suckering on burned sites in Western 
Wyoming. USDA For. Ser. Gen. Tech. Rep. INT-448.

Bates, J.D., T.J. Svejcar, and R.F. Miller. 2002. Effects of juniper cutting on nitrogen mineralization. J. Arid. Environ. (in press).

Brown, J.K. and N.V. DeByle. 1987. Fire damage, mortality, and suckering in aspen. Can. J. For. Res. 17:1100-1109.

Cronquist, A., N.H. Holmgren, J.L. Reveal, and P.K. Holmgren. 1972. Intermountain flora. New York Bot. Garden, Bronx, N.Y.

DeByle, N.V. 1985. Animal impacts. p.115-123. In: N.V. Debyle and R.P. Winokur (eds.) Aspen: ecology and management in the Western United States. USDA For. Ser. Gen. Tech. Rep. RM-119.

DeByle, N.V., P.J. Urness, and D.L. Blank. 1989. Forage quality in burned and unburned aspen communities. USDA For. Ser. Gen Tech. Rep. INT-404.

Gifford, G.F., W. Humphries, and R.A. Jaynes. 1983. A preliminary quantification of the impacts of aspen to conifer succession on water yield within the Colorado River Basin (A process aggravating the salt pollution problem). Utah State Univ., Water Res. Lab., Hydralics. and Hydrol. Series UWL/II83/01, Logan, Utah.

Gifford, G.F., W. Humphries, and R.A. Jaynes. 1984. A preliminary quantification of the impacts of aspen to conifer succession on water yield. II. Modeling results. Water Res. Bull. 20:181-186.

Houston, W.R. 1954. A condition guide for aspen ranges of Utah, Nevada, southern Idaho, and western Wyoming. USDA For. Ser. Pap. INT-32.

Jaynes, R.A. 1978. A hydrologic model of aspen-conifer succession in the western United States. USDA For. Ser. Res. Pap. INT-213.
Johnston, R.S. 1971. Rainfall interception in a dense Utah aspen clone. USDA For. Ser. Res. Note INT-143.

Jones, J.R., and N.V. DeByle. 1985. Morphology. p. 11-18 In: Debyle, N.V. and R.P. Winokur (eds.) Aspen: ecology and management in the Western United States. USDA For. Ser. Gen. Tech. Rep. RM-119.

Kay, C.E. 1997. Is aspen doomed? J. For. 95: 4-11.

Kay, C.E. and D.L. Bartos. 2000. Ungulate herbivory on Utah aspen: assessment of longterm exclosures. J. Range Manage. 53:145-153.

Larsen, R.E. 1993. Interception and water holding capacity of western juniper. Ph.D Diss. Oregon State Univ. Corvallis, Ore.

Maser, C., J.W. Thomas, and R.G. Anderson. 1984. Wildlife habitats in managed rangelands - the Great Basin of southeastern Oregon - the relationship of terrestrial vertebrates to plant communities. Part 1, Text. USDA For. Ser. Gen. Tech. Rep. PNW-172.

McDonough, W.T. 1985. Sexual reproduction, seeds, and seedlings. p. 25-28 In: N.V. Debyle and R.P. Winokur (eds.) Aspen: ecology and management in the Western United States. USDA For. Ser. Gen. Tech. Rep. RM119.

Miller, R.F. and J. Rose. 1995. Historic expansion of Juniperus occidentalis (western juniper) in southeastern Oregon. Great Basin Natur. 55:37-45.

Miller, R.F. and J. Rose. 1999. Fire history and western juniper encroachment in sagebrush steppe. J. Range Manage. 52:550-559.

Miller, R.F. and P.E. Wigand. 1994. Holocene changes in semiarid pinyonjuniperwoodlands. BioSci. 44:465-474.
Miller, R.F., T.J. Svejcar, and J.F. Rose. 2000. Impacts of western juniper on plant community composition and structure. J. Range Manage. 53:574-585.

Miller, R.F., T.J. Svejcar, and N.E. West. 1994. Implications of livestock grazing in the Intermountain sagebrush region: plant composition. p. 101-146. In: M. Vavra, W.A. Laycock, and R.D. Pieper, (eds.), Ecological Implications of Livestock Herbivory in the West. Soc. Range Manage., Denver, Colo.

Mitton, J.B. and M.C. Grant. 1996. Genetic variation and the natural history of quaking aspen. BioSci. 46: 25-31.

Mueggler, W.F. 1985. Vegetation associations. p. 45-56 In: N.V. Debyle and R.P. Winokur (eds.) Aspen: ecology and management in the Western United States. USDA For. Ser. Gen. Tech. Rep. RM-119.

Mueggler, W.F. 1989. Age distribution and reproduction of Intermountain aspen stands. West. J. Appl. For. 4:41-45.

Romme, W.H., M.G. Turner, L.L. Wallace, and J.S. Walker. 1995. Aspen, elk, and fire in northern Yellowstone National Park. Ecol. 76:2097-2106.

SAS Institute. 1990. User's guide, version 6.03 edition. SAS Institute, Cary, N.C.

Tausch, R.J., N.E. West, and A.A. Nabi. 1981. Tree age and dominance patterns in Great Basin pinyon-juniper woodlands. J. Range Manage. 34:259-264.

Young, J.A., and R.A. Evans. 1984. Stem flow on western juniper (Juniperus occidentalis) trees. Weed Sci. 32:320-327. 


\title{
Climatic influences on recruitment of 3 subspecies of Artemisia tridentata
}

\author{
AARON M. MAIER, BARRY L. PERRYMAN, RICHARD A. OLSON, AND ANN L. HILD
}

Authors are Ph.D. Candidate, Department of Rangeland Ecosystem Science, Colorado State University, Fort Collins, Colo. 80524; assistant professor, School of Veterinary Medicine, University of Nevada, Reno, Nev 89557; associate professor and assistant professor, Department of Renewable Resources, University of Wyoming, Laramie, Wyo. 82071.

\begin{abstract}
Previous research suggested that big sagebrush (Artemisia tridentata Nutt.) recruitment occurs in pulses consistent with favorable climatic conditions. In 1997, 75 stem sections were collected from 9 stands of each of the 3 subspecies of big sagebrush in Wyoming along elevation and climatic gradients. Annual growth rings were used to identify the year plants were established. Large cohorts of Wyoming big sagebrush (A. tridentata ssp. wyomingensis Beetle and Young) appeared in 1982, 1981, 1964, 1961, and 1955. Basin big sagebrush (A. tridentata ssp. tridentata Beetle and Johnson) cohorts flourished in 1991, 1986, 1985, 1982, and 1977. Mountain big sagebrush (A. tridentata ssp. vaseyana [Rydb.] Beetle) cohorts prospered in 1985, 1982, 1981, 1979, and 1974. Mean monthly precipitation and temperature records were compared to years with high and low recruitment using logistic regression models at 3 geographic scales (single-stand, regional, statewide). Wyoming big sagebrush recruitment was greatest in years with above-average December and January precipitation occurring after the first growing season $\left(r^{2}=0.10,0.04, P<0.05\right)$. Basin big sagebrush recruitment was most successful in years with above-average March, May, and June precipitation during the first growing season $\left(r^{2}=0.06,0.09,0.18, P<0.05\right)$. Mountain big sagebrush recruitment was greatest in years with below-average February, April, and May precipitation after the first growing season $\left(r^{2}=0.03,0.04,0.04, P<0.05\right)$. While variable precipitation patterns appear to contribute significantly to recruitment of big sagebrush, responses among the 3 major subspecies were quite variable. More complex models need to be developed to foster our understanding of the mechanisms affecting big sagebrush establishment.
\end{abstract}

Key Words: climate, big sagebrush, seedling establishment

The 3 big sagebrush (Artemisia tridentata Nutt.) subspecies have a wide ecological amplitude (Beetle and Johnson 1982) in the western United States. They help prevent erosion, provide wildlife habitat and forage, and improve rangeland aesthetics (Vale 1974). Because of big sagebrush's ecological significance in Wyoming's rangelands, the Wyoming Department of

Research was funded by the Wyoming Abandoned Coal Mined-Lands Research Program, University of Wyoming. This support was administered by the Wyoming Departmental of Environmental Quality from funds returned to the state of Wyoming from the Office of Surface Mining, U.S. Department of the Interior.

Manuscript accepted 29 Apr. 2000.

\section{Resumen}

La investigación previa sugiere que el establecimiento de "Big sagebrush" (Artemisia tridentata Nutt.) ocurre en eventos concordantes con condiciones climáticas favorables. En 1997 se colectaron 75 secciones de tallos de 9 poblaciones de cada una de las 3 subespecies de "Big sagebrush", la colecta se realizo en Wyoming a lo largo de gradientes climáticos y de elevación. Los anillos anuales de crecimiento se utilizaron para identificar el año en el que se establecieron las plantas. Generaciones grandes de "Wyoming big sagebrush" (A. tridentata ssp. wyomingensis Beetle and Young) aparecieron en 1982, 1981, 1964, 1961 y 1955. Generaciones de "Basin big sagebrush" (A. tridentata ssp. tridentata Beetle and Johnson) florecieron en 1991, 1986, 1985, 1982 y 1977. Generaciones de "Mountain big sagebrush" (A. tridentata ssp. vaseyana [Rydb.] Beetle) prosperaron en 1985, 1982, 1981, 1979 y 1974. Los registros de medias mensuales de temperatura y precipitación se compararon entre años de establecimiento alto y bajo, para ello se utilizaron modelos de regresión logística en 3 escalas geográficas (nivel de población, regional y estatal). El establecimiento de "Wyoming big sagebrush" fue mayor en años en los que la precipitación de los meses de Diciembre y Enero después de la primer estación de crecimiento fue arriba del promedio $\left(r^{2}=0.10,0.04, P<0.05\right)$. El establecimiento de "Basin big sagebrush" fue más exitoso en los años en los que la precipitación de los meses de Marzo, Mayo y Junio de la primera estación de crecimiento fue arriba del promedio $\left(r^{2}=0.06,0.09\right.$, $0.18, P<0.05)$. El establecimiento de "Mountain big sagebrush" fue mayor en años en los que la precipitación promedio de los meses de Febrero, Abril y Mayo después de la primer estación de crecimiento fue abajo del promedio $\left(\mathbf{r}^{2}=0.03,0.04,0.04, P<0.05\right)$. Mientras que patrones variables de precipitación parecen contribuir significativamente con el establecimiento de "Big sagebrush", las respuestas entre las 3 subespecies principales fue muy variable. Se necesita desarrollar modelos más complejos para avanzar en nuestro entendimiento de los mecanismos que afectan el establecimiento de "Big sagebrush".

Environmental Quality (DEQ) has legally mandated its reestablishment on disturbed mined-lands where it previously occurred. Success at reestablishing Wyoming big sagebrush (A. tridentata ssp. wyomingensis Beetle and Young) has been sporadic in northeast Wyoming, the edge of its distribution range (Lyford 1995).

Big sagebrush distribution is closely tied to temperature and precipitation (Cawker 1980). Successful recruitment of big sagebrush is partially dependent on available moisture (Sturges 1976, Cawker 1980, Lyford 1995) and seed viability (McDonough and 
Harniss 1974). Big sagebrush seedling survival is reduced when high temperatures lower available soil moisture and increase evapotranspiration rates (Young et al. 1991). Throughout most of the growing season, temperature is not as critical as moisture for big sagebrush seedling germination and survival (Harniss and McDonough 1976). Past climate appears to influence the age structure of big sagebrush stands and in drought years seedling establishment is reduced (Cawker 1980). Examination of historical climate patterns may identify specific precipitation and temperature conditions favorable for big sagebrush recruitment and survival.

Our objective was to determine if specific combinations of monthly precipitation and mean monthly temperature were correlated with high big sagebrush recruitment. To do this, long-term monthly precipitation and mean monthly temperature variables were logistically regressed against high- and no-recruitment years on native, undisturbed sagebrush stands in Wyoming.

\section{Materials and Methods}

\section{Field Sampling and Laboratory Preparation}

In 1997, we visited 27 big sagebrush sites ( 9 sites for each of the 3 subspecies) along elevation and climatic gradients in Wyoming. The 3 major subspecies we sampled were Wyoming big sagebrush, basin big sagebrush (A. tridentata ssp. tridentata Beetle and Johnson), and mountain big sagebrush (A. tridentata ssp. vaseyana [Rydb.] Beetle). At each site, 75 stem sections were collected from sagebrush. Elevations ranged from $960 \mathrm{~m}$ in the Powder River Basin of northeast Wyoming to $2,700 \mathrm{~m}$ in the Bighorn Mountains in north central Wyoming. Average annual precipitation, measured near the stands, ranged from $20 \mathrm{~cm}$ in the Bighorn Basin to $64 \mathrm{~cm}$ north of Pinedale in western Wyoming (WRDS 1997). Stands were selected with a variety of age classes of big sagebrush, similar cover and topography, and absence of excessive grazing or other disturbances. Sites were also selected to minimize supplemental moisture or subsurface runoff due to microsite influences, which reduces variations in demography between sites (Bonham et al. 1991). All stands occupied at least 1 ha.

Stem sections for Wyoming big sagebrush were collected from 3 stands in northeast Wyoming near Rochelle; 3 stands in the South Fork of the Powder River watershed, northwest of Casper in central Wyoming; and 3 stands in southwest Wyoming near Pinedale. Stem sections for basin big sagebrush were collected from 3 stands near Pinedale; 3 stands near Worland, on the west slope of the Bighorn Mountains; and 3 stands near Farson, in southwest Wyoming. Stem sections for mountain big sagebrush were collected from 3 stands near Pinedale; 3 stands near Buffalo; on the east slope of the Bighorn Mountains; and 3 stands west of Laramie, near Elk Mountain in south central Wyoming. Each of 3 stands in a regional grouping were located within a $10 \mathrm{~km}$ radius. Stand locations were determined with a Global Positioning System, and coordinates and elevations are found in Perryman and Olson (2000).

A stratified random sampling procedure (Cochran 1977) was used to select the shrubs sampled in each stand. A 100 meter baseline transect was located within each stand, 8 random points were selected along the transect, and 100 meter perpendicular transects established from each point along the baseline. Along each perpendicular transect, 10 random points were marked, and we selected the closest big sagebrush plant. Cross-sections were obtained by sawing individual plants $4-6 \mathrm{~cm}$ below ground level (Ferguson 1964) to ensure that the pith and first annual growth ring were counted. Ferguson (1964) and Cawker (1980) demonstrated that annual growth rings in big sagebrush may be used to accurately determine the age of individual plants. If a cross section had no pith it was discarded and replaced. Cross sections were smoothed using 80-200 grit sandpaper and coated with tung oil to improve contrast between annual growth rings.

Year of establishment was determined for each cross-section by enumerating annual growth rings from the pith to the exterior surface. One or more big sagebrush plants established in the same year comprised a cohort.

Inter-annual or false rings appear in conifers when secondary xylem growth surges 2 or more times in a growing season. These rings have not been encountered in big sagebrush at northern latitudes and higher elevations (Diettert 1938, Moss 1940, Ferguson 1964). Distinct growth layers in big sagebrush stems reduces the chance of misidentifying annual rings. Around some portions of a stem growth rings might not form. Complete absence of rings are rarely encountered, however, due to the unique nature of annual growth ring formation in big sagebrush (Ferguson 1964).
Many older stems were "lobed" or "rosette" in form and lacked radial symmetry. Often decumbent and decadent older stems experienced open pith exposure and loss to decomposition. Accurate age assessment was not possible without an intact pith, so our sampling favored single-stemmed plants with intact piths over individuals that lacked radial symmetry. Therefore, some older plants may have been excluded from our study.

\section{Climate Data}

All stands were located within $10 \mathrm{~km}$ of 10 separate National Weather Service climate stations. Weather data from each station was provided by WRDS (1997). Weather conditions at stands were assumed similar to nearby climate stations. Mean monthly temperatures were calculated from mean daily temperatures for each month. Data from Tensleep $4 \mathrm{NE}$ and Kaycee climate stations were averaged to approximate weather conditions at 3 stands of mountain big sagebrush at higher elevations in the Bighorn Mountains. Missing monthly precipitation and mean monthly temperature values accounted for less than 1 percent of the scheduled data for each station. Missing monthly precipitation and mean monthly temperature data were substituted with corresponding monthly values from adjacent climate stations using the normal ratio method (Brooks et al. 1991).

\section{Statistical Analyses}

Logistic regression was used to relate cohort establishment years for each subspecies to climatic variables at 3 geographic scales (stand, regional stand combination, and statewide). Within each stand, the 5 largest cohorts within each period of record and their corresponding year of establishment were assigned a value of 1 . Five years with no evidence of recruitment were randomly selected and assigned a value 0 . The bimodal frequency of establishment was represented by the dependent, dichotomous variable $\mathrm{Y}=1,0$. Independent $(\mathrm{X})$ monthly precipitation and mean monthly temperature variables were considered for 3-year periods surrounding the establishment year (pre-establishment, establishment, and post-establishment years). Cohorts established prior to 1949 were excluded from the analysis due to the absence of climate data.

For each stand, 36 monthly precipitation and 36 mean monthly temperature variables were regressed against each of the 5 recruitment years and 5 non-recruitment years. This procedure yielded a total of 
720 predictor variables in each singlestand regression model, 1080 predictor variables in each regional regression model, and 3240 predictor variables in each statewide regression model.

Logistic regression analysis, a regression for categorical data, is often used for relating climate data to population demographics (Hosmer and Lemeshow 1989, Christensen 1997). Logistic regression analyses using maximum likelihood estimation were employed to examine the relationship between climate $(\mathrm{X})$ and cohort establishment years $(Y=1,0)$. Logistic regression overcomes standard linear regression assumptions (e.g. heteroscedasticity, non-normal error terms, nonlinearity, and predicted probabilities beyond 1.0) by providing a logit dependent variable. The equation expressing the relationship between the climate $(\mathrm{X})$ and cohort $(\mathrm{Y}=1,0)$ variables is: $\operatorname{logit}(\mathrm{Y})=\alpha$ $+\beta_{1} X_{1}+\beta_{2} X_{2}+\ldots+\beta_{k} X_{k}$.

Relationships were judged significant when $\mathrm{P}<0.05$. A significant logistic regression was not used to predict specific monthly precipitation and mean monthly temperature amounts surrounding cohort establishment, but, rather climatic differences between highly successful recruitment years and years with no recruitment.

\section{Results and Discussion}

Figure 1 depicts a logistic probability plot at the regional scale. Ordered by year at the statewide scale, the 5 largest cohorts of Wyoming big sagebrush appeared in 1982, 1981, 1964, 1961, and 1955; basin

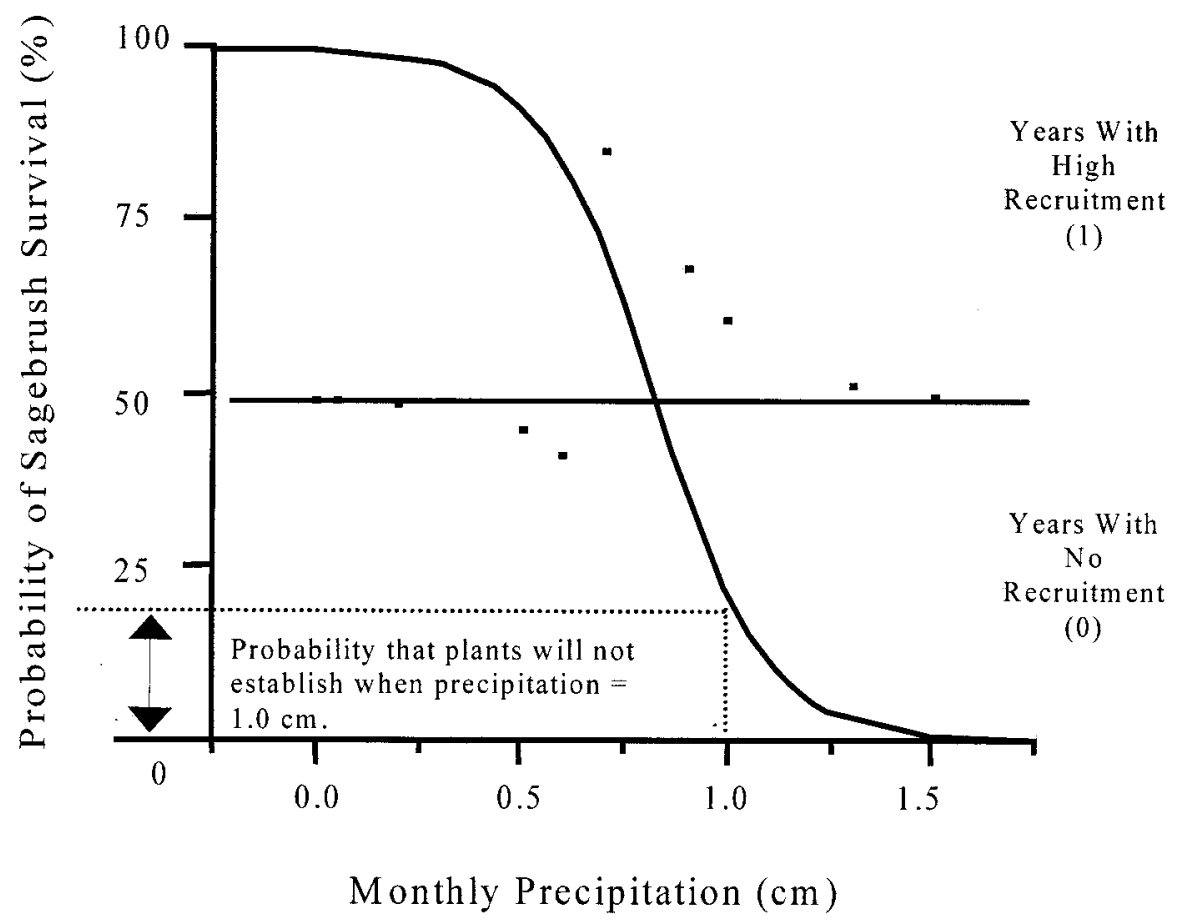

Fig. 1. Depiction of a logistic probability plot for December precipitation following initial growing season of northeast Wyoming big sagebrush. Dots represent year of establishment.

big sagebrush in 1991, 1986, 1985, 1982, and 1977; and mountain big sagebrush in 1985, 1982, 1981, 1979, and 1974.

\section{A. tridentata ssp. wyomingensis}

For Wyoming big sagebrush, 2 variables, above-average December and January precipitation immediately following seedling establishment, were positively correlated $\left(\mathrm{r}^{2}=0.10,0.04\right.$ respectively,
$\mathrm{P}<0.05$, Table 1) to seedling establishment at the statewide scale and at the northeast regional scale $\left(\mathrm{r}^{2}=0.54,0.13\right.$ respectively, $\mathrm{P}<0.05$, Table 1). The relationship between December precipitation and cohort establishment was highest in northeast Wyoming $\left(r^{2}=0.54\right)$. Coefficients of determination were relatively low because variance was spread across 360 monthly precipitation variables. We are confident that

Table 1. Significant coefficients of determination ( $\mathbf{r} 2$ ) for logistic regression models relating establishment patterns of 3 subspecies of bigsagebrush to monthly precipitation at regional and statewide scales in Wyoming.

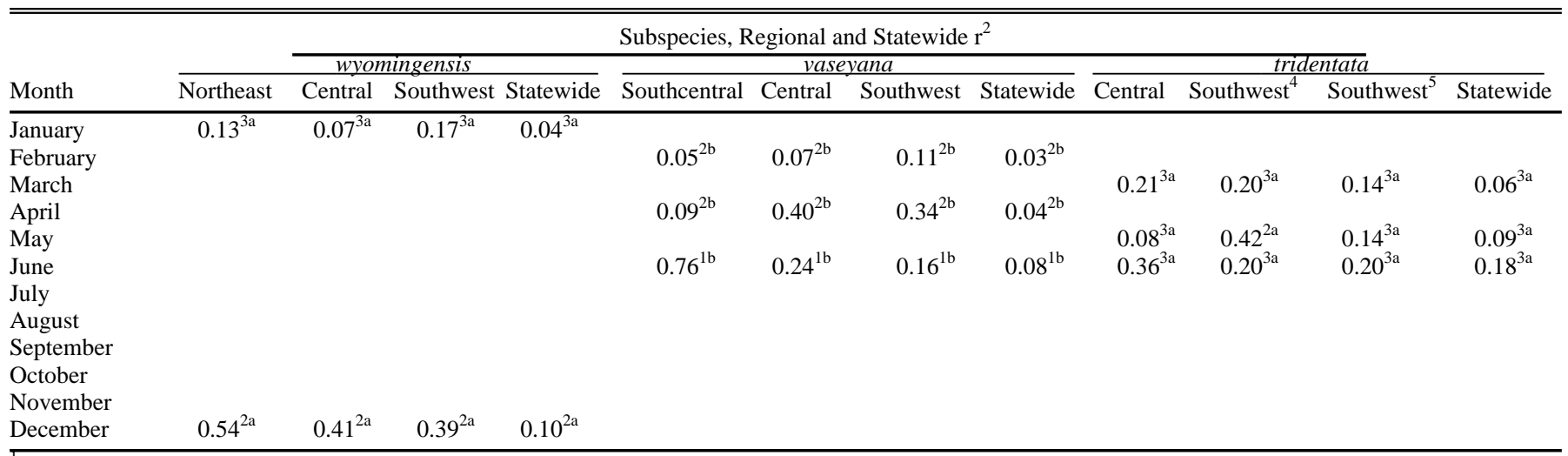

${ }^{\mathrm{T}}$ Year before Establishment

${ }_{3}^{2}$ Year of Establishment

${ }^{3}$ Year After Establishment

${ }^{4}$ West Slope of the Green River Basin

${ }^{5}$ East Slope of the Green River Basin

${ }^{\mathrm{a}}$ Indicates above-average category

${ }^{\mathrm{b}}$ Indicates below-average category 
these $r^{2}$ values indicate relationships between monthly climate and cohort establishment. Temperature variables were not significant predictors of cohort establishment $(P>0.05)$. Results indicate that Wyoming big sagebrush recruitment was high in years where the winter after the first growing season received above-average December and January precipitation, but especially high December precipitation.

In Wyoming, winter precipitation typically occurs as snow. Winters with persistent snow cover may protect juvenile Wyoming big sagebrush plants from cold temperatures and high winds, effectively enhancing survival. Conversely, little or no snow accelerates winter desiccation, possibly reducing seedling survival in years with little or no snowpack. Aboveaverage snowfall is likely to furnish more soil moisture for subsequent seedling growth. Jones (1991) hypothesized that winter precipitation and augmented deep soil moisture does not increase big sagebrush seedling survival during the year of establishment.

\section{A. tridentata ssp. tridentata}

Years of high basin big sagebrush recruitment were associated with aboveaverage June precipitation during the year of establishment $\left(\mathrm{r}^{2}=0.42, \mathrm{P}<0.05\right)$ in southwest Wyoming, and above-average March, May, and June precipitation the following year $\left(\mathrm{r}^{2}=0.06,0.09,0.18, \mathrm{P}<\right.$ $0.05)$ at the statewide scale. There were also significant relationships between temperature variables and cohort establishment. Warm December temperatures the year after establishment were positively related $\left(\mathrm{r}^{2}=0.06,0.10, \mathrm{P}<0.05\right)$ to basin big sagebrush cohort establishment. This relationship was consistent at all 3 geographic scales. It is likely that warm temperatures during December improves seedling survival. The relationship between above-average growing season moisture in years following high recruitment was greatest in southwest Wyoming $\left(r^{2}=0.14-0.42\right.$, Table 1$)$.

The precipitation variables associated with basin big sagebrush recruitment correlated significantly with periods of high moisture demand by seedlings (Eissenstat and Caldwell 1988, Bonham et al. 1991, Bai et al 1997). Basin big sagebrush seedling germination and survival in Wyoming is generally high due to high seed yields and available soil moisture (Harniss and McDonough 1976). Years with unusually high growing season moisture thus provide optimum conditions for high levels of recruitment.

\section{A. tridentata ssp. vaseyana}

Years of high mountain big sagebrush recruitment were characterized by belowaverage February, April, and June precipitation the year of establishment $\left(r^{2}=0.03\right.$, $0.04,0.04)$ across all 3 geographic scales $(\mathrm{P}<0.05$, Table 1). These coincided with the establishment of large cohorts in years of below-average spring precipitation. Young et al. (1991) and McDonough and Harniss (1974) indicated that mountain big sagebrush seedling germination is reduced with cooler temperatures. Spring moisture is coincident with cooler temperatures at high elevations, creating conditions that appear to reduce sagebrush recruitment. Since mountain big sagebrush seedling germination is generally adequate every year at high elevations (McDonough and Harniss 1974), years with unusually low spring and early summer precipitation may correspond with higher temperatures that enhance seedling survival. Our analysis indicated that temperature variables were poor predictors of recruitment, so there may be an inverse relationship between low precipitation and higher temperatures. Data from Burke et al. (1989) indicate that snow cover and its effect on soil moisture and temperature affect the distribution of mountain big sagebrush. This may be the case, but there may be climatic mechanisms operating at finer scales than evaluated by our model.

\section{Conclusions}

High levels of Wyoming big sagebrush recruitment were positively correlated with above-average winter precipitation following the first growing season; basin big sagebrush recruitment was positively correlated with growing season moisture the year of establishment; and mountain big sagebrush recruitment was positively correlated with low spring precipitation during the first growing season. These relationships were consistent across all 3 geographic levels, but strongest at the regional scale (Table 1 ). These findings support earlier evidence of climatic control of big sagebrush seedling survival (Sturges 1976, West 1978, Cawker 1980).

Since recruitment of big sagebrush cohorts occurs in years with favorable precipitation (Went 1955, May 1975, West et al. 1979, Cawker 1980), artificially creating similar conditions on disturbed minedlands might enhance recruitment. A few studies have examined the relationship of mulching and snow fences to enhance seedling establishment on reclaimed mined-lands in northeast Wyoming (Schuman et al. 1998), but no one has investigated the impacts of snow cover on seedling survival. We speculate that additional winter snow cover may be the key to reestablishment of Wyoming big sagebrush in areas of northeast Wyoming where it occurs on the edge of its distribution range.

In western Wyoming, where winter snow cover occurs more frequently (WRDS 1997), reestablishment of Wyoming big sagebrush is more successful (Lyford 1995). Winter snow cover may reduce wind exposure and desiccation, thereby enhancing seedling survival (Burke et al. 1989, Young et al. 1990). In northeast Wyoming, winter snow cover is sporadic to nonexistent. Wyoming big sagebrush is difficult to reestablish on northeast Wyoming mined-lands (Coenenberg 1982, Cockrell et al. 1995, Stahl et al. 1998). These regional differences in reestablishment success appear to be due to differences in the amount of winter precipitation. Our results indicate that only years with above-average winter precipitation after the first growing season are conducive to high levels of Wyoming big sagebrush recruitment.

Climatic conditions supporting widespread pulses of big sagebrush establishment on native sites should be examined in greater depth. Since factors affecting plant establishment are extremely complex, we cannot conclude that winter precipitation is the primary determinant of cohort establishment. We did not examine the effects of snow cover on Wyoming big sagebrush recruitment. Since similar combinations of monthly precipitation and mean monthly temperature exist at all geographic scales for each subspecies, our data provide strong evidence that precipitation variables significantly affect high levels of seedling recruitment on native, undisturbed big sagebrush sites throughout Wyoming.

\section{Literature Cited}

Bai, Y., T. Booth, and E.R. Roos. 1997. Effect of seed moisture on Wyoming big sagebrush seed quality. J. Range Manage. 50:419-422.

Beetle, A. A. and K. L. Johnson. 1982. Sagebrush in Wyoming. University of Wyo. Agr. Exp. Sta., Laramie, Wyo.

Bonham, C.D., T.R. Cottrell, and J.F. Mitchell. 1991. Inferences for life history strategies of Artemisia tridentata subspecies. J. of Veg. Sci. 2:339-344.

Brooks, K.N., P.F. Ffolliott, H.M. Gregersen, and J.L. Thames. 1991. Hydrology and the Management of Watersheds. Iowa State University Press, Ames, I.a. 
Burke, I.C., W.A. Reiners, and R.K. Olson. 1989. Topographic control of vegetation in a mountain big sagebrush steppe. Vegetatio. 84:77-86.

Cawker, K.B. 1980. Evidence of climatic control from population age structure of Artemisia tridentata Nutt. in southern British Columbia. J. Biogeogr. 7:237-248.

Christensen, R. 1997. Log-Linear Models and Logistic Regression. Springer, New York, N.Y.

Cochran, W.G. 1977. Sampling Techniques. John Wiley \& Sons, Inc., New York, N.Y.

Cockrell, J.R., G.E. Schuman, and D.T. Booth. 1995. Evaluation of cultural methods for establishing Wyoming big sagebrush on mined lands p. 784-795. In: G.E Schuman and G.F. Vance (ed.) Decades later: A time for reassessment. Amer. Soc. Surf. Mining Reclam., Princeton, W.V.

Coenenberg, J.G. 1982. Methods for establishment of diverse native plant communities at the Rosebud Mine. p.B6(1-20). In: Proc. Symp. Mining Reclam. of Coal Mined Lands in the Northern Great Plains. Mont. Agr. Exp. Sta. Bozeman, Mont.

Diettert, R.A. 1938. The morphology of Artemisia tridentata Nutt. Lloydata, 1:3-74.

Eissenstat, D.M. and M.M. Caldwell. 1988. Competitive ability is linked to rates of water extraction. Oecologia 75:1-7.

Ferguson, C. W. 1964. Annual rings in big sagebrush. Papers of the Laboratory of TreeRing Research No. 1. The Univ. of Arizona Press, Tucson, Ariz.
Harniss, R.O. and W.T. McDonough. 1976. Yearly variation in germination in three subspecies of big sagebrush. J. Range Manage. 29:167-168.

Hosmer, D.W. and S. Lemeshow. 1989. Applied Logistic Regression. Wiley \& Sons, New York, N.Y.

Jones, G.P. 1991. Seedling survival and adult plant water relations of black sagebrush and big sagebrush in the Laramie Basin. Ph.D. Thesis, Univ. of Wyoming. Laramie, Wyo.

Lyford, M.E. 1995. Shrub establishment on drastically disturbed lands. M.S. Thesis, Univ. Wyoming. Laramie, Wyo.

May, M. 1975. Moisture relationships and treatments in revegetating strip mines in the arid west. J. Range Manage. 28:334-335.

McDonough, W.T. and R.O. Harniss. 1974. Effects of temperature on germination in three subspecies of big sagebrush. J. Range Manage. 27:204-205.

Moss, E.H. 1940. Interxylary cork in Artemisia with reference to its taxonomic significance. Amer. J. Bot., 27:762-768.

Perryman, B.L. and R.A. Olson. 2000. Agestem diameter relationships of big sagebrush and their management implications. J. Range. Manage. 53:342-346.

Schuman, G.E., D.T. Booth, and J.R. Cockrell. 1998. Cultural methods for establishing Wyoming big sagebrush on mined lands. J. Range Manage. 51:223-230.

Stahl, P. D., G.E. Schuman, S.M. Frost. and S.E. Williams. 1998. Arbuscular mycorrhizae and water stress tolerance of Wyoming big sagebrush seedlings. J. Soil Sci. 62:1309-1313.
Sturges, D.L. 1976. Hydrologic relations on undisturbed and converted big sagebrush lands: The status of our knowledge. Forest Service Res. Pap. RM-140. Fort Collins, Colo.

Vale, T.R. 1974. Sagebrush conversion projects: An element of contemporary environmental change in the western United States. Biol. Cons. 6:274-284.

Went, R.W. 1955. The ecology of desert plants. Sci. Amer. 192:68-75.

West, N.E. 1978. Basic synecological relationships of sagebrush dominated lands in the Great Basin and Colorado plateau. In: The sagebrush ecosystem, A symposium, Logan, Ut., College of Natural Resources, Utah State Univ., Logan, Ut.

West, N.E., K.H. Rea, and R.O. Harniss. 1979. Plant demographic studies in sagebrush-grass communities of southeastern Idaho. Ecol. 60:376-388.

WRDS (Wyoming Water Resources Data System). 1997. National Weather Service Climate Station Data. Wyoming Water Resources Center, University of Wyoming, Laramie, Wyo.

Young, J.A., R.A. Evans, and D.E. Palmquist. 1990. Soil surface characteristics and emergence of big sagebrush seedlings. J. Range Manage. 43:358-367.

Young, J.A., D.E. Palmquist, and R.A. Evans. 1991. Temperature profiles for germination of big sagebrush seeds from native stands. J.Range Manage. 44:385-390. 


\title{
Grazing impacts on soil nitrogen and phosphorus under Parkland pastures
}

\author{
V.S. BARON*, A.C. DICK, E. MAPFUMO, S.S. MALHI, M.A. NAETH, AND D.S. CHANASYK
}

Research scientist and research associate with Lacombe Research Centre, Agriculture and Agri-Food Canada, 6000 C\&E Trail, Lacombe, Alberta, Canada T4L 1W1; Post-doctoral fellow with the Department of Renewable Resources, University of Alberta, Edmonton, Alberta, Canada T6G 2H1; research scientist with the Melfort Experimental Farm, Agriculture and Agri-Food Canada, Box 1240, Melfort, SK, SOE 1A0; and professors with the Department of Renewable Resources, University of Alberta, Edmonton, Alberta, Canada T6G 2H1. * Corresponding author (Email address: BARONV@EM.AGR.CA).

\section{Abstract}

Because intensive grazing is new to the humid western Canadian parkland (prairies), there is little information available about its effects on soil $N$ and $P$ status. This study addressed the question of grazing intensity and pasture species effects on soil macronutrient status in a Typic Haplustoll at Lacombe, Alberta. Paddocks of smooth bromegrass (Bromus inermis Leyss.), meadow bromegrass (Bromus riparius Rhem.), and winter triticale ( $X$ Triticosecale Wittmack.), replicated 4 times, were subjected to 3 grazing intensities (heavy, medium, and light as defined by frequency and severity of defoliation) using yearling beef heifers. Nitrogen $(\mathbf{N}), \mathbf{P}$ and $\mathrm{K}$ fertilisers were broadcast annually at $\mathbf{1 0 0}$, 22 and $42 \mathrm{~kg} \mathrm{ha}^{-1}$ during production years. The experiment was maintained on the same paddocks for 4 years. In the establishment year and in the third and fourth production years, soil samples were taken randomly from each paddock to a depth of 60 cm. Concentrations of nitrate-N $\left(\mathrm{NO}_{3}-\mathrm{N}\right)$, ammonium-N $\left(\mathrm{NH}_{4}^{-}\right.$ $\mathrm{N}$ ), mineral-N (the sum of $\mathrm{NO}_{3}-\mathrm{N}$ and $\mathrm{NH}_{4}-\mathrm{N}$ ), total Kjeldahl-N, and extractable-P were determined in the $0-15,15-30,30-60$, and 0-60-cm depths. Nitrate-N concentration was (1.7 to 2.4 times) greater for heavy than light grazed treatments for each soil depth increment and the amount of $\mathrm{NO}_{3}-\mathrm{N}$ in the $0-60 \mathrm{~cm}$ depth was 2.2 times greater than light paddocks. More $\mathrm{NO}_{3}-\mathrm{N}$ was measured under perennials than triticale $\left(22.2 \mathrm{vs} 13.6 \mathrm{mg} \mathrm{kg}^{-1}\right.$, respectively) at the 30-60-cm depth. Ammonium-N amount (0-60 cm) was greater in meadow bromegrass $\left(30 \mathrm{~kg} \mathrm{ha}^{-1}\right)$ than in triticale $\left(25 \mathrm{~kg} \mathrm{ha}^{-1}\right)$, but not smooth bromegrass paddocks for the 0 15-cm depth. Extractable-P concentration was greater in the 015-cm depth of heavy $\left(154 \mathrm{mg} \mathrm{kg}^{-1}\right)$ than in medium $\left(138 \mathrm{mg} \mathrm{kg}^{-1}\right)$ or light-grazed $\left(127 \mathrm{mg} \mathrm{kg}^{-1}\right)$ paddocks and was higher under meadow bromegrass than under triticale. Given the large amounts of $\mathrm{NO}_{3}-\mathrm{N}$ in the heavy paddocks, there is potential for loss through both leaching and denitrification. Differences among treatments for $\mathrm{NH}_{4}-\mathrm{N}$, and $\mathrm{P}$ concentrations are not of particular concern environmentally, but are important from a fertility management point of view.

Funding for this research was provided by Canada-Alberta Environmentally Sustainable Agriculture Agreement. Support from Norwest labs, Edmonton, Alberta is greatly appreciated. We thank David Young, Chris Meyers, and Pascal Ogle for technical assistance and Dr. J.R. Robertson and Dr. J. Dormaar for critical review of the manuscript

Contribution No. 939

Manuscript accepted 8 Feb. 01.

\section{Resumen}

Debido a que el apacentamiento intensivo en las praderas húmedas del oeste Canadiense es nuevo hay poca información disponible sobre sus efectos en el estado de $\mathbf{N}$ y $P$ del suelo. Este estudio aborda la interrogante de los efectos de la intensidad del apacentamiento y especie de pradera en el estado de los macronutrientes en un suelo Typic Haplustoll en Lacombe, Alberta. Potreros de "Smooth bromegrass" (Bromus inermis Leyss.), "Meadow bromegrass" (Bromus riparius Rhem.) y "Winter triticale" ( $X$ Triticosecale Wittmack.), repetidos 4 veces, se sometieron a 3 intensidades de apacentamiento (fuerte, media y ligera, definida por la frecuencia y severidad de defoliación) utilizando vaquillas de año de ganado para carne. Anualmente, durante los años de producción, se aplicaron al voleo fertilizantes de Nitrógeno $(\mathrm{N}), \mathrm{P}$ y $\mathrm{K}$ en dosis de 100, 22, and $42 \mathrm{~kg} \mathrm{ha}^{-1}$. El experimento se mantuvo en los mismos potreros durante 4 años. En el año de establecimiento y en el tercer y cuarto año de producción se tomaron en de cada potrero muestras aleatorias de suelo a una profundidad de $60 \mathrm{~cm}$. La concentración de nitratos- $\mathrm{N}\left(\mathrm{NO}_{3}-\mathrm{N}\right)$, amonio- $\mathrm{N}$ $\left(\mathrm{NH}_{4}-\mathrm{N}\right.$ ), $\mathrm{N}$-mineral (la suma de $\mathrm{NO}_{3}-\mathrm{N}$ y $\mathrm{NH}_{4}-\mathrm{N}$ ), N-total Kjeldahl y $P$ extractable se determinó en las profundidades de 0-15, 15-30, 30-60, and 0-60-cm. En cada incremento de profundidad de suelo la concentración de nitratos fue mayor (1.7 a 2.4 veces) en el apacentamiento fuerte que en el apacentamiento ligero y la cantidad de nitratos en la profundidad de $0-60 \mathrm{~cm}$ fue 2.2 veces mayor en los potreros con apacentamiento fuerte. En la profundidad de 30-60 cm se midió más $\mathrm{NO}_{3}-\mathrm{N}$ bajo las especies perennes que bajo el "Triticale" (22.2 vs $13.6 \mathrm{mg} \mathrm{kg}^{-1}$, respectivamente). La cantidad de $\mathrm{N}$-amoniacal $(0-60 \mathrm{~cm})$ fue mayor en las praderas de "Bromegrass" (30 $\left.\mathrm{kg} \mathrm{ha}^{-1}\right)$ que en las "Triticale" (25 $\mathrm{kg} \mathrm{ha}^{-1}$ ), pero no mayor que en los potreros con "Smooth bromegrass" a la profundidad de $0-15-\mathrm{cm}$. La concentración de $P$ extractable en la profundidad de $0-15-\mathrm{cm}$ fue mayor en los potreros con apacentamiento fuerte $\left(154 \mathrm{mg} \mathrm{kg}^{-1}\right)$ que en los potreros con apacentamiento medio $\left(138 \mathrm{mg} \mathrm{kg}^{-1}\right)$ o ligero $(127 \mathrm{mg}$ $\mathrm{kg}^{-1}$ ) y fue mayor bajo la pradera que bajo de "Bromegrass" que bajo el "Triticale". Dadas las grandes cantidades de $\mathrm{NO}_{3}-\mathrm{N}$ en los potreros con apacentamiento fuerte hay potencial para perder $\mathbf{N}$ a través de lixiviación y denitrificación. Diferencias entre tratamientos en las concentraciones de $\mathrm{NH}_{4}-\mathrm{N}$, and $\mathrm{P}$ no son de preocupación ambiental particular, pero son importantes desde un punto de vista de manejo de la fertilidad del suelo.

Key Words: Ammonium, faeces, grazing intensity, macronutrient status, urine 
Intensive rotational grazing is well established in Europe, Australia, and New Zealand, but is still a novel practice on the Canadian prairies. Previous pasture research on the prairie parkland has focused on livestock and herbage responses to applied commercial fertilizer and was carried out at relatively low stocking densities (Doran et al. 1963, Elliot et al. 1961, Kopp et al. 1997). However, Nuttall et al. (1980) found economic returns from mixed alfalfagrass pastures maximized at $90 \mathrm{~kg} \mathrm{~N} \mathrm{ha}^{-1}$ and $20 \mathrm{~kg} \mathrm{P}^{-1}$ when stocking rate was 3.7 head ha-1. In the same study herbage yields increased with $\mathrm{N}$ applications up to $185 \mathrm{~kg}$ $\mathrm{N} \mathrm{ha}^{-1}$, but nitrate-N (NO3-N) accumulated in the $30-60-\mathrm{cm}$ depth of the soil profile. With the exception of the latter study none have reported residual soil macronutrient levels after grazing or studied the effects of varying grazing intensity (frequency and severity) on soil macronutrient status when a moderate level of commercial fertilizer is applied.

It is well known that grazing management affects nutrient cycling and net pools of nutrients in the soil (Haynes and Williams 1993, Whitehead 1995). Intensive pasture management tends to result in swards of relatively high nutritive value (Wedin 1996), which influences the nature and bioavailability of excreta (Haynes and Williams 1993, Mathews et al. 1996, Whitehead 1995). Nutrient cycling and pools of mineralized nutrients in soil are products of complex relationships among chemical, physical, and biological characteristics of the soil, sward composition, livestock species, type, and management, and climate (Haynes and Williams 1993). The processes involved are similar by geo-climatic region, but the net effects of nutrient cycling may vary from region to region. Grazing intensity regulates residual leaf area which influences pasture growth rate and therefore nutrient uptake (Briske and Heitschmidt 1991). In a short season area such as the parkland, early season pasture yields of perennial grasses are high relative to the late season, when cool temperatures and dry weather may slow or curtail growth. Efficient utilization of pastures through intensive grazing during the early season may cause a build-up of mineralized soil nutrients during the late summer and fall when plant growth and nutrient uptake is slow.

Different pasture species affect nutrient use and turnover due to seasonal timing of growth (Stout et al. 1997), root type, depth, carbon to nitrogen $(\mathrm{C}: \mathrm{N})$ ratio, and legume versus non-legume species composition (Wedin and Tilman 1990, Wedin 1996). Cool season grasses are widely used in pastures on the prairie parkland and when grown in rotational sequences with cereal and oil-seed crops, the average life of a stand is 5 years (Entz et al. 1995). Breaking or cultivation of forage stands to place them in annual-crop rotations results in the mineralization of large amounts of $\mathrm{N}$. Residual effects of this $\mathrm{N}$ on succeeding cereal crops have been demonstrated for up to 7 years (Hoyt and Leitch 1983). Pasturing annual species, such as Italian ryegrass (Lolium multiflorum Lam.) and spring-planted winter cereals (Baron et al. 1993) is of interest because of increased flexibility in land-use options on a year-toyear basis.

Concerns for ground water contamination from $\mathrm{NO}_{3}-\mathrm{N}$ (mostly related to manure application) arise when late-fall $\mathrm{NO}_{3}-\mathrm{N}$ accumulations exceed $160 \mathrm{~kg} \mathrm{ha}^{-1}$ in the upper $1.2 \mathrm{~m}$ of soil (Ewanek 1995). Similarly, losses of P by overland flow during snowmelt are a concern when extractable $\mathrm{P}$ levels exceed $330 \mathrm{~kg} \mathrm{ha}^{-1}$ in the upper $20-\mathrm{cm}$ of soil (Johnson and Eckert 1995). A knowledge of the relationship of late season accumulations of soil nutrients to grazing intensity may provide insights for improved grazing management, which could be both economically and environmentally prudent. The objective of this study was to determine the effect of grazing intensity and pasture grass species on late-season concentrations of mineralized-N and extractable-P over a 4-year period beginning with the establishment year of the perennial grasses.

\section{Materials and methods}

\section{Experiment establishment and pad- dock management}

A study was established in 1993 at the Lacombe Research Centre $\left(52^{\circ} 28^{\prime} \mathrm{N}\right.$; $113^{\circ} 45^{\prime} \mathrm{W} ; 847 \mathrm{~m}$ ) on a Penhold silt loam (coarse-loamy, mixed, frigid, Typic Haplustoll) soil. Complete details of the experimental layout have been published previously (Mapfumo et al. 2000). Historically, the site was a 15 -year-old extensively managed (low input) perennial grass pasture composed of smooth bromegrass (Bromus inermis Leyss.), quackgrass (Elytrigia repens L.), and Kentucky bluegrass (Poa pratensis L.). Cultivation of the site commenced in the summer of 1992 so that new species could be established in 1993. The first production year was 1994. Originally, 4 forage species treatments were established (Mapfumo et al. 2000); however, only 3 were continued until 1997. These were 'Carlton' smooth bromegrass, 'Paddock' meadow bromegrass (Bromus riparius Rhem.) and 'Pika' winter triticale ( $X$ Triticosecale Wittmack.). These 3 species treatments were combined in a factorial arrangement with 3 levels of grazing intensity ( 9 paddocks per replication). Treatments were laid out in $9 \mathrm{~m} \times 33 \mathrm{~m}$ paddocks in a randomized complete block design with 4 replicates.

Perennial grasses were seeded in the spring of 1993. Winter triticale paddocks were seeded annually, after cultivation, beginning in the spring of 1993. Prior to seeding all treatments in 1993, the experimental area received a broadcast application of $8,14,26$, and $5 \mathrm{~kg}$ ha- 1 of $\mathrm{N}, \mathrm{P}, \mathrm{K}$, and $\mathrm{S}$, respectively, followed by a light cultivation and packing. Smooth bromegrass and meadow bromegrass were broadcast-seeded at a rate of 11.2 and 16.8 $\mathrm{kg} \mathrm{ha}^{-1}$ respectively, mixed with $1 \mathrm{~kg} \mathrm{ha}^{-1}$ of 'Spredor II' alfalfa (Medicago sativa L.). Triticale was seeded at $135 \mathrm{~kg} \mathrm{ha}^{-1}$ with 2 passes of a plot seeder (packer wheels in front, double disk openers at 25$\mathrm{cm}$ row spacing and packer wheels behind) at an effective row spacing of 12.5 $\mathrm{cm}$. All seeding was followed immediately by harrowing and packing. All plots were hand weeded after establishment and were grazed 3 times in the fall of 1993. No tillage was done before winter on triticale plots. By the time of the current study in 1996 and 1997, there was almost no alfalfa remaining in the perennial paddocks. Each spring (1994 to 1997, inclusive) fertilizers to supply 100,22 , and $42 \mathrm{~kg} \mathrm{ha}^{-1}$ of $\mathrm{N}, \mathrm{P}$, and $\mathrm{K}$, respectively were broadcast over the experimental area. Triticale plots were rototilled and seeded as described above. The herbicide MCPA [(4-chloro-2methylphenoxy) acetic acid] was applied (600 g active ingredient (a.i.) ha ${ }^{-1}$ in 1994 to 1996 , and $900 \mathrm{~g}$ a.i. ha ${ }^{-1}$ in 1997 ) to the triticale plots to control weeds. No herbicide was applied in perennial grass plots.

\section{Grazing treatments}

Each paddock was fenced with wooden posts and high-tensile smooth wire that was electrified to contain cattle and prevent grazing of adjacent plots. From 1994 to 1997 , paddocks were grazed rotationally by yearling heifers, with 3 grazing intensities (represented by different pregrazing canopy heights) superimposed on each crop species. Canopy heights for grazing initiation were determined using the weighted disk method (Bransby et al. 1977). Target pre-grazing heights for perennial forages averaged 13, 17, and 26 $\mathrm{cm}$ for heavy, medium, and light grazing, respectively. Target heights for triticale 
Table 1. Summary of grazing treatments averaged over 1996 and 1997 at Lacombe, Alberta.

\begin{tabular}{|c|c|c|c|c|c|}
\hline $\begin{array}{l}\text { Crop and grazing } \\
\text { intensity }\end{array}$ & $\begin{array}{c}\text { Date of } \\
\text { initial } \\
\text { grazing }^{1}\end{array}$ & $\begin{array}{l}\text { Number of } \\
\text { grazing }\end{array}$ & $\begin{array}{c}\text { Mean rest } \\
\text { period }\end{array}$ & $\begin{array}{c}\text { Total } \\
\text { animal } \\
\text { days }\end{array}$ & Stocking rate \\
\hline & & (Days) & & & $\left(\right.$ AUM. ha $\left.{ }^{-1}\right)$ \\
\hline \multicolumn{6}{|c|}{ Smooth bromegrass } \\
\hline Heavy & 29 May & 6 & 22 & 29.5 & 26.5 \\
\hline Medium & 3 June & 4 & 24 & 18.9 & 17.0 \\
\hline Light & 10 June & 3 & 50 & 14.2 & 12.7 \\
\hline \multicolumn{6}{|c|}{ Meadow bromegrass } \\
\hline Heavy & 29 May & 5 & 22 & 23.5 & 21.1 \\
\hline Medium & 4 June & 3.5 & 23 & 14.3 & 12.8 \\
\hline Light & 11 June & 3 & 56 & 13.9 & 12.5 \\
\hline \multicolumn{6}{|l|}{ Triticale } \\
\hline Heavy & 10 July & 3.4 & 18 & 15.5 & 13.9 \\
\hline Medium & 14 July & 3 & 34 & 9.4 & 8.4 \\
\hline Light & 29 July & 2 & 49 & 5.7 & 5.1 \\
\hline
\end{tabular}

Date of first grazing varied for the 2 years. The date given is the mid-point between the 2 actual dates.

were 11,12 , and $21 \mathrm{~cm}$ for heavy, medium and light grazing respectively. These heights were used to maintain consistency, not to predict pasture yield. Approximately 84,73 , and $64 \%$ of annual production disappeared from heavy, medium and light grazing, respectively. Forage species and grazing parameters are given in Table 1. From 2 to 6 heifers were placed in a paddock at one time. Grazing time was measured in hours and calculated as animal days per paddock. Each grazing event was less than 24 hours.

\section{Soil sampling}

In addition to the soil sampling described by Mapfumo et al. (2000), samples were taken to monitor soil mineral-N and extractable $\mathrm{P}$ concentrations. Soil cores were taken from 3 random locations in each paddock (i.e. all grazing intensity $\times$ species $\times$ replicate combinations). Soil samples were taken in October of 1993 (establishment year), 1994, 1995, 1996, and 1997 to a depth of $60 \mathrm{~cm}$ using a hydraulically powered sampler with a 5.1$\mathrm{cm}$ diameter probe. Soil cores were sliced into depth segments of $0-15,15-30$ and $30-60 \mathrm{~cm}$ and bulked by depth.

In 1993, samples were bulked over replicates and grazing intensities, as the grazing intensity treatments were not initiated until 1994. In 1994 and 1995 samples were bulked over replicate, but not grazing intensity levels. In 1994 and 1995 soils were analysed for soil $\mathrm{NO}_{3}-\mathrm{N}$ and extractable-P (data not shown). Because of trends observed for soil $\mathrm{NO}_{3}-\mathrm{N}$ concentration with increasing grazing intensity in 1994 and 1995, more complete soil analyses were conducted for 1996 and 1997 data. Data for 1993 were used to deter- mine differences for soil mineral-N, and extractable-P concentrations between the fall of the establishment year and the fall of 1996 and 1997. The data (means) from 1993 were the same for all grazing intensities and replicates. The data for 1996 and 1997 were used to determine sequential year effects of treatments after 3 and 4 years of grazing, respectively.

All samples were transported from the field immediately, spread in shallow pans, and dried at room temperature in a forcedair dryer. Following drying, the samples were ground to pass a $2-\mathrm{mm}$ screen (Custom Laboratory Equipment Inc, Orange City, Fla). In October of 1996 and 1997, concentrations of $\mathrm{NH}_{4}-\mathrm{N}(\mathrm{KCl}$ extracted), $\mathrm{NO}_{3}-\mathrm{N}\left(\mathrm{CaCl}_{2}\right.$ extracted $)$, total Kjeldahl-N, and extractable P ("modified Kelowna" extract; Ashworth and Mrazek 1995) were determined using a Technicon autoanalyzer with industrial methods 79186T, 782-86T, 786-86T, and 792-86T, respectively (Technicon Industrial Systems Corp., Tarrytown, N.Y). Pool sizes of nutrients for respective depths were calculated by converting concentrations to quantities $\left(\mathrm{kg} \mathrm{ha}^{-1}\right)$ using bulk density determinations for each paddock. Bulk densities were determined using a Campbell Pacific Nuclear density/moisture probe. Three aluminium access tubes were installed in each paddock. Measurements were taken by lowering the probe down the access tube. Readings were taken at $15-\mathrm{cm}$ depth and thereafter at increments of $10 \mathrm{~cm}$. At each depth 2 readings were taken and used to calculate the average value for that depth. The calibration equation for the probe was used to calculate bulk density for the depth used and the standard count reflecting prevailing environmental conditions.

\section{Statistical analysis}

Initial data from 1993 were not analysed statistically within years, as replicates were not included. The following refers to the difference in $\mathrm{NO}_{3}-\mathrm{N}$ and extractable $\mathrm{P}$ concentrations between 1993 and 1996 and 1997 as well as $\mathrm{NH}_{4}-\mathrm{N}, \mathrm{NO}_{3}-\mathrm{N}$, mineral- $\mathrm{N}$ and extractable-P concentrations for 1996 and 1997. Data were subjected to analysis of variance using the SAS GLM procedure (SAS 1989) with a split-plot model. Grazing levels (GL) and species (S) were main plot effects tested for significance using replicates $(r e p) \times \mathrm{GL} \times \mathrm{S}$ as the error term, years (repeated measures) were a subplot tested with rep $\times$ year error term, and the interactions were tested with the residual error (Steel and Torrie 1980). Where the F-test indicated a significant $(\mathrm{P}<0.05)$ effect, means were separated by calculation of least significant differences (LSD) using the appropriate error mean squares. Single-degree of freedom comparisons (contrasts) were also used to determine differences between the perennial grasses and triticale.

\section{Results and Discussion}

\section{Post establishment soil nutrient con- centrations}

Soil nutrient concentrations were determined the year after cultivation of a longterm grass stand, in the fall of the establishment year, after a season of growth for the perennials and before grazing treatments had been imposed. The first nutrient concentration values (Table 2) included no variability for replicates, so only qualitative observations are valid. Nitrate-N $\left(\mathrm{NO}_{3}-\mathrm{N}\right)$ concentrations were high in the 0-6-cm depth under all species but were numerically 2 to 5 times higher under perennials than triticale at 15-30- and 30-60-cm depths. The extractable-P concentration for triticale was reduced slightly relative to the perennials at the $0-15-\mathrm{cm}$ depth. During the establishment year yield for species was not assessed, but visually the perennial stands were representative of seedling forage stands with dry matter production lower than triticale. Thus, a higher uptake of nutrients by the triticale compared to perennials could be expected.

Ferguson and Gorby (1971) observed that soil $\mathrm{NO}_{3}-\mathrm{N}$ pools on a similar soil, 1 year after cultivation of a grassland ranged from 90 to $135 \mathrm{~kg} \mathrm{ha}^{-1}(0-60 \mathrm{~cm})$ compared to $35 \mathrm{~kg} \mathrm{ha}^{-1}$ after a grain-grain fallow rotation when planted to wheat. Mineralization may release up to $200 \mathrm{~kg} \mathrm{~N}$ $\mathrm{ha}^{-1}$ when grasslands are cultivated 
Table 2. Concentrations of soil $\mathrm{NO}_{3}-\mathrm{N}$ and extractable-P in $0-15,15-30$, and 30-60-cm depths determined in the fall of the establishment year (1993) prior to imposition of grazing treatments at Lacombe, Alberta.

\begin{tabular}{lcc}
\hline \hline Species & \multicolumn{2}{c}{$\begin{array}{c}\text { Soil nutrient concentration } \\
\text { Extractable-P }\end{array}$} \\
\hline & $\mathrm{NO}_{3} \mathrm{~N}$ & 144 \\
\hline$-15 \mathrm{~cm}$ & & 147 \\
Smooth bromegrass & 40 & 118 \\
Meadow bromegrass & 36 & 136 \\
Triticale & 33 & \\
Mean & 36 & 41 \\
15-30 cm & & 39 \\
Smooth bromegrass & 40 & 33 \\
Meadow bromegrass & 33 & 38 \\
Triticale & 8 & \\
Mean & 27 & 14 \\
30-60-cm & & 21 \\
Smooth bromegrass & 32 & 15 \\
Meadow bromegrass & 28 & 17 \\
Triticale & 10 & \\
Mean & 23 & \\
\hline
\end{tabular}

(Whitehead 1995). Carry over effects $\left(\mathrm{NO}_{3}-\mathrm{N}\right)$ of grassland cultivation lasted approximately 2 years in the study of Ferguson and Gorby (1971).

\section{Changes in soil nutrient concentra- tions over time.}

Species effects were minimal and grazing intensity effects weren't significant in all depths for change in nutrient concentrations from 1993 to 1997 suggesting that changes over time were relatively similar among treatments. However, changes did occur. Nitrate $\left(\mathrm{NO}_{3}-\mathrm{N}\right)$ concentration decreased under smooth bromegrass and increased slightly under triticale in the $15-30-\mathrm{cm}$ depth and extractable-P concentration decreased more under meadow bromegrass than under smooth bromegrass or triticale in the 30-60-cm depth (Table 3).

Soil mineral-N status measured in the fall reflects the net supply as a result of pasture uptake, mineralization of organic matter, addition of fertilizer-nutrients, cycling of nutrients through cattle, as well as immobilization and losses (leaching and denitrification). Mapfumo et al. (2000) showed significant increases in total Kjeldahl-N concentration for the $0-5$ and

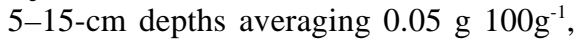
indicating $\mathrm{N}$-loss from the system may have been minimal. The extent of N-loss has not been determined under grassland

Table 3. Effect of forage species on changes in concentrations of soil $\mathrm{NO}_{3}-\mathrm{N}$, and extractable-P in 0-15, 15-30, and 30-60-cm depths, sampled in the fall after 4 years (1993 to 1997) of grazing at Lacombe, Alberta.

\begin{tabular}{lcc}
\hline \hline & \multicolumn{2}{c}{ Change in concentration } \\
Species & $\mathrm{NO}_{3}-\mathrm{N}$ & Extractable-P \\
\hline & & \\
$0-15 \mathrm{~cm}$ & -24.6 & 10.6 \\
Smooth bromegrass & -13.2 & -11.3 \\
Meadow bromegrass & -19.0 & 10.0 \\
Triticale & -18.8 & 2.9 \\
Mean & $\mathrm{ns}$ & $\mathrm{ns}$ \\
LSD 0.05 & \multicolumn{2}{c}{} \\
15-30 cm & -15.7 & 6.4 \\
Smooth bromegrass & -6.6 & 0.0 \\
Meadow bromegrass & 8.6 & -2.0 \\
Triticale & -4.3 & 1.3 \\
Mean & 21.4 & $\mathrm{~ns}$ \\
LSD 0.05 & & \\
$30-60 \mathrm{~cm}$ & -8.4 & -3.4 \\
Smooth bromegrass & -4.8 & -10.2 \\
Meadow bromegrass & 2.6 & -4.8 \\
Triticale & -3.4 & -6.2 \\
Mean & $\mathrm{ns}$ & 4.7 \\
LSD 0.05 & & \\
\hline
\end{tabular}

ns not significant $(\mathrm{P}<0.05)$.

in this geo-climatic area. However, the complexity involved and dynamics of exchanges between mineral and organic- $\mathrm{N}$ are large in a grazing system and explanation of possible N-loss from the system is beyond the scope of this study.

Post establishment soil $\mathrm{NO}_{3}-\mathrm{N}(15-30-\mathrm{cm})$ values were high for both perennials and low for triticale (Table 2). Growth of triticale lags about 6 weeks behind bromegrass in the spring. Over this period soil $\mathrm{NO}_{3}-\mathrm{N}$ could be leached downward in the soil profile for triticale. The net effect could have been a large decrease, due to plant uptake, for the perennial and a slight increase for the annual.

Extractable-P changed marginally over 4 years, increasing on average $2.9 \mathrm{mg} \mathrm{kg}^{-1}$ in the $0-15-\mathrm{cm}$ depth. Changes in extractable-P concentration in the soil profile seem to indicate plant uptake from the 30-60-cm depth, with subsequent cycling through the grazing animals and deposition on the surface. Because root weight of meadow bromegrass was 3 times that of triticale and $110 \%$ of smooth bromegrass in the $30-60-\mathrm{cm}$ soil layer (Baron et al. 1999) it may have been more effective in cycling $\mathrm{P}$.

\section{Soil nutrient concentration after 4 years of grazing}

Heavy grazing resulted in higher $\mathrm{NO}_{3}-\mathrm{N}$ and mineral- $\mathrm{N}$ concentrations in the $0-15$ $\mathrm{cm}$ and $15-30-\mathrm{cm}$ depths and greater amounts of $\mathrm{NO}_{3}-\mathrm{N}$ and mineral-N in the 0-60 cm depth than light grazing (Tables 4 and 5). The medium grazing intensity was intermediate for $\mathrm{NO}_{3}-\mathrm{N}$ and mineral-N concentrations at all depths, but was not significantly different from the other grazing intensities at the $0-15-\mathrm{cm}, 15-30-\mathrm{cm}$ and $30-60-\mathrm{cm}$ depths. However, heavy grazing had greater amounts of $\mathrm{NO}_{3}-\mathrm{N}$ than the other grazing intensities (including medium) in the $0-60-\mathrm{cm}$ depth (Table 5). Year did not interact significantly $(\mathrm{P}>0.05)$ with the other factors and grazing intensity did not interact significantly with species.

The positive relationship between grazing intensity and soil NO3-N concentration is consistent with observations of others (Haynes and Williams 1993, Whitehead 1995). While grazing intensities used in the heavy grazing treatment may be greater than used in practice, a concurrent study (Baron et al. 1999) indicated that the heavy grazing intensity resulted in $20 \%$ more dry matter disappearance, with only an $8 \%$ reduction in above ground net productivity compared to light grazing. In addition, herbage- $\mathrm{N}$ content positively affects $\mathrm{N}$ concentration of urine and the proportion of total-N excreted in urine (Haynes and Williams 1993, Whitehead 1995, Stout et 
Table 4. Mean concentrations of $\mathrm{NO}_{3}-\mathrm{N}, \mathrm{NH}_{4}-\mathrm{N}$, and mineral-N in $0-15,15-30$ and 30-60-cm soil depths sampled in the fall after third and fourth years (1996 and 1997) of rotational grazing at 3 grazing intensities at Lacombe, Alberta.

\begin{tabular}{|c|c|c|c|}
\hline Parameters & $\mathrm{NO}_{3}-\mathrm{N}$ & $\mathrm{NH}_{4}-\mathrm{N}$ & Mineral-N \\
\hline $\begin{array}{l}\text { Grazing intensity } \\
0-15 \mathrm{~cm}\end{array}$ & \multicolumn{3}{|c|}{ 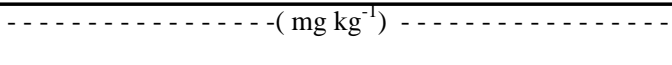 } \\
\hline Heavy & 44.3 & 9.3 & 53.6 \\
\hline Medium & 28.2 & 8.1 & 36.3 \\
\hline Light & 25.5 & 8.9 & 34.4 \\
\hline Mean & 32.7 & 8.8 & 41.5 \\
\hline $\mathrm{LSD}_{0.05}$ & 16.8 & $\mathrm{~ns}^{1}$ & 18.0 \\
\hline \multicolumn{4}{|l|}{$15-30 \mathrm{~cm}$} \\
\hline Heavy & 41.2 & 3.2 & 44.4 \\
\hline Medium & 21.8 & 4.0 & 25.9 \\
\hline Light & 17.4 & 3.8 & 21.2 \\
\hline Mean & 26.9 & 3.7 & 30.6 \\
\hline $\operatorname{LSD}_{0.05}$ & 22.7 & ns & 23.0 \\
\hline \multicolumn{4}{|l|}{$\underline{30-60 \mathrm{~cm}}$} \\
\hline Heavy & 27.9 & 3.0 & 30.7 \\
\hline Medium & 14.0 & 3.0 & 17.0 \\
\hline Light & 15.8 & 3.1 & 18.9 \\
\hline Mean & 19.3 & 3.0 & 22.3 \\
\hline $\mathrm{LSD}_{0.05}$ & ns & ns & ns \\
\hline
\end{tabular}

1ns not significant $(\mathrm{P}>0.05)$. Reasons for more $\mathrm{NH}_{4}-\mathrm{N}$ under meadow al. 1997). The mean herbage-N concentration $(2$ yr $\times 3$ species $)$ immediately prior to grazing was $34.4 \mathrm{~g} \mathrm{~kg}^{-1}$ and $27.9 \mathrm{~g} \mathrm{~kg}^{-1}$ for heavy and light grazing intensities, respectively (Baron et al. 1999). This is indicative of a greater nutrient turnover on heavy compared to light and medium grazing intensities. More $\mathrm{N}$ in urine form was deposited on heavy compared to light grazed treatments. Based solely on grazing time and animal density, estimated urine and faeces loading data indicate that the heavy grazing treatment was exposed to 2.4 times more excreta than the light grazing (Table 6). Thus, input sources of mineralized-N to the heavy grazed system had to be greater than the others; additions of fertilizer- $\mathrm{N}$ were similar for all treatments. On the well-drained site of the present

study, nitrification of urine would be rapid and denitrification minimal so one would expect to find most of the mineral- $\mathrm{N}$ in the $\mathrm{NO}_{3}$ form rather than the $\mathrm{NH}_{4}$ form, which was confirmed by the data (Table 5).

Ammonium-N concentration was not significantly affected by grazing intensity or species for any of the depths, but the amount of ammonium in the $0-60 \mathrm{~cm}$ depth under meadow bromegrass was higher than under triticale (Table 5). bromegrass than triticale are obscure, however the difference between the two species was small. The difference between the species for $\mathrm{NH}_{4}-\mathrm{N}$ amounts is not as simple as perennial vs. annual, because smooth bromegrass and triticale had similar amounts of soil $\mathrm{NH}_{4}-\mathrm{N}$. It is possible

Table 5. Mean amounts of $\mathrm{NO}_{3}-\mathrm{N}, \mathrm{NH}_{4}-\mathrm{N}$, and mineral-N in 0-60-cm soil depth sampled in the fall after third and fourth years (1996 and 1997) of rotational grazing of annual and perennial grass species at 3 grazing intensities at Lacombe, Alberta.

\begin{tabular}{lccc}
\hline \hline Parameters & $\mathrm{NO}_{3}-\mathrm{N}$ & $\mathrm{NH}_{4}-\mathrm{N}$ & Mineral-N \\
\hline Grazing intensity & 213 & 27.4 & 240 \\
\hline Heavy & 138 & 26.7 & 164 \\
Medium & 95 & 29.5 & 133 \\
Light & 148 & 27.8 & 179 \\
Mean & 74 & $\mathrm{~ns}$ & 76 \\
LSD 0.05 & & & \\
Species & 173 & 28.2 & 201 \\
Smooth bromegrass & 152 & 30.2 & 182 \\
Meadow bromegrass & $162^{*}$ & 29.2 & $192^{*}$ \\
Perennial mean & $122^{*}$ & 25.1 & 175 \\
Triticale & 147 & 27.8 & $\mathrm{~ns}$ \\
Overall mean & ns & 3.6 & \\
LSD 0.05 & & & \\
1 ns not significant $(\mathrm{P}>0.05)$ & &
\end{tabular}

that nitrification of $\mathrm{NH}_{4}-\mathrm{N}$ was reduced under meadow bromegrass compared to triticale and smooth bromegrass. Wedin and Tilman (1990) observed differences among species and reviewed literature, confirming variability among species for reduced nitrification. However, the higher $\mathrm{NH}_{4}-\mathrm{N}$ for meadow bromegrass should have been accompanied by lower soil $\mathrm{NO}_{3}-\mathrm{N}$, but this was not the case (Table $5)$. On the contrary there was a trend for more $\mathrm{NO}_{3}-\mathrm{N}$ for both perennials than triticale in the $0-60-\mathrm{cm}$ soil depth.

The species effect was not significant for $\mathrm{NO}_{3}-\mathrm{N}$ or mineral-N concentration for any depth. However, single-degree of freedom contrasts indicated $\mathrm{NO}_{3}-\mathrm{N}$ and mineral- $\mathrm{N}$ concentrations under the perennial grasses (22.2 and $25.2 \mathrm{mg} \mathrm{kg}^{-1}$, respectively) were greater than those under triticale (13.6 and $16.5 \mathrm{mg} \mathrm{kg}^{-1}$, respectively) in the $30-60-\mathrm{cm}$ depth. Amounts of NO3-N and mineral- $\mathrm{N}$ in the $0-60-\mathrm{cm}$ depth (Table 5) were greater under the perennial grasses than under triticale. This was likely due to a greater turnover of nitrogenous material by cattle. Annual aboveground net productivity for perennials averaged $130 \%$ of triticale (Baron et al 1999). While this should have positively influenced uptake of mineralized-N, it also resulted in more grazing days (Table 1). Estimated urine volume and faeces mass on the perennial paddocks was twice that of triticale (Table 6).

Amounts of $\mathrm{NO}_{3}-\mathrm{N}(0-60-\mathrm{cm})$ were higher in the present study than reported for other cropping systems used in the same region. Approximate residual $\mathrm{NO}_{3}-$ $\mathrm{N}$ levels taken in the fall under barley stubble and summerfallow (Malhi and Nyborg 1986) were $25 \%$ and $65 \%$, respectively of those found under light grazing (Table 5) with similar soils and fertilizer$\mathrm{N}$ applied to the barley. Also, amounts of $\mathrm{NO}_{3}-\mathrm{N}$ reported here were substantially higher than observed for extensively managed long term grasslands (Woodmansee et al. 1981). In long-term grasslands mineralization may be limited by low available soil moisture (Campbell et al. 1990), immobilization due to high organic residues and root masses (Woodmansee et al. 1981, Whitehead 1995, Wedin 1996) and large microbial biomasses. In a concurrent study using the same treatments surface soil moisture occasionally reached field capacity due to rainfall each summer (Twerdoff et al. 1999). Thus, low soil moisture did not likely limit mineralization of organic reserves over long periods and immobilization may not have been as large a factor as in extensively managed grasslands. 
Table 6. Estimated urine and faeces loading ${ }^{1}$ on rotationally grazed annual and perennial grass pastures with 3 grazing intensities at Lacombe, Alberta.

\begin{tabular}{lcc}
\hline \hline Parameters & Urine volume & Faeces mass \\
\hline Species & $\left(\right.$ litre $\left.\mathrm{ha}^{-1} \mathrm{yr}^{-1}\right)$ & $\left(\mathrm{kg} \mathrm{DM} \mathrm{ha}^{-1} \mathrm{yr}^{-1}\right)$ \\
Smooth bromegrass & 16852 & 1348 \\
Meadow bromegrass & 15720 & 1258 \\
Triticale & 8559 & 685 \\
Grazing intensity & & \\
Heavy & 18615 & 1489 \\
Medium & 10075 & 806 \\
Light & 7919 & 634 \\
\hline
\end{tabular}

${ }^{1}$ Based on average number of cow-days of grazing on each treatment over a 4-yr period and average daily volumes and masses of excreta for steers on pasture according to Whitehead (1993).

The levels of $\mathrm{NO}_{3}-\mathrm{N}$ found in the medium and heavy grazing treatments may be high enough to be of environmental concern. Ewanek (1995), in Manitoba, suggested a threshold of $160 \mathrm{~kg} \mathrm{ha}^{-1}$ in the top $1.2 \mathrm{~m}$ of soil as a level above which leaching might occur. Nitrate- $\mathrm{N}$ levels under heavy grazing exceeded $160 \mathrm{~kg} \mathrm{ha}^{-1}$ in the upper $60 \mathrm{~cm}$.

Extractable-P concentrations in the 0$15-\mathrm{cm}$ soil depth under heavy grazing, averaged across years and species, were higher than under medium or light grazing (154, 138, and $127 \mathrm{mg} \mathrm{kg}^{-1}$, respectively, LSD = 24). Roquette et al. (1973) found available soil-P increased by a factor of 3 after grazing coastal bermudagrass at 4.7 animal units $\mathrm{ha}^{-1}$ for 2 years. Differences in $\mathrm{P}$ levels among grazing intensities in the present study generally reflected levels of estimated excreta (Table 6). Phosphorus is excreted only in faeces and is not mobile (Haynes and Williams 1993). Therefore, higher $\mathrm{P}$ concentrations might be expected in a shallower depth (i.e., $0-5 \mathrm{~cm}$ ), than in the $0-15 \mathrm{~cm}$ layer sampled. Differences among species for $\mathrm{P}$ level were related to differences in animal grazing days between perennials and triticale.

\section{Summary}

Change of soil mineral-N and extractable-P concentration from establishment year until third and fourth production years were not related to grazing intensity. Total losses of soil NO3-N may have been minimal after cultivation and reestablishment since Mapfumo et al (2000) observed a net gain in total-N on surface soils in a related study. The changes observed for extractable-P indicated cycling from the $30-60-\mathrm{cm}$ soil depth to the surface by meadow bromegrass more than the other species.

During the third and fourth year after grazing was initiated, grazing intensity strongly influenced soil $\mathrm{NO}_{3}-\mathrm{N}$ levels down to the $60-\mathrm{cm}$ soil depth across all species. Soil $\mathrm{NO}_{3}-\mathrm{N}$ concentrations for heavy grazed treatments were 1.7-2.4 times greater than light grazed treatments. Amounts of residual soil $\mathrm{NO}_{3}-\mathrm{N}$ and mineral-N down to $60-\mathrm{cm}$ exceeded $200 \mathrm{~kg}$ $\mathrm{ha}^{-1}$ under heavy and approached $100 \mathrm{~kg}$ $\mathrm{ha}^{-1}$ under light grazing. Grazing intensities such as the heavy treatment are a potential risk to the environment as a result of leaching and denitrification, although this was not verified within the study. Amounts of mineral-N under medium and light grazing intensities are of less environmental concern, but were greater than those found under other cropping systems from nearly identical soils found in the region. Amounts of residual mineral-N found under these more normal grazing intensities indicate further research is necessary to improve $\mathrm{N}$ use efficiency under intensive grazing on the prairie parkland and that economic efficiencies may be gained through reduced fertilizer-N application. Phosphorus levels in the soil surface $(0-15 \mathrm{~cm})$ were not high enough to be of environmental concern, but economically, annual additions of P-fertilizer would not be practical.

\section{References}

Ashworth, J. and K. Mrazek. 1995. 'Modified Kelowna" test for available phosphorus and potassium in soil. Commun. Soil Sci. Plant Anal. 26:731-739.

Baron, V.S., E. Mapfumo, M.A. Naeth, and D.S. Chanasyk. 1999. Sustainable grazing systems for perennial and annual forages on sloped lands. Canada-Alberta Environmentally Sustainable Agr. Agreement Final Rep. RES-024-93, 161pp.

Baron, V.S., H.G. Nadja, D.F. Salmon, J.R. Pearen, and A.C. Dick. 1993. Cropping systems for spring and winter cereals under simulated pasture: yield and yield distribution. Can. J. Plant Sci. 73:703-712.
Bransby, D.I., A.G. Matches, and G.F. Krause. 1977. Disk meter for rapid estimation of herbage yield in grazing trials. Agron. J. 69:393-396.

Briske, D.D. and R.K. Heitschmidt. 1991. An ecological perspective, pp 7-28. In: Grazing Management: an Ecological Perspective. Eds. R.K. Heitschmidt and J.W. Stuth. Timber press, Portland, Ore.

Campbell, C.A., R.P. Zentner, H.H. Janzen, and K.E. Bowren. 1990. Crop rotation studies on the Canadian prairies. Research Branch, Agriculture Canada. Pub. No. 1841/E 133 p.

Doran, W.J., G.H. Bowman, and D.R. Walker. 1963. The productivity of fertilized pastures in central Alberta. Can. J. Plant Sci. 43:188-194.

Elliot, C.R., C.H. Anderson, and B.D. Owen. 1961. Studies with fertilized pastures on a heavy textured soil in Northern Alberta. Can. J. Plant Sci. 41:261-267.

Entz, M. H., W.J. Bullied, and F. KatepaMupondwa. 1995. Rotational benefits of forage crops in Canadian Prairie cropping systems. J. Prod. Agr. 8:521-529.

Ewanek, J. 1995. Survey of nitrate-nitrogen in the soil profile under different field management practices in Manitoba. In: Agriculture impacts on water quality. Proc. of a Western Canada Symp. Red Deer, Alberta, Feb. 21-22, 1995.

Ferguson, W.S. and B.J. Gorby. 1971. Effect of various periods of seed down to alfalfa and bromegrass on soil nitrogen. Can. J. Soil. Sci. 51:65-73.

Haynes, R.J. and P.H. Williams. 1993. Nutrient cycling and soil fertility in the grazed pasture ecosystem. Adv. in Agron. 49:119-199.

Hoyt, P.B. and R.H. Leitch. 1983. Effects of forage legume species on soil moisture, nitrogen and yield of succeeding barley crops. Can. J. Soil Sci. 63:125-136.

Johnson, J. and D. Eckert 1995. Best management practices: land application of animal manure. The Ohio State University Extension Agronomy facts. AGF - 208-95, 1995. $10 \mathrm{pp}$.

Kopp, J.C., W.P. McCaughey, and K.M. Wittenburg. 1997. Cow-calf production response to pasture forage species. XVIII Int. Grassl. Congress 29:37-38.

Malhi, S.S. and M. Nyborg. 1986. Increase in mineral $\mathrm{N}$ in soils during winter and loss of mineral $\mathrm{N}$ during early spring in North-central Alberta. Can. J. Soil Sci. 66:397-409.

Mapfumo, E., D.S. Chansyk, M.A. Naeth, and V.S. Baron. 2000. Grazing impacts on selected soil parameters under short term forage sequences. J. Range. Manage. 53:466-470.

Mathews, B.W., L.E. Sollenberger, and J.P.Tritschler II. 1996. Grazing systems and spatial distribution of nutrients in pastures Soil considerations. pp 213-229. In: Nutrient Cycling in Forage Systems. Proc. Sym. March 7-8, 1996 Columbia, Mo. Eds. R.E. Joost and C.A. Roberts. Potash and Phosphate Institute. and the Foundation for Agron. Res., Manhattan, Kan. 
Nuttall, W.F., D.A. Cooke, J. Waddington, and J.A. Robertson. 1980. Effect of nitrogen and phosphorus fertilizers on a bromegrass and alfalfa mixture grown under two systems of pasture management. I. Yield, percentage legume in sward, and soil tests. Agron J. 72:289-298.

Roquette, F.M. Jr., J.E. Matocha, and R.L. Duble. 1973. Recycling and recovery of nitrogen, phosphorus and potassium by coastal bermudagrass. II. Under grazing conditions with two stocking rates. J. Environ. Qual., 2:129-132.

SAS Institute 1989 SAS/STAT user's guide Version $6,4^{\text {th }}$ Edition. SAS Institute, Cary, N.C.

Steel, R.G.D. and J.H. Torrie. 1980. Principles and Procedure of Statistics. A Biometrical Approach. $2^{\text {nd }}$ Ed. McGraw-Hill Book Company, New York, N.Y. 633p.
Stout, W.L., S.A. Fales, L.D. Muller, R.R. Schnabel, W.E. Priddy, and G.F. Elwinger. 1997. Nitrate leaching from cattle urine and faeces in Northeast USA. Soil Sci. Soc. Amer. J. 61:1787-1794.

Twerdoff, D.A., D.S. Chanasyk, E. Mapfumo, M.A. Naeth, and V.S. Baron. 1999. Soil water regimes under rotational grazing of annual and perennial forages. Can. J. Soil Sci.79: 627-637.

Wedin, D.A. 1996. Nutrient cycling in grasslands: An ecologists perspective. pp 29-44. In: Nutrient Cycling in Forage Systems. Proc. Sym. March 7-8, 1996 Columbia, MO. Eds. R.E. Joost and C.A. Roberts. Potash and Phosphate Institute and the Foundation for Agron. Res., Manhattan, Kan.
Wedin, D.A. and D. Tilman. 1990. Species effects on nitrogen cycling: a test with perennial grasses. Oecologia 84:433-441.

Whitehead, D.C. 1995. Amounts, sources and fractionation of organic nitrogen in soils. pp. 82-107. In: Grassland nitrogen. Ed. D.C. Whitehead. CAB International, Wallingford, Oxon, U.K.

Woodmansee, R.G., I. Vallis, and J.J. Mott. 1981. Grassland nitrogen. F.E. Clark and T. Rosswall (eds). Terrestrial Nitrogen Cycles. Ecol. Bull. (Stockholm) 33:443-462.

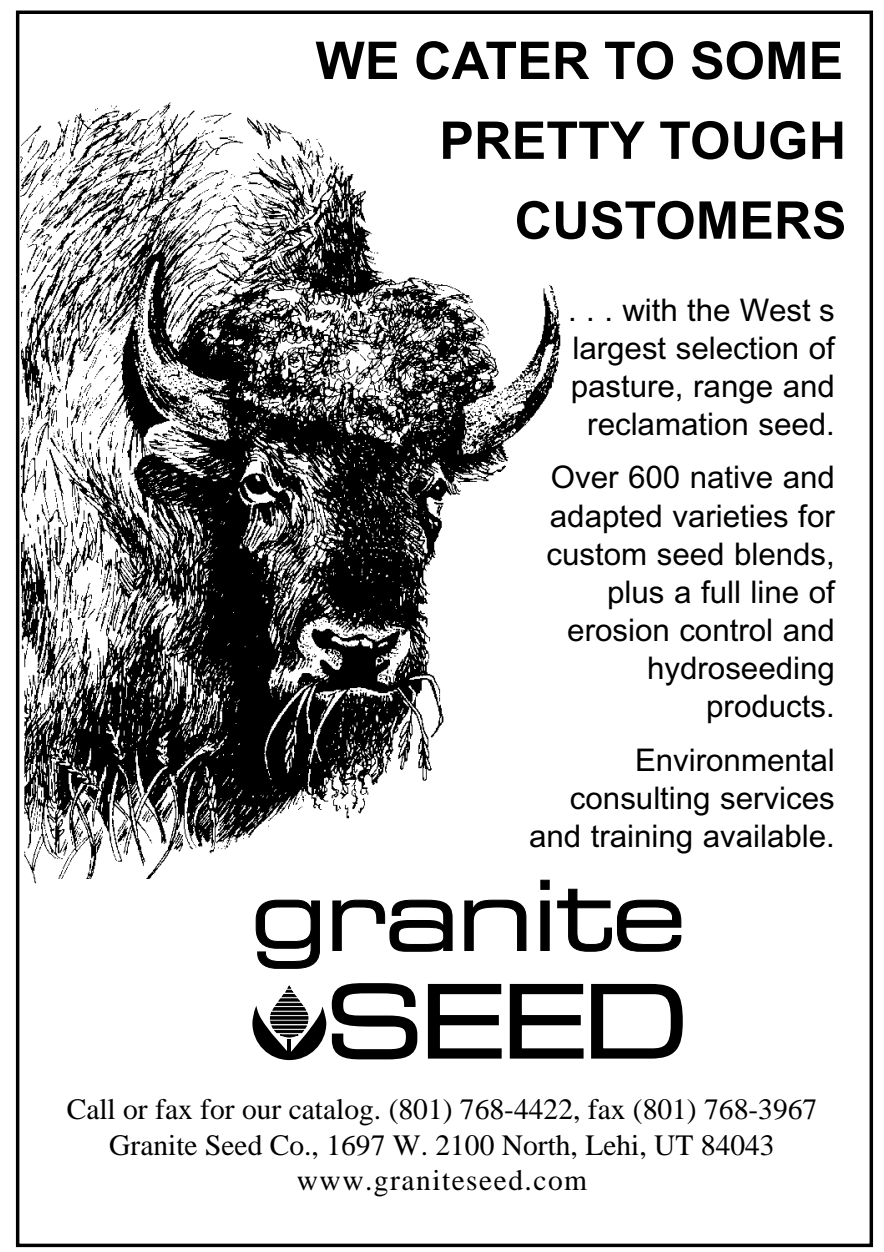




\title{
Tracked vehicle impacts to vegetation structure and soil erodibility
}

\author{
WILLIAM P. GRANTHAM, EDWARD F. REDENTE, CALVIN F. BAGLEY, AND MARK W. PASCHKE
}

Authors are graduate research assistant and professor, Department of Rangeland Ecosystem Science; associate director, Center for Ecological Management of Military Lands (CEMML); and research scientist, Department of Rangeland Ecosystem Science, Colorado State University, Fort Collins, Colo. 80523.

\begin{abstract}
There has been increasing concern that training on military lands results in excessive soil erosion, ecosystem degradation, and loss of sustainable training resources. Vegetation structure has been shown to play a role in soil surface stabilization by reducing shear stress caused by wind force. A study at the Idaho Army National Guard training facility at Orchard Training Area (OTA), Ida. assessed the effect of simulated M1A2 Abrams battletank maneuvers on grassland plant canopies and soil erodibility. The point-intercept method was used to estimate vertical vegetation structure before and after tracking. A portable wind tunnel was used to measure threshold wind speeds (TWS) associated with different numbers of tank passes and soil mass removed by wind. Results indicated that significant damage occurred to vertical vegetation structure as the number of passes increased. Threshold wind speed, an indicator of soil surface stability, significantly decreased with tracking and eroded soil mass significantly increased. Positive correlations existed between vegetation parameters and threshold wind speed. Soil loss was negatively correlated with vegetation parameters. Results indicated that the decrease of vertical vegetation structure led to a decrease in threshold wind speed. This decrease in threshold wind speed was the result of reduced soil surface protection by vegetation. Decreased surface protection also resulted in increased soil loss. Results from this work confirmed that vegetation plays a major role in reducing shear stress on the soil surface. Predictions for soil loss at Orchard Training Area resulting from the number of M1A2 passes are made using linear models. A critical tracking threshold of 4 passes was estimated based upon model output and average local wind speeds for Orchard Training Area.
\end{abstract}

Key Words: Erosion, threshold friction velocity, threshold wind speed, arid lands, surface roughness, military lands, wind tunnels

Wind erosion typically removes the most productive layers of the soil from the upper surface horizons. Loss of soil from the upper horizons has the potential to reduce productivity, change vegetation species composition, degrade land conditions, and contribute to increased rates of desertification. There has been

Research was funded through the Center for Ecological Management of Military Lands (CEMML), by the Idaho Army National Guard, the U.S. Army Corps of Engineers Construction Engineering Laboratory, and the U.S. Forest Service Rocky Mountain Experiment Station.

Manuscript accepted 8 Dec. 2000

\section{Resumen}

Ha habido una preocupación creciente respecto a que el entrenamiento en campos militares resulte en una excesiva erosión de suelo, degradación de los ecosistemas y perdida de los recursos sustentables de entrenamiento. La estructura de la vegetación ha mostrado jugar un papel en la estabilización de la superficie del suelo al reducir el estrés cortante causado por la fuerza del viento. Un estudio realizado en el área "Orchard" (AEO) de las instalaciones de entrenamiento de la Guardia Nacional situadas en Idaho evaluó el efecto de maniobras simuladas del tanque de batalla MIA2 Abrams sobre la copa de las plantas de pastizal y la susceptibilidad a erosión del suelo. Se utilizo el método de intercepción de puntos para estimar la estructura vertical de la vegetación antes y después del paso de los tanques. Un túnel de viento portátil se utilizó para medir el umbral de la velocidad del viento (UVV) asociado con diferentes números de pasos del tanque y la masa de suelo removida por el viento. Los resultados indican que conforme el número de pasos aumento ocurrió un daño significativo de Ia estructura vertical de la vegetación. El umbral de la velocidad del viento, un indicador de la estabilidad de la superficie del suelo, disminuyo significativamente con el paso de los tanques y la masa de suelo erosionado aumento significativamente. Existieron correlaciones positivas entre los parámetros de la vegetación y los umbrales de velocidad del viento. La pérdida de suelo se correlaciono negativamente con los parámetros de la vegetación. Los resultados indican que la disminución en la estructura vertical de la vegetación conduce a una disminución del umbral de la velocidad del viento. Esta disminución en el umbral de la velocidad del viento fue el resultado de una reducida protección de la superficie del suelo por la vegetación lo que también resultó en un incremento de pérdida de suelo. Los resultados de este trabajo confirman que la vegetación juega un papel principal en reducir el estrés cortante en la superficie del suelo. Las predicciones para la perdida de suelo en el área de entrenamiento "Orchard" resultantes del número de pasos del MIA2 son hechas utilizando modelos lineales. Se estimo un umbral crítico de 4 pasos de tanque, el cual fue basado en el modelo resultante y el promedio local de velocidad del viento de la área de entrenamiento "Orchard".

increasing concern that training activities on military lands result in excessive soil erosion, ecosystem degradation, and loss of sustainable training resources. The National Environmental Policy Act of 1969 (NEPA) requires that the Army minimize ecological impacts caused by military training activities to the 4.8 million 
hectares of land for which it is responsible. Soil conservation is a critical first step for maintaining ecosystem productivity.

Wind erosion of soils occurs when the force of drag is sufficient to overcome the forces holding soil particles in place such as gravity, soil moisture, and surface crust aggregation (Bagnold 1941). The term threshold friction velocity (TFV), which corresponds to the minimum surface drag associated with a wind velocity at a particular height needed to overcome forces holding soil particles in place, originated from Bagnold's work and is used as an indicator of soil surface stability (Bagnold 1941). Estimation of dust production, wind erosion, and soil surface stability relies heavily on values of TFV (Gillette et al. 1980) and is influenced by the amount of surface roughness present (Marshall 1971, Gillette 1988, Gillette and Stockton 1989, Stockton and Gillette 1990, Musick and Gillette 1990). Threshold friction velocities and the effects of roughness elements have been determined experimentally by several investigators with the use of laboratory wind tunnels (Bagnold 1941, Chepil 1945, Iversen et al. 1973, Wood et al. 1974, Phillips 1980). Threshold wind speed is a similar indicator of soil surface stability, which refers to the speed at a particular height above the soil surface at which soil particle entrainment begins. Experiments examining soil loss have been done by inserting soil traps or filters at the rear of wind tunnels to capture eroding particles (Chepil 1956, Lyles and Schrandt 1974, Fryrear 1985, Findlater et al. 1990, Williams et al. 1995).

Previous work using wind tunnels, soil traps, and field observations has shown that surface crusting on the soil surface and vertical vegetation structure act as aerodynamic roughness elements. Marshall (1971), Gillette and Stockton (1989), Musick and Gillette (1990), and Raupach et al. (1993) concluded that vertical vegetation structure acts as an aerodynamic roughness element with respect to the airstream. Their work indicated that overall shear stress caused by wind passing over a roughened surface is partitioned between stress on the roughness elements and stress on the soil surface. These individual elements decrease the wind stress on the erodible surface by absorbing a significant portion of the downward momentum flux from the airflow above.

The purpose of this research was to assess the effect of military training equipment on vegetation structure and subsequent erodibility of soils. The specific objectives of this study were to: 1) quanti- fy how the M1A2 Abrams battletank impacts the vegetation structure of semiarid grasslands and how this may contribute to increased wind erodibility of soils, and 2) determine if a critical tracking threshold exists that significantly decreases surface stability and increases soil loss. Within the framework of these objectives we tested 2 hypotheses: 1) tracked and non-tracked sites will have differences in bare ground, ground covered by litter, vertical vegetation structure, threshold wind speed, and amount of soil removed, and 2) tracking intensities will produce significant differences in bare ground, ground covered by litter, vertical vegetation structure, threshold wind speed, and amount of soil removed.

\section{Materials and Methods}

\section{Site Description}

Research was conducted at the Idaho Army National Guard (IDARNG) training facilities at Orchard Training Area, Ida (OTA). This is an Army National Guard Training facility located in southwestern Idaho on the Snake River Plain $\left(43^{\circ} 18.9^{\prime}\right.$ $\mathrm{N}, 116^{\circ} 01.7^{\prime} \mathrm{W}$ ) which currently experiences soil losses during and following training activities. This soil loss is an ecological concern as well as a safety issue. Dust storms from disturbed soils reduce visibility and hamper training activities. The soils in the area are aridisols that developed in loess or silty alluvium deposited over basalt plains.

\section{Experimental Design}

A complete randomized block design was used to study the impacts of M1A2 maneuvers on the vegetation and soil surface. Three blocks were selected within the northern vegetation zone of Orchard Training Area for each of the randomized blocks. The locations for the blocks were based on similarity in soil surface texture, homogeneity in vegetation structure, and lack of previous tracked vehicle disturbance. Each block measured 100 meters long, 50 meters wide, and contained 5 treatments.

Tracking treatments were applied in all 3 blocks in August 1996 to simulate tracked vehicle maneuvers. The treatments consisted of a control, which received no passes, and treatments, which received 1 , 2,4 , or 8 consecutive passes. Each M1 pass was straight and occurred at approximately 30 miles per hour. Turns were not simulated. Specifications for the M1 are shown in Table 1.
Table 1. Vehicle specifications for the M1A2 (Foss 1988).

\begin{tabular}{lc}
\hline \hline Category & Specifications \\
\hline Crew & 4 \\
Combat Weight & $57,154 \mathrm{~kg}$ \\
Ground Pressure & $0.96 \mathrm{~kg} \mathrm{~cm}^{-2}$ \\
Length & $7.9 \mathrm{~m}$ \\
Ground Clearance & hull center $-0.48 \mathrm{~m}$ \\
& hull sides $-0.43 \mathrm{~m}$ \\
Single Track Width & $0.64 \mathrm{~m}$ \\
\hline
\end{tabular}

Vegetation sampling was conducted in July and August 1996. Four vegetation parameters were measured pre- and posttracking to document the baseline vegetation and soil surface conditions. The 4 vegetation parameters measured were percent cover by species, fractional bare ground, fractional litter cover, and fractional aerial intercept per plot. Each treatment within a given block was designated as a plot. Within each of these plots, two, 50-meter transects were located within the area that was to be impacted by the M1 treads. Each-50 meter transect was sampled using the point-intercept method as described by Bonham (1989) at 1-meter intervals.

A portable wind tunnel was used to measure threshold wind speed and soil loss. Threshold wind speed is defined as the wind speed $\left.(\mathrm{m} \mathrm{sec})^{-1}\right)$ at a particular height above the soil surface at which soil particle entrainment within the airstream is observable. It is also used as an indicator of soil surface stability. Soil loss was estimated with the use of inline filters inserted at the rear of the wind tunnel. These filters trapped soil and litter particles removed from the surface by the wind stream which were later separated into litter and soil components and weighed. It should also be noted that the fine dust component of the sampled soils was not captured by the furnace filters and was not quantified.

Wind Tunnel Design: The portable wind tunnel used was the same as the one described by Gillette (1978), Gillette et al. (1980), Williams et al. (1995), and similar to that used by Marticorena et al., (1997). This open-floored wind tunnel was built so that a variable speed turbulent boundary layer could be formed over a flat soil containing small-scale roughness elements. The wind tunnel used a 2-dimensional, 5:1 contraction section with a honeycomb flow straightener, a working section where wind speed was measured, a rectangular diffuser chamber, and a filter box. Dimensions of the cross section of the working section were $15.24 \mathrm{~cm} \times$ $15.24 \mathrm{~cm}$ and the length was $300.5 \mathrm{~cm}$. 
Wind speed was measured with a pitot tube located $20 \mathrm{~cm}$ from the rear of the working section. The filter box was $33 \mathrm{x}$ $33 \mathrm{~cm}$ and contained 2 filters of different densities held in place by metal grates and was located at the rear of the expansion chamber. The filter material consisted of $30 \times 30-\mathrm{cm}$ fine furnace filter and coarse furnace filter to capture litter and soil removed from the surface.

Wind tunnel tests were performed after tracking. A wind tunnel trial consisted of the threshold wind speed measurements and the soil removal measurements. Threshold wind speed tests were measured first by placing the wind tunnel on the plo and slowly increasing the wind speed within the working section until particle entrainment was visible. The wind speed was then held constant while wind velocity measurements were taken at 5 consistent heights at the rear of the tunnel. These heights were at the surface, $37.5 \mathrm{~mm}, 75$ $\mathrm{mm}, 112.5 \mathrm{~mm}$, and $150 \mathrm{~mm}$ above the soil surface. Threshold wind speed measurements from the $75 \mathrm{~mm}$ height were used as threshold wind speed data for this study.

The wind speed was then increased to the full capacity of the wind tunnel and held constant for 5 minutes to collect removable surface material in the inline filters. The wind tunnel was then shut down. The filters containing wind blown litter and soil were collected and placed into a bag. The bagged filters were taken to a laboratory where collected soil was shaken out of the filters, litter components were picked from the filters, and materials in the bag were combined and weighed. Wind blown litter and soil were then sieved into 3 size classes and weighed separately. These size classes were coarse litter, fine material (fine litter and coarse soil fragments), and soil. This procedure was repeated for all 150 plots ( 3 blocks $\times 5$ treatments $\times 10$ wind tumnel plots).

\section{Statistical Analysis \\ Vegetation Parameters}

Pre-tracking multiple comparisons of parameter means were done to determine if vegetation measurements were homogeneous among blocks and among treatments. It was found that there were significant pre-tracking differences among blocks for species composition and fractional aerial intercept. This prompted the examination of the change in each vegetation parameter that resulted from a treatment instead of just an examination of post-tracking vegetation parameters. Posttracking fractional aerial intercept was

Table 2. Percent cover by species for total study site and by block.

\begin{tabular}{|c|c|c|c|c|c|}
\hline Species & Lifeform $^{1}$ & Overall & Block 1 & Block 2 & Block 3 \\
\hline & \multicolumn{5}{|c|}{$(\ldots \ldots \ldots$ (\% cover $) \cdots \ldots \ldots$} \\
\hline Bromus tectorum & IAG & 18 & 23 & 14 & 22 \\
\hline Epilobium paniculatum & NAF & 13 & 13 & 21 & 5 \\
\hline Lagophylla ramosissima & NAF & $<1$ & 1 & 0 & 0 \\
\hline Lepidium perfoliatum & IAF & 18 & 16 & 16 & 27 \\
\hline Poa secunda & NPG & 23 & 16 & 18 & 0 \\
\hline Ranunculus testiculatus & IAF & 4 & $<1$ & $<1$ & 14 \\
\hline Salsola kali & IAF & 5 & 0 & 0 & 20 \\
\hline Sitanion hystrix & NPG & 7 & 4 & 10 & 11 \\
\hline Vulpia octoflora & $\mathrm{NAG}$ & 16 & 26 & 22 & 0 \\
\hline
\end{tabular}

${ }^{1} \mathrm{NPG}=$ native perennial grass, $\mathrm{NAG}=$ native annual grass, $\mathrm{IPG}=$ introduced perennial grass, $\mathrm{IAG}=$ introduced annua grass, NPF = native perennial forb, NAF = native annual forb, IPF = introduced perennial forb, LAF = introduced annual forb.

subtracted from pre-tracking fractional aerial intercept and then subtracted from 1 to quantify the amount of vertical vegetation structure remaining after tracking. This procedure was done to reduce the influence of pre-tracking block and treatment differences in fractional aerial intercept. The results of the post-tracking correlations indicated that the block effects were adequately controlled to allow for a valid comparison of treatment effects. This term shall simply be known as fractional aerial intercept.

\section{Threshold Wind Speed}

The mean threshold wind speed was measured for each treatment at a height of $75 \mathrm{~mm}$. A Mixed Effects Model for Analysis of Variance (hereafter known as the Mixed Effects Model) was used with the General Linear Models procedure (GLM) in the SAS/STAT Version 6.12 (SAS Institute Inc. 1990) to compare differences in treatment means for threshold wind speed. Regression analysis was used to examine the effects of fractional aerial intercept on threshold wind speed.

\section{Surface Material Removal}

The amount of soil and litter removed by the wind stream was estimated from the mass of soil and litter captured by the inline filters at the rear of the wind tunnel. Total removed material mass, coarse litter mass, fine material mass, and soil mass were modeled versus treatment to examine the effect of tracking on these soil surface features. Regression analysis was used to examine the effects of fractional aerial intercept on total removed material mass.

\section{Correlations}

Post-tracking correlations were done to examine changes in vegetation parameters versus number of passes. Correlations were also done to determine if relation- ships existed between vegetation parameters and threshold wind speed. Specific correlations examined for these were: threshold wind speed versus number of passes, block effects, and fractional aerial intercept.

\section{Results}

\section{Community Composition}

The species composition for the study site was dominated by annual and perennial grasses and annual forbs from 0.1 meters to 0.3 meters in height. Mean plant cover in the study area was $30 \%$ native perennial grasses, $16 \%$ annual native grasses, $18 \%$ exotic annual grasses, $13 \%$ native annual forbs, and $18 \%$ exotic annual forbs (Table 2).

\section{Post-Tracking Comparisons}

Figure 1 shows the results of the posttracking comparisons. A single pass with the M1 did not significantly reduce fractional aerial intercept. However, multiple passes of 2,4 , and 8 resulted in significant reductions in fractional aerial intercept when compared to the control and 1 pass. In addition, the treatment with 8 passes had significantly less fractional aerial intercept than 2 passes.

\section{Threshold Wind Speed}

Results indicated that increasing number of vehicle passes resulted in significant decreases in threshold wind speed for each treatment (Fig. 2). Particle entrainment into the air stream was not achieved for untracked areas, even at the highest wind speeds attainable by the wind tunnel.

Predictive models were developed using regression analysis to examine the effect of post-tracking vegetation parameters on threshold wind speed. Post-tracking fractional aerial intercept was modeled with 


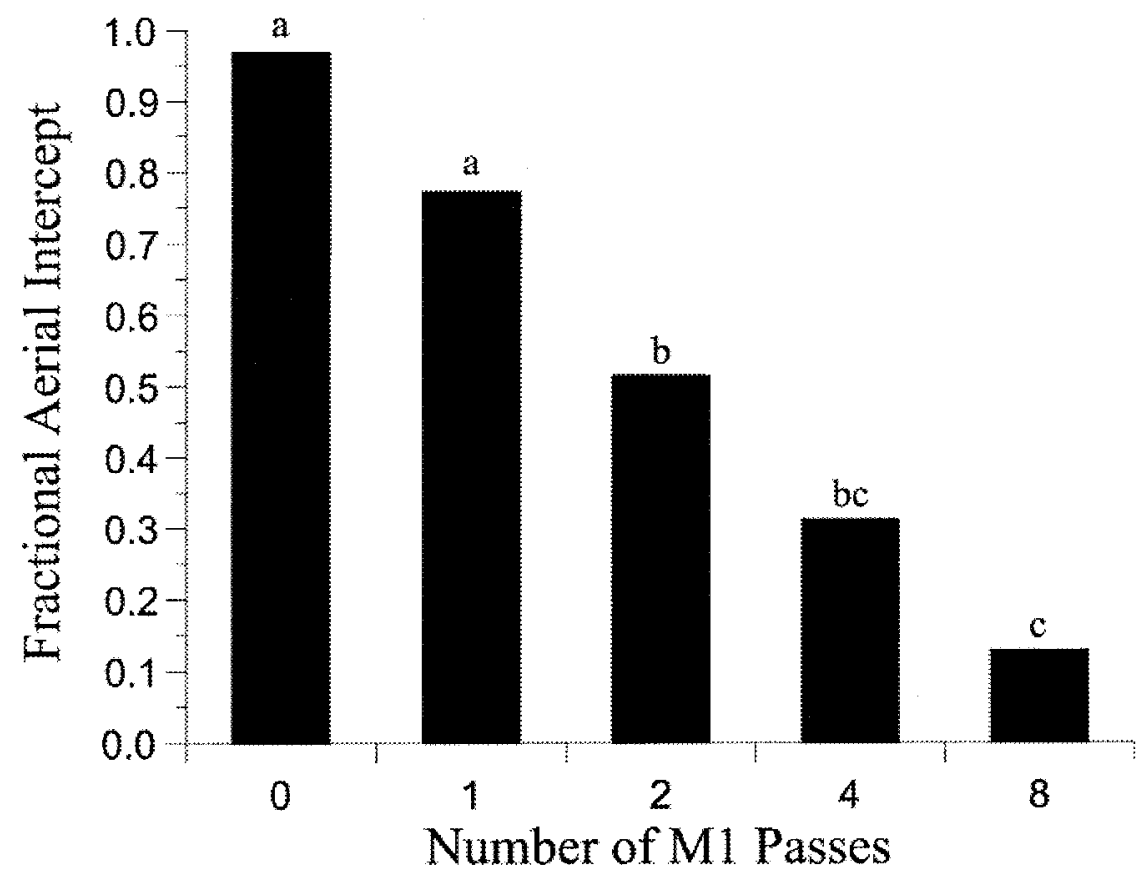

Fig. 1. Post-tracking fractional aerial intercept. The same letter indicates no significant differences at $p \leq 0.05(n=15)$.

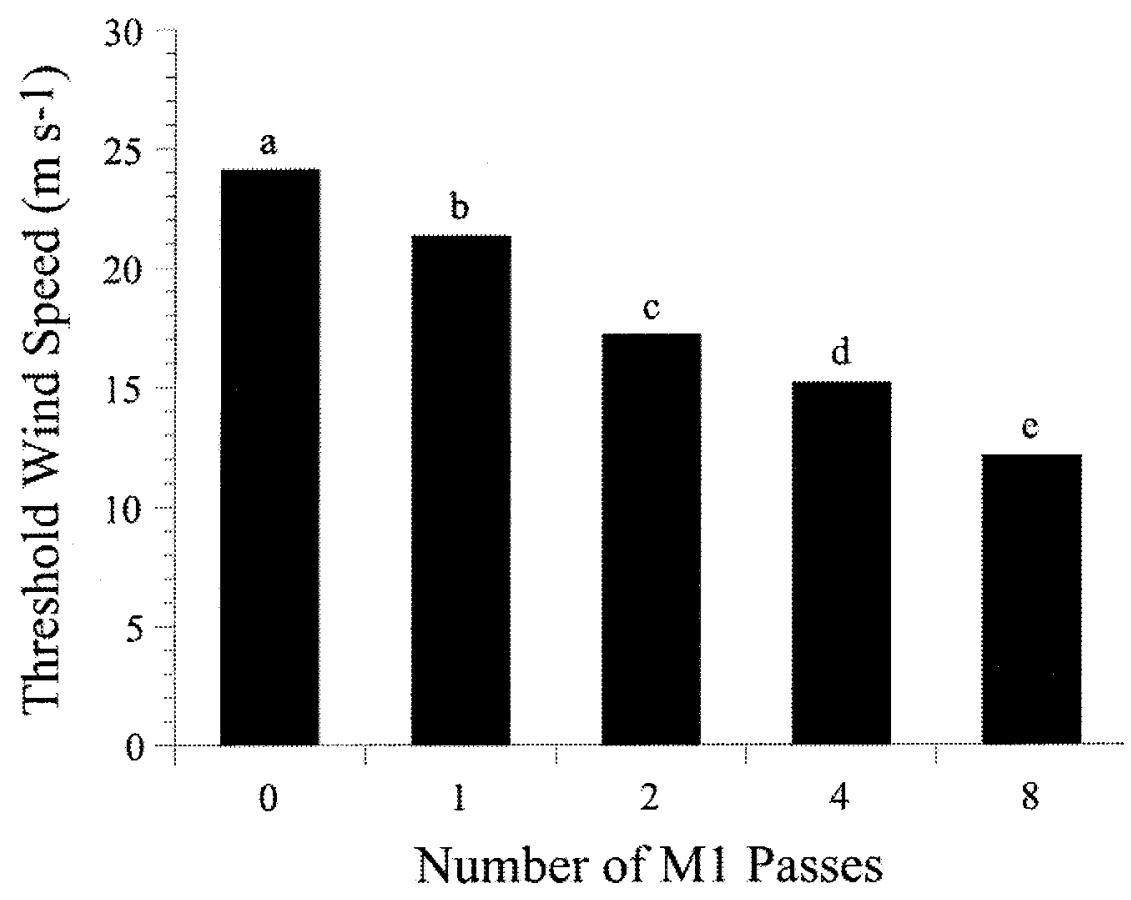

Fig. 2. Mean threshold wind speeds. The same letter indicates no significant differences at $p$ $\leq 0.05(n=150)$. threshold wind speed. The model for the effect of fractional aerial intercept predicts that threshold wind speed increases with an increase in fractional aerial intercept (FAI):

Threshold Wind Speed $\left(\mathrm{m} \mathrm{sec}^{-1}\right)=$ $11.53+13.42$ (FAI) $\mathrm{R}^{2}=0.87$

\section{Soil Removal}

Results from the material mass measurements indicated that as the number of M1 passes increased, the total mass of removed material significantly increased (Fig. 3). However, after sieving the total removed material into coarse litter, fine material, and soil size classes, it was found that each size class did not follow this pattern. Examination of the trend in the mass of the coarse litter portion showed that 1 and 2 passes resulted in significantly higher mass of coarse litter removed compared to the untracked area. Four and 8 passes did not significantly increase coarse litter mass above the mass associated with 2 passes but were significantly higher than 0 and 1 pass. One, 2, and 4 passes resulted in significantly greater fine material mass compared with no tracking. Fine material was highest after 8 passes. The mass of the soil portion was also successively greater as the number of passes increased.

Predictive models were also developed using regression analysis to examine the effects of fractional acrial intercept on total mass of removed material. Total removed material mass is predicted to decrease as fractional aerial intercept increases:

$$
\begin{aligned}
& \text { Total Removed Material Mass } \\
& \left(\mathrm{g} / 0.46 \mathrm{~m}^{2}\right)^{1}=173.74-186.03(\mathrm{FAI}) \\
& \mathrm{R}^{2}=0.93
\end{aligned}
$$

\section{Potential Soil Loss for Orchard Training Area}

Potential soil loss resulting from simulated tracking were developed and are shown in Table 3 . These predictions pertain to level grassland areas similar to the area used for this study. These predictions are based upon the wind speed of $24 \mathrm{~m}$ $\sec ^{-1}$ at $75 \mathrm{~mm}$ that was used during soil loss testing.

\section{Correlations}

Correlations between the number of M1 passes and blocks and fractional aerial intercept were conducted. Fractional aerial intercept was negatively correlated with the increase in M1 passes (Table 4). No 


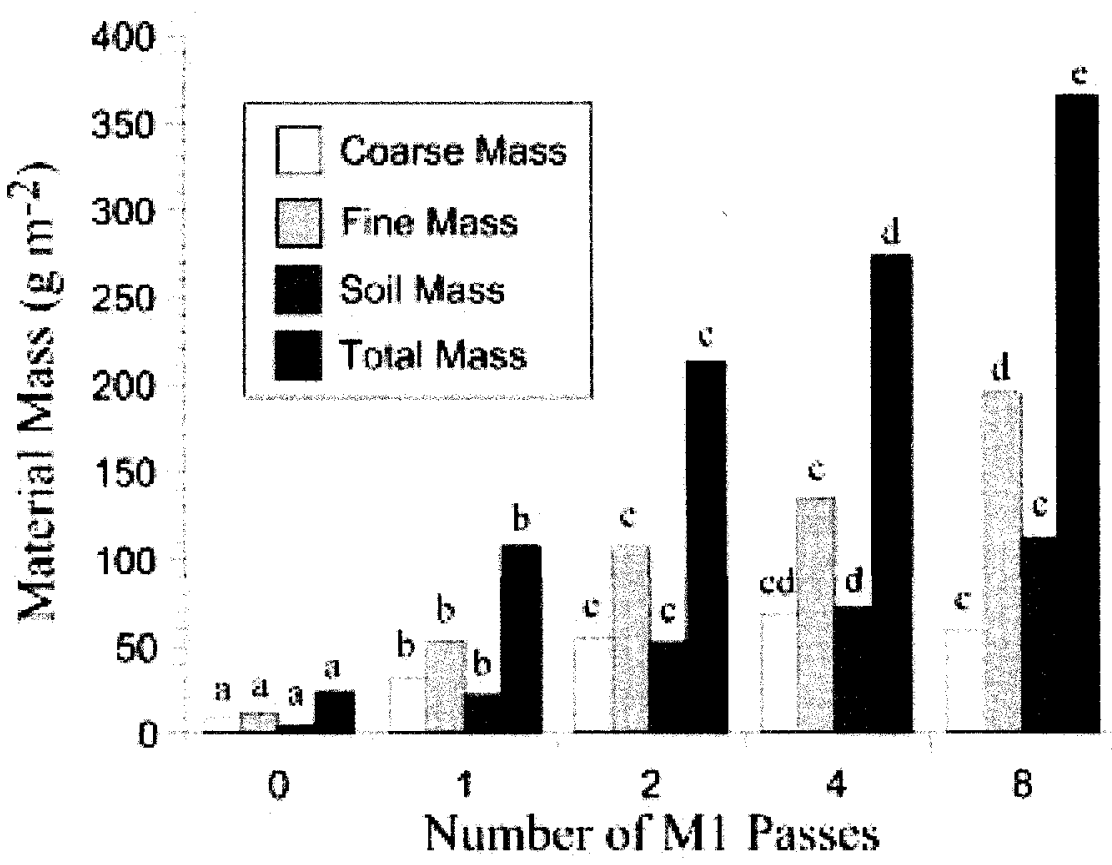

Fig. 3. Mean material mass for total mass and size class. The same letter within a weight class indicates no significant differences at $p \leq 0.05(n=145)$.

tain to level grassland areas similar to the area used for this study. These predictions are based upon the wind speed of $24 \mathrm{~m}$ $\mathrm{sec}^{-1}$ at $75 \mathrm{~mm}$ that was used during soil loss testing.

\section{Correlations}

Correlations between the number of $\mathrm{M} 1$ passes and blocks and fractional aerial intercept were conducted. Fractional aerial intercept was negatively correlated with the increase in M1 passes (Table 4). No significant correlations existed between block and fractional aerial intercept.

\section{Discussion}

\section{Effects of Tracking on Vegetation Structure and Soil Erosion}

Results indicated that particle entrainment into the air stream was not achieved for untracked areas, even at the highest wind speeds attainable by the wind tunnel. Threshold wind speed after 1 pass was significantly lower than untracked areas. This implied 2 things: 1) the untracked areas were characterized by relatively stable soil surfaces even at high wind speeds, and 2) 1 pass was sufficient to initiate significantly less stable soil surface conditions as compared with untracked areas. Work by Chepil (1956) and Gillette et al. (1980) found that material; though there was not a significant decrease in vertical vegetation struceffect of disrupting the stable soil surface. Once the surface was disrupted after 1 pass, the immediate result was the decrease in threshold wind speed and an increase in the mass of total removed parentheses indicates whether or not this correlation is significant. ture. The second crucial effect was the destruction of the vertical vegetation structure, which is evident after a comparison of the 4 tracking intensities. Vertical vegetation structure was compressed, detached, crushed into finer particles, and removed from the soil surface. As tracking intensity increased, so did the loss of vertical vegetation structure.

Past research by Marshall (1971), Gillette and Stockton (1989), Musick and Gillette (1990), and Raupach et al. (1993) concluded that vegetation structure acts as an aerodynamic roughness element with respect to the air stream. Results from this study indicated that vertical vegetation roughness elements decreased with track ing intensity after 1 pass. This decrease in the vertical vegetation roughness elements resulted in an increase in wind stress on the surface, which led to a decrease in threshold wind speed and increased rates of erosion.

The results of the predictive models also corroborated these findings. Vertical vegetation structure was shown to be the best predictor for the decrease in threshold wind speed with a strong correlation of 0.93 . Vertical vegetation structure was also the best predictor for the increase in surface material removed with an $R^{2}=$ 0.93 . It may be concluded from these models that the most significant effect of tracking on threshold wind speed and soil loss is the destruction and removal of vertical vegetation structure. However, it would not be entirely accurate to separate the effect of soil surface disruption from the destruction of vertical vegetation structure. There is probably an interactive, synergistic effect of these results on threshold wind speed and soil loss. As tracking intensity increased, the tank treads churned up the soil and began to entrench into the soil profile. Greater soil loss also resulted because of greater soil exposure.

Table 4. Top values represent Pearson Correlation Coefficients for number of passes and block designation vs. fractional aerial intercept. Numbers in Parentheses represent p-values.

\begin{tabular}{lccc} 
& $\begin{array}{c}\text { Threshold Wind } \\
\text { Speed }\end{array}$ & Soil Mass & $\begin{array}{c}\text { Fractional Aerial } \\
\text { Intercept }\end{array}$ \\
\hline M1 passes & -0.86 & 0.84 & -0.87 \\
Block -0.31 & $(0.0001)$ & $(0.0001)$ & $(0.0001)$ \\
Fractional Aerial & 0.31 & -0.21 & $(0.45)$ \\
Intercept & $(0.26)$ & $(0.54)$ & $* * *$ \\
\hline
\end{tabular}

The variables within the columns are assumed to be dependent upon the increase of the vegetation parameters. A positive top value within each cell indicates that the dependent variable increases as the independent variable increases. A negative value indicates that the dependent variable decreases as the independent variable increases. The lower number in 


\section{Comparisons of Threshold Wind Speed Results with Local Wind Speeds}

This discussion would not be complete without a comparison of the threshold wind speeds with the average wind speeds recorded for this area. Wind speeds for the years 1964-1995, 1995-1997, and 1996 are represented in Table 5 . These wind speeds were measured at 10 meters in height at Boise Municipal Airport, Boise, Ida.

Table 5. Average, maximum, and minimum wind speeds recorded at Boise Municipal Airport for years 1964-1995, 1995-1997, and 1996. Wind speeds were measured at a height of 10 meters.

\begin{tabular}{lccc}
\hline \hline & \multicolumn{3}{c}{ Wind Speed } \\
Year & Average & Maximum & Minimum \\
\hline & $\cdots \cdots-$ & $\left(\mathrm{m} \mathrm{sec}^{-1}\right)$ & $\cdots \cdots$ \\
$1964-1995$ & 3.74 & 4.52 & 3.34 \\
$1995-1997$ & 3.46 & 3.50 & 3.39 \\
1996 & 3.50 & 8.31 & 1.01 \\
\hline
\end{tabular}

The threshold wind speed necessary to initiate wind erosion for the 8-pass treatment was $12.06 \mathrm{~m} \mathrm{sec}^{-1}$. Though this wind speed is well above the average and maximum wind speeds for the recorded years, it is not unrealistic to assume gusts as high or higher than $15 \mathrm{~m} \mathrm{sec}^{-1}$ on occasion. If this is the case, then areas subjected to 4 or greater passes may experience soil erosion during these rare events. It is also necessary to keep in mind that even a small precipitation event would be enough to aggregate surface soil particles into a rain crust that would be more resistant to wind erosion than a surface without a rain crust.

\section{Conclusions and Recommendations}

The results of this study indicated that tracking by the M1A2 resulted in 2 crucial effects that contributed to increased soil erosion. Tracking has the immediate effect of disrupting the stable soil surface and the destruction of the vertical vegetation structure with increased tracking; which is evident after a comparison of the 4 tracking intensities. Removal of momentum retardant vegetation canopy with tracking intensities greater than one pass resulted in greater drag exerted on the surface of the soil which decreased threshold wind speed and removed greater amounts of soil.

Based upon these results and the likelihood of local wind speeds exceeding $15 \mathrm{~m}$ $\sec ^{-1}$, the critical tracking threshold for the M1A2 battletank at Orchard Training Area for grassland and forb dominated plant communities was concluded to be 4 passes. Tracking levels greater than or equal to four passes may result in a critical decrease in canopy cover that is necessary to protect the tracked surface from gusts of wind exceeding 15 to $17 \mathrm{~m} \mathrm{sec}^{-1}$.

Turns were not simulated in this study. Observations at the time of tracking showed that a single turn often had the result of stripping off the vertical vegetation structure, the upper 15 to 38 centimeters of the soil profile, and the creation of deep ruts. In effect, 1 turn was equivalent to greater than or equal to 8 passes in terms of vegetation and soil surface disruption. We hypothesize that 1 turn creates a highly erodible soil surface that would have threshold wind speeds similar to an area experiencing 8 or more straight passes. Further study of this aspect of tracked vehicle training exercises is necessary in order to gain a better understanding of the effects of tracked vehicle maneuvers on vegetation and soil surfaces.

Based upon these conclusions, it is recommended that special attention be paid to the management of the vertical vegetation structure. During training activities, it is suggested that activities resulting in multiple passes on the same area be minimized with the use of hardtop roads. Sharp turns that scrape off the vegetation structure and surface soil horizons should also be minimized. Any off-road use of the M1A2 should occur within the critical tracking threshold of 4 consecutive passes.

\section{Literature Cited}

Bagnold, R.A. 1941. The Physics of Blown Sand and Desert Dunes. Methuen \& Co., Ltd. London.

Bonham, C.D. 1989. Mcasurements for Terrestrial Vegetation. John Wiley \& Sons, New York.

Chepil, W.S. 1945. Dynamics of wind erosion: III. The transport capacity of the wind. Soil Sci. 60:475-480.

Chepil, W.S. 1956. Influence of moisture on soil erodibility by wind. Proc.-Soil Sci. Soc. Amer. 20:288-292.

Findlater, P.A., D.J. Carter, and W.D. Scott. 1990. A model to predict the effects of prostrate ground cover on wind erosion. Aust. J. Soil Res. 28:609-622.

Foss, C.F. ed. 1988. Jane's Armour and Artillery, 1987-1988, $8^{\text {th }}$ ed. Jane's Pub. Co. Ltd., London.

Fryrear, D.W. 1985. Soil cover and wind erosion. Trans. ASAE. 28:781-784.
Gillette, D. 1978. Tests with a portable wind tunnel for determining wind erosion threshold velocities. Atmospheric Environ. 12:2309-2313.

Gillette, D.A. 1988. Threshold friction velocities for dust production for agricultural soils. J. Geophys. Res. 93: No. D10. 12,645-12,662.

Gillette, D.A. and P.H. Stockton. 1989. The effect of non-erodible particles on wind erosion at erodible surfaces. J. Geophys. Res. $94: 12,88512,893$.

Gillette, D., J. Adams, A. Endo, D. Smith, and R. Kihl. 1980. Threshold velocities for input of soil particles into the air by desert soils. J. Geophys. Res. 85:5621-5630.

Iversen, J.D., R. Greeley, J.B. Pollack, and B.R. White. 1973. Simulation of Martian eolian phenomena in the atmospheric wind tunnel, p. 191-213. In: AIAA/NASA/ASTM/ IEMS $7^{\text {th }}$ Space Simulation Conference NASA SP-336.

Lyles, L. and R.L Schrandt. 1974. How aerodynamic roughness elements control sand movement. Trans. ASAE. 17:134-139.

Marshall, J. 1971. Drag measurements in roughness arrays of varying density and distribution. Agr. Meteorol. 8:269-292.

Marticorena, B. G., G. Bergametti, D. Gillette, and J. Belnap. 1997. Factors controlling threshold friction velocity in semiarid and arid areas of the United States. J. Geophys Res. 102(D19):23,277-23,287.

Musick, H.B. and D.A. Gillette. 1990. Ficld evaluation of relationships between a vegetation structural parameter and sheltering against wind erosion. Land Degradation and Rehab. 2:87-94.

Phillips, M. A. 1980. Force balance model for particle entrainment in a fluid stream. J. Phys. 13:221-233.

Raupach, M.R., D.A. Gillette, J.F. Leys. 1993. The effect of roughness elements on wind erosion threshold. J. of Geophys. Res. 98:No. D2: 3023-3029.

SAS. 1990. [computer program]. Version 6.11. SAS Inst. Inc. Cary, N.C

Stockton, P.H. and D.A. Gillette. 1990. Field measurement of the sheltering effect of vegetation on erodible land surfaces. Land Degradation Rehab. 2:77-85.

Williams, J.D., J.P. Dobrowolski, N.E. West, and D.A. Gillette. 1995. Microphytic crust influence on wind erosion. Trans. ASAE. 38:131-137

Wood, G.P., W. Weaver, and R. Henry. 1974. The Minimum Free-stream Wind for Initiating Motion of Surface Material on Mars. NASA Tech. Memorandum. NASA TM X-71959, NASA Langley Res. Center, Hampton, Virg. 


\title{
Long-term plant community development as influenced by revegetation techniques
}

\author{
GREGORY J. NEWMAN AND EDWARD F. REDENTE
}

Authors are research associate, Natural Resource Ecology Laboratory, Colorado State University, Fort Collins, Colo. 80523 and professor, Rangeland Ecosystem Science Department, Colorado State University, Fort Collins, Colo. 80523.

Abstract

A revegetation techniques study was initiated during the fall of 1976 in northwestern Colorado in a disturbed sagebrush (Artemisia tridentata Nutt.) community. The study included 2 irrigation treatments, three seed mixtures, 2 seeding techniques, and 2 fertilization treatments. Short-term results were published and conclusions were made regarding the initial success of each treatment. The objective of the current study was to determine the effects of each treatment on plant community production, species composition, and species diversity after 20 years of plant community development.

Among irrigated plots, the native seed mixture produced greater aboveground biomass compared to an introduced mixture and a mixture of both native and introduced species (combination seed mixture). The native seed mixture also resulted in greater total species richness than the introduced mixture when averaging over all other treatments. Altered seeding rate ratios among life forms as well as altered seeding methods (drill versus broadcast seeding) did not significantly alter plant community development after 20 years. However, a single application of nitrogen and phosphorus significantly increased grass production on plots seeded to the combination seed mixture.

All revegetation plots have remained grass-dominated. However, shrub biomass was greater in the native and combination mixtures than in the introduced mixture under initial irrigated conditions in part due to successful establishment and growth of four-wing saltbush (Atriplex canescens Pursh Nutt.). Thus, the seed mixtures evaluated in this study have resulted in distinctly different plant communities and demonstrate that such initial treatments can influence long-term plant community development on severely disturbed rangelands. Broadcast seeding a native seed mixture that has been irrigated for 2 growing seasons without fertilization appears to be an effective long-term combination of cultural revegetation practices.

Key Words: seeding, seed mixtures, fertilization, irrigation, succession, reclamation, restoration

Self-sustaining rangeland ecosystems provide ecologically important functions such as the genesis, fertility, and stability of soils; cycling of nutrients; maintenance of genetic diversity; and

The Colorado State University Agricultural Experiment Station funded the research. The authors wish to thank Russell S. Sydnor for his assistance with field sample collection.

Manuscript accepted 28 Jan. 01
Resumen

En el otoño de 1976 se inició en el noroeste de Colorado un estudio de técnicas de revegetación en una comunidad disturbada de "Sagebrush" (Artemisia tridentata Nutt.). El estudio incluyo 2 tratamientos de irrigación, 3 mezclas de semilla, 4 técnicas de siembra y 2 tratamientos de fertilización. Los resultados a corto plazo se publicaron y se realizaron conclusiones respecto al éxito inicial de cada tratamiento. El objetivo del presente estudio fue determinar los efectos de cada tratamiento en la producción de la comunidad vegetal, la composición de especies y la diversidad de especies después de 20 años de desarrollo de la comunidad. Entre las parcelas irrigadas, la mezcla de especies nativas produjo una mayor cantidad de biomasa aérea en comparación con una mezcla de semillas de especies introducidas y una mezcla de ambas especies nativas e introducidas (combinación de mezclas de semillas). Cuando se promediaron todos los tratamientos la mezcla de semillas nativas también resulto en una mayor riqueza de especies que la mezcla de semillas introducidas. Relaciones alteradas de dosis de siembra entre formas de vida así como métodos de siembra alterados (hileras contra distribución de semilla al voleo) no alteraron significativamente el desarrollo de la comunidad vegetal después de 20 años. Sin embargo, una sola aplicación de nitrógeno y fósforo incrementaron significativamente la producción de zacate en las parcelas sembradas con la combinación de mezclas de semillas. Todas las parcelas de revegetación han permanecido dominadas por zacates. Sin embargo, bajo condiciones iniciales de irrigación, la biomasa de arbustos fue mayor en la mezcla de nativas y en al combinación de mezclas que en la mezcla de introducidas, en parte debido al éxito en el establecimiento y crecimiento del "Four-wing saltbush" (Atriplex canescens Pursh Nutt.). Así, las mezclas de semillas evaluadas en este estudio han resultado en distintas comunidades vegetales y han demostrado que los tratamientos iniciales pueden influenciar el desarrollo a largo plazo de la comunidad vegetal de pastizales severamente degradados. La siembra al voleo de una mezcla de semilla nativas que ha sido irrigadas durante 2 estaciones de crecimiento y sin fertilización parece ser una combinación de prácticas culturales de revegetación efectiva a largo plazo

the preservation of natural beauty inherent in open spaces (West 1993). These ecosystems also provide economically important commodities such as forage, water, minerals, energy, building materials, and numerous recreational opportunities (National Research Council 1994). Overuse of these commodities often results in intense soil disturbances. Drastic soil disturbances that degrade rangeland ecosystems impair inherent ecological func- 
tions because they remove excessive amounts of vegetation, destabilize ground surfaces, and alter ecosystem structure.

Successful reclamation of intensely disturbed soil is needed because: (1) it can help restore ecosystem structure and function by accelerating the establishment of diverse, self-sustaining plant communities, (2) without it, disturbed areas can remain depauperate of vegetation for many years (Knabe 1965), (3) it can help stabilize erosion-prone sites and reestablish lost commodities and services, and (4) certain federal and state reclamation laws require that plant diversity, canopy cover, and production on reclaimed sites be equal to or greater than the surrounding natural vegetation (Surface Mining Control and Reclamation Act 1977).

Restoration ecologists are typically concerned with meeting certain operationally defined reclamation "success criteria" within short time scales. Such short-term emphasis has arisen from (1) the time scale associated with bond release requirements in various state and federal laws and (2) the difficulties associated with initially establishing vegetation on severely disturbed sites. Consequently, restoration ecologists often utilize cultural practices to aid plant community establishment and development. However, funding is often limited for long-term monitoring, evoking the question: can initial short-term treatments have predictable long-term consequences? If initial revegetation techniques can, in a predictable fashion, direct the long-term outcome of plant community development on disturbed sites, restoration ecologists may be able to adopt a more long-term perspective aimed at achieving specific restoration goals.

The goals for successful rangeland reclamation, although widely debated because of different land use objectives, generally focus on short-term site stabilization and long-term ecosystem sustainability. DePuit (1988) stated that successful rangeland reclamation should provide adequate soil stabilization, support for desired land uses, ecological stability, and self-maintenance. For mining related disturbances, Redente and DePuit (1988) stated that reclamation should aim to: (1) provide immediate control of wind and water erosion by stabilizing the disturbed site with vegetation and (2) "...establish a diverse, effective, and self-sustaining plant community."

Reclamation is generally successful at meeting initial vegetation cover and production goals on various soil disturbances. However, the long-term efficacy of vari- ous revegetation practices has not been adequately documented. Additionally, although various revegetation practices have been shown to yield productive plant communities on some sites, species diversity (richness) goals have proven difficult to achieve (Chambers et al. 1994, DePuit 1984, Hatton and West 1987, Redente et al. 1984, Sindelar 1980, Stark and Redente 1985). Thus, documenting the long-term effects revegetation practices have on developing plant communities when used on drastically disturbed rangelands is essential to meet reclamation goals.

In this paper we evaluate the long-term effects of various revegetation techniques on a disturbed site in northwestern Colorado. The specific objective of this study was to determine the long-term effects of initial irrigation treatments, seed mixtures, seeding techniques, and fertilizer applications on net primary production, species composition, and species richness.

\section{Materials and Methods}

A detailed account of the study site location and original study methods can be found in Doerr et al. (1983). The study was initiated during the fall of 1976 in the Piceance Basin about $65 \mathrm{~km}$ northwest of Rifle, Colo. (39 $\left.54^{\prime} 14^{\prime \prime} \mathrm{N}, 108^{\circ} 24^{\prime} 03^{\prime \prime} \mathrm{W}\right)$ at an elevation of $2,200 \mathrm{~m}$. The study area was classified within the Mid-Elevation Big Sagebrush/Moderately Deep Loams Phyto-edaphic Unit as described by Teidman and Terwilliger (1978). Big sagebrush (Artemisia tridentata Nutt.) is the dominant species in undisturbed plant communities. Common under story species include: western wheatgrass (Agropyron smithii Rydb.), prairie junegrass (Koeleria macrantha (Ledeb.) J.A.), Indian ricegrass (Oryzopsis hymenoides (R. \& S.) Ricker), Needle-and-thread grass (Stipa comata Trin. \& Rupr.), carpet phlox (Phlox hoodii Richards), and scarlet globemallow (Sphaeralcea coccinea (Pursh.) Rydb.). Detailed soil characteristics prior to disturbance can be found in Doerr et al. (1983). Soils on the site were fine loamy, mixed, Borillic Camborthids. Mean annual precipitation (MAP) on the site is $282 \mathrm{~mm}$, with half of this precipitation received as snow.

\section{Experimental Design}

To create an intensive soil disturbance, six $(16 \times 92.5 \mathrm{~m})$ blocks of land were scraper excavated to a depth of $1 \mathrm{~m}$ in the fall of 1976. The excavated material (including both topsoil and rockier subsoil) was then mixed and returned to each site, creating a rocky growth medium with levels of nitrogen $(\mathrm{N})$ and phosphorus $(\mathrm{P})$ that were approximately half that of predisturbance levels (Doerr et al. 1983). The experimental design of the study consisted of a completely randomized, split-splitsplit plot, factorial experiment with 3 replications (Fig. 1). The treatments applied in 1976 included irrigation, seed mixtures, seeding techniques, and fertilization.

Irrigation treatments included either the addition of supplemental water on a weekly basis throughout the growing season (beginning in early June) for 2 years (1977 and 1978) or no irrigation. The amount of water added to irrigated plots brought the total water received (precipitation + irrigation) to $2.5 \mathrm{~cm}^{\text {week }}{ }^{-1}$. Supplemental water was applied with a sprinkler irriga-

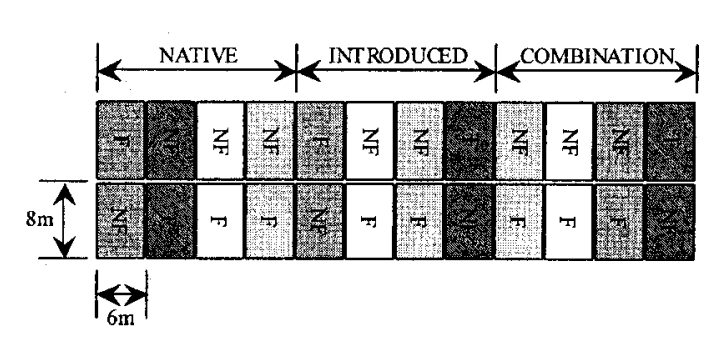

\section{LEGEND}

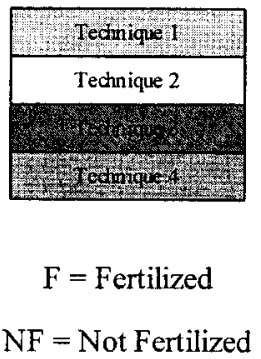

Fig. 1. One of 3 replicate blocks per each irrigation treatment illustrating the split-split-split randomized complete block experimental design used in the study. Three of these blocks were irrigated for the first 2 growing seasons of the study and 3 were not irrigated. The distribution of the seed mixtures (each mixture being applied to an area of 8 plots), the 4 seeding techniques (each technique being applied to east-west strips consisting of 2 plots), and the fertilization treatment (applied to individual plots) were completely randomized and differed for each irrigated or not irrigated replicate block. 
Table 1. The speciès seeded for each of the 3 seed mixtures used in the Revegetation Techniques Study. The seeding rate for each species as well as the total rate for each seeding technique are listed as pure live seed (PLS) in $\mathrm{kg} \mathrm{ha}^{-1}$.

\begin{tabular}{|c|c|c|c|c|c|}
\hline \multirow[b]{2}{*}{ Common Name } & \multirow[b]{2}{*}{ Scientific Name } & \multicolumn{4}{|c|}{ Seeding Rate PLS } \\
\hline & & Tech 1 & Tech 2 & Tech 3 & $\operatorname{Tech} 4$ \\
\hline & & $\cdots$ & $\cdots$ & $\cdots \cdots$ & $\cdots \cdots$ \\
\hline \multicolumn{6}{|c|}{ Combination Seed Mixture } \\
\hline Nordan crested wheatgrass & Agropyron desertorum & 1.12 & 0.56 & 1.12 & 1.12 \\
\hline Siberian wheatgrass & Agropyron sibericum & 1.12 & 0.56 & 1.12 & 2.24 \\
\hline Critana thickspike wheatgrass & Agropyron dasystachyum & 1.12 & 0.56 & 2.24 & 3.36 \\
\hline Sodar streambank wheatgrass & Agropyron riparium & 1.12 & 0.56 & 2.24 & 3.36 \\
\hline Slender wheatgrass & Agropyron trachycaulum & 1.12 & 0.56 & 2.24 & 3.36 \\
\hline Regar meadow brome & Bromus biebersteinii & 1.12 & 0.56 & 1.12 & 2.24 \\
\hline Indian ricegrass & Oryzopsis hymenoides & 1.12 & 0.56 & 2.24 & 2.24 \\
\hline Green needlegrass & Stipa viridula & 1.12 & 0.56 & 2.24 & 3.36 \\
\hline Durar hard fescue & Festuca ovina duriscula & 0.56 & 0.28 & 0.56 & 1.12 \\
\hline Madrid yellow sweetclover & Melilotus officinalis & 0.56 & 0.28 & 0.56 & 0.56 \\
\hline Sweetvetch & Hedysarum boreale & 1.12 & 0.56 & 1.12 & 1.68 \\
\hline Globemallow & Sphaeralcea munroana & 0.56 & 0.56 & 0.56 & 1.12 \\
\hline Lewis flax & Linum lewisii & 0.56 & 0.56 & 0.56 & 1.12 \\
\hline Arrowleaf balsamroot & Balsamorhiza sagittata & 1.12 & 0.56 & 1.12 & 1.68 \\
\hline Fourwing saltbush & Atriplex canescens & 1.12 & 4.48 & 0.00 & 0.00 \\
\hline Stansbury cliffrose & Cowania mexicana stansburiana & 1.12 & 3.36 & 0.00 & 0.00 \\
\hline Winterfat & Ceratoides lanata & 1.12 & 2.24 & 0.00 & 0.00 \\
\hline \multirow[t]{2}{*}{ Green ephedra } & Ephedra viridis & 1.12 & 2.24 & 0.00 & 0.00 \\
\hline & Total & 17.92 & 19.60 & 19.04 & 28.56 \\
\hline \multicolumn{6}{|c|}{ Native Seed Mixture } \\
\hline Rosana western wheatgrass & Agropyron smithii & 1.12 & 0.56 & 3.36 & 4.48 \\
\hline Sodar streambank wheatgrass & Agropyron riparium & 1.12 & 0.56 & 1.12 & 2.24 \\
\hline Bearded bluebunch wheatgrass & Agropyron spicatum & 1.12 & 0.56 & 2.24 & 4.48 \\
\hline Indian ricegrass & Oryzopsis hymenoides & 1.12 & 0.56 & 2.24 & 4.48 \\
\hline Green needlegrass & Stipa viridula & 1.12 & 0.56 & 2.24 & 4.48 \\
\hline Shermans big bluegrass & Poa secunda & 1.12 & 0.56 & 1.12 & 1.12 \\
\hline Alkali sacaton & Sporobolus airoides & 0.56 & 0.28 & 0.56 & 1.12 \\
\hline Globemallow & Sphaeralcea munroana & 0.56 & 0.28 & 0.56 & 1.12 \\
\hline Sweetvetch & Hedysarum boreale & 1.12 & 0.56 & 1.12 & 1.12 \\
\hline Palmer penstemon & Penstemon palmeri & 0.56 & 0.28 & 0.56 & 1.12 \\
\hline Stansbury cliffrose & Cowania mexicana stansburiana & 2.24 & 4.48 & 0.00 & 0.00 \\
\hline Green ephedra & Ephedra viridis & 1.12 & 3.36 & 0.00 & 0.00 \\
\hline Fourwing saltbush & Atriplex canescens & 1.12 & 3.36 & 0.00 & 0.00 \\
\hline Winterfat & Ceratoides lanata & 1.12 & 2.24 & 0.00 & 0.00 \\
\hline \multirow[t]{2}{*}{ Antelope bitterbrush } & Purshia tridentata & 1.12 & 3.36 & 0.00 & 0.00 \\
\hline & Total & 16.80 & 21.84 & 15.68 & 26.88 \\
\hline \multicolumn{6}{|c|}{ Introduced Seed Mixture } \\
\hline Nordan crested wheatgrass & Agropyron desertorum & 1.12 & 0.56 & 2.24 & 3.36 \\
\hline Siberian wheatgrass & Agropyron sibericum & 1.12 & 0.56 & 1.12 & 2.24 \\
\hline Jose tall wheatgrass & Agropyron elongatum & 1.12 & 0.56 & 2.24 & 3.36 \\
\hline Luna pubescent wheatgrass & Agropyron trichophorum & 1.12 & 0.56 & 1.12 & 2.24 \\
\hline Oahe intermediate wheatgrass & Agropyron intermedium & 1.12 & 0.56 & 1.12 & 2.24 \\
\hline Manchar smooth brome & Bromus inermis & 1.12 & 0.56 & 1.12 & 2.24 \\
\hline Regar meadow brome & Bromus biebersteinii & 1.12 & 0.56 & 2.24 & 4.48 \\
\hline Vinal Russian wildrye & Elymus junceus & 1.12 & 0.56 & 1.12 & 2.24 \\
\hline Ladak alfalfa & Medicaga sativa & 0.56 & 0.28 & 0.56 & 1.12 \\
\hline Madrid yellow sweetelover & Melilotus officinalis & 0.56 & 0.28 & 0.56 & 1.12 \\
\hline Lutana cicer milkvetch & Astragalus cicer & 0.56 & 0.56 & 0.56 & 1.12 \\
\hline Sainfoin & Onobrychis viciaefolia & 0.56 & 0.56 & 0.56 & 1.12 \\
\hline Bouncing bet & Saponaria officinalis & 1.12 & 1.12 & 1.12 & 2.24 \\
\hline Small burnet & Sanguisorba minor & 1.12 & 1.12 & 1.12 & 2.24 \\
\hline Siberian peashrub & Caragana arborescens & 1.12 & 4.48 & 0.00 & 0.00 \\
\hline \multirow[t]{2}{*}{ Russian olive } & Elaeagnus angustifolia & 2.24 & 4.48 & 0.00 & 0.00 \\
\hline & Total & 16.80 & 17.36 & 16.80 & 31.36 \\
\hline
\end{tabular}

tion system using impact heads. Three seed mixtures used included: (1) a combination mixture of 13 native and 5 introduced species, (2) a native mixture of 15 native species, and (3) an introduced mixture of 16 introduced species (Table 1). The 4 seeding techniques evaluated (T1-
T4) consisted of seeding the specified life forms for each seed mixture with the following methods and rates: (T1) grass, forb, and shrub species drill seeded (power-till seeder with packer wheels) at a rate of $17 \mathrm{~kg} \mathrm{ha}^{-1}$; (T2) grass, forb, and shrub species drill seeded at a rate of 19 $\mathrm{kg} \mathrm{ha}^{-1}$ (with a shrub seeding rate approximately 2 times greater than in T1 and a grass and forb seeding rate approximately one-half that of $\mathrm{T} 1$ ); (T3) grass and forb species drill seeded at a rate of $17 \mathrm{~kg} \mathrm{ha}^{-1}$; and (T4) grass and forb species broadcast seeded at a rate of $29 \mathrm{~kg} \mathrm{ha}^{-1}$ and hand- 
Table 2. ANOVA table illustrating main effects and their interactions for the response varaiable of $\log ($ total biomass).

\begin{tabular}{llcc}
\hline \hline Treatment Interaction(s) & DF & F Statistic & p Value \\
\hline Trrigation & 4 & 0.57 & 0.4918 \\
Mixture & 92 & 11.17 & 0.0001 \\
Irrigation*Mixture & 92 & 10.11 & 0.0001 \\
Technique & 92 & 0.74 & 0.5331 \\
Irrigation*Technique & 92 & 1.70 & 0.1716 \\
Mixture*Technique & 92 & 1.12 & 0.3553 \\
Irrigation*Mixture*Technique & 92 & 1.29 & 0.2712 \\
Fertilization & 92 & 1.69 & 0.1969 \\
Irrigation*Fertilization & 92 & 0.02 & 0.8874 \\
Mixture*Fertilization & 92 & 2.43 & 0.0938 \\
Irrigation*Mixture*Fertilization & 92 & 0.49 & 0.6134 \\
Technique*fertilization & 92 & 0.38 & 0.7694 \\
Irrigation*Technique*Fertilization & 92 & 1.00 & 0.3963 \\
Mixture*Technique*Fertilization & 92 & 0.50 & 0.8061 \\
Irrigation*Mixture*Technique*Fertilization & 92 & 0.72 & 0.6376 \\
\hline
\end{tabular}

raked to cover with soil (Table 1 ). The 2 fertilization treatments included: (1) the application of $112 \mathrm{~kg} \mathrm{~N} \mathrm{ha}^{-1}$ and $90 \mathrm{~kg} \mathrm{P}$ $\mathrm{ha}^{-1}$ and (2) no fertilizer. All treatments were allocated among a total of $144(8 \times 6$ $\mathrm{m})$ experimental plots. After seeding, the entire study was hydro-mulched with wood fiber at a rate of $2.2 \mathrm{MT}^{-1} \mathrm{a}^{-1}$.

\section{Sampling Methodology}

We assessed plant community development in each plot by clipping current year aboveground biomass by species inside each of 5 randomly located $0.5 \times 1.0 \mathrm{~m}$ $\left(0.5 \mathrm{~m}^{2}\right)$ quadrats in June of 1997 . Individuals of each species in all five quadrats were harvested together, ovendried at $50^{\circ} \mathrm{C}$ for 48 hours, and weighed. We obtained plant species richness (i.e. the mean number of species encountered per plot) from the total number of species encountered in each of the 5 quadrats sampled per plot.

To compare the plant communities present on the experimental plots to a reference area that had not been severely modified by excavation but had been exposed to cattle and wildlife grazing for numerous years prior to our study, we used data sampled in an adjacent reference area during the years of 1987, 1989, 1991, and 1992. Four replicate reference plots, each $500 \mathrm{~m}^{2}$ in area, were sampled with 10 randomly placed $0.5 \mathrm{~m}^{2}$ quadrats.

\section{Data Analysis}

Differences between, and interactions among, treatments were analyzed using four-way analysis of variance (ANOVA) techniques for a split-split-split plot experimental design. The analyses were run by life form as well as total production for each treatment using the MIXED proce(loss of precision), while comparisons between seed mixtures (factor B) within a given level of irrigation (factor A) were more sensitive (Kuehl 1994). This tendency generally occurs because of pooled error variances and differing degrees of freedom in split-plot experimental designs (Steel and Torrie 1980).

\section{Results and Discussion}

\section{Irrigation and Seed Mixtures Biomass production}

Initially, in 1978, total biomass of both the combination and introduced seed mixtures was greater than the native mixture on irrigated plots (Doerr et al. 1983). Conversely, on non-irrigated plots, total biomass in the native seed mixture was greater than in both the combination and introduced mixtures. However, by 1979 , total biomass was roughly equal between all 3 seed mixtures on both irrigated and non-irrigated plots.

Irrigation also increased grass and forb biomass in 1978 and 1979 , especially in the introduced seed mixture. This increase corresponded with a decrease in shrub biomass (Doerr et al. 1983). These short-term results are consistent with those of May et al. (1971) and DePuit et al. (1982). Thus, irrigation for 2 growing seasons in a sagebrush steppe ecosystem may initially promote rapid grass production and aid in short-term erosion control. However, the long-term consequences of short-term irrigation appear to be different.

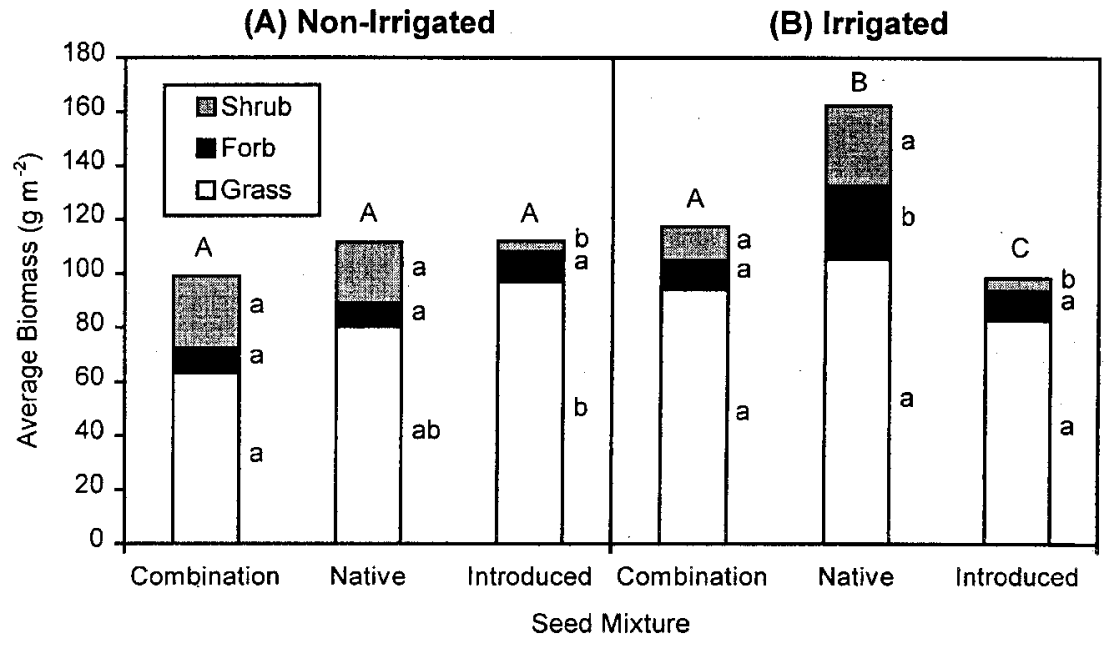

Fig. 2. (A) Mean total aboveground biomass of each seed mixture by life form among nonirrigated plots. (B) Mean total aboveground biomass of each seed mixture by life form among irrigated plots. Mean total biomass values with different upper-case letters within each irrigation treatment among seed mixtures are significantly different $(p<0.05)$. Mean grass, forb, and shrub biomass values within each irrigation treatment among seed mixtures with different lower-case letters are significantly different $(p<0.05)$. 
By 1997 , the native seed mixture produced greater total biomass than both the combination and introduced mixtures on irrigated plots (Fig. 2-B). Additionally, the combination seed mixture also produced greater total biomass than the introduced mixture when irrigated. However, on nonirrigated plots, there were no differences in total biomass among the 3 seed mixtures (Fig. 2-A). Thus, the 3 seed mixtures studied were found to be equally productive under non-irrigated conditions, but the native seed mixture out-produced both the combination and introduced seed mixture (after 20 years) when irrigated for 2 growing seasons. This interaction between irrigation and seed mixture was largely caused by increased native forb and shrub biomass under irrigated conditions.

Mean forb biomass was greater in the native seed mixture than the combination and introduced seed mixtures when irrigated (Fig. 2-B). Forb biomass in the native mixture was almost 3 times as great as that in either the combination or introduced mixture (Fig. 2-B). However, no differences in forb biomass were observed among the 3 seed mixtures when irrigation was not applied (Fig. 2-A). Mean shrub biomass in both the combination and native seed mixtures was significantly greater than in the introduced seed mixture under irrigated conditions (Fig. 2-B). Similarly, shrub biomass in both the combination and native seed mixture was also greater than in the introduced mixture when not irrigated (Fig. 2-A).

\section{Species composition}

The influence of irrigation on species composition was still evident after 20 years. The dominant species on all irrigated plots was hard fescue (Festuca ovina var. duriscula A. Gray ex. Port. and Coult.). Fescue biomass averaged $24 \mathrm{~g}$ $\mathrm{m}^{-2}$, which represented $19 \%$ of the total biomass produced on irrigated plots. However, on all non-irrigated plots, hard fescue was a minor species, producing only $3 \mathrm{~g} \mathrm{~m}^{-2}$ and representing only $3 \%$ of the total biomass. The dominant species on non-irrigated plots was crested wheatgrass (Agropyron desertorum (Fisch.) Schult.), which contributed $17 \%$ of the total biomass compared to $14 \%$ of the total biomass on irrigated plots (where it was the second most dominant species).

The lack of long-term studies evaluating species composition after irrigation makes it difficult to address the hypothesis that irrigation favors the establishment and subsequent persistence of certain species. There are many studies that report on the short-term effects of irrigation during reclamation, but these studies provide little insight into long-term consequences of irrigation. For example, DePuit et al. (1982) evaluated individual species response to irrigation in southeastern Montana and concluded that western wheatgrass, slender wheatgrass (Agropyron trachycaulum (Link) Malte ex H.F. Lewis), smooth bromegrass (Bromus inermis Leyss.), and yellow sweetclover (Melilotus officinale) were species that showed a positive response to irrigation after 2 growing seasons. Results of our study are contrary to those of DePuit et al. (1982) for all species except smooth bromegrass. Smooth bromegrass showed an increase in production with irrigation, but the remaining species showed either a decline in production (western wheatgrass) or no effect after 20 years. Further research is needed to address the hypothesis that irrigation favors the establishment and long-term persistence of certain species because of differences in environmental conditions and competitive interactions among species.

Regardless of the mechanisms underlying potential long-term community level and species specific irrigation effects, restoration ecologists need to weigh: (1) the costs of initial irrigation, (2) the practical importance of possible long-term irri- gation effects, and (3) the necessity for rapid site stabilization that may be achieved with irrigation (Doerr et al. 1983, Farmer et al. 1974, Ries and Day 1978) before a final decision is made.

The seed mixtures used in this study also influenced species composition of the established communities after 20 years (Table 3). The plant communities present on plots seeded to each of the 3 seed mixtures have remained dominated by species that were originally seeded in 1976, indicating that the species originally seeded have inhibited colonization by neighboring species. For example, of the 18 species initially seeded in the combination seed mixture, 13 species $(72 \%)$ were still present after 20 years. These 13 species represented $67 \%$ of the total biomass reported for the combination mixture. Similarly, 11 species of the 15 originally seeded ( $73 \%$ ) were still present in the native seed mixture; representing $76 \%$ of the total biomass of the native mixture. Conversely, only 7 species of the 16 seeded $(44 \%)$ in the introduced mixture were still present after 20 years. However, these 7 species represented $94 \%$ of the total biomass of the introduced mixture.

These results are consistent with those of Redente et al. (1997) on a top soiled coal mine in northwestern Colorado. In this study, the 6 most productive species

Table 3. Mean percent species composition of each seed mixture compared to the mean percent species composition of the native reference area. Major species shown comprise $\geq 5 \%$ of the mean total biomass on any of the 3 seed mixtures and/or the undisturbed reference area plant community. All other species (not shown) comprise $<5 \%$ of the mean total biomass on each of the 3 seed mixtures and $<5 \%$ on the undisturbed plant community. These minor species (not shown) are labeled as 'Other'. Standard error's (s.e.) are also given for each percentage value.

\begin{tabular}{|c|c|c|c|c|c|c|c|c|}
\hline \multirow{2}{*}{$\begin{array}{l}\text { Species } \\
\text { Code }^{1}\end{array}$} & \multicolumn{2}{|c|}{ Combination } & \multicolumn{2}{|c|}{ Native } & \multicolumn{2}{|c|}{ Introduced } & \multicolumn{2}{|c|}{ Undisturbed } \\
\hline & $(\%)$ & (s.e.) & $(\%)$ & (s.e.) & $(\%)$ & (s.e.) & $(\%)$ & (s.e.) \\
\hline Agrdes & 30 & 3.07 & 2 & 0.88 & 18 & 2.12 & $\mathrm{~T}^{2}$ & $\mathrm{~T}$ \\
\hline Agrint & $\mathrm{T}$ & $\mathrm{T}$ & 1 & 0.37 & 40 & 4.45 & $\mathrm{~T}$ & $\mathrm{~T}$ \\
\hline Agrsmi & 9 & 1.29 & 7 & 1.04 & $\mathrm{~T}$ & $\mathrm{~T}$ & 2 & 0.02 \\
\hline Agrspi & $\mathrm{T}$ & $\mathrm{T}$ & 32 & 4.31 & $\mathrm{NP}^{3}$ & NP & $\mathrm{T}$ & $\mathrm{T}$ \\
\hline Broine & 8 & 1.32 & 1 & 0.49 & 6 & 1.15 & $\mathrm{NP}$ & NP \\
\hline Elyjun & $\mathrm{T}$ & $\mathrm{T}$ & $\mathrm{T}$ & $\mathrm{T}$ & 21 & 2.53 & $\mathrm{NP}$ & NP \\
\hline Fesovi & 20 & 4.54 & 13 & 3.70 & $\mathrm{~T}$ & $\mathbf{T}$ & $\mathrm{NP}$ & NP \\
\hline Koemac & NP & NP & $\mathrm{T}$ & $\mathrm{T}$ & $\mathrm{T}$ & $\mathbf{T}$ & 6 & 0.06 \\
\hline Poasec & $\mathrm{T}$ & $\mathrm{T}$ & 6 & 2.53 & $\mathrm{~T}$ & $\mathrm{~T}$ & 2 & 0.02 \\
\hline Hedbor & 6 & 1.20 & 10 & 2.99 & $\mathrm{~T}$ & $\mathrm{~T}$ & $\mathrm{~T}$ & $\mathrm{~T}$ \\
\hline Medsat & $\mathrm{T}$ & $\mathrm{T}$ & 1 & 0.95 & 7 & 1.42 & NP & NP \\
\hline Arttri & 3 & 1.49 & 2 & 1.36 & 3 & 1.59 & 63 & 0.63 \\
\hline Atrcan & 7 & 1.93 & 7 & 2.29 & $\mathrm{~T}$ & $\mathrm{~T}$ & $\mathrm{NP}$ & $\mathrm{NP}$ \\
\hline Ephvir & 2 & 0.68 & 6 & 3.47 & NP & NP & NP & NP \\
\hline Other & 15 & & 12 & & 5 & & 27 & \\
\hline Total & 100 & & 100 & & 100 & & 100 & \\
\hline
\end{tabular}

'Species codes are as follows: 'Agrdes' $=$ Agropyron deserortum, 'Agrint' $=A$. intermedium. 'Agrsmi' $=A$. smithii, 'Agrspi' = A. Spicatum, 'Broine' = Bromus inermis, 'Elyjun' = Elymus junceus, 'Fesovi' = Festuca ovina var. duriscula, 'Koemac' = Koeleria macrantha, 'Poasec' = Poa secunda, 'Hedbor' = Hedysarum boreale, 'Medsat' = Medicago sativa, 'Arttri' = Artemisia tridentata, 'Atrcan' = Atriplex canescens, and 'Ephvir' = Ephedra viridis.

${ }^{2} \mathrm{~T}=$ Trace amount present.

${ }^{3} \mathrm{NP}=$ Not present. 
(smooth bromegrass; basin wildrye (Elymus cinereus); cicer milkvetch (Astragalus cicer L.); western wheatgrass; intermediate wheatgrass (Agropyron intermedium (Host) Beauv.); and crested wheatgrass) together accounted for $90 \%$ of the total biomass of all top soiled treatments after 10 years.

Distinctly different plant communities resulted from the use of seed mixtures with all native or all introduced species. A more shrub-based plant community, as well as a diverse mixture of other species, developed on plots seeded with the native seed mixture. Conversely, because of poor establishment of seeded introduced shrub species (Doerr et al. 1983), a predominately grass community dominated by crested wheatgrass, intermediate wheatgrass, Russian wildrye (Elymus junceus (Fisch.) Nevski.), and smooth bromegrass developed on plots seeded to the introduced seed mixture. The biomass of these 4 grass species represented $85 \%$ of the total biomass reported for plots seeded to the introduced seed mixture.

These results are similar to those of Walker et al. (1995) on chained pinyonjuniper sites in Utah. In their study, crested wheatgrass was seeded on chained sites and was found to be increasing in terms of density and productivity after 20 years. Similar long-term species composition differences were reported by Sydnor (1999) on revegetation plots in Colorado that used seed mixtures similar to those used in this study. Perhaps seeded sites in sagebrush ecosystems reach a state that, analogous to recent state-transition (ST) models (Allen-Diaz and Bartolome 1998), requires substantial energy input to move the established community to a new community type.

\section{Species richness}

Finally, irrigation had no long-term effect on species richness after 20 years of plant community development. Species richness was not different between irrigated plots and non-irrigated plots when averaging over all treatments. There were no significant interactions for species richness between any other treatments.

The seed mixtures used in this study produced differences in species richness after 20 years. This main effect was not dependent upon any other treatment. Plots seeded to the introduced seed mixture had the lowest species richness after 20 years. The mean total number of species present on plots seeded to the combination mixture (10 species per plot) and native mixture (12 species per plot) was greater than on plots seeded to the introduced mixture (7 species per plot). Consequently, bond release requirements or long-term land use objectives may not be met (or maintained over longer time scales) when using solely introduced species. These results may be related to the different competitive abilities of the grasses seeded in both these seed mixtures. A study by Eissenstat and Caldwell (1988) showed that the competitive abilities of crested wheatgrass and bluebunch wheatgrass are markedly different due to differences in the ability of each species' root system to extract soil water.

\section{Seeding Techniques and Fertilization}

Short-term studies have shown that broadcast seeding is as effective as drill seeding when broadcast seeding rates are twice that of drill seeding (Doerr and Redente 1983, DePuit and Coenenberg 1979). This is contrary to the conventional short-term wisdom that drill seeding should perform better than broadcast seeding because drilling places seed at an optimum depth and in good contact with the soil environment. However, our 1997 results support the hypothesis that broadcast seeding can be equally effective as drill seeding in the long-term.
Of the 4 seeding techniques included, only comparisons among (a) the effects of the 2 seeding rate ratios ( $\mathrm{T} 1$ and $\mathrm{T} 2$ ) and (b) the effects of the 2 seeding methods (T3 and T4; drill and broadcast seeding of grass and forb species, respectively) were of specific a priori ecological interest. No differences existed between $\mathrm{T} 1$ and $\mathrm{T} 2$ for total biomass or biomass of individual life forms after 20 years. Similarly, no differences existed for total and life form biomass between T3 and T4. Species composition differed only slightly between $\mathrm{T} 1$ and $\mathrm{T} 2$ and $\mathrm{T} 3$ and $\mathrm{T} 4$ (Table 4). Species richness did not differ between $\mathrm{T} 1$ plots and $\mathrm{T} 2$ plots, nor did it differ between drill-seeded plots (T3) and broadcast seeded plots (T4). Thus, no differences were found between drill seeding (T3) and broadcast seeding (T4) for production among life forms, total production, and species richness.

However, some differences existed between fertilized and non-fertilized plots. Grass biomass was greater on plots seeded to the combination seed mixture on fertilized plots than on non-fertilized plots. Certain species appeared to have been influenced by the initial fertilization application. Hard fescue represented $16 \%$ of

Table 4. Percent species composition on seeding techniques $1,2,3$, and 4 . Seeding technique 1 consisted of drill seeding grass, forb, and shrub species in each seed mixture at a rate of $17 \mathrm{~kg} \mathrm{ha}^{-1}$. Conversely, seeding technique 2 consisted of drill seeding grass, forb, and shrub species at $17 \mathrm{~kg}$ $\mathrm{ha}^{-1}$, but with an increased shrub seeding rate and a decreased grass and forb seeding rate relative to technique 1 . Seeding technique 3 involved drill seeding grass and forb species in each seed mixture at a rate of $17 \mathrm{~kg} \mathrm{ha}^{-1}$. Seeding technique 4 involved broadcast seeding grass and forb species in each seed mixture at a rate of $29 \mathrm{~kg} \mathrm{ha}^{-1}$ and lightly covering the seed with soil. Species shown produced $\geq 5 \%$ of the total biomass on either seeding techniques 1 or 2 or on techniques 3 or 4. Species that comprise $<5 \%$ of the total biomass on seeding techniques 1 and 2 or 3 and 4 are labeled as 'Other species'. Standard error's (s.e.) are also shown.

\begin{tabular}{|c|c|c|c|c|}
\hline \multirow[b]{2}{*}{ Species } & \multicolumn{2}{|c|}{ Tech. 1 (>grass/forb) } & \multicolumn{2}{|c|}{ Tech. 2 (>shrub) } \\
\hline & $(\%)$ & (s.e.) & $(\%)$ & (s.e.) \\
\hline Agropyron desertorum & 18 & 3.1 & 17 & 2.4 \\
\hline Agropyron intermedium & 11 & 2.9 & 15 & 3.9 \\
\hline Agropyron smithii & 6 & 1.2 & 8 & 1.8 \\
\hline Agropyron spicatum & 10 & 3.1 & 6 & 2.8 \\
\hline Atriplex canescens & 6 & 1.5 & 10 & 1.9 \\
\hline Elymus junceus & 9 & 2.6 & 6 & 1.8 \\
\hline Ephedra viridis & 2 & 0.9 & 6 & 2.1 \\
\hline Festuca ovina var. duriscula & 11 & 3.1 & 6 & 2.2 \\
\hline Poa secunda & 5 & 2.0 & 3 & 1.1 \\
\hline Other species & 22 & & 23 & \\
\hline \multirow[t]{2}{*}{ Total composition } & 100 & & 100 & \\
\hline & \multicolumn{2}{|c|}{ Tech. 3 (drill) } & \multicolumn{2}{|c|}{ Tech. 4 (broadcast) } \\
\hline Species & $(\%)$ & (s.e.) & $(\%)$ & (s.e.) \\
\hline Agropyron desertorum & 15 & 2.9 & 18 & 3.2 \\
\hline Agropyron intermedium & 17 & 4.0 & 12 & 3.5 \\
\hline Agropyron smithii & 7 & 2.2 & 7 & 2.2 \\
\hline Agropyron spicatum & 16 & 4.1 & 14 & 3.7 \\
\hline Elymus junceus & 7 & 2.3 & 8 & 2.8 \\
\hline Festuca ovina var. duriscula & 11 & 3.1 & 13 & 3.5 \\
\hline Hedysarum boreale & 6 & 1.5 & 8 & 2.0 \\
\hline Other species & 21 & & 20 & \\
\hline Total composition & 100 & & 100 & \\
\hline
\end{tabular}


the total biomass produced on fertilized plots. On non-fertilized plots, fescue biomass represented only $7 \%$ of the total biomass. Otherwise, species composition on fertilized plots closely approximated species composition on non-fertilized plots.

Fertilization can lead to a more productive growth medium. Under non-equilibrium conditions (typical of disturbed sites), Huston (1979) hypothesized that conditions that increase the production potential of competitive species theoretically result in lower species richness because of increased competitive exclusion. Studies by Biondini and Redente (1986), Stark and Redente (1985), and Redente et al. (1997) in northwestern Colorado supported this hypothesis. However, results from this study (evaluating effects of a one-time application of $\mathrm{N}$ and $\mathrm{P}$ ) showed no significant decline in species richness on fertilized plots compared to non-fertilized plots.

This discrepancy may be related to differences in the length of time that these higher productivity conditions persist. For example, the stimuli evaluated by Stark and Redente (1985) were associated with soil characteristics (i.e. percent coarse fragments, depth to bedrock, topography, salt content, and soil fertility) that should have long-term influences on site productivity. Conversely, the initial one-time fertilization application evaluated in the current study may not have increased site productivity long enough to substantially increase the growth rates of highly competitive species and subsequently decrease species richness.

\section{Comparisons with an Adjacent \\ Reference Plant Community}

Native reference areas have been used as a standard to evaluate reclamation success for many reclamation projects (Chambers et al. 1994). Additionally, reference areas represent an objective standard against which the relative success of initial revegetation techniques can be evaluated.

Comparisons between mean total aboveground biomass on plots seeded to the 3 seed mixtures after 20 years differed from that of the reference plant community (Table 5). Mean total biomass (averaged over the years $1987,1989,1991$, and 1992) on the undisturbed area was $149 \mathrm{~g}$ $\mathrm{m}-2$. Total biomass in plots seeded to the combination and introduced seed mixtures were both less than the reference plant community (Table 5 ). However, total biomass in the native mixture was similar to the reference area.

Table 5. Mean and \% production for each seed mixture by life form versus the undisturbed reference area. Means are presented in $\mathrm{g} \mathrm{m}^{-2}$. Standard error's (s.e.) are also given for each percentage value.

\begin{tabular}{lcccccccc}
\hline \hline \multirow{2}{*}{$\begin{array}{l}\text { Cife } \\
\text { Form }\end{array}$} & \multicolumn{2}{c}{ Combination } & \multicolumn{2}{c}{ Native } & \multicolumn{2}{c}{ Introduced } & \multicolumn{2}{c}{ Undisturbed } \\
\cline { 2 - 8 } & Mean & $\%($ s.e. $)$ & Mean & $\%($ s.e. $)$ & Mean & $\%($ s.e.) & Mean & $\%($ s.e. $)$ \\
\hline & $\left(\mathrm{g} \mathrm{m}^{-2}\right)$ & & $\left(\mathrm{g} \mathrm{m}^{-2}\right)$ & & $\left(\mathrm{g} \mathrm{m}^{-2}\right)$ & & $\left(\mathrm{g} \mathrm{m}^{-2}\right)$ & \\
Grass & $79^{*}$ & $74(3)$ & $93^{*}$ & $71(3)$ & $90^{*}$ & $86(2)$ & 32 & $21(4)$ \\
Forb & 10 & $9(1)$ & 18 & $12(2)$ & 11 & $10(1)$ & 13 & $11(3)$ \\
Shrub & $19^{*}$ & $17(3)$ & $26^{*}$ & $17(3)$ & $4^{*}$ & $4(1)$ & 104 & $68(5)$ \\
Total & $108^{*}$ & 100 & 137 & 100 & $105^{*}$ & 100 & 149 & 100 \\
\hline
\end{tabular}

*Significantly different than the corresponding (same row) undisturbed reference area means at the 0.05 level.

The combination seed mixture produced similar total biomass as the reference plant community when irrigated, but less biomass when non-irrigated. Conversely, the introduced mixture produced less biomass than the reference area when irrigated, but similar biomass when non-irrigated. The native mixture, however, produced similar total biomass as the reference plant community on both irrigated and non-irrigated plots.

A relative comparison of life forms between the 1997 results of the experimental plots and the reference area may provide greater insight into plant community development. In terms of relative composition by life form, grass biomass represented $21 \%$ of the total production in the reference area, whereas forb and shrub biomass represented $11 \%$ and $68 \%$, respectively (Table 5 ). In contrast, plots seeded with the combination seed mixture had $74 \%$ grass biomass, $9 \%$ forb biomass, and $17 \%$ shrub biomass (Table 5 ). Similarly, the native seed mixture supported $71 \%$ grass biomass, $12 \%$ forb biomass, and $17 \%$ shrub biomass. Plots seeded with the introduced seed mixture had $86 \%$ grass biomass, $10 \%$ forb biomass, and only $4 \%$ shrub biomass (Table 5 ). Thus, on a relative biomass by life form basis, all 3 seed mixtures evaluated were dissimilar to the reference plant community after 20 years of plant community development.

The native and combination seed mixtures (regardless of irrigation treatment, seeding technique, and fertilization) closely resembled the reference area in terms of species richness. The mean number of species per plot (4 replicate plots sampled, each $500 \mathrm{~m}^{2}$ in area and sampled with ten, $0.5 \mathrm{~m}^{2}$ quadrats for a total area sampled of $5 \mathrm{~m}^{2}$ ) in the reference area was 5.6 species $\mathrm{m}^{-2}$. The maximum species richness obtained in any given seed mixture (averaging over all other treatments) in the experimental plots (48 plots; each $48 \mathrm{~m}^{2}$ in area and sampled with five, $0.5 \mathrm{~m}^{2}$ quadrats for a total area sampled of 2.5 $\mathrm{m}^{2}$ ) was 4.8 species $\mathrm{m}^{-2}$ in the native seed mixture. Similarly, the combination seed mixture yielded 4.2 species $\mathrm{m}^{-2}$. However, the introduced seed mixture yielded only 2.8 species $\mathrm{m}^{-2}$. Thus, species richness for both the native and combination seed mixtures was found to be qualitatively similar to the reference area after 20 years of plant community development, but lower for the introduced seed mixture.

\section{Conclusion}

Our results demonstrate that initial cultural practices can influence long-term plant community development over time. The original species seeded in each seed mixture evaluated have remained persistent over 20 years, especially on plots seeded with the combination and native seed mixtures. Therefore, we conclude that (1) initial seeding (within the limits of the species seeded in this study) of a disturbed semi-arid sagebrush site inhibited colonization of neighboring species, (2) initial irrigation increases the long-term productivity of the native seed mixture used in this study (especially forb and shrub species), (3) the 3 seed mixtures, despite inhibiting further colonization, have resulted in distinctly different plant communities after 20 years, and (4) broadcast seeding a native seed mixture that has been irrigated for 2 growing seasons without fertilization appears to be an effective long-term combination of cultural revegetation practices. These results lead us to hypothesize that (1) succession on re-seeded, severely disturbed sites in the semiarid intermountain west may closely resemble the "inhibition" model of plant succession originally described by Connell and Slatyer (1977), (2) barring any further disturbance, re-seeded sites may remain in a steady-state as defined by the ST model developed by Allen-Diaz and Bartolome (1998), and (3) secondary succession may differ between disturbed-non seeded sites and disturbed-re-seeded sites in the intermountain west. 


\section{Literature Cited}

Allen-Diaz, B. and J.W. Bartolome. 1998. Sagebrush-grass vegetation dynamics: Comparing classical and state-transition models. Ecol. Applic. 8:795-804.

Biondini, M. and E. F. Redente. 1986. Interactive effect of stimulus and stress on plant community diversity in reclaimed lands. Reclam. Reveg. Res. 4: 211-222.

Chambers, J., R. Brown and B. Williams. 1994. An evaluation of reclamation success on Idaho's phosphate mines. Rest. Ecol. 2: 4-16.

Connell, J.H. and R.O. Slatyer. 1977. Mechanisms of succession in natural communities and their role in community stability and organization. Amer. Natur. 111:1119-1143.

DePuit, E. J. 1984. Potential topsoiling strategies for enhancement of vegetation diversity on mined lands. p. 258-272 In: Third biennial symposium on surface coal mine reclamation on the Great Plains, Billings, Mont.

DePuit, E. J. 1988. Productivity of Reclaimed Lands - Rangelands. p. 93-129 In: L. R. Hossner, ed. Reclamation of Surface-Mined Lands. CRC Press, Inc., Boca Raton, Fla.

DePuit, E. J. and J. G. Coenenberg. 1979. Methods for establishment of native plant communities on topsoiled coal stripmine spoils in the Northern Great Plains. Reclam. Rev. 2: 75-83.

DePuit, E. J., C. L. Skilbred, and J. G. Coenenberg. 1982. Effects of two years of irrigation on revegetation of coal surfacemined land in South-Eastern Montana. J. Range Manage. 35: 67-74.

Doerr, T. B. and E. F. Redente. 1983. Seeded plant community changes on intensively disturbed soils as affected by cultural practices. Reclam. and Reveg. Res. 2: 13-24.

Doerr, T. B., E. F. Redente, and T. E. Sievers. 1983. Effect of cultural practices on seeded plant communities on intensively disturbed soils. J. Range Manage. 36: 423-428.
Eissenstat, D. M. and M. M. Caldwell. 1988. Competitive ability is linked to rates of water extraction: A field study of two aridland tussock grasses. Oecologia 63:153-158.

Farmer, E. E., R. W. Brown, B. Z. Richardson, and P. E. Packer. 1974. Revegetation research on the Decker Coal Mine in southeastern Montana. USDA Forest Service. Rep. INT-162. Ogden, Ut.

Hatton, T. J. and N. E. West. 1987. Early seral trends in plant community diversity on a recontoured surface mine. Vegetatio 73 : 21-29.

Huston, M. 1979. A general hypothesis of species diversity. The Amer. Natur. 113: 81-101.

Knabe, W. 1965. Observations on world-wide efforts to reclaim industrial waste land. Symposium of the Brit. Ecol. Soc. 5: 263-296.

Kuehl, R.O. 1994. Statistical principles of research design and aalysis. 2nd ed. Duxburg/Thompson Learning, Pacific Grove, Calif.

May, M., R. Lang, L. Lujan, P. Jacoby, and W. Thompson. 1971. Reclamation of strip mine spoil banks in Wyoming. Univ. of Wyo., Laramie, Wyo.

National Research Council. 1994. Rangeland Health: New methods to classify, inventory, and monitor rangelands. Nat. Acad. Press, Wash., D.C.

Redente, E., and E. DePuit. 1988. Reclamation of drastically disturbed rangelands. $p$. 559-584 In: P. Tueller, ed. Vegetation science applications for rangeland analysis and management. Klewer Acad. Publ., Boston, Mass.

Redente, E. F., T. McLendon, and W. Agnew. 1997. Influence of topsoil depth on plant community dynamics of a seeded site in northwestern Colorado. Arid Soil Res. and Rehab. 11:139-149.

Redente, E. F., T. B. Doerr, C. E. Grygiel, and M. E. Biondini. 1984. Vegetation establishment and succession on disturbed soils in northwest Colorado. Reclam. and Reveg. Res. 3:153-165.
Ries, R. E. and A. D. Day. 1978. Use of irrigation in reclamation in dry regions. $p$. 505-520 In: F. W. Schaller and P. Sutton eds. Reclamation of drastically disturbed lands. Amer. Soc. of Agron., Crop Science Soc. of Amer., and Soil Sci. Soc. of Amer., Madison, Wis.

SAS Institute. 1989-1996. SAS Institute, Cary, N. C.

Sindelar, B. W. 1980. Achicving revegetation standards on surface mined lands. Adequate reclamation of mined lands? - A symposium. Soil Conserv. Soc. of Amer., Western Agr. Exp. Sta., Billings, Mont.

Surface Mining Control and Reclamation Act, 1977. Surface mining control and reclamation act. P. L. 95-83.

Stark, J. M., and E. F. Redente. 1985. Soilplant diversity relationships on a disturbed site in northwestern Colorado. Soil Sci. Soc. of Amer. J. 49:1028-1034.

Steele, R. G. D. and J. H. Torrie. 1980. Principles and procedures of statistics: A biometrical approach. Second Ed. McGraw-Hill, Inc. New York, N. Y.

Sydnor, R. 1999. An evaluation of long-term plant community development on topsoil treatments overlying retorted oil shale. M.S. Thesis. Rangeland Ecosystem Sci. Dept., Colo. State Univ., Fort Collins, Colo.

Tiedeman, J.A. and C. Terwilliger. 1978. Phyto-edaphic classification of the Piceance Basin. Range Sci. Dept., Colo. State Univ., Fort Collins, Colo. $265 \mathrm{p}$.

Walker, S. C., R. Stevens, S. B. Monsen, and K. R. Jorgensen. 1995. Interaction between native and seeded introduced grasses for 23 years following chaining of Juniper-Pinyon woodlands. p. $372-380$. In: Proceedings: Wildland shrub and arid land restoration symposium. Intermountain Res. Sta., U.S. Forest Service, USDA, Las Vegas, Nev.

West, N. 1993. Biodiversity of rangelands. J. Range Manage. 46: 2-13. 


\section{Book Review}

The View From Bald Hill: Thirty Years in an Arizona Grassland. By Carl E. Bock and Jane H. Bock. 2000. University of California Press, Berkeley. $197 \mathrm{p}$. US $\$ 16.95$ paper ISBN 0-520-22184-2.

The first domestic livestock animal was introduced into the American Southwest by Francisco Vasquez de Coronado in 1540. Since then, cattle, horses, and sheep have played a major role in shaping the ecological character of the arid grasslands of the Southwest. The Appleton-Whittell Research Ranch is an approximately 8,000-acre refuge in which grazing has been prohibited since 1968. Carl and Jane Bock use the 14 chapters of this book to describe the results of 30 years of field research concerning the dynamics of grasslands in the absence of livestock grazing. Rather than furnish a tedious chapter by chapter review, in what follows, I shall concentrate on 5 of the book's most thought provoking chapters. This should provide the reader with a good idea of the intellectual contributions of this book.

Burroweed, a small native shrub that is very familiar in certain parts of the Sonoita Valley, is the subject of Chapter 2. The authors ask the following question: Is the abundance of burroweed a consequence of historic livestock grazing in this region or is this copiousness due to alternate factors? On the basis of data from the Research Ranch and from grazed areas, the authors conclude that "the current population dynamics of this shrub are much more related to fire and weather than to livestock activities" (p. 15). This is a stimulating chapter and the authors rightly note the extent to which the preceding conclusion is based on the presence of data from the Research Ranch. However, a potentially disquieting feature of this chapter is the emphasis it places on the fact that the Research Ranch is largely untouched by human actions. Although there is a long tradition in ecology of studying sites devoid of human influence, in recent times, some ecologists (see the paper by Robert O'Neill and James Kahn in BioScience, Vol. 50, pp. 333-337, 2000 ), have rightly pointed to the limited usefulness of studying "worlds" without humans. In fact, the noted ecologist David Tilman has said that ecology is a discipline headed toward extinction if it persists in studying species living in habitats with little or no human influence (see p. 909 of the paper by G. Brown in the Journal of Economic Literature, Vol. 38 , pp. 875-914, 2000).

The authors use their extensive field research to shed light on the following question in Chapter 4: after 30 years without livestock grazing, how have the grasslands on the Research Ranch changed compared to those of the surrounding cattle ranches? On the basis of some interesting assumptions, the authors reach 3 conclusions. First, we are told that grasslands "having a prehistoric association with bison... are relatively tolerant of the effects of livestock" (p. 43). Second, it is noted that livestock "are neither universally beneficial nor absolutely harmful to vegetation and wildlife" (p. 43). Finally, it is pointed out that there "is no need for absolute exclusion of livestock from public lands" (p. 44). These are all worthwhile points and they deserve to have been made. My only comment about this chapter concerns the occasional overzealous sentence. For instance, on p. 42 , the authors say that suburbanization, energy extraction, and old growth logging are all examples of unsustainable land uses. First, it's not obvious what the authors mean by unsustainable. Second, it would be nice to show and not simply claim that the above land uses are unsustainable.

Chapter 8 discusses, inter alia, the role that sparrows play in providing information about the status of the grassland communities of which they are a part. This is a fascinating chapter and it makes a number of useful points about the nexuses between sparrows, sacaton, and watershed destruction due to grazing. As the authors point out, sparrows are "individually powerful indicators of environmental condition...[and] they appear to be key players in the dynamics of [southwestern] grasslands as well" (p. 98).

Are plains lovegrass plants susceptible to drought? Do fires reduce the susceptibility of plains lovegrass to drought? Finally, does grazing reduce the susceptibility of plains lovegrass to drought? These questions are addressed in Chapter 11. Specifically, it is noted that "fires in some way protect plants against the effects of droughts..." (p. 125) and that livestock "grazing also reduces drought-caused mortality..." (p. 125). The authors point out that they can find no evidence to suggest that plains lovegrass plants are increasing steadily toward any sort of long-term population stability. This is consistent with the arguments put forth in the well known paper on rangeland management by Marc Westoby, Brian Walker, and Imanuel NoyMeir (see their paper in the Journal of Range Management, Vol. 42, pp. 266-274, 1989); as such, it would have been nice if the authors had commented on this connection.

Chapter 13 contains an animating discussion of the effects of species introductions. It is noted that the establishment and the spread of alien species has the potential to imperil the biological diversity and the ecological character of the Research Ranch. Following this, the authors provide 5 interesting answers to the question as to why it would be unfortunate if the native grasslands of the Sonoita Valley were to be displaced by lovegrass native to southern Africa. One of the answers is that we "would lose things we will need in the future" (p. 145, emphasis added). Although the authors make claims about the "immeasurable potential value" of the native animals and the plants, they do not do an adequate job of showing that we will, in fact, need the things that they say we will.

Let me conclude this review by pointing out that in general, this book contains an engaging account of the benefits of longterm field research into the dynamics of grasslands in the absence of livestock grazing. In addition to this, the book makes intelligent remarks on some salient but fractious public policy issues concerning the use of our environmental resources. As such, I recommend this book to readers who wish to learn more about the nexuses between extended field research, the intertemporal behavior of grasslands, and conservation policy.-Amitrajeet A. Batabyal, Rochester Institute of Technology, Rochester, New York. 


\section{JRM Table of Contents Volume 54, 2001}

January 2001

Feature Article

2 Viewpoint: The response of central North American prairies to seasonal fire by David $M$. Engle and Terrence G. Bidwell

Animal Ecology

11 Prairie dog effects on harvester ant species diversity and density by Justin E. Kretzer and Jack F. Cully, Jr.

15 Coyote responses to changing jackrabbit abundance affect sheep predation by L. Charles Stoddart, Richard E. Griffiths, and Frederick F. Knowlton

21 Assessing independence of animal locations with association matrices by Keith T. Weber, Milo Burcham, and C. Les Marcum

Grazing Management

25 Sheep grazing spotted knapweed and Idaho fescue by Bret $\mathrm{E}$. Olson and Roseann T. Wallander

31 Range condition, tenure, management, and bio-physical relationships in Sonora, Mexico by Jose A. Coronado-Quintana and Mitchel P. McClaran

39 Rotationally stocked beef cattle responses to daily and weekly residence by N.S. Boyd, T. Astatkie, A.H. Fredeen, and R.C. Martin

Hydrology

44 Variations in soil moisture content in a rangeland catchment by Rohit Salve and Barbara Allen-Diaz

Improvement

52 Spotted knapweed response to season and frequency of mowing by Matthew J. Rinella, James S. Jacobs, Roger L. Sheley, and John J. Borkowski

Measurement/Sampling

57 Estimating herbage standing crop with visual obstruction in tallgrass prairie by Lance $\mathrm{T}$. Vermeire and Robert L. Gillen

61 Detecting fragmentation of cover in desert grasslands using line intercept by Robert $O$. Kuehl, Mitchel P. McClaran, and Justin Van Zee

67 Estimation of horizontal cover by William B. Collins and Earl F. Becker

\section{Plant/Animal}

71 Dry-weight-rank method assessment in heterogenous communities by Steven L. Dowhower, W. Richard Teague, R. James Ansley, and William E. Pinchak
77 Animal age and sex effects on diets of grazing cattle by E.E. Grings, R.E. Short, M.R. Haferkamp, and R.K. Heitschmidt

82 Nutritive value and aversion of honey mesquite leaves to sheep by R. Baptista and K.L. Launchbaugh

Plant Ecology

89 Effects of biosolids on tobosagrass growth in the Chihuahuan desert by Pedro Jurado and David B. Wester

Book Review

96 Riding the Higher Range: The Story of Colorado's Coleman Ranch and Coleman Natural Beef by Stephen M. Voynick

March 2001

Feature Article

98 Vegetation and water yield dynamics in an Edwards Plateau watershed by X. Ben Wu, Eric J. Redeker, and Thomas L. Thurow

106 Economics and demographics constrain investment in Utah private grazing lands by Regina Peterson and D. Layne Coppock

115 Range research: The second generation by James $A$. Young and Charlie D. Clements

Grazing Management

122 Paddock shape effects on grazing behavior and efficiency in sheep by Agostino Sevi, Antonio Muscio, Delia Dantone, Vincenzo Lascone, and Francesco D'Emilio

126 Cover for wildlife after summer grazing on Sandhills rangeland by Patrick E. Reece, Jerry D. Volesky, and Walter H. Schacht

132 Sequential sampling protocol for monitoring pasture utilization using stubble height criteria by David $\mathrm{L}$. Turner and Warren P. Clary

138 Chain diker effects on seeded grass establishment following disk chaining by H.T. Wiedemann and B.T. Cross

Improvements

144 Revegetating spotted knapweed infested rangeland in a single entry by Roger L. Sheley, James S. Jacobs, and Daniel E. Lucas

Measurement/Sampling

152 Intermountain plant community classification using Landsat TM and SPOT HRV data by Patrick E. Clark, Mark S. Seyfried, and Bob Harris
Plant/Animal

161 Supplemental polyethylene gl influences preferences of g، browsing blackbrush by Christo H. Titus, Frederick D. Provenza, Perevolotsky, Nissim Silanikove, Jozo Rogosic

166 Demographic characteristics Artemisia tridentata Nutt. subspi by Barry L. Perryman, Aaror Maier, Ann L. Hild, and Richar Olson

Plant Ecology

171 Observation: Long-term incre in mesquite canopy cover i North Texas savanna by $R$. Ja Ansley, $\mathrm{X}$. Ben $\mathrm{Wu}$, and Bett: Kramp

177 Relationship between plant spr diversity ad grassland conditio: Yuguag Bai, Zoheir Abouguer and Robert E. Redmann

Soils

184 Cattle treading effects on sedir loss and water infiltration by Russell, K. Betteridge, D.A. Co: and A.D. MacKay

Technical Notes

191 A simple method for preparing erence slides of seed by Mari Dacar, and Stella M. Giannoni

194 Physical and chemical compari between microphytic and $\mathrm{r}$ microphytic soil seedbeds by $R$ R. Blank, Fay L. Allen, and Jame Young

197 Early harvest of squirreltail see Paul S. Doescher

Book Review

200 Dynamic State Variable Mode Ecology: Methods and Applicat by Cohin W. Clark and Marc Mar

Synopsis Papers of Remote Sen. Symposium

201 Remote Sensing/GIS Symposiur

202 A method to incorporate pheno into land cover analysis by Keit Weber

203 Airborne LASER technology measuring rangeland condition Jerry C. Ritchie, Mark S. Seyfried, I J. Chopping, and Yakov Pachepsky

204 Stream change analysis us remote sensing and geogral information systems (GIS) Andrea S. Laliberte, Dougla Johnson, Norman R. Harris, Grant M. Casady 
205 Responses of elk and mule deer to cattle in summer by Priscilla K. Coe, Bruce K. Johnson, John W. Kern, Scott L. Findholt, John G. Kie, and Michael J. Wisdom

206 Remote Sensing of Range Production and Utilization by Paul T. Tueller

207 Mapping weekly rangeland vegetation productivity using MODIS algorithms by Matthew C. Reeves, Jerome C. Winslow, and Steven W. Bunning

208 Reflectance and image characteristics of selected noxious rangeland species by J.H. Everitt, D.E. Escobar, and M.R. Davis

May 2001

Feature Article

210 Application of non-equilibrium ecology to rangeland riparian zones by Tamzen K. Stringham, William C. Krueger, and David R. Thomas

Animal Ecology

218 Activity budgets and foraging behavior of bison on seeded pastures by Bruce D. Rutley and Robert J. Hudson

226 Breeding bird responses to juniper woodland expansion by Steven $S$. Rosenstock and Charles Van Riper III

Animal Physiology

233 Escape protein and weaning effects on calves grazing meadow regrowth by Gregory P. Lardy, Don C. Adams, Terry J. Klopfenstein, Richard T. Clark, and June Emerson

Grazing Management

239 Comparative rumen and fecal diet microhistological determinations of European mouflon by Jean-Louis Chapuis, Patrick Boussés, Benoît Pisanu and Denis Réale

243 Herbage response to precipitation in central Alberta boreal grasslands by Edward W. Bork, Tamiko Thomas, and Brent McDougall

249 The nutritive quality of cholla cactus as affected by burning by J.E. Sawyer, L.A. Knox, G.B. Donart, and M.K. Petersen

Measurement/Sampling

254 Remote sensing of redberry juniper in the Texas rolling plains by J.H. Everitt, C. Yang, B.J. Racher, C.M. Britton, and M.R. Davis

Plant/Animal

260 Characteristics of nest sites of northern bobwhites in western Oklahoma by Darrell E. Townsend II, Ronald E. Masters, Robert L. Lochmiller, David M. Leslie, Jr., Stephen J. Demaso, and Alan D. Peoples
265 Research Observation: Cattle preference for Lambert locoweed over White locoweed by Michael $\mathrm{H}$. Ralphs, Gary Greathouse, Anthony P. Knight, and Lynn James

269 Antelope bitterbrush seed production and stand age by Charlie D. Clements and James A. Young

274 Activated charcoal and experience affect intake of juniper by goats by Matthew G. Bisson, Cody B. Scott, and Charles A. Taylor, Jr.

279 Canadian bluejoint response to heavy grazing by William $B$. Collins, Earl F. Becker, and Alison B. Collins

Plant Ecology

284 Restoring degraded riparian meadows: Biomass and species responses by David W. Martin and Jeanne C. Chambers

292 Drought and grazing III: Root dynamics and germinable seed bank by A.L. Hild, M.G. Karl, M.R. Haferkamp, and R.K. Heitschmidt

299 Forage kochia seed germination response to storage time and temperature by Stanley G. Kitchen and Stephen B. Monsen

Reclamation

307 Species composition on reclaimed ski runs compared with unseeded areas by Ron J. Van Ommeren

Book Reviews

312 Warming the World: Economic Models of Global Warming by William D. Nordhaus and Joseph Boycr; Tropical Forage Plants: Development and Use, edited by Antonio Sotomayor-Rio and W.D. Pitman.

July 2001

Feature Article

314 Ranching motivations in 2 Colorado Counties by Helen Ivy Rowe, E.T. Bartlett, and Louis E. Swanson, Jr.

322 Economic analysis of using sheep to control leafy spurge by Dean $A$. Bangsund, Dan J. Nudell, Randall S. Sell, and F. Larry Leistritz

Grazing Management

330 Dietary structural types of polygastric herbivores at different environments and seasons by Alicia Pelliza, Priscila Willems, and Marcela Manacorda

338 Cattle use of foothills rangeland near dehydrated molasses supplement by Derek W. Bailey, G. Robert Welling, and Eric T. Miller

348 Complementary grazing of native pasture and Old World bluestem by Robert L. Gillen and William A. Berg
Hydrology

356 Upland erosion under most damaging storm D.E. Mergen, J.L. Sm Trlica

Improvements

362 Restoring tallgrass pr mixtures on leafy $\mathrm{sp}$ rangeland by Robert Daniel D. Beran, and Ror

Measurement/Sampling

370 Statistical analyses of data from chlorofor lamb feces by $A$. Muk Anderson, D.L. Daniel, G. Tisone, E.L. Fredr Estell, G.D. Rayson Havstad

378 A proposed method for shrub utilization usi imagery by Mark C. Q Jo Anderson

Plant/Animal

382 Low density of prickly sheep grazing in $\mathrm{Qu}$ Fleur Tiver, Mike Nicl Kriticos, and Joel R. Brc

\section{Plant Ecology}

390 Endophytic fungi in rye in natural grassla Ann Vinton, Emily S. Ki P. Vogel, and Andrew A

Reclamation

396 'Immigrant' forage ko bility as impacted by $\mathrm{s}$ ods by Alison Stew Anderson, and Stanley C

Soils

400 Carbon and nitrogen $\mathrm{dy}$ winter ranges by $\mathrm{R}$ Menezes, Edward T. Ell. Valentine, and Stephen $t$ Symposium Papers

409 Anti-quality componer Overview, significan nomic impact by Vivic and Eduardo Segarra

413 Structural anti-quality tics of range and past Emilio A. Laca, Lisa A Edward D. Reid

420 Lignin and fiber d Kenneth J. Moore and G. Jung

431 Herbivore response to factors in forage: Launchbaugh, F.D. P1 J.A. Pfister

441 Animal health probler silicon and other mi ances by Henry $F$. A Glenn E. Shewmaker 
447 Alkaloids as anti-quality factors in plants on western U.S. rangelands by James A. Pfister, Kip E. Panter, Dale R. Gardner, Bryan L. Stegelmeier, Michael H. Ralphs, Russell J. Molyneux, and Stephen T. Lee

462 Anti-quality effects of insects feeding on rangeland plants: $A$ review by John B. Campbell

466 Effects of proanthocyanidins on digestion of fiber in forages by Jess D. Reed

474 Anti-quality factors associated with alkaloids in eastern temperate pasture by F.N. Thompson, J.A. Stuedemann, and N.S. Hill

490 Practical measures for reducing risk of alfalfa bloat in cattle by Walter Majak, John W. Hall, and Tim A. McAllister

494 Review of toxic glycosides in rangeland and pasture forages by Walter Majak

Book Review

499 The New Ranch Handbook: A Guide to Restoring Western Rangelands by Nathan F. Sayre, edited by Barbara H. Johnson

\section{September 2001}

Invited Synthesis Paper

502 Principles and practices for managing rangeland invasive plants by Robert A. Masters and Roger L. Sheley

Feature Article

518 Community characteristics of oldgrowth western juniper woodlands by Wendy Sims Waichler, Richard F. Miller, and Paul S. Doescher

528 Spatial modeling of rangeland potential vegetation environments by Mark E. Jensen, Jeff P. DiBenedetto, James A. Barber, Cliff Montagne, and Patrick S. Bourgeron

Animal Ecology

537 Characterization and habitat preferences by white-tailed deer in Mexico by Joaquin Bello, Sonia Gallina, and Miguel Equihua

546 Grassland birds associated with agricultural riparian practices in southwestern Wisconsin by Rosalind B. Renfrew and Christine A. Ribic

553 Economics of managing mesquite in north Texas: a sensitivity analysis by W. R. Teague, R.J. Ansley, U. P. Krueter, W. E. Pinchak, and J. M. McGrann

Grazing Management

561 Resilience of prickly burnet to management in east Mediterranean rangelands by $A$. Perevolotsky, G. Ne'eman, R. Yonatan, and Z. Henkin
Hydrology

567 Hydrologic responses of a montane riparian ecosystem following cattle use by M. Flenniken, R. R. McEldowney, W. C. Leininger, G. W. Frasier, and M. J. Trlica

Improvements

575 Seed recovery and germination of reseeded species fed to cattle by $K$. M. Doucette, K. M. Wittenberg, and W. P. McCaughey

Measurement/Sampling

582 Evaluation of 3 techniques for determining diet composition by $S$. R. Henley, D. G. Smith and J. G. Raats

589 Point sampling for leaf area index in sagebrush steppe communities by Patrick E. Clark and Mark S. Seyfried

Plant/Animal

595 Bitterbrush and cheatgrass quality on 3 southwest Idaho winter ranges by Chad J. Bishop, Edward O. Garton, and James W. Unsworth

Plant Ecology

603 Redberry juniper canopy cover dynamics on western Texas rangelands by Darrell N. Ueckert, Robert A. Phillips, Joseph L. Petersen, X. Ben $\mathrm{Wu}$, and Daniel F. Waldron

611 Quantifying suitable habitat of the threatened western prairie fringed orchid by Paige M. Wolken, Carolyn Hull Sieg, and Stephen E. Williams

617 Effect of fire on perennial grasses in central semiarid Argentina by Daniel V. Peláez, Roberto M. Bóo, Mirta D. Mayor, and Omar R. Elia

622 Autumn and spring drought periods affect vegetation on high elevation rangelands of Turkey by Ali Koç

Book Reviews

628 Stolen Harvest: The Hijacking of the Global Food Supply by Vandana Shiva

November 2001

Feature Article

630 Adoption of Brush Busters: Results of Texas county extension survey by Urs P. Kreuter, Heidi E. Amestoy, Darrell N. Ueckert, and Allan McGinty Grazing Management

640 Nutritional dynamics of 7 northern

Great Basin grasses by Dave Ganskopp and Dave Bohnert

648 Influence of off-stream supplements on streambanks of riparian pastures by Michael L. McInnis and James McIver

Measurement/Sampling

653 Frequency grid-a simple tool for measuring grassland establishment by Kenneth P. Vogel and Robert A. Masters
Plant/Animal

656 Suppression of ann impacts rangeland: responses by Marshall $R$ R.K. Heitschmidt, Elair Michael D. MacNeil, an Karl

663 Suppression of annı impacts rangeland: $A$ ni es by Marshall R. Hafer E. Grings, R.K. Heitschr D. MacNeil, and Michael

Plant Ecology

669 Chemical composition : ingestion of carob (Cerc L.) seeds by Moh'd Shatnawi, and Khalil I. E

674 Adaptation of perennia the eastern Central Gr Kenneth P. Vogel and Ke

680 Mesquite and grass i with establishing redb seedlings by W.R. T Dowhower, S.G. Whise Flores-Ancira

685 Effects of prescribed shinnery oak communi C. Harrell, Samuel D. Fu Terrence G. Bidwell

691 Juniper encroachment i the Northwest Great Ba G. Wall, Richard F. Mill J. Svejcar

699 Climatic influences on of 3 subspecies of Arte tata by Aaron M. Mai Perryman, Richard A. OI L. Hild

Soils

704 Grazing impacts on $s$ and phosphorus unde pastures by V.S. Baron E. Mapfumo, S.S. Malhi, and D.S. Chanasyk

711 Tracked vehicle impac tion structure and soil e William P. Grantham Redente, Calvin F. Baglı W. Paschke

Reclamation

717 Long-term plant comm opment as influenced I tion techniques by Newman and Edward F.

Book Reviews

725 The View From Bald Years in an Arizona $\mathbf{G}$ Carl E. Bock and Jane H. 


\section{Journal of Range Management Index, Volume 54, 2001}

\section{A}

Abouguendia, Zoheir, 177

Accuracy assessment, 254

Acid detergent, 466

Activated charcoal and experience affect intake of juniper by goats, 274

Activity budgets and foraging behavior of bison on seeded pastures, 218

Adams, Don C., 233

Adaptation of perennial triticeae to the eastern Central Great Plains, 674

Adaptive management, 502

Adoption of Brush Busters: Results of Texas county extension survey

Aeration, 284

Aerial photography, 171, 603

After-ripening, 299

Age structure, 691

Agency and industry partnerships, 630

Agropyron, 674 spicatum, 641

Airborne LASER technology for measuring rangeland conditions, 203

Alien plants, 502

Alkaloids as anti-quality factors in plants on western U.S. rangelands, 447

Allen, Fay L., 194

Allen, Vivien Gore, 409

Allen-Diaz, Barbara, 44

Amestoy, Heidi E., 630

Ammonium, 194, 704

Anderson, D.M., 370

Anderson, Val Jo, 378, 396

Animal age and sex effects on diets of grazing cattle, 77

Animal health, 409

Animal health problems caused by silicon and other mineral imbalances, 441

Annual grazing, 218 ryegrass, 474

Ansley, R. James, 71, 171, 553

Antelope bitterbrush seed production and stand age, 269

Anti-quality, 420, 431

Anti-quality components in forage: Overview, significance, and economic impact, 409

Anti-quality effects of insects feeding on rangeland plants: A review, 462

Anti-quality factors associated with alkaloids in eastern temperate pasture, 474

Application of non-equilibrium ecology to rangeland riparian zones, 210

Arid lands, 711

Arizona, 226

Artemisia arbuscula, 589

Artemisia tridentata ssp. vaseyana, 589
Artemisia tridentata ssp. wyomingensis, 589

Assessing independence of animal locations with association matrices, 21

Astatkie, T., 39

Autumn and spring drought periods affect vegetation on high elevation rangelands of Turkey, 622

Autumn visual obstruction, 126

Average daily gain, 39

Aversions, 274

Avian communities, 226

\section{B}

Bagley, Calvin F., 711

Bai, Yuguang, 177

Bailey, Derek W., 338

Bangsund, Dean A., 322

Baptista, R., 82

Barber, James A., 528

Baron, V.S., 704

Bartlett, E.T., 314

Becker, Earl F., 67, 279

Beef

calves, 233

cattle, 77

Behavior, 338

Bello, Joaquin, 537

Beran, Daniel D., 362

Berg, William A., 348

Betteridge, K., 184

Bidwell, Terrence G., 2, 685

Big

eyed bugs, 462

sagebrush, 166, 699

Bioeconomics, 553

Biological control, 502

Biomass, 177, 622

Biosolids land-application, 89

Biosolids surface-application, 89

Bishop, Chad J., 595

Bisson, Matthew G., 274

Bite size, 413

Bitterbrush and cheatgrass quality on 3 southwest Idaho winter ranges, 595

Blank, Robert R., 194

Bobwhite, 260

Bohnert, Dave, 640

Bóo, Roberto M., 617

Book Reviews, 96, 200, 312, 499, 628, 717

Boreal forest, 279

Bork, Edward W., 243

Borkowski, John J., 52

Botanical composition, 71, 371, 622

Botanical diet composition, 330

Bothriochloa, 348

Bourgeron, Patrick S., 528
Boussés, Patrick, 239

Boyd, N.S., 39

Breeding bird responses to juniper woodland expansion, 226

Britton, C.M., 254

Bromus

japonicus, 656, 663

tectorum, 595, 641

Brown, Joel R., 382

Browse, 82, 269

Browsing, 274

Brush

control, 139

management, $98,553,630$

Buffer strips, 546

Buffering, 15

Burcham, Milo, 21

\section{C}

Calamagrostis canadensis, 279

Calf, 77

California rangelands, 44

Campbell, John B., 462

Canadian bluejoint response to heavy grazing, 279

Canis latrans, 15

Canonical Correspondence Analysis (CCA), 177

Canopy, 184 structure, 413

Capra, 274

Carbon and nitrogen dynamics in elk winter ranges, 400

Carex, 400

Carry-over effects, 89

Casady, Grant M., 204

Cattle, 371, 382, 494

digestion, 575 grazing, 265

Cattle treading effects on sediment loss and water infiltration, 184

Cattle use of foothills rangeland near dehydrated molasses supplement, 338

Centaurea maculosa, 25, 52

Cervus elaphus, 205

Chain diker effects on seeded grass establishment following disk chaining, 138

Chambers, Jeanne C., 284

Chanasyk, D.D., 704

Chapuis, Jean-Louis, 239

Characteristics of nest sites of northern bobwhites in western Oklahoma, 260

Characterization and habitat preferences by white-tailed deer in Mexico, 537

Chemical composition and livestock ingestion of carob (Ceratonia siliqua $\mathrm{L}$.) seeds, 669

Chewing, 413 
Chihuahuan desert grassland, 89

Chopping, Mark J., 203

Clark, Patrick E., 152, 589

Clark, Richard T., 233

Clary, Warren P., 132

Clements, Charlie D., 115, 269

Climate, 699

Climatic influences on recruitment of 3 subspecies of Artemisia tridenta, 699

Clipping, 284

Coe, Priscilla K., 205

Cold-desert revegetation, 299

Colinus virginianus, 260

Collaborative marketing, 630

Collins, Alison B., 279

Collins, William B., 67, 279

Color-infrared photography, 208, 254

Communal resources, 31

Community characteristics of old-growth western juniper woodlands, 518

Comparative rumen and fecal diet microhistological determinations of European mouflon, 239

Competition, 197, 205, 680

Complementary forages, 348

Complementary grazing of native pasture and Old World bluestem, 348

Conceptualization, 330

Condensed tannins, 466

Conditioned aversion, 82

Conditioned aversions, 431

Conventional color photography, 208

Cool-season grasses, 362

Coppock, D. Layne, 106

Coronado-Quintana, Jose A., 31

Costall, D.A., 184

Cover, 52

type, 152

Cover for wildlife after summer grazing on Sandhills rangeland, 126

Coyote numerical response, 15

Coyote responses to changing jackrabbit abundance affect sheep predation, 15

Cross, B.T., 138

Crude protein, 595, 641, 663

Cully, Jack F., Jr., 11

Current year precipitation, 243

Cynomys ludovicianus, 11

\section{D}

Dacar, María A., 191

Daniel, D.L., 370

Dantone, Delia, 122

Davis, M.R., 208, 254

DeMaso, Stephen J., 260

D'Emilio, Francesco, 122

Demographic characteristics of 3 Artemisia tridentata Nutt. subspecies, 166

Demography, 166

Density, 52, 171, 546

Detecting fragmentation of cover in desert grasslands using line intercept, 61

Detoxification, 431
DiBenedetto, Jeff P., 528

Dick, A.C., 704

Diet

analysis, 239

choice, 122

selection, 77, 431, 447

Dietary structural types of polygastric herbivores at different environments and seasons, 330

Digestibility, 420

Digestion trial, 82

Digital image analysis, 254

Dissemination, 575

Distribution, 205, 338

Disturbance, 307, 691

Diversity, 11

Doescher, Paul S., 197, 518

Dominance, 546

Donart, G.B., 249

Doucette, K.M., 575

Dowhower, S.L., 680

Dowhower, Steven L., 71

Drainage density, 567

Drought and grazing III: Root dynamics and germinable seed bank, 292

Drought forages, 249

Dry-weight-rank method assessment in heterogenous communities, 71

\section{E}

Early harvest of squirreltail seed, Technical Note, 197

Earth Observing System, 207

Ecological

classification, 528

sites, 528

units, 528

Economic analysis of using sheep to control leafy spurge, 322

Economics, 322

Economics and demographics constrain investment in Utah private grazing lands, 106

Economics of managing mesquite in north Texas: a sensitivity analysis, 553

Edaphic factors, 611

Effect of fire on perennial grasses in central semiarid Argentina, 617

Effects of biosolids on tobosagrass growth in the Chihuahuan desert, 89

Effects of prescribed fire on sand shinnery oak communities, 685

Effects of proanthocyanidins on digestion of fiber in forages, 466

Ejido, 31

El-Shatnawi, Moh'd Khair J., 669

Elia, Omar R., 617

Elk, 21

Elliott, Edward T., 400

Elymus, 674

canadensis, 390

cinereus, 641

Emergency feeding, 249
Emerson, June, 233

Endophytic fungi in Canada wild rye in natural grasslands, 390

Engle, David M., 2

Eolian dust, 194

Eolian sediment, 356

Epichloë typhina, 390

Equihua, Miguel, 537

Ereifej, Khalil I., 669

Ergotism, 474

Erosion, 184, 711

Escape protein and weaning effects on calves grazing meadow regrowth, 233

Escobar, D.E., 208

Estell, R.E., 370

Estimating herbage standing crop with visual obstruction in tallgrass prairie, 57

Estimation, 71 of horizontal cover, 67

Euphorbia esula L., 322

Evaluation of 3 techniques for determining diet composition, 582

Evapotranspiration, 98

Everitt, J.H., 208, 254

Experience, 274

Facilitation, 680

Fecal fluorophores, 371

Faeces, 704

Feces, 239

Feed additives, 490

Feedback, 274

Fertilization, 561, 717

Festuca idahoensis, 25, 641

Festuca ovina, 622

Fetch length, 61

Fiber, 669

Findholt, Scott L., 205

Fire, 561

frequency, 2

intensity, 617

interactions, 2

mortality, 617

return interval, 2

Flenniken, M., 567

Flores-Ancira, E., 680

Fluorescence, 371

Forage, 441, 537

classes, 330

digestibility, 233

intake, 218,233

quality, $89,279,409,420,431,447,656$

selection, 218

utilization, 420

value, 82

yield, 674

Forage kochia seed germination response to storage time and temperature, 299

Foraging, 431

Forest, 669

Fractal, 203

Frasier, G.W., 567 
Fredeen, A. H., 39

Fredrickson, E.L., 370

Frequency grid-a simple tool for measing grassland establishment, 653

Frothy bloat, 490

Fuhlendorf, Samuel D., 685

\section{G}

GIS, 202, 204

and remote sensing, 98

Gallina, Sonia, 537

Gallinaceous, 260

Ganskopp, 640

Gardner, Dale R., 447

Garton, Edward O., 595

Gaussoin, Roch E., 362

Geographic Information System, 528

Geographic Information Systems, 204

Geographical pattern, 390

Germination, 197, 669

rate, 299

synchronization, 299

Giannoni, Stella M., 191

Gillen, Robert L., 57, 348

Glyphosate, 362

Goat, 669

Goats, 582

Grantham, William P., 711

Grasshoppers, 462

Grassland, 226 restoration, 362

Grassland birds associated with agricultural riparian practices in southwestern Wisconsin, 546

Grazing, 322, 338, 648

behavior, 431

intensity, 704

management, 122, 132, 447

pressure, 126

Grazing impacts on soil nitrogen and phosphorus under Parkland pastures, 704

Greathouse, Gary, 265

Greenline, 648

Greenstripping, 396

Griffiths, Richard E., 15

Grings, Elaine.E., 77, 656, 663

Groundwater, 210

Habitat, 260

\section{H}

selection, 205

types, 528

Haferkamp, M.R., 77, 292, 656, 663

Hall, John W., 490

Harrell, Wade C., 685

Harris, Bob, 152

Harris, Norman R., 204

Harvester ants, 462

Havstad, K.M., 370

Heifer, 77

Heitsçhmidt, R.K., 77, 292, 656, 663

Henkin, Z., 561
Henley, S.R., 582

Herbage production, 603 quantification, 207

Herbage response to precipitation in central Alberta boreal grasslands, 243

Herbicides, 502

Herbivore response to anti-quality factors in forages, 431

Herbivory, 269

Herding technology, 115

Herds, 21

Hiding cover, 537

Hilaria mutica, 89

Hild, Ann L., 166, 292, 699

Hill, N.S., 474

Hobby ranching, 107

Home range, 21

Honey mesquite, 139, 171

Hoof damage, 184

Hopkins, Andrew A., 390

Hudson, Robert J., 218

Hydrologic modeling, 98

Hydrologic responses of a montane riparian ecosystem following cattle use, 567

\section{I}

Iascone, Vincenzo, 122

Image analysis, 171

Image processing, 206

Imazapic, 362

'Immigrant' forage kochia seed viability as impacted by storage methods, 396

In vitro dry matter digestibility, 595

In vitro organic matter disappearance, 641

Influence of off-stream supplements on streambanks of riparian pastures, 648

Information dissemination, 630

Infrastructure, 31

Intake, 161

rate, 413

Integrated weed management, 502

Intermountain plant community classification using Landsat TM and SPOT HRV Data, 152

Invasive plants, 362

Irrigation, 89, 717

J. ashei, 274,

\section{$\mathbf{J}$}

$J$. pinchotii, 274

Jacobs, James S., 52, 144

James, Lynn F., 265

Jensen, Kevin J., 674

Jensen, Mark E., 528

Johnson, Bruce K., 205

Johnson, Douglas E., 204

Jordan, 669

Jung, Hans-Joachim G., 420

Juniper encroachment into aspen in the Northwest Great Basin

Juniper management, 603

Juniperus, 254, 274

monosperma, 226 occidentalis, 518

occidentalis subsp. occidentalis, 691 pinchotii, 603

Jurado, Pedro, 89

Kansas, 11

$\mathbf{K}$

Karl, M.G., 292

Karl, Michael G., 656, 663

Kathol, Emily S., 390

Kern, John W., 205

Kie, John G., 205

Kitchen, Stanley G., 299, 396

Klopfenstein, Terry J., 233

Knight, Anthony P., 265

Knowlton, Frederick F., 15

Knox, L.A., 249

KOÇ, Ali, 622

Kochia prostrata, 299, 396

Kramp, Betty A., 171

Kretzer, Justin E., 11

Kreuter, U.P., 553, 630

Kriticos, Darren, 382

Krueger, William C., 210

Kuehl, Robert O., 61

$\mathbf{L}$

LAI, 589

Laca, Emilio A., 413

Laliberte, Andrea S., 204

Land use, 107

conversion, 314

Landscape, 71, 203

Lardy, Gregory P., 233

Large-scale aerial photography, 204

Launchbaugh, K.L., 82, 431

Lee, Stephen T., 447

Legumes, 362, 490

Leininger, W.C., 567

Leistritz, F. Larry, 322

Lepus californicus, 15

Leslie, Jr., David M., 260

Lesser prairie chicken, 685

Leymus, 674

Life-stage profiles, 382

Lignin, 466

and fiber digestion, 420

Line transects, 603

Linse, S.J., 356

Litter, 177

decomposition, 400

Litterfall, 400

Livestock, 648

performance, 348

Lochmiller, Robert L., 260

Logistic regression, 611

Long-term plant community development as influenced by revegetation techniques, 717

Low density of prickly acacia under sheep grazing in Queensland, 382

Low sagebrush, 589

Lowlands, 243 
Lucas, Daniel E., 144

\section{M}

MacKay, A.D., 184

MacNeil, Michael D., 656, 663

Macronutrient status, 704

Macronutrients, 161

Maier, Aaron M., 166, 699

Majak, Walter, 490, 494

Malhi, S.S., 704

Manacorda, Marcela, 330

Mapfumo, E., 704

Mapping weekly rangeland vegetation productivity using MODIS algorithms, 207

Marcum, C. Les, 21

Martin, David W., 284

Martin, R.C., 39

Masters, Robert A., 362, 502, 653

Masters, Ronald E., 260

Maximum likelihood, 152

Mayland, Henry F., 441

Mayor, Mirta D., 617

McAllister, Tim A., 490

McCaughey, W.P., 575

McClaran, Mitchel P., 31, 61

McDougall, Brent, 243

McEldowney, R.R., 567

McGinty, Allan, 630

McGrann, J.M., 553

McInnis, Michael L., 648

McIver, James, 648

Mean germination time, 299

Mechanical brush control, 603

Mediterranean ecosystem, 561

Menezes, Rômulo S.C., 400

Mergen, D.E., 356

Mesquite and grass interference with establishing redberry juniper seedlings, 680

Mesquite rangeland, 680

Method to incorporate phenology into land cover change analysis, A, 202

Microchannels, 567

Microhistological analysis, 191, 330, 582

Micronutrients, 194

Military lands, 711

Miller, Eric T., 338

Miller, Richard F., 518, 691

Mineral

content, 249

interaction, 441

nutrition, 441

requirements, 441

Minirhizotron, 292

Mixed prairie, 348

Moderate Resolution Imaging Spectroradiometer, 207

Molyneux, Russell J., 447

Monitoring, 61

Monsen, Stephen B., 299

Montagne, Cliff, 528

Moore, Kenneth J., 420
Mountain big sagebrush, 589

Mukherjee, A., 370

Mule deer, 269, 595

Multispectral, 152

Multivariate analysis, 330

Murray, L.W., 370

Muscio, Antonio, 122

Mutualism, 390

$\mathbf{N}$

Naeth, M.A., 704

Native

grasslands, 2

plants, 502

Natural resource accounting, 553

Ne'eman, G., 561

Neotyphodium, 390

Neutral detergent, 466

fiber, 641

Newman, Gregory J., 717

Nicholas, Mike, 382

Nitrate, 194

Nitrogen

addition, 284

availability, 400

Non-destructive sampling, 57

Non-native species, 307

Non-point source pollution, 356

North Dakota, 611

Northeastern zone, 537

Northern, 260

Bobwhite, 685

Great Plains, 656, 663

mixed grass prairie, 292

Noxious

brush and weeds, 208

weed, 502

Nudell, Dan J., 322

Nutrition, 409

Nutritional dynamics of 7 northern Great

Basin grasses, 640

Nutritional

ecology, 218

quality, 595

Nutritive quality of cholla cactus as affected by burning, The, 249

Nutritive value, 25

Nutritive value and aversion of honey mesquite leaves to sheep, 82

\section{o}

Observation: Long-term increases in mesquite canopy cover in a North Texas savanna, 171

Ocular estimation, 57

Odocoileus hemionus, 205

Odocoileus virginianus, 537

Oesophageal fistula, 582

Off-stream water, 648

Old World bluestem, 348

Olson, Bret E., 25

Olson, Richard A., 166, 699

Overstocking, 279
Ovis musimon, 239

Oxytropis lambertii, 265

Oxytropis sericea, 265

\section{$\mathbf{P}$}

Pachepsky, Yakov, 203

Paddock shape effects on grazing behavior and efficiency in sheep, 122

Panter, Kip E., 447

Particle size distribution, 194

Paschke, Mark W., 711

Pascopyrum, 674 smithii, 656, 663

Passage, 575

Pasture, 653

management, 490

Pastures, 546

Peláez, Daniel V., 617

Pelliza, Alicia, 330

Peoples, Alan D., 260

Perennial ryegrass, 474

Perevolotsky, Avi, 161, 561

Performance, 409

Period of stay, 39

Perryman, Barry L., 166, 699

Petersen, Joseph L., 603

Petersen, M.K., 249

Peterson, Regina, 106

Pfister, J.A., 431, 447

Phenology, 197

Phillips, Robert A., 603

Photography, 378

Physical and chemical comparisons between microphytic and non-microphytic soil seedbeds, Technical Note, 194

Physical plant defenses, 413

Pinchak, William E., 71, 553

Pinyon-juniper, 226, 518

Piptochaetium napostaense (Speg.) Hack., 617

Pisanu, Benoît, 239

Plant

density, 653

toxins, 447

Planting, 653

Platanthera praeclara, 611

Poa sandbergii, 641

Pogonomyrmex, 11

Point sample, 67

Point sampling for leaf area index in sagebrush steppe communities, 589

Poisonous plants, 265, 447, 494

Polyphenolics, 466

Population dynamics, 382

Populus tremuloides, 691

Practical measures for reducing risk of alfalfa bloat in cattle, 490

Prairie shrubland, 685

Prairie dog effects on harvester ant species diversity and density, 11

Precipitation, 31

Preference, 274 
Prescribed burning, 57, 553

Prescribed fire, 2, 362

Principles and practices for managing rangeland invasive plants, Invited Synthesis Paper, 502

Production, 243

Proposed method for determining shrub utilization using (LA/LS) imagery, A, 378

Prosopis, 171

Prosopis glandulosa, 82, 139

Prostrate summer cypress, 299

Protein, 622, 669

Provenza, Frederick D., 161, 431

Public lands, 314

Purshia tridentata, 269, 595

Quail, 260

Quantifying suitable habitat of the threatened western prairie fringed orchid, 611 Quilter, Mark C., 378

\section{$\mathbf{R}$}

Raats, J.G., 582

Racher, B.J., 254

Radiotelemetry, 537

Rainfall, 382

Rainfall simulation, 567

Ralphs, Michael H., 265, 447

Ranching, 107

Ranching motivations in 2 Colorado Counties, 314

Range condition, tenure, management, and bio-phyiscal relationships in Sonora, Mexico, 31

Range research: The second generation, 115

Range

caterpillar, 462

improvement, 561

sites, 528

text, 115

Rangeland, 152, 653

forage production, 206

health, 207

insects, 462

policy, 314

seeding, 139

Rayson, G.D., 370

Réale, Denis, 239

Reclamation, 307, 717

Recruitment intervals, 166

Redberry juniper canopy cover dynamics on western Texas rangelands, 603

Redeker, Eric J., 98

Redente, Edward F., 711, 717

Redmann, Robert E., 177

Reece, Patrick E., 126

Reed canarygrass, 474

Reed, Jess D., 466

Reeves, Matthew C., 207

Reflectance, 254
Reflectance and image characteristics of selected noxious rangeland species, 208

Regeneration, 382

Regression, 243

Regulations, 314

Rehabilitation, 144

Reid, Edward D., 413

Relationship between plant species diversity and grassland condition, 177

Remote sensing, 152, 202, 204, 206, 208 , 378,528

Remote sensing of range production and utilization, 206

Remote sensing of redberry juniper in the Texas rolling plains, 254

Renfrew, Rosalind B., 546

Renovation, 502

Repeated measures, 39

Research Observation: Cattle preference for Lambert locoweed over white locoweed, 265

Reseeding, 144

Resilience of prickly burnet to management in east Mediterranean rangelands, 561

Resource selection, 205

Response of central North American prairies to seasonal fire, The, Viewpoint,

Responses of elk and mule deer to cattle in summer, 205

Restoration, 197, 502, 717

Restoring degraded riparian meadows: Biomass and species responses, 284

Restoring tallgrass prairie species mixtures on leafy spurge-infested rangeland, 362

Revegetating spotted knapweed infested rangeland in a single entry, 144

Revegetation, 284, 396, 502

Review of toxic glycosides in rangeland and pasture forages, 494

Ribic, Christine A., 546

Richness, 307

Rinella, Matthew J., 52

Riparian areas, 132

Riparian plant communities, 210

Ritchie, Jerry C., 203

Robel pole, 57

Rodents, 191

Rogosic, Jozo, 161

Root-killing herbicide, 553

Rosenstock, Steven S., 226

Rotational grazing, 39, 546

Rotationally stocked beef cattle responses to daily and weekly residence, 39

Rowe, Helen Ivy, 314

Rumen, 239

microbes, 494

Ruminant diets, 441

Ruminants, 494

Running, Steven W., 207

Runoff, 567
RUSLE, 356

Russell, J.R., 184

Rutley, Bruce D., 218

S

Salix, 400

Salting, 115

Salve, Rohit, 44

Sarcopoterium spinosum, 561

Saskatchewan, 177

Satellite imagery, 152

Sawyer, J.E., 249

Scanning laser, 203

Schacht, Walter H., 126

Scott, Cody B., 274

Secondary compounds, 82

Sediment yield, 356

Seed, 191

banks, 292

care, 396

dispersal, 575

mixtures

survival, 575

Seed recovery and germination of reseeded species fed to cattle, 575

Seedbed, 139

Seeding, 717

Seedling

counts, 653

establishment, 144, 680, 699

Segarra, Eduardo, 409

Sell, Randall S., 322

Semi-arid rangeland, 98

Sequential sampling protocol for monitoring pasture utilization using stubble height criteria, 132

Sevi, Agostino, 122

Seyfried, Mark S., 152, 203, 589

Sharp-tailed grouse (Tympanuchus phasianellus) habitat, 126

Sheep grazing spotted knapweed and Idaho fescue, 25

Sheep, 669 loss rate, 15

Sheley, Roger L., 52, 144, 502

Shewmaker, Glenn E., 441

Shipley, Lisa A., 413

Short, R.E., 77

Shortgrass prairie, 11

Shrub, 269 encroachment, 171, 561

Shrubs, 161

Sieg, Carolyn Hull, 611

Silanikove, Nissim, 161

Similarity, 21

Similarity of diets, 330

Simple method for preparing reference slides of seed, A, Technical Note, 191

Simulation, 61

Sinuosity, 567

Sitanion hystrix, 641

Ski runs, 307

Smith, D.G., 582 
Smith, J.L., 356

Soil moisture, 210, 611

South Africa, 582

Southwestern U.S., 226

Space pattern, 122

Spatial modeling of rangeland potential vegetation environments, 528

Species

composition, 284

richness, 546

Species composition on reclaimed ski runs compared with unseeded areas, 307

Spines, 413

Spotted knapweed response to season and frequency of mowing, 52

Stability, 685

Standing crop, 89, 656 proportion, 71

State and transition model, 210

Statistical analyses of fluorometry data from chloroform filtrate of lamb feces, 370

Steer, 77

Stegelmeier, Bryan L., 447

Stem density, 567

Stewart, Alison, 396

Stipa

gynerioides Phil., 617

tenuis Phil., 617

thurberiana, 641

Stoddart, L. Charles, 15

Stream change analysis using remote sensing and geographic information systems (GIS), 204

Stream morphology, 204

Stringham, Tamzen K., 210

Structural anti-quality characteristics of range and pasture plants, 413

Structure, 518

Stuedemann, J.A., 474

Subsurface hydrology, 44

Succession, 226, 685, 691, 717

Supervised classification, 152

Supplemental polyethylene glycol influences preferences of goats browsing blackbrush, 161

Suppression of annual bromes impacts rangeland: Vegetation responses, 656

Surface

cover, 356

roughness, 184, 356, 711

Survey, 314

Survival, 674

Sustainable agriculture, 107

Svejcar, Tony J., 691

Swainsonine, 265

Swanson, Jr., Louis E., 314

Sward structure, 177

\section{$\mathbf{T}$}

Tall fescue, 474

Tallgrass prairie, 390,611

Tannins, 161
Taylor, Jr., Charles A., 274

Teague, W. Richard, 71, 553, 680

Technique, 191

Technology

adoption, 630

transfer, 107

Thermal

cover, 537

death point, 617

Thinopyrum, 674

Thomas, David R., 210

Thomas, Tamiko, 243

Thompson, F.N., 474

Threatened plant, 611

Threshold

friction velocity, 711

wind speed, 711

Thurow, Thomas L., 98

Time change analysis, 204

Tisone, G., 370

Titus, Christopher H., 161

Tiver, Fleur, 382

Topography, 184

Townsend II, Darrell E., 260

Toxic plants, 431

Toxicosis, 274

Toxins, 409

Tracked vehicle impacts to vegetation structure and soil erodibility, 711

Triticeae, 674

Trlica, M.J., 356, 567

Tueller, Paul T., 206

Turner, David L., 132

Two-way Indicator Species Analysis (TWINSPAN), 177

\section{$\mathbf{U}$}

Ueckert, Darrell N., 603, 630

Undegraded intake protein, 233

Unsworth, James W., 595

Upland erosion under a simulated most damaging storm, 356

Upland game, 260

Uplands, 243

Urban development, 314

Urine, 704

Utilization, 25, 206, 338

\section{$\mathrm{V}$}

Valentine, David W., 400

Van Ommeren, Ron J., 307

Van Riper III, Charles, 226

Van Zee, Justin, 61

Variations in soil moisture content in a rangeland catchment, 44

Vegetation, 152, 203

inventory, 378

mapping, 528

measurement, 67

seasonality, 207

structural, 685

Vegetation and water yield dynamics in an
Edwards Plateau watershed, 98

Vermeire, Lance T., 57

Vinton, Mary Ann, 390

Vogel, Kenneth P., 390, 653, 674

Volesky, Jerry D., 126

\section{W}

Waichler, Wendy Sims, 518

Waldron, Daniel F., 603

Wall, Travis G., 691

Wallander, Roseann T., 25

Warm-season grasses, 362

Water quality, 356,648

sources, 537

tables, 284

efficiency (WUE), 622

Water year, 243

Weber, Keith T., 21, 202

Weed, 25

control, 52

management, 144

Welling, G. Robert, 338

Wester, David B., 89

Wetland, 611

Whisenant, S.G., 680

White clover, 39

Wiedemann, H.T., 138

Wildfire, 2, 115

Wildlife, 21

habitat, 67

Willems, Priscila, 330

Williams, Stephen A., 400

Williams, Stephen E., 611

Willow, 400

Wind tunnels, 711

Winslow, Jerome C., 207

Wisdom, Michael J., 205

Wittenberg, K.M., 575

Wolken, Paige M., 611

Woody

plants, 685

weeds, 382

Wu, X. Ben, 98, 171, 603

Wyoming big sagebrush, 589

$\mathbf{X}$

Xenon fluorometry, 371

\section{$\mathbf{Y}$}

Yang, C., 254

Yellow fat, 39

Yonatan, R., 561

Young, James A., 115, 194, 26 


\section{Journal of Range Management Manuscript Submission and Copyright Release Form}

This form must be completed and submitted with the manuscript. If the manuscript is not accepted for publicatic this affidavit shall have no legal effect and may be considered null and void.

\section{Please Print}

1. Manuscript Title:

2. Name and Address of Correspond Author:

Name Address

Telephone ( )

E-Mail Fax \#( )

3. Membership

I (we) affirm that at least one of the authors is a current member of the Society for Range Management.

$$
\text { Yes }
$$
No

Name of Member:

4. Assurance of Content:

I (we) have read this manuscript and I (we) affirm that the content of this manuscript or a major portion thereof has not be published in a refereed journal, and it is not being submitted for publication elsewhere.

\section{Section Preference:}

ㄱ Plant Physiology

$\square$ Animal Ecology

$\square$ Plant Ecology

$\neg$ Plant-Animal Interactions

$\checkmark$ Grazing Management

$\checkmark$ Animal Physiology $\square$ Improvements

$\square$ Reclamation

$\square$ Soils

$\square$ Hydrology

$\square$ Economics

$\square$ Measurement/Sampling 


\section{Publication Costs:}

The current charge for publication is $\$ 80$ per printed page in the Journal for members for the first 3 printed pages. Page 4 and beyond is $\$ 100$ /page. For nonmembers the charge is $\$ 100$ /page. Reprints may be ordered. The following agency or individual will be responsible for publication costs:

Name

Address

\section{Copyright Release:}

Copyright laws make it necessary for the Society to obtain a release from authors from all material published. To this end, we ask you to grant us all rights, for your article.

Whereas the Society is undertaking to publish the Journal of Range Management, of which the undersigned is the author of one or more parts, the author grants and assigns exclusively to the Society for its use any and all rights of whatsoever kind or nature now or hereafter protected by the copyright laws (common or statutory) of the United States and all foreign countries in all languages in and to above-named article, including all subsidiary rights. The Society, in turn, grants to the author(s) the rights or republication in any book of when he or she is author or editor, subject only to giving proper credit in the book to the original Journal publication of the article by the Society. Each author agrees that the material furnished for the Journal has been be published elsewhere. The corresponding author will be given an opportunity to read and correct the edited manuscript as page proofs, but if the author(s) fails to return page proofs to the production editor of the Journal within the time specified by the editor, production and publication may proceed with the author's approval of the edited manuscript.

The author(s) will receive no monetary return from the Society for the use of material contained in the manuscript.

I (we) agree to the foregoing terms:

Author (print or type)

Signature

Author (print or type)

Signature

Author (print or type)

Signature

Author (print or type)

Signature

I (we) agree to the foregoing terms except item 7. I (we) am unable to sign a copyright release for reasons stated below:
Date

Citizen of (country

Date

Citizen of (country

Date

Citizen of (country

Date

Citizen of (country

l(we) agree to the foregoing terms except item 7.1 (we) an unable to sign a copynght relcase ior reasons scaced oelow:

Send this form and 4 copies of the manuscript on line-number paper to:

$$
\text { Editor }
$$

Journal of Range Management

7820 Stag Hollow Road

Loveland, Colorado 80538 


\section{Eligibility}

The Journal of Range Management is a publication for reporting and documenting results of original research and selected invitational papers. Previously published papers are unacceptable and will not be considered for publication. Exceptions to this criterion are research results that were originally published as department research summaries, field station reports, abstracts of presentations, and other obscure and nontechnical handout publications. Manuscripts submitted to the JRM are the property of the Journal until published or released back to the author(s). Manuscripts may not be submitted elsewhere while they are being considered for this journal. Papers not accepted for publication are automatically released to the authors.

\section{Kinds of Manuscripts}

Journal Articles report original findings in Plant Physiology, Animal Nutrition, Ecology, Economics, Hydrology, Wildlife Habitat, Methodology, Taxonomy, Grazing Management, Soils, Land Reclamation (reseeding), and Range Improvement (fire, mechanical chemical). Technical Notes are short articles (usually less than 2 printed pages) reporting unique apparatus and experimental techniques. By invitation of the Editorial Board, a Review or Synthesis Paper may be printed in the journal. Viewpoint articles or Research Observations discussing opinion or philosophical concepts regarding topical material or observational data are acceptable. Such articles are identified by the word viewpoint or observations in the title.

\section{Manuscript Submission}

Contributions are addressed to the Editor, Gary Frasier, Journal of Range Management, 7820 Stag Hollow Road, Loveland, Colorado 80538. Manuscripts are to be prepared according to the instructions in the Journal's Handbook and Style Manual. If the manuscript is to be one of a series, the Editor must be notified. Four copies of the complete manuscript, typed on paper with numbered line spaces are required. Authors may retain original tables and figures until the paper is accepted, and send good quality photocopies for the review process. Receipt of all manuscripts is acknowledged at once, and authors are informed about subsequent steps of review, approval or release, and publication.

Manuscripts that do not follow the directives and style in Journal handbook will be returned to the authors before being reviewed. A manuscript number and submission date will be assigned when the paper is received in the appropriate format.

\section{Manuscript Review}

Manuscripts are forwarded to an Associate Editor, who usually obtains 2 or more additional reviews. Reviewers remain anonymous. These reviewers have the major responsibility for critical evaluation to determine whether or not a manuscript meets scientific and literary standards. Where reviewers disagree, the Associate Editor, at his discretion, may obtain additional reviews before accepting or rejecting a manuscript. The Associate Editor may also elect to return to the author those manuscripts that require revision to meet format criteria before the Journal review.

The Associate Editor sends approved manuscripts, with recommendations for publication, to the Editor, who notifies the author of a projected publication date. Manuscripts found inappropriate for the JRM are released to the author by the Associate Editor. Manuscripts returned to an author for revision are returned to the Associate Editor for final acceptability of the revision. Revisions not returned within 6 months, are considered terminated. Authors who consider that their manuscript has received an unsatisfactory review may file an appeal with the Editor. The Editor then may select another Associate Editor to review the appeal. The Associate Editor reviewing the appeal will be provided with copies of an correspondence relating to the original review of the manuscript. If the appeal is sustained, a new review of the manuscript may be implemented at the discretion of the Editor.

Authors should feel free to contact the Associate Editor assigned to their manuscript at any stage of the review process: to find out where the paper is in the process; to ask questions about reviewer comments; to ask for clarification or options if a paper has been rejected.

\section{Page Proofs}

Page proofs are provided to give the author a final opportunity to make corrections of errors caused by editing and production. Authors will be charged when extensive revision is required because of author changes, even if page charges are not assessed for the article. One author per paper will receive page proofs. These are to be returned to the Production Editor, 445 Union Blvd., Suite 230, Lakewood, Colorado 80228, within 48 hours after being received. If a problem arises that makes this impossible, authors or their designates are asked to contact the Production Editor immediately, or production and publication may proceed without the author's approval of his edited manuscript.

\section{Page Charges and Reprint Orders}

Authors are expected to pay current page charges. Since most research is funded for publication, it will be assumed that the authors are able to pay page charges unless they indicate otherwise in writing, when submitting a manuscript. When funds are unavailable to an author, no page charges will be assessed. Only the Editor will have knowledge of fund status of page charges; the Associate Editors and reviewers will accept or reject a manuscript on content only.

An order form for reprints is sent to one author with the page proofs. Information as to price and procedure are provided at that time. The minimum order is 100; no reprints are provided free of charge.

\section{Basic Writing Style}

Every paper should be written accurately, clearly, and concisely. It should lead the reader from a clear statement of purpose through materials and methods, results, and to discussion. The data should be reported in coherent sequence, with a sufficient number of tables, drawings, and photographs to clarify the text and to reduce the amount of discussion. Tables, graphs, and narrative should not duplicate each other.

Authors should have manuscripts thoroughly reviewed by colleagues in their own institution and elsewhere before submitting them. Peer review before submission insures that publications will present significant new information or interpretation of previous data and will speed $J R M$ review process.

Particular attention should be given to literature cited: names of authors, date of publication, abbreviations or names of journals, titles, volumes, and page numbers.

It is not the task of Associate Editors or Journal reviewers to edit poorly prepared papers or to correct readily detectable errors. Papers not properly prepared will be returned to the author. 